VIVIAN BRADASCHIA CORRÊA

\title{
ESTUDO DA OSTEOCLASTOGÊNESE E DA REMODELAÇÃO ÓSSEA DURANTE A FORMAÇÃO E ERUPÇÃO DE MOLARES DE RATOS TRATADOS COM BISFOSFONATOS
}

Tese apresentada ao Programa de Pós Graduação em Biologia Celular e Tecidual do Instituto de Ciências Biomédicas da Universidade de São Paulo, para obtenção do título de Doutor em Ciências.

São Paulo 


\section{VIVIAN BRADASCHIA CORRÊA}

\section{ESTUDO DA OSTEOCLASTOGÊNESE E DA REMODELAÇÃO ÓSSEA DURANTE A FORMAÇÃO E ERUPÇÃO DE MOLARES DE RATOS TRATADOS COM BISFOSFONATOS}

Tese apresentada ao Programa de Pós Graduação em Biologia Celular e Tecidual do Instituto de Ciências Biomédicas da Universidade de São Paulo, para obtenção do título de Doutor em Ciências.

Área de concentração: Biologia Celular e Tecidual

Orientador: Prof. Dr. Victor Elias Arana-Chavez

Versão Corrigida: Versão original se encontra arquivada no serviço de comuicações do ICB.

São Paulo 
DADOS DE CATALOGAÇÃO NA PUBLICAÇÃO (CIP)

Serviço de Biblioteca e Informação Biomédica do

Instituto de Ciências Biomédicas da Universidade de São Paulo

C reprodução total

Corrêa, Vivian Bradaschia.

Estudo da osteoclastogênese e da remodelação óssea durante a formação e erupção de molares de ratos tratados com bisfosfonatos / Vivian Bradaschia Corrêa. -- São Paulo, 2011.

Orientador: Victor Elias Arana-Chavez.

Tese (Doutorado) - Universidade de São Paulo. Instituto de Ciências Biomédicas. Departamento de Biologia Celular e do Desenvolvimento. Área de concentração: Biologia Celular e Tecidual. Linha de pesquisa: Biologia Oral.

Versão do título para o inglês: Study of the osteoclastogenesis and bone remodeling during the formation and eruption of molars of bisphosphonate-treated rats

Descritores: 1. Erupção dentária 2 2. Osteoclasto 3. Reabsorção óssea alveolar 4. Odontogênese 5 . Imunocitoquímica 6. Microscopia eletrônica I. Arana-Chavez, Victor Elias II. Universidade de São Paulo. Instituto de Ciências Biomédicas. Programa de Pós-Graduação em Biologia Celular e Tecidual III. Título. 


\section{UNIVERSIDADE DE SÃO PAULO \\ INSTITUTO DE CIÊNCIAS BIOMÉDICAS}

Candidato(a):

Tese:

Orientador(a):
Vivian Bradaschia Corrêa.

Estudo da osteoclastogênese e da remodelação óssea durante a formação e erupção de molares de ratos tratados com bisfosfonatos.

Victor Elias Arana-Chavez.

A Comissão Julgadora dos trabalhos de Defesa da Tese de Doutorado, em sessão pública realizada a considerou
( ) Aprovado(a)
( ) Reprovado(a)

Examinador(a):

Assinatura:

Nome:

Instituição:

Examinador(a): Assinatura:

Nome:

Instituição:

Examinador(a): Assinatura:

Nome:

Instituição:

Examinador(a): Assinatura:

Nome:

Instituição:

Examinador(a): Assinatura:

Nome:

Instituição: 


\begin{tabular}{|l|l|}
\hline UNIVERSIDADE DE SÃO PAULO \\
INSTITUTO DE CIÊNCIAS BIOMÉDICAS \\
Cidade Universitária "Armando de Salles Oliveira" \\
Av. Prof. Lineu Prestes, 2415 - Cep. 05508-900 São Paulo, SP - Brasil \\
Telefone :(55) (011) 3091.7733 - telefax : (55) (011)3091-7438 \\
e-mail: cep@icb.usp.br \\
COMISSÃO DE ÉTICA EM EXPERIMENTAÇ̃̃O ANIMAL
\end{tabular}

Decl. CEEA.016/07

\section{E C L A A C Ã O}

Em adendo ao Certificado 23/03/CEEA, aprovo a inclusão da aluna ViviAN BRADASCHIA CORRÊA ao projeto: "Estudo Imunocitoquímico da Participação de Proteínas e Peptídeos do Esmalte nas Interações Epitélio-Ectomesenquimais e Durante o Início da Mineralização de Germes Dentários de Ratos Normais e Tratados com Bisfosfonatos" de responsabilidade da aluna LuCIANA FERREIRA MASSA, para uso da espécie animal utilizado e métodos semelhantes, mediante solicitação do Prof. Dr. Victor Elias Arana-Chavez, responsável pela linha de Pesquisa.

São Paulo, 03 de maio de 2007.

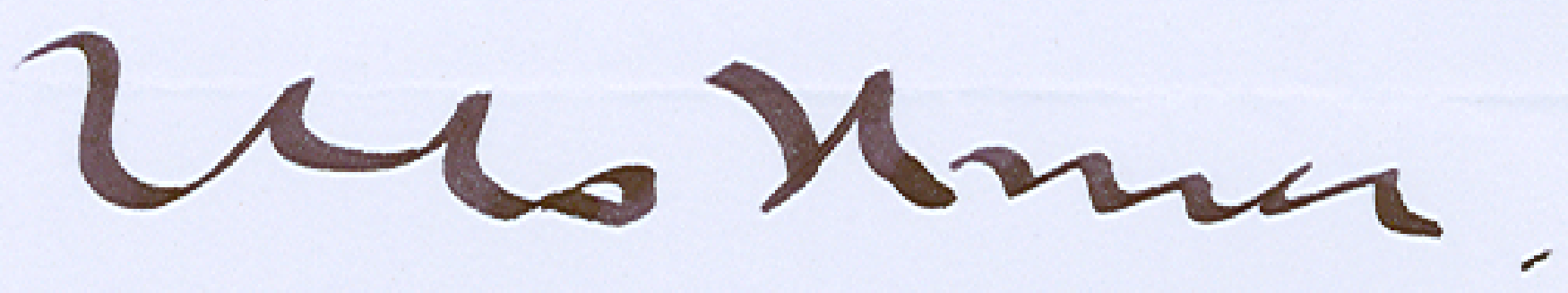

Prof. Dr. WOTHAN TAVARES DE LIMA

Coordenador da CEEA- ICB/USP 
A DEUS, QUE POR SUA GRAÇA ME CONCEDEU A OPORTUNIDADE DE REALIZAR ESTE SONHO...

...AOS MEUS MARAVILHOSOS PAIS, SUZANA E PAULO TRAJANO, FONTES DE PACIÊNCIA E AMOR INFINITOS, QUE SEMPRE CONFIARAM NAS MINHAS ESCOLHAS E NÃO MEDIRAM ESFORÇOS EM PROL DA MINHA FORMAÇÃO...

...AO MEU QUERIDO NAMORADO, COMPANHEIRO E AMIGO SHANON, PRESENTE DURANTE TODO O PERCURSO DESTA MINHA JORNADA... 


\section{AGRADECIMENTOS}

Em especial, agradeço ao meu grande amigo e orientador, Prof. Dr. Victor Elias Arana-Chavez, por todas as oportunidades a mim concedidas, pela confiança no meu potencial, por seu exemplo de dedicação à docência e à ciência. Admiro profundamente sua competência, ética e profissionalismo, que o tornaram este pequisador mundialmente respeitado no âmbito da Biologia Oral. Sou, com muito orgulho, "cria" de seu laboratório, e espero continuar crescendo e aprendendo muito ao seu lado! Muito obrigada por tudo!

À minha amiga e tutora durante meus primeiros anos de Iniciação Científica no extinto Laboratório de Biologia dos Tecidos Mineralizados, Luciana Ferreira Massa. Obrigada pelo seu exemplo de competência.

À FAPESP (Processo 2006/60094-5) e à CAPES (Processo BEX 2389-09-6) pelo apoio financeiro.

Aos professores do Departamento de Biologia Celular e do Desenvolvimento Jarbas Arruda Bauer, Alison Colquhoun, Anselmo Moriscot, Patricia Gama, Glaucia Santelli, Ciro da Silva, Edna Kimura, Dânia Hamassaki, Fábio Siviero e Maria Inês Borella. Vocês foram muito importantes na minha formação.

À secretária do Programa de Pós Graduação em Biologia Celular e Tecidual, Celiana Marchiori, pela competência e disponibilidade em ajudar durante os momentos "burocráticos" da minha Pós Graduação.

À Tereza Cristina Souto Mayor, bibliotecária do Instituto de Ciências Biomédicas, pela atenciosidade durante a formatação deste trabalho.

Aos meus colegas dos tempos de Laboratório de Biologia dos Tecidos Mineralizados, Silvia João, Denise de La Fuente, Cristina Jimenez-Pellegrin, Daniela Janones, Newton Maciel Oliveira, Lucienne Bonafé, Jaqueline de Carvalho, Márcio Cajazeira e Elizabeth Martinez, Natasha Mateus e Sabrina Tessi, pela convivência 
sempre divertida e descontraída, especialmente na hora do café e nas imunocitoquímicas.

À querida técnica do Laboratório de Biologia dos Tecidos Mineralizados, Fernanda Ângela Correia Barrence, pela extrema competência e dedicação ao seu trabalho.

Às colegas do Laboratório de Biologia Oral (LBO), Fernanda Yamamoto, Tatiani Donato, Lorraine Braga, Luana de Campos, Cláudia Rothbarth, Eloiza de Rezende e Natasha Mateus. Vocês são companheiras incríveis, é muito bom trabalhar ao lado de vocês! Vocês todas são muito especiais!

À minha pupila Taís Carvalho de Oliveira por, além da parceria nos experimentos, sua companhia e amizade.

Aos "mascotes" Giovanna de Castro, Lucas Ambrósio e Caroline Arruda, alunos de Iniciação Científica do LBO. A presença de vocês no laboratório traz muita alegria a todos.

À secretária do LBO Edeleine Mário, por ser sempre prestativa e disposta a me ajudar na correria do dia a dia, por cuidar tão bem de todos nós no laboratório, e pelo cafezinho especial sempre nos momentos certos!

Aos colegas do Laboratório de Bioquímica Oral da FOUSP Danielle Carvalho, Ana Carolina Romero e Flavia Ibuki, aos alunos de Iniciação Juliana e Felipe, ao técnico Douglas Nadal e à Profa. Alyne Simões.

Às secretárias do Departamento de Materiais Dentários da FOUSP, Elidamar Guimarães e Rosa Cristina Nogueira, pelo carinho e alegria contagiantes ao me receberem cada vez que eu visito o departamento.

Aos colegas de Pós Graduação do Departamento de Biologia Celular e do Desenvolvimento do ICB, Ana Paula Zen Petisco Fiore, Raquel Bernardeth de Almeida, Juliano Andreoli Miyake, Renado Mayrinck Salgado, Jônatas Bussador do Amaral, Luciana Harumi Osaki, Ariane Kasai, Adam Arai, Marina Costa Rosa, 
Alexandre Borbely, Rodolfo Favaro, Evandro Niero, Murilo Vieira Geraldo, Alex Shimura Yamashita, César Fuziwara e Chayrra Chehade. Em especial à Ana e à Raquel, que me apoiaram muito durante a pós.

Aos técnicos do Departamento de Biologia Celular e do Desenvolvimento, Cleusa Pelegrini, Emília Ribeiro e Marley Januário, pela ajuda em momentos importantes durante meus experimentos.

Aos técnicos do setor de Microscopia Eletrônica do Instituto de Ciências Biomédicas, Edson Rocha de Oliveira, pelo excelente trabalho nas fotografias, Gaspar Ferreira de Lima, pelo impecável trabalho de ultramicrotomia e ao Gerson Batista da Silva (in memorian), que esteve ao meu lado durante meus primeiros momentos de manejo do microscópio eletrônico de transmissão.

Ao técnico Roberto Cabado Modia, pela atenciosidade durante a captura das imagens no microscópio confocal de varredura a laser, e pelas dicas sobre o encantador mundo da computação gráfica.

Aos técnicos do biotério de experimentação animal do Departamento de Biologia Celular e do Desenvolvimento, Claudio Cabado Modia e Fernando Gonçalves de Araujo, por cuidarem com tanto carinho dos nossos animais, e por proporcionarem a eles um ambiente saudável e organizado.

Aos meus colegas do curso de graduação em Odontologia, a turma 94 da FOUSP.

À minha amada irmã Marina Bradaschia Corrêa Abdul Ghani, que sempre me acompanhou e apoiou. Aos meus sobrinhos Gabriel e Samara, que me fizeram descobrir o que é amar incondicionalmente. Ao meu cunhado Daniel Abdul Ghani, pela amizade e apoio.

À minha família Bradaschia. Minha querida avó Lais Bradaschia, minhas tias Silvana, Simone e Regina Bradaschia, meu querido tio Eduardo Bradaschia e minhas primas Juliana e Fernanda Bradaschia, pelo incentivo, confiança e 
incansável torcida. Obrigada por compreenderem minha ausência em tantos eventos.

À minha família Corrêa, especialmente à minha linda avó Nair, meus tios Ana, Carmem Silvia, Fernando e Ligia e primos. À minha querida prima e amiga Karin Corrêa Scheffer, por compartilharmos juntas as "agonias" do final de nossos doutorados. Obrigada por compreenderem minha ausência em tantos eventos também.

À família Leite Pereira, Dona Chizue, Sr. Tarquínio, Tio Beto e meus queridos cunhados Tatihana, Thelma, Sinuhe e Simiran e concunhados Daniel, Luis Eduardo, Patrícia e Sara. A torcida e apoio de vocês foram fundamentais.

Ao Shanon Leite Pereira, por me acompanhar durante todos esses anos da Pós Graduação em experimentos durante finais de semana e feriados. Muito obrigada pela companhia, apoio e carinho.

Aos Donatinhos, ETs, e demais ratos e camundongos que doaram suas vidas para que este trabalho pudesse se concluir, eu dedico meu profundo respeito e gratidão. 
Gostaria de agradecer ao Dr. Lexie Shannon Holliday, meu co-orientador durante o Doutorado Sanduíche na Universidade da Flórida, por me receber em seu laboratório e me proporcionar a oportunidade de aprender a cultivar osteoclastos. Seu empenho e entusiasmo na busca da compreensão da função destas células, bem como na busca de mecanismos eficazes para controlá-las, me motivaram e inspiraram muito.

(I would like to acknowledge Dr. Lexie Shannon Holliday, my co-mentor during my sandwich doctorate period at the University of Florida College of Dentistry, for hosting me in his laboratory and allowing me the opportunity to learn how to cultivate osteoclasts. His determination and enthusiasm in the quest for the comprehension of osteoclast resorptive function, as well as an accurate mechanism for controlling it, have motivated me.)

Gostaria também de agradecer ao Edgardo Toro, por ter me ajudado em todos os momentos, do primeiro ao último dia, me ensinado todo o funcionamento do Holliday Lab, e por ter se tornado um grande amigo.

(I would also like to acknowledge Edgardo Toro for his help from my first to my last day in Gainesville, for showing me how everything works at the Holliday Lab and for becoming a great friend.)

Finalmente, agradeço à Leandra Dopazo e à Teresa Cristina Cunha, brasileiras em Gainesville, por todo o apoio e amizade durante a minha estadia e por me fazerem sentir que não estava tão longe de casa. 
vá até onde puder ver; quando lá chegar poderá ver ainda mais longe.

(Goethe) 


\section{Resumo}

Bradaschia-Correa, V. Estudo da osteoclastogênese e da remodelação óssea durante a formação e erupção de molares de ratos tratados com bisfosfonatos. [Tese (Doutorado em Biologia Celular e Tecidual)]. São Paulo: Instituto de Ciências Biomédicas, Universidade de São Paulo, 2011.

A erupção dentária depende de uma coordenada interação entre o germe dentário e o tecido ósseo da cripta que o envolve. Para que seja formada a via eruptiva, a reabsorção da porção oclusal da cripta óssea por osteoclastos é indispensável. Os bisfosfonatos são drogas com reconhecida capacidade de inibir a atividade clástica e foram empregados no presente estudo a fim de interferir no tecido ósseo da cripta alveolar durante a formação e erupção de molares de ratos. Doses diárias dos bisfosfonatos alendronato ou etidronato de 2,5 e $8 \mathrm{mg} / \mathrm{kg}$, respectivamente, foram administradas a ratos recém nascidos. Os controles foram injetados com solução salina. Nos períodos de 4, 8, 14, 21 e 28 dias, as maxilas foram fixadas em $2,5 \%$ de formaldeído $+2 \%$ de glutaraldeído, $4 \%$ de formaldeído $+0,1 \%$ de glutaraldeído ou fixador Zamboni, descalcificadas em EDTA a 4,13\% e processadas para análise em microscopias de luz, eletrônica de transmissão e confocal, histoquímica TRAP, imunocitoquímica para OPN, BSP, RANK, RANKL e OPG. Alguns espécimes não foram descalcificados para análise em microscopia eletrônica de varredura, ou congelados em nitrogênio líquido para extração e análise e da expressão de proteínas por Western Blotting. O etidronato ocasionou alterações no metabolismo ósseo da cripta que resultaram no atraso da erupção e da formação radicular em relação ao controle. $O$ alendronato aumentou o número de osteoclastos no osso alveolar, porém a maioria apresentou estado latente, o que diminuiu a reabsorção óssea da cripta ao redor do germe dentário e impediu a erupção dos molares e a formação radicular. A expressão de RANKL, molécula ativadora dos osteoclastos, durante o início do processo eruptivo, diminuiu em comparação ao controle. Com a diminuição da remodelação óssea, o tecido apresentou distribuição de OPN e BSP típica de osso primário. Os resultados demonstram que a reabsorção óssea é importante em todos os pontos da cripta e não apenas em sua porção oclusal durante a formação da via eruptiva, para que a formação e erupção dentária ocorram adequadamente.

Palavras Chave: Erupção dentária. Reabsorção óssea alveolar. Odontogênese. Osteoclastos. Microscopia Eletrônica. Imunocitoquímica. 


\begin{abstract}
Bradaschia-Correa, V. Study of the osteoclastogenesis and bone remodeling during the formation and eruption of molars of Bisphosphonate-treated rats. [Ph.D. thesis (Cell and Tissue Biology)]. São Paulo: Instituto de Ciências Biomédicas, Universidade de São Paulo, 2011.

Tooth eruption depends on coordinated interactions between the tooth germ and the surrounding bony crypt. The formation of the eruptive pathway requires the resorption of the occlusal portion of the bony crypt by osteoclasts. The bisphosphonates are drugs with known capability to inhibit clastic activity, and were employed in the present study with the aim of interfering in the alveolar bony crypt during the formation and eruption of rat molars. Daily alendronate or etidronate 2.5 and $8 \mathrm{mg} / \mathrm{kg}$ doses, respectively, were administered to newborn rats. The controls were injected with saline solution. At 4, 8, 14, 21 and 28 days, the maxillae were fixed in $2.5 \%$ formaldehyde $+2 \%$ glutaraldehyde, $4 \%$ formaldehyde $+0,1 \%$ glutaraldehyde or Zamboni's fixative, decalcified in $4.13 \%$ EDTA and processed for light, confocal and transmission electron microscopy analyzes, TRAP histochemistry, and immunocytochemistry for OPN, BSP, RANK, RANKL and OPG. Some specimens were left undecalcified for scanning electron microscopy analyzes, or frozen in liquid nitrogen for protein extraction and Western Blotting protein expression analyzes. Etidronate occasioned alterations in the alveolar bony crypt metabolism that resulted in the delay of tooth eruption. Alendronate increased osteoclast number in the alveolar bone; however, most of them were latent, which decreased the resorption of the bony crypt surrounding the tooth germ and impeded the eruption and root formation of the molars. The expression of RANKL, an osteoclast-activating molecule, was decreased. The inhibition of the bone remodeling resulted in typical primary bone OPN and BSP labeling pattern. These results demonstrate that bone resorption at the entire surface of the crypt, and not only during the eruptive pathway formation, is crucial for adequate tooth eruption and formation.
\end{abstract}

Key words: Tooth eruption. Alveolar bone resorption. Odontogenesis. Osteoclast. Electron microscopy. Immunocytochemistry. 


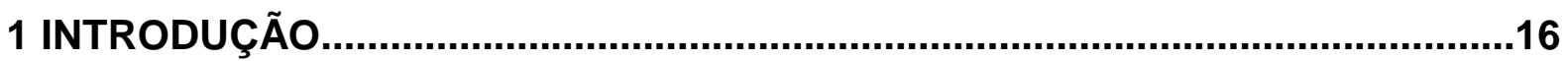

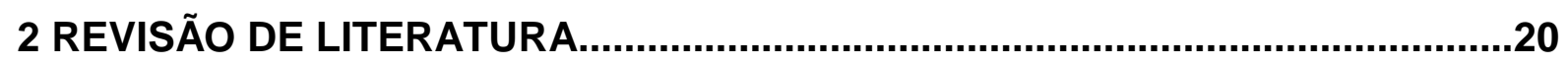

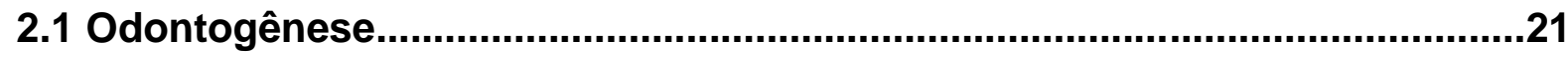

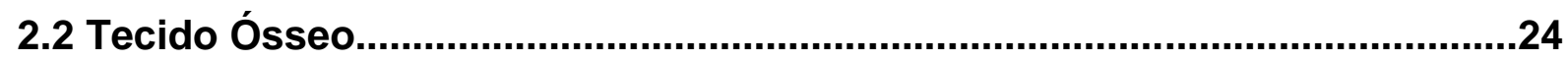

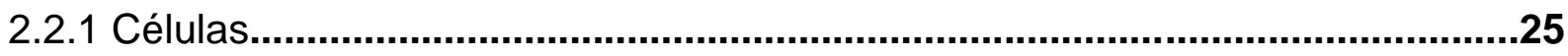

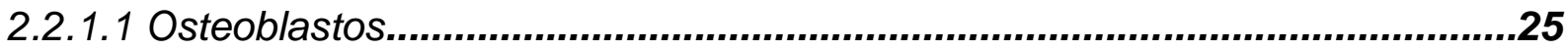

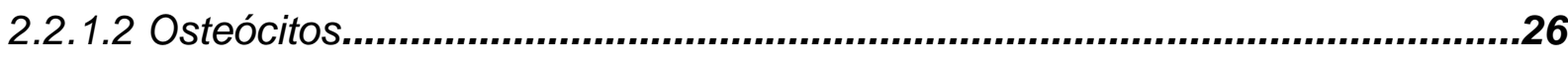

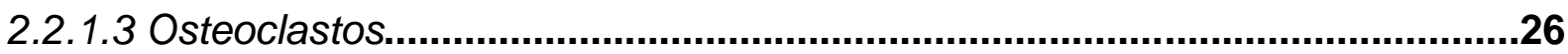

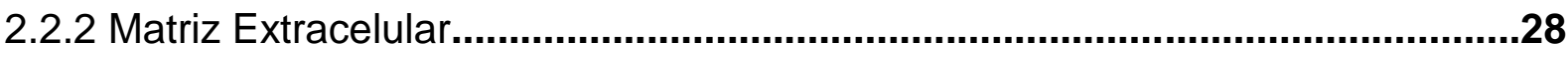

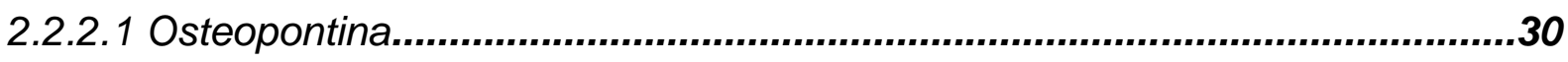

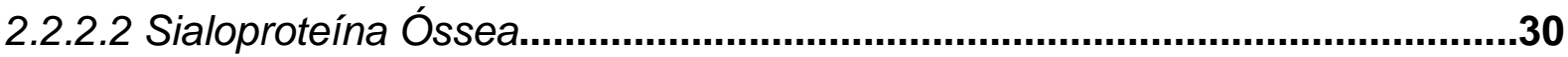

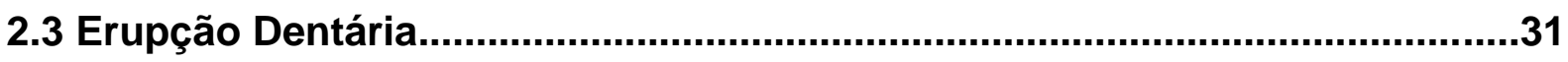

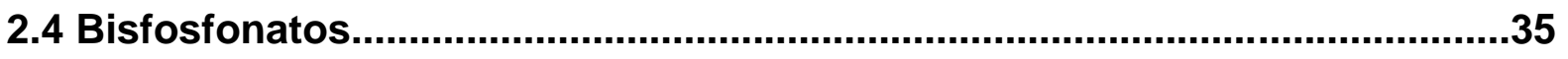

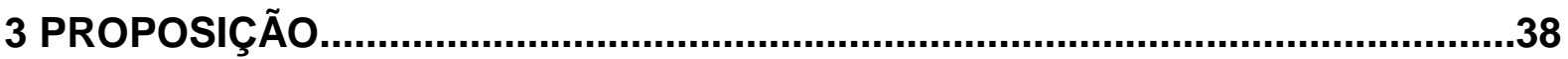

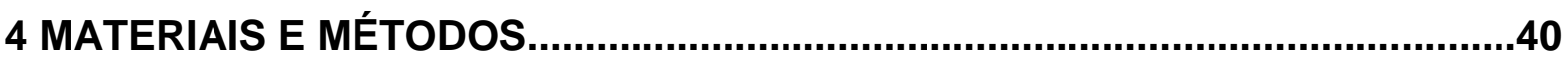

4.1 Tratamento dos animais com bisfosfonatos..................................................

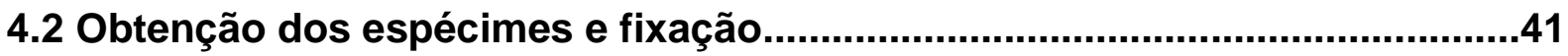

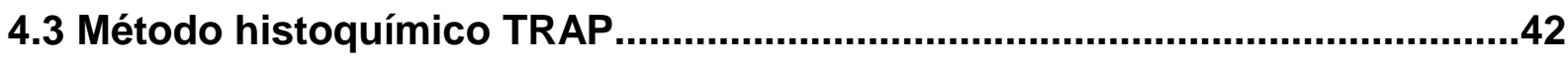

4.4 Microscopia eletrônica de varredura...................................................................43

4.5 Microscopia eletrônica de transmissão - morfologia......................................43

4.6 Imunocitoquímica pós inclusão com ouro coloidal.........................................44

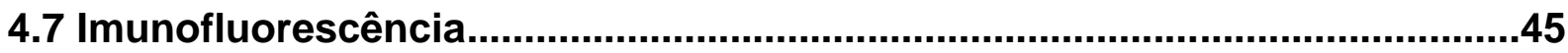

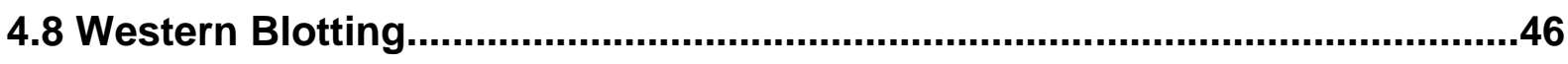

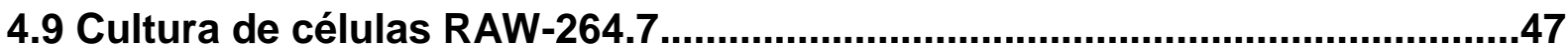

4.10 Cultura de células da medula óssea de camundongos................................48

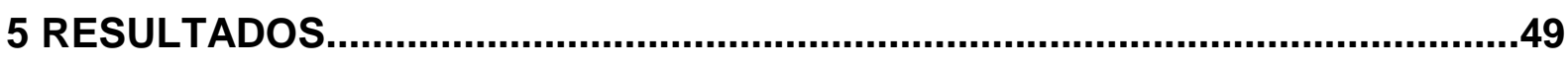

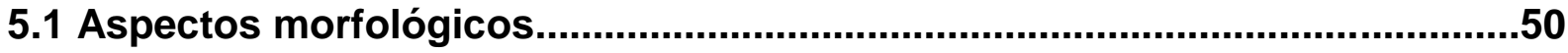




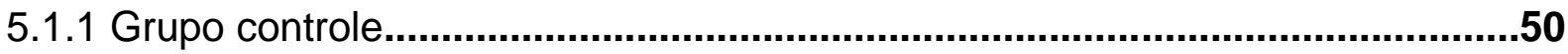

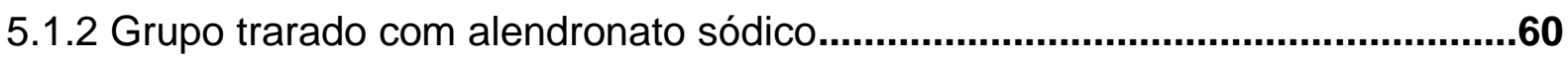

5.1.3 Grupo tratado com etidronato.....................................................................70

5.1.4 Análise das células TRAP positivas................................................................78

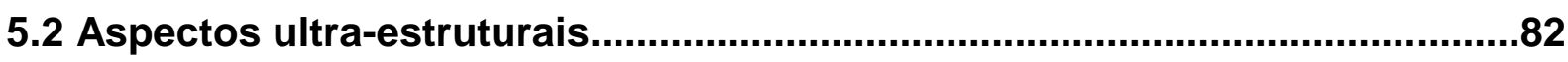

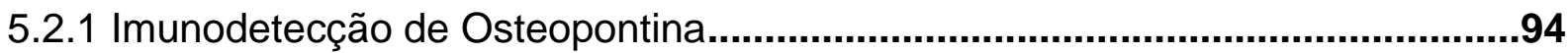

5.2.2 Imunodetecção de Sialoproteína Óssea......................................................96

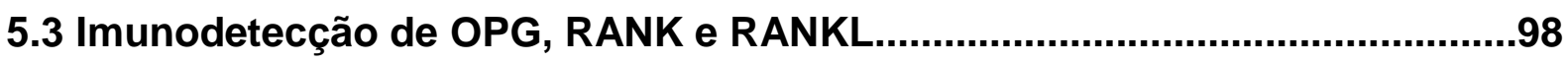

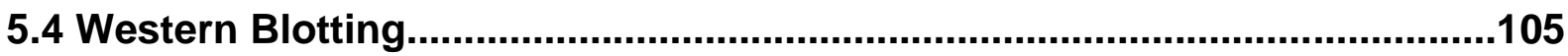

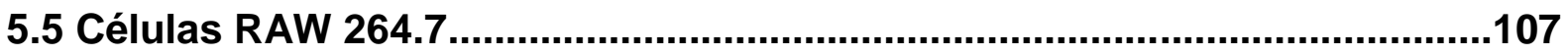

5.6 Células da medula óssea de camundongos................................................109

5.6.1 Análise dos discos de osso em MEV...........................................................111

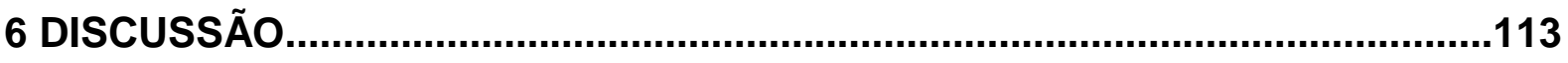

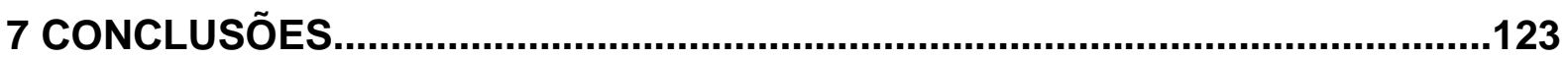

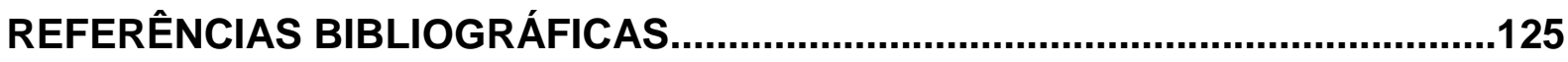

ANEXO 1 (Effects of alendronate on tooth eruption and molar root formation in

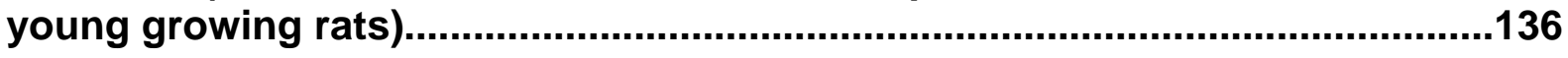

ANEXO 2 (Clastic Cells: Mineralized tissue resorption in health and

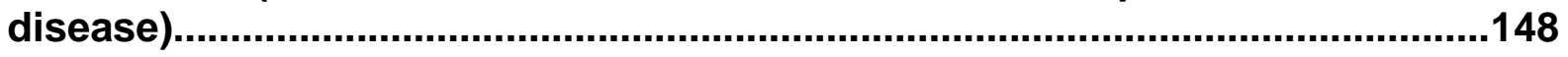


1 INTRODUÇÃO 
A erupção dentária é um evento parte do contexto do desenvolvimento craniofacial. Seu acontecimento depende de uma coordenada interação entre o dente em desenvolvimento e o tecido ósseo da cripta que o envolve, consistindo num dos eventos mais intrigantes da biologia oral.

A erupção dentária é classicamente dividida em cinco etapas, de acordo com a posição do dente. A primeira etapa, movimentação preeruptiva, consiste em uma discreta movimentação resultante do desenvolvimento do germe dentário em fase de coroa no interior da cripta óssea que, por sua vez, se encontra em processo de remodelação. A fase seguinte, erupção intraóssea, consiste no deslocamento da coroa do germe dentário em direção oclusal através da via eruptiva, a qual consiste numa abertura criada na porção oclusal da cripta óssea pela reabsorção por osteoclastos. A fase de penetração na mucosa segue o deslocamento da coroa para o exterior da cripta, através da lâmina própria e do epitélio da mucosa oral, quando ocorre o primeiro contato com a cavidade oral. A partir deste momento, inicia-se a fase de erupção preoclusal, na qual a coroa erupciona até que atinja o contato oclusal com o dente antagonista. Mesmo após atingir o contato oclusal e serem finalmente estabelecidas todas as funções inerentes ao dente erupcionado, diversos fatores fisiológicos (como o desgaste oclusal do esmalte, por exemplo) ou patológicos (como a perda do elemento dental vizinho ou antagonista, por exemplo) desencadeiam o processo de erupção pós-oclusal, através do qual são buscados contatos oclusais e/ou laterais para que a função do dente se restabeleça (Marks e Schroeder, 2000).

Em todas as etapas da erupção dentária o tecido ósseo adjacente sofre intensa remodelação de modo a proporcionar o espaço ideal para o desenvolvimento do dente e durante a formação do periodonto de sustentação do mesmo. O processo de remodelação óssea ocorre através da atividade coordenada de osteoclastos e osteoblastos. Entretanto, como mencionado anteriormente, a região oclusal da cripta óssea requer a predominância do processo de reabsorção óssea por osteoclastos no momento da formação da via eruptiva. 
Os osteoclastos são células derivadas de células tronco hematopoiéticas que, ao serem recrutados para o tecido ósseo em resposta às moléculas M-CSF (Macrophage-Colony Stimulating Factor) e RANKL (Receptor Activator of NFKB Ligand), se fundem a outros precursores resultando em uma célula multinucleada. Esta célula é então ativada e adere à superfície óssea mineralizada formando uma zona de selamento. À porção da membrana plasmática cercada pela zona de selamento são direcionados canais iônicos, bombas iônicas e vesículas contendo enzimas que acidificam o compartimento e dissolvem o mineral e digerem a matriz orgânica da matriz óssea. Durante a ativação dos osteoclastos, o RANKL se liga a seu receptor na membrana destas células, o RANK (Receptor Activator of $N F K B$ ); para o cessamento ou inibição da ativação dos osteoclastos, a proteína osteoprotegerina (OPG) se liga ao RANKL, impedindo-o de se ligar ao RANK (Arana-Chavez e Bradaschia-Correa, 2009).

$\mathrm{Na}$ erupção dentária, o recrutamento de osteoclastos para a reabsorção óssea da porção oclusal da cripta é orquestrado pelo folículo dentário, um órgão constituído de tecido conjuntivo frouxo que envolve o germe dentário e cujas células secretam os fatores que promovem o recrutamento e ativação dos osteoclastos $\mathrm{M}$ CSF e RANKL, especialmente na região oclusal (Yao et al, 2004, Wise et al, 2005; Wise e Yao, 2006).

Uma vez que a função reabsortiva exercida por osteoclastos é fundamental durante o processo eruptivo, o uso de fármacos que interfiram nessa função em um modelo de experimentação animal pode ser considerado um interessante recurso para a compreensão da erupção dentária. Os bisfosfonatos são fármacos reconhecidamente capazes de interferir no metabolismo de osteoclastos, inibindo a reabsorção óssea. Tal efeito é explorado terapeuticamente em diversas patologias como a osteoporose, a Doença de Paget e metástases ósseas de tumores. Os bisfosfonatos são análogos ao pirofosfato inorgânico, um inibidor endógeno de processos de mineralização, em cuja molécula um átomo de oxigênio é substituído por um átomo de carbono, o qual é ligado a dois átomos de fósforo (P-C-P). Ao átomo de carbono também se ligam duas outras cadeias laterais, cuja composição determina as propriedades de cada bisfosfonato. 
Os bisfosfonatos podem ser classificados de acordo com a presença ou ausência de uma cadeia lateral nitrogenada. Os bisfosfonatos de primeira geração não possuem nitrogênio em sua molécula, e apresentam baixa potência antireabsortiva. As moléculas que possuem cadeia lateral nitrogenada são denominadas aminobisfosfonatos, e apresentam potência antireabsortiva maior. A composição molecular diferente implica em diferentes efeitos celulares de cada tipo de bisfosfonato sobre os osteoclastos e, no presente estudo, foram empregados dois bisfosfonatos, o etidronato (não-nitrogenado) e o alendronato (nitrogenado). Dessa forma, esperamos induzir a inibição da reabsorção óssea através de diferentes mecanismos, visando obter diferentes perspectivas de seu efeito sobre o processo eruptivo.

No presente estudo, o processo eruptivo do primeiro molar superior de ratos Wistar tratados com etidronato e alendronato desde $\mathrm{o}$ nascimento até aproximadamente quatro semanas de idade foi abordado em estudo morfológico, imunocitoquímico e bioquímico. O efeito dos bisfosfonatos sobre o germe dentário e o tecido ósseo, em especial os osteoclastos, foi realizado através de microscopia de luz, histoquímica TRAP e microscopia eletrônica de transmissão e varredura. Para avaliarmos o grau de remodelação do tecido ósseo da cripta, foi realizado o método imunocitoquímico para a localização ultra-estrutural em microscopia eletrônica de transmissão das proteínas não colágenas da matriz óssea osteopontina e sialoproteína, nos animais tratados com alendronato. $O$ efeito do alendronato sobre o sistema modulador da ativação dos osteoclastos RANK/RANKL/OPG foi estudado através do método imunocitoquímico e analisado em microscopia confocal de varredua a laser, além da análise da expressão destas proteínas na porção oclusal da cripta óssea pelo método Western Blotting. 
2 REVISÃO DE LITERATURA 
Antes de abordar a erupção dentária, será feita uma breve revisão sobre os tecidos e órgãos envolvidos neste processo, a saber, a odontogênese e o tecido ósseo.

\subsection{Odontogênese}

O processo de odontogênese consiste no desenvolvimento do dente. Inicia-se durante o período embrionário em humanos, por volta da quarta semana de vida a partir de interações epitélio-ectomesenquimais.

A odontogênese é precedida pela proliferação do epitélio oral primitivo, cujas células invadem o ectomesênquima subjacente em todo $\mathrm{o}$ arco dando origem à banda epitelial primária. A proliferação desta "muralha epitelial" se bifurca, dando origem à lâmina vestibular e à lâmina dentária, sendo esta última a que originará o arco dentário. A partir deste momento se dá o início de interações entre epitélio e ectomesênquima que persistem durante a formação da coroa e raiz de cada dente e respectivo periodonto de sustentação.

Em alguns pontos da lâmina dentária ocorrem alterações na atividade mitótica das células, as quais dão origem a pequenas esférulas epiteliais cercadas por evidente condensação de células mesenquimais ao redor. Estas estruturas são denominadas botões dentários e cada um deles origina um elemento dental. A proliferação epitelial persiste em cada um dos botões, porém de maneira desigual. As células da porção central da parte mais profunda do botão diminuem a velocidade de sua proliferação em relação às das regiões laterais, dando origem a uma concavidade. Além disso, há maior condensação do ectomesênquima nessa região, que acredita-se representar uma barreira física às células epiteliais em proliferação. Com isso, este tecido epitelial adquire formato característico de capuz dentário.

Uma vez estabelecida a fase de capuz, podem ser distinguidas as regiões do germe dentário. A porção epitelial passa a ser denominada órgão do esmalte, e apresenta uma morfologia peculiar em relação aos demais tecidos epiteliais. A partir 
da lâmina dentária, observam-se os epitélios interno e externo do órgão do esmalte e, entre eles, células epiteliais na região central distribuem-se de maneira esparsa com grande quantidade de substância fundamental, constituindo o retículo estrelado. O conjunto de células condensadas subjacente ao órgão do esmalte e a respectiva matriz extracelular é denominado papila dentária. $\mathrm{O}$ ectomesênquima que rodeia $\mathrm{o}$ germe dentário se denomina folículo dentário.

As células do órgão do esmalte continuam a se proliferar até certo ponto em que esta estrutura apresenta formato de sino. As células epiteliais da porção cervical do órgão do esmalte formam a alça cervical, onde se encontram os epitélios interno e externo. Nesta fase da odontogênese, denominada fase de campânula, a proliferação celular tanto das células epiteliais quanto das ectomesenquimais diminui e iniciam-se processos de diferenciação celular. Neste momento, a expressão do gene Runx2 parece ser essencial para que as diferenciações celulares ocorram e o germe dentário prossiga seu desenvolvimento (Chen et al, 2009), bem como para a adequada remodelação alveolar durante os movimentos eruptivos (Camilleri et al., 2006). O germe dentário envolto pelo folículo dentário passa a ser rodeado pelo osso alveolar que se forma ao redor, constituindo a cripta óssea, e perde a comunicação com o epitélio oral, restando apenas algumas células epiteliais na região que formam o gubernáculo ou canal gubernacular.

Durante o desenvolvimento dentário, fatores de crescimento como o TGF- $\beta$, BMPs, IGF e FGF promovem interações entre epitélio e ectomesênquima (Thesleff, 2003). As células do epitélio interno do órgão do esmalte iniciam um processo de diferenciação e, de cilíndricas baixas, tornam-se cilíndricas altas com núcleo localizado na região basal da célula, agora próxima ao estrato intermediário, invertendo sua polaridade, denominando-se pré ameloblastos. Previamente à fase secretora da amelogênese, a proteína amelogenina é sintetizada e secretada pelos pré-ameloblastos, e acredita-se que isso exerça alguma influência sobre a diferenciação das células da papila dentária em odontoblastos (Massa et al., 2006). As células ectomesenquimais da papila dentária, sob efeito das moléculas liberadas pelos pré ameloblastos, cessam sua proliferação e iniciam o processo de diferenciação em odontoblastos, momento em que secretam a dentina do manto, rica em colágeno do tipo I. Contatos entre odontoblastos e pré ameloblastos e a presença da matriz extracelular dentinária induzem a diferenciação final dos 
ameloblastos, que sintetizam a matriz orgânica do esmalte, constituída por proteínas não colágenas (Slavkin et al., 1976; Ruch et al., 1995;)

Durante a fase de coroa ou fase de campânula tardia da odontogênese, ocorre a deposição de esmalte e dentina que constituem a coroa do dente. A formação da dentina é centrípeta, enquanto a do esmalte é centrífuga.

Uma vez formada a coroa dental, inicia-se a fase de raiz, quando ocorre a formação da dentina radicular. As células da alça cervical do órgão do esmalte se proliferam apicalmente, sendo que a porção mais apical permanece e se dobra em direção à papila dentária, denominando-se diafragma epitelial. O início da proliferação desta bainha epitelial, também denominada bainha epitelial de Hertwig, coincide com o início da erupção dentária intra-óssea, que será abordado adiante. As células da camada interna da bainha epitelial de Hertwig induzem as células ectomesenquimais da papila dentária a se diferenciarem em odontoblastos, havendo nesse momento a secreção de uma pequena quantidade da proteína amelogenina que se acredita exercer papel sinalizador na diferenciação dos odontoblastos radiculares (Janones et al., 2005). Os odontoblastos diferenciados iniciam a secreção da dentina radicular, aumentando o comprimento da raiz. A bainha epitelial, por não acompanhar o crescimento radicular, se fragmenta, de modo que apenas a porção mais apical da bainha estabelece contato com a raiz em formação.

Ainda durante a fase de raiz é formado o periodonto de inserção. O cemento radicular, o ligamento periodontal e o osso alveolar são formados simultaneamente. As células ectomesenquimais do folículo dentário, sinalizadas por proteínas morfogenéticas ósseas (BMPs), deslocam-se para os espaços entre os fragmentos da bainha epitelial de Hertwig e se diferenciam em cementoblastos, que secretam a matriz orgânica do cemento sobre a dentina radicular. Nesse mesmo momento, células da região do folículo dentário próximas ao osso da cripta se diferenciam em osteoblastos e formam o osso alveolar (Zeichner-David, 2006). As células da região central do folículo dentário se diferenciam em fibroblastos, os quais secretam abundantes feixes de colágeno do ligamento periodontal cujas extremidades ficam inseridas na matriz de cemento e osso alveolar, sendo denominadas fibras de Sharpey, além de outras fibras como as oxitalânicas. 
Morfologicamente, a bainha epitelial de Hertwig é um limite estrutural entre dois tecidos dentais mesenquimais, a papila dentária e o folículo dentário. Esta posição estratégica sugere um papel importante para a bainha durante as interações entre o epitélio dental e o ectomesênquima, bem como para a formação da camada hialina, importante para a adesão entre cemento e dentina radicular (TomazelaHerndl e Arana-Chavez, 2001, 2004).

Estudos anteriores demonstraram que genes como as proteínas morfogenéticas ósseas (BMPs), fatores de crescimento de fibroblastos (FGF), sonic hedgehog (Shh), Notch, Gli, MSX2 e Nfic (fator nuclear Ic), estão envolvidos no desenvolvimento da raiz do dente. $O$ fator de crescimento transformador $\beta$ (TGF- $\beta$ ) da superfamília das citocinas é composto de TGF- $\beta$ s, BMPs, ativinas e proteínas relacionadas. A sinalização pelo TGF- $\beta$ desempenha papel importante na regulação de um amplo espectro de processos biológicos tais como a proliferação celular, diferenciação, apoptose e remodelação da matriz extracelular (Huang et al., 2010).

$O$ desenvolvimento radicular envolve a sinalização da TGF- $\beta / B M P$ na bainha radicular de Hertwig. Um dos elementos-chave nesta via é a Smad4, uma proteína que regula a expressão de uma variedade de genes-alvo. A inativação da Smad4 dental em células epiteliais ocasiona a interrupção do desenvolvimento radicular de molares e afeta severamente a amelogênese e dentinogênese; dessa forma, acredita-se qua a sinalização TGF- $\beta$ /BMP, incluindo a Smad4, controla uma hierarquia genética envolvendo os fatores Shh e Nfic, que por sua vez desempenham um papel crucial na regulação da interação epitélio-ectomesênquima durante o desenvolvimento da raiz (Huang e Xu, 2010).

Enquanto ocorre a rizogênese e o processo de erupção dentária avança, o órgão do esmalte ainda reveste a coroa, cujo esmalte encontra-se em processo de maturação. Este epitélio, após o término da amelogênese, involui, denominado-se epitélio reduzido do órgão do esmalte. Após a erupção do dente, este epitélio contribui para a formação do epitélio juncional da gengiva.

\subsection{Tecido Ósseo}

O tecido ósseo é um tecido conjuntivo cuja matriz extracelular é mineralizada, característica esta que the confere rigidez e resistência. Os ossos, estruturas 
compostas de tecido ósseo, compõem o esqueleto do organismo, o que inclui os ossos maxilares abordados no presente estudo.

\subsubsection{Células}

Existem no tecido ósseo células formadoras e degradadoras de matriz. As células formadoras de matriz óssea têm origem ectomesenquimal na região craniofacial, que se diferenciam em osteoblastos. Durante a formação da matriz, alguns osteoblastos são aprisionados nesta, de onde emitem prolongamentos, sendo denominados osteócitos. As células que revestem o tecido ósseo e não apresentam atividade secretora são denominadas células de revestimento ósseo, as quais possuem potencial osteogênico. A matriz formada pelos osteoblastos é degradada por osteoclastos, células originadas de precursores hematopoiéticos que são recrutados para regiões em que a reabsorção óssea é necessária, os quais se fundem, dando origem a células multinucleadas que se aderem à matriz mineralizada e a degradam.

\subsubsection{Osteoblastos}

Osteoblastos são células polarizadas sintetizadoras e secretoras de matriz extracelular de formato cubóide, cujo citoplasma possui estrutura característica dessa condição. Apresentam núcleo arredondado com cromatina frouxa e nucléolo evidente, abundantes cisternas de retículo endoplasmático rugoso, aparelho de Golgi proeminente e desenvolvido, numerosas vesículas de secreção e lisossomos.

Quando em estado quiescente, os osteoblastos têm o conteúdo de seu citoplasma reduzido, seu formato torna-se mais achatado, assim como o formato de seu núcleo, e seu arranjo lado a lado assemelha-se a um epitélio simples, sendo denominados células de revestimento ósseo (Hirashita, 1996).

Os osteoblastos e células de revestimento ósseo podem apresentar moléculas em sua membrana plasmática, o RANKL e a OPG, que atuam como ativadores e inibidores, respectivamente, da atividade de osteoclastos (Arana-Chavez e Bradaschia-Correa, 2009). 


\subsubsection{Osteócitos}

Os osteócitos são células alojadas em lacunas no interior da matriz óssea que possuem numerosos prolongamentos com aspecto dendrítico que ocupam os canalículos que partem das lacunas. São originados de osteoblastos que, durante a secreção da matriz, foram envolvidos por ela por todos os lados. Os prolongamentos de cada osteócito se encontram com prolongamentos de osteócitos vizinhos e estabelecem junções comunicantes entre si. $O$ fluido canalicular preenche o espaço entre osteócitos e suas lacunas, e sua difusão pelo sistema lacuno-canalicular garante a difusão de nutrientes para o interior da matriz óssea. Estas características outorgam a função mecanosensora que, em conjunto com outros fatores, influencia o metabolismo ósseo.

No momento que estão sendo envolvidos pela matriz óssea, o citoplasma dos osteócitos apresenta conteúdo semelhante ao de osteoblastos em atividade de síntese e secreção, sendo denominados, dessa forma, osteócitos osteoides. Os osteócitos osteoides regulam a biomineralização da matriz osteoide a seu redor, expressando neste momento genes como o da proteína da matriz dentinária 1 (DMP-1) (Bonewald, 2011). Entretanto, dentre os osteoblastos destinados ao aprisionamento na matriz, tal processo pode ser ativo, em células que continuam a secretar matriz enquanto são aprisionadas, ou passivo, em células que cessam completamente a atividade secretora durante este processo (Franz-Odendaal et al., 2006). Os osteócitos maduros apresentam menor volume do citoplasma, típico de células em estado quiescente. Também espressam a proteína esclerostina, um marcador específico de células do tecido ósseo em ausência de atividade osteogênica (Bonewald, 2011).

\subsubsection{Osteoclastos}

Os osteoclastos são derivados de células tronco-hematopoiéticas especializadas em degradar a matriz óssea mineralizada. Os osteoclastos são geralmente gigantes e multinucleados e, quando em atividade, são polarizados. $\mathrm{O}$ osteoclasto em atividade reabsortiva adere-se à matriz óssea através de estruturas 
características denominadas podossomos. $\mathrm{Na}$ membrana plasmática dos podossomos há presença de integrinas do tipo av $\beta 3$, que interagem com a sequência RGD de proteínas não colágenas do substrato ao qual está aderido, como a osteopontina e sialoproteína óssea. Entretanto, estudos demonstram a capacidade de células clásticas de se aderirem ao esmalte, um tecido desprovido de proteínas que contenham sequência RGD (Arana-Chavez e Andia-Merlin, 1998). O córtex celular correspondente aos podossomos apresenta uma zona de selamento caracterizada pela formação de um anel composto por filamentos de actina arranjados paralelamente, de modo a formar um cinturão (McMichaeL et al., 2006). Quando examinada em MET, esta região do citoplasma dos osteoclastos apresentase livre de organelas e, devido a este aspecto, é normalmente denominada zona clara. O podossomo delimita os domínios celulares da membrana dos osteoclastos; a porção da membrana contida no interior da zona de selamento é denominada borda em escova e externamente à zona de selamento está o domínio basolateral (Arana-Chavez e Bradaschia-Correa, 2009).

No citoplasma dos osteoclastos são encontradas as típicas organelas relacionadas à função sintetizadora de proteínas, como cisternas do retículo endoplasmático rugoso, aparelho de Golgi. Os núcleos geralmente apresentam a cromatina frouxa. São observadas também muitas mitocôndrias, indicando o alto consumo de energia durante a atividade reabsortiva. Na região do citoplasma que se estende da borda em escova ao domínio secretor funcional observam-se numerosos vacúolos, vesículas, endossomos e lisossomos (Arana-Chavez e Bradaschia-Correa, 2009).

A membrana plasmática na região da borda em escova apresenta numerosas invaginações que outorgam aspecto pregueado, além dos numerosos vacúolos no citoplasma contribuirem com este aspecto. Na membrana dos vacúolos e lisossomos no citoplasma dos osteoclastos, assim como em outras células do organismo, existe uma bomba de prótons denominada ATPase vaculoar (V-ATPase) que promove a acidificação do compartimento onde substâncias são degradadas. Nos osteoclastos, a V-ATPase apresenta a subunidade B2 específica que permite a ligação desta bomba a microfilamentos do citoesqueleto, condição sine qua non para que seja direcionada à membrana da borda em escova (Lee et al, 1999, Zuo et al., 2006) 
Estas células são originadas em resposta ao recrutamento às superfícies mineralizadas em situações fisiológicas ou patológicas quando há estímulo para a reabsorção óssea. Além da matriz óssea, outros tecidos mineralizados do organismo como a dentina, cemento e esmalte podem ser reabsorvidos por odontoclastos e cementoclastos (Arana-Chavez e Bradaschia-Correa, 2009).

O processo de osteoclastogênese, pelo qual os osteoclastos se formam, envolve o recrutamento de seus precursores hematopoiéticos. O fator estimulante de colônia de macrófagos (M-CSF) se liga ao receptor c-FMS, presente na membrana das células precursoras, estimulando a proliferação e fusão entre estas células. Outro sistema regulador da osteoclastogênese é o RANK/RANKL/OPG. O RANK (receptor activator of $N F K B$ ) é um receptor da superfamília de receptores TNF (tumour necrosis factor) presente na membrana plasmática de células precursoras e também de osteoclastos diferenciados. Este receptor sinaliza a proliferação e fusão de precursores e também ativa a função reabsortiva dos osteoclastos, sendo este fenômeno dependente do acoplamento de seu ligante, o RANKL (receptot activator of $N F K B$ ligand). O RANKL é expresso na membrana ou secretado por células mesenquimais osteoprogenitoras, células de revestimento ósseo e osteoblastos. A OPG (osteoprotegerina) é também produzida por células mesenquimais osteoprogenitoras e osteoblastos. É considerada outro receptor do RANKL e, quando se liga ao RANKL, impede a fusão e ativação dos osteoclastos.

\subsubsection{Matriz Extracelular}

A matriz extracelular do tecido ósseo é composta por uma fase orgânica e uma fase mineral. A matriz orgânica é composta por $85 \%$ de colágeno do tipo I, $5 \%$ de colágeno do tipo III e V. Os 10\% restantes são proteínas não colágenas como a osteocalcina, osteonectina, sialoproteína óssea (BSP), osteopontina (OPN), SPARC (secreted protein, acidic, cysteine-rich"), os proteoglicanos/glicosaminoglicanos decorin, biglican, lumican e osteoaderina, além de proteínas morfogenéticas ósseas (BMPs) e proteínas séricas. A fase mineral da matriz óssea é composta por fosfato de cálcio na forma de cristais de hidroxiapatita. A proporção entre as fases orgânica e mineral na matriz é de $20 \%$ orgânica, $65 \%$ mineral e os $15 \%$ restantes são água (Katchburian e Arana-Chavez, 2004). 
Durante o início da formação óssea, os osteoblastos depositam uma matriz constituída por fibrilas de colágeno do tipo I e proteoglicanos sulfatados de cadeias longas, do tipo condroitin, heparan e dermatan sulfato. Esta matriz então se mineraliza, e os osteoblastos passam a secretar uma matriz constituída por $90 \%$ de colágeno (sendo a maior parte colágeno tipo I, contendo também colágeno tipo III e V) e o restante por componentes não colágenos que se associam às fibrilas colágenas, que medeiam o processo de mineralização. A OPN e a BSP são proteínas não colágenas de grande importância neste fenômeno. São proteínas altamente fosforiladas, o que as outorga com grande afinidade pela hidroxiapatita, além de possuir a sequência RGD que permite a ligação a integrinas da membrana plasmática das células. Além das células e da hidroxiapatita, a osteopontina e a sialoproteína óssea se ligam ao colágeno e às outras proteínas da matriz, resultando na propriedade de adesão, razão pela qual sua presença é importante nas linhas cimentantes.

A matriz óssea é passível de remodelação, processo realizado pelo acoplamento das funções reabsortivas de osteoclastos $e$ formadoras de osteoblastos (Arana-Chavez e Bradaschia-Correa, 2009). Durante o crescimento e desenvolvimento do esqueleto ósseo ocorre intenso processo de remodelação óssea.

Durante a remodelação óssea, os osteoblastos ou células de revestimento ósseo de uma determinada área cessam a deposição da matriz, degradam o osteóide e se afastam da superfície óssea, sofrendo apoptose. Os osteoclastos se aderem à matriz mineralizada e iniciam o processo de reabsorção. Após a fase de reabsorção, os osteoclastos se afastam da matriz, sofrendo também apoptose. Células indiferenciadas são atraídas para a região, diferenciando-se em novos osteoblastos, os quais depositam OPN e BSP que desempenham importante papel na adesão entre a superfície mineralizada reabsorvida e a nova matriz secretada. As linhas cimentantes originadas entre uma superfície reabsorvida e uma nova matriz são denominadas linhas de reversão; as linhas formadas pela deposição óssea após períodos de repouso, quando os osteoblastos retomam a deposição de matriz, são denominadas linhas cimentantes aposicionais. Em geral as linhas aposicionais apresentam aspecto ultraestrutural liso e regular, enquanto as linhas de reversão são irregulares (Arana-Chavez e Nanci, 2001). 
O tecido ósseo cuja matriz extracelular recém formada geralmente apresenta numerosas linhas cimentantes aposicionais, além de osteócitos alojados em lacunas randomicamente localizadas pela matriz, é denominado osso primário. Com os sucessivos eventos de remodelação que ocorrem no osso durante a vida no organismo, o aspecto da matriz extracelular se modifica, havendo a presença de linhas de reversão e incrementos ósseos lamelares, havendo também o arranjo ordenado de lacunas de osteócitos entre as lamelas tanto no osso compacto quanto no osso esponjoso. Este tecido ósseo é classificado como osso maduro ou lamelar. A distribuição das proteínas OPN e BSP nas linhas cimentantes são indicativas do nível de remodelação do tecido ósseo (Arana-Chavez e Nanci, 2001).

\subsubsection{Osteopontina}

A osteopontina (OPN) é uma das proteínas não colágenas mais abundantes da matriz orgânica dos tecidos mineralizados, além de estar presente em todos os fluidos corporais. Possui peso molecular de aproximadamente $41,5 \mathrm{kDa}$, sendo primariamente isolada do osso de ratos, humanos e bovinos (Franzen e Heinegard, 1985; Prince et al., 1987). Como já mencionado, esta molécula participa dos processos de biomineralização da matriz por conter um domínio de ácido poliaspártico, o qual permite à molécula se ligar a íons cálcio e à hidroxiapatita. $\mathrm{A}$ molécula de osteopontina também apresenta a sequência RGD (arginina - glicina ácido aspártico), a qual permite sua ligação a células.

A osteopontina não apresenta um domínio de ligação da molécula ao colágeno. É sintetizada por pré-osteoblastos, osteoblastos e osteócitos e, após ser secretada para a matriz, incorporada ao osso. A osteopontina também apresenta capacidade de ligar células ósseas à hidroxiapatita, sendo um agente de união (Young et al., 1991). Também se localiza em superfície ósseas onde estão aderidos osteoclastos, sugerindo que a proteína ligue o osteoclasto à superfície óssea mineralizada através da interação com os receptores de vitronectina em sua membrana (Reinholt et al., 1990).

\subsubsection{Sialoproteína Óssea}

A sialoproteína óssea (BSP) foi inicialmente isolada como uma glicoproteína acídica de 23-kDa rica em ácido siálico, e representa de 8 a 12\% do volume de 
proteínas não colágenas do osso e cemento. É expressa de estritamente em tecidos mineralizados como osso, cartilagem calcificada, dentina e cemento (Fisher et al., 1990), sendo maior sua expressão no osso e cemento neoformados (Shen et al., 1995).

A sialoproteína óssea compartilha algumas características com a osteopontina. Assim como a OPN, apresenta a seqüência RGD relacionada à capacidade de adesão celular, porém localizada em outro sítio da molécula, mais próxima ao terminal carboxila. Estudos mostram que a sialoproteína óssea é encontrada em células formadoras de osso maduro e não em seus precursores imaturos, indicando que esta proteína seja um marcador de osteoblastos (Bianco et al., 1991) e osteócitos (Arai et al., 1995) diferenciados. Especula-se que também desempenhe algum papel na função reabsortiva de osteoclastos (Young et al., 1991).

Apesar dos estudos imunohistoquímicos, isto é, em microscopia de luz, mostrarem que tanto a BSP quanto a OPN não se distribuem em toda a matriz mineralizada; sua localização ultra-estrutural mostra que se acumulam nos espaços interfibrilares, linhas cimentantes e laminae limitans, sendo proposta a idéia de que serviriam como agentes de união entre tecidos mineralizados (McKee e Nanci, 1995; McKee e Nanci, 1996; Nanci, 1999; Arana-Chavez e Nanci, 2001).

\subsection{Erupção Dentária}

A erupção dentária é um processo pelo qual os dentes, que são inicialmente formados no interior de uma cripta óssea nos maxilares, se deslocam em direção à cavidade oral de modo que apenas sua coroa fique exposta à mesma. Para tal deslocamento é necessária a formação de um caminho através do tecido ósseo que recobre a coroa do dente, o que é permitido graças à reabsorção exercida pelos osteoclastos.

A reabsorção óssea é necessária para que ocorra a fase intra-óssea do processo eruptivo e também prover o espaço necessário para acomodar o germe dentário em desenvolvimento, os primeiros movimentos preeruptivos, bem como o aumento do rebordo ósseo como um todo. $\mathrm{Na}$ fase em que a erupção dentária ocorre, os maxilares e especialmente seus processos alveolares, estão se 
desenvolvendo através de um processo dinâmico que envolve a formação e reabsorção do tecido ósseo.

Por volta da fase de capuz da odontogênese dos molares do rato, nos últimos dias da gestação, o osso do processo alveolar da maxila e da mandíbula é constituído por trabéculas de osso imaturo que se desenvolvem oclusalmente, rodeando os germes dentários, formando a base e as paredes laterais da cripta óssea. A formação do osso basal ocorre a partir da fusão de trabéculas de osso primário que se anastomosam enquanto os processos maxilares e mandibulares crescem como um todo. O osso primário ou imaturo apresenta maior número de osteócitos que o osso secundário, dispostos irregularmente e alojados em lacunas arredondadas; sua matriz apresenta fibras colágenas sem organização definida e deixando amplos espaços nos quais se alojam proteínas não colágenas. Quando é atingida a fase de campânula, por volta do nascimento, o processo alveolar acaba por rodear completamente o germe, restando apenas o canal gubernacular como uma estreita comunicação com o epitélio oral. Forma-se, assim, o teto da cripta óssea. Entretanto, a permanência das delgadas trabéculas do teto da cripta é muito curta e logo aparecem osteoclastos para reabsorvê-las. Primeiramente, para permitir o crescimento da coroa do dente pela aposição de dentina e esmalte durante a fase de coroa, e depois, para permitir a erupção do dente, coincidindo com a fase de raiz (Katchburian e Arana-Chavez, 2004).

Frente à necessidade de crescimento do osso, ocorrem os eventos de remodelação. O osso primário é gradualmente substituído por osso secundário ou maduro, caracterizado por possuir menos osteócitos que o primário. Estes se apresentam regularmente dispostos e alojados em lacunas achatadas. Sua matriz orgânica apresenta fibrilas colágenas organizadas mais densamente e em lamelas, as quais podem ser concêntricas ou paralelas.

Diversas teorias foram propostas no passado para explicar o mecanismo da erupção dentária. Já foram considerados: a pressão pulpar, o crescimento pulpar, a tração por fibroblastos periodontais e a pressão vascular. Porém, o crescimento radicular, a remodelação óssea do alvéolo e, talvez, a formação do ligamento periodontal, são possivelmente os eventos mais relacionados com a erupção dentária. A remodelação do osso da cripta seria conseqüência das pressões 
geradas pelo movimento eruptivo do dente. Assim sendo, a formação do osso alveolar, a formação do dente e a erupção dentária são eventos interdependentes. (Marks e Schroeder, 1996).

Em relação ao primeiro molar superior do rato, o primeiro pico de osteoclastogênese ocorre aos 4 dias de vida (Wise et al., 1995), época em que está ocorrendo a fase de coroa da odontogênese e se iniciando a fase de erupção intraóssea. Durante os próximos dias, numerosos osteoclastos mono e multnucleados estão presentes entre o órgão do esmalte do germe dentário e o osso alveolar (Wise e Fan, 1988). Um segundo pico de aumento no número de osteoclastos na porção oclusal da cripta óssea ocorre aos 10 dias (Cielinski et al., 1994), sendo que a formação radicular no primeiro molar superior inicia-se aos 12-13 dias. A quantidade destas células diminui por volta do décimo sexto dia, quando o primeiro molar se encontra em processo de erupção preoclusal (Wise e Fan, 1988). O aparecimento deste dente na cavidade oral ocorre aos 19-20 dias, alcançando o plano oclusal funcional aos 25-26 dias (Schour e Massler, 1949).

A presença e a atividade dos osteoclastos durante os diferentes momentos do processo eruptivo depende de complexos mecanismos de sinalização que vêm sendo elucidados ao longo das últimas décadas. Antes de abordar a literatura a respeito do mecanismo de recrutamento, ativação e a atividade reabsortiva propriamente ditos de osteoclastos, deve ser lembrado que, no contexto da erupção dentária, as células envolvidas não se restringem ao tecido ósseo, sendo desempenhado importante papel pelo folículo dentário que circunda o germe dentário e o órgão do esmalte.

O folículo dentário é um tecido conjuntivo frouxo que envolve os germes dentários como uma cápsula. Estudos realizados na década de 1980 abordaram a importância deste órgão de diversas formas. A remoção do folículo dentário de germes de premolares de cães impede que a erupção dentária ocorra (Cahill e Marks, 1980). Contrariamente, removendo-se o germe dentário e inserindo-se uma réplica artificial, foi possível observar a erupção da réplica (Marks e Cahill, 1984). A partir destes achados, importante atenção foi dada ao folículo dentário como regulador do processo eruptivo em estudos subsequentes. 
O folículo dentário apresenta alta expressão do CSF-1 no terceiro até o décimo segundo dia após o nascimento de ratos, coincidindo com o período em que há maior osteoclastogênese (Wise e Lin, 1995). Neste período, os osteoclastos multinucleados expressam o receptor para o fator CSF-1, c-Fms, em sua membrana (Kawakami et al., 1999). A expressão de CSF-1 pelas células do folículo dentário é associada ao aumento do fator de transcrição c-fos pelos precursores de osteoclastos (Wise et al, 2002), e também à redução da expressão de OPG durante o pico de osteoclastogênese observado no terceiro dia (Wise et al., 2005).

A expressão da proteína RANKL, outra molécula reguladora da osteoclastogênese, também ocorre no folículo dentário (Yao et al., 2004), sendo mais elevada nos períodos de 9 a 11 dias de idade em ratos (Liu et al., 2005).

A proteína relacionada ao paratormônio (PTHrP) e a interleucina-1a (IL-1a) são produzidas por células do retículo estrelado do órgão do esmalte e seus respectivos receptores, o PTHrP-R e o IL-1R, são encontrado tanto em células do tecído ósseo alveolar da cripta como em células do folículo dentário. Estas moléculas se difundem e agem paracrinamente sobre as células do folículo dentário, onde estimulam a expressão de CSF-1 e da proteína quimiotática de monócitos 1 (MCP-1) e, consequentemente, a reabsorção óssea por osteoclastos (Wise et al., 1995; Wise, et al., 2003).

Uma vez recrutados para o osso alveolar da cripta, sinalizações persistem com o intuito de modular a atividade dos osteoclastos. Além disso, as diferentes regiões da cripta óssea devem apresentar diferentes níveis de reabsorção e formação óssea. Experimentos em que as regiões oclusal e basal da cripta óssea foram isoladas pela técnica de microdissecção a laser para análise da expressão dos genes associados à reabsorção e formação óssea RANKL e BMP-2, respectivamente, demonstraram que na região basal houve maior expressão de BMP-2, enquanto a região oclusal apresentou maior expressão de RANKL. Tais resultados foram observados do primeiro ao décimo primeiro dia pós-natal de ratos, indicando que há diferença na expressão de diferentes mediadores do metabolismo ósseo em cada região do folículo dentário (Wise e Yao, 2006). 


\subsection{Bisfosfonatos}

Os bisfosfonatos constituem um grupo fármacos com propriedade antireabsortiva amplamente utilizados no tratamento de patologias ósseas como osteoporose, doença de Paget e também metástases ósseas de carcinomas (Coxon et al., 2006; Russell et al., 2008). Sua estrutura química é semelhante ao do pirofosfato inorgânico, uma molécula endógena que regula a biomineralização óssea. Nos bisfosfonatos, o átomo central de oxigênio do pirofosfato é substituído por um átomo de carbono, ao qual dois radicais fosfato são ligados (Rogers et al., 2000). Essa estrutura confere aos bisfosfonatos, afinidade por hidroxiapatita e, conseqüentemente, à superfície mineral óssea (Vasikaran, 2001). Com a descoberta de que os bisfosfonatos, além de inibirem a dissolução e crescimento de cristais de mineral, apresentam efeitos celulares sobre osteoclastos, seu uso em patologias caracterizadas por perda de densidade óssea se tornou amplamente difundido (Russell et al., 1999). O mecanismo de ação dos diferentes tipos de bisfosfonato, bem como a potência antireabsortiva dos mesmos, estão vinculados à composição de suas cadeias laterais.

Os bisfosfonatos que apresentam o radical hidroxila $(\mathrm{OH})$ ou um átomo de cloro (Cl) em uma das cadeias laterais são os de menor potência. Estes bisfosfonatos de primeira geração atuam no metabolismo do ATP de osteoclastos, a partir do qual resultam produtos não hidrolisáveis que se acumulam em seu citoplasma e inibem diversas enzimas, comprometendo o metabolismo, função e a sobrevivência destas células (Russell, 2006). São representantes desta classe de bisfosfonatos o clodronato e o etidronato, sendo este último analisado no presente estudo. $O$ efeito do etidronato sobre a dentinogênese e amelogênese em incisivos de ratos é bem descrito na literatura, sabe-se que é capaz de ocasionar hipomineralização destes tecidos por atuarem sobre a mineralização da matriz de dentina e esmalte (Beertsen et al., 1985; Weile et al., 1990; Josephsen et al., 1990; Fejerskov et al., 1990; Weile et al., 1993; Brandsten et al., 1995; Sakai et al., 1999; Fuangtharnthip et al., 2000). O etidronato é capaz de inibir a mineralização do osteóide, impedindo a maturação de osteócitos (Irie et al., 2008).

Os bisfosfonatos que possuem um radical $-\mathrm{NH}_{2}$ apresentam aumento significativo de sua potência reabsortiva e são denominados bisfosfonatos nitrogenados, os bisfosfonatos de segunda geração (Rogers et al., 2000). Os bisfosfonatos nitrogenados apresentam maior afinidade por cristais de hidroxiapatita 
e fosfato octacálcico. Seu efeito celular sobre osteoclastos é diferente do das drogas não nitrogenadas, sendo demonstrado que ocasionam a inibição da via do mevalonato. Uma vez inibida esta via, são inibidas as sínteses do colesterol e lipídios isoprenóides como 0 isopentenildifosfato, 0 farnesildifosfato e o geranilgeranildifosfato, moléculas essenciais às modificações pós-traducionais de GTPases Ras, Rho, Rab e Rac, essenciais a diversas funções celulares (Van Beek et al., 2002; Russell, 2006). As GTPases Rho orientam a formação de podosomos (Jurdic et al., 2006; Ory et al., 2008), e as GTPases Rab, o tráfego de vesículas pelo citoplasma e a formação da borda em escova dos osteoclastos (Taylor et al., 2011). Além disso, alguns estudos apontam evidências de que a inibição da atividade de osteoclastos por bisfosfonatos seja mediada por osteoblastos (Vitté et al., 1996). São exemplos de bisfosfonatos nitrogenados o risedronato, ibandronato, alendronato e ácido zoledrônico.

O alendronato sódico é o bisfosfonato mais prescrito atualmente (Ruggiero et al., 2009). Após infusão endovenosa, é rapidamente eliminado do plasma e $40 \%$ são excretados pela urina, não sendo metabolizado no organismo. Como os demais bisfosfonatos, liga-se rapidamente à hidroxiapatita do osso, e sua meia-vida de eliminação estimada é de 12 anos (Vasikaran, 2001). O alendronato liga-se a superfícies ósseas durante o processo de reabsorção. A liberação da droga adsorvida à matriz mineralizada também ocorre na reabsorção, quando ocorre a acidificação da matriz, e é então internalizada pelos osteoclastos (Sato et al, 1991). Experimentos in vitro demonstraram que o alendronato impede a reabsorção óssea sem que ocorra apoptose (Halasy-Nagy et al., 2001).

Além dos efeitos sobre o tecido ósseo, foi demonstrado que o alendronato sódico é capaz de alterar a secreção da matriz orgânica do esmalte durante a amelogênese de molares de ratos, sem prejudicar, no entanto, a maturação final do esmalte (Massa et al., 2006). Além disso, foi demonstrado que o bisfosfonato pamidronato é capaz de atrasar a erupção de incisivos e molares de ratos (Grier e Wise, 1998). Estudos recentes utilizando o bisfosfonato de terceira geração ácido zoledrônico mostrou que este é capaz de induzir anomalias dentárias e a formação de odontomas, além de impedirem a erupção dentária (Hiraga et al., 2010).

No presente estudo, buscamos induzir alterações no processo de reabsorção óssea por osteoclastos através da administração dos bisfosfonatos etidronato e alendronato de sódio, durante as quatro primeiras semanas de vida de ratos e, com 
isso, interferir no processo de erupção dentária. Foram analisados os primeiros molares superiores utilizando-se diferentes abordagens, compreendendo aspectos morfológicos e imunocitoquímicos do tecido ósseo e do germe dentário em desenvolvimento, e bioquímicos, pela análise das moléculas reguladoras da osteoclastogênese RANK, RANKL e OPG. 
3 PROPOSIÇÃO 
O presente trabalho teve como objetivo estudar o efeito dos fisfosfonatos no mecanismo de reabsorção óssea por osteoclastos através da administração dos bisfosfonatos alendronato sódico e etidronato a ratos recém-nascidos durante o desenvolvimento e erupcão dentária destes animais. Dessa forma, pretendemos analisar os seguintes aspectos ocorridos no processo alveolar:

- Avaliação morfológica do tecido ósseo da cripta ao redor do germe dentário, bem como evidenciação das células clásticas;

- Análise ultra-estrutural do tecido ósseo alveolar;

- Imunolocalização ultra-estrutural das proteínas OPN e BSP no osso alveolar;

- Imunolocalização das proteínas RANK, RANKL e OPG no osso alveolar através de microscopia confocal;

- Semi-quantificação das proteínas reguladoras da atividade de osteoclastos, RANK, RANKL e OPG na porção oclusal da cripta óssea por Western Blotting.

- Análise do efeito do alendronato sobre células osteoclasto-like in vitro.

Através do estudo proposto, esperamos elucidar detalhes sobre a osteoclastogênese e a remodelação óssea, e a sua importância durante o desenvolvimento radicular e erupção de molares de ratos. 
4 MATERIAIS E MÉTODOS 


\subsection{Tratamento dos animais com bisfosfonatos}

No presente estudo foram utilizados 212 ratos Wistar (Rattus norvegicus) albinos, de ambos os sexos, os quais foram tratados diariamente com bisfosfonatos ou apenas veículo a partir do primeiro dia após o nascimento, até $4,8,14,21$ e 28 dias de idade. Os tratamentos realizados foram aprovados pelo Comitê de Ética em Experimentação Animal (CEEA) do Instituto de Ciências Biomédicas da Universidade de São Paulo.

As doses utilizadas nos tratamentos foram $2,5 \mathrm{mg} / \mathrm{kg}$ (Massa et al., 2006) e 8 $\mathrm{mg} / \mathrm{kg}$ (Takano et al., 1998) de alendronato de sódio e etidronato, respectivamente. A massa corpórea dos animais foi aferida diariamente em balança digital e as soluções de alendronato ou etidronato foram preparadas utilizando tampão PBS como veículo. Foi injetado subcutaneamente no dorso dos animais um volume de 10 $\mu \mathrm{L}$ de solução, após antissepsia prévia com álcool $70 \%$. Nos animais controles, foi injetado o mesmo volume de PBS.

\subsection{Obtenção dos espécimes e fixação}

Nos dias anteriormente citados, quatro animais tratados com cada bisfosfonato e dois controles de cada idade foram anestesiados por via intramuscular com uma combinação de ketamina e xilazina, sendo a dose de 0,1 mL de cada solução para $100 \mathrm{~g}$ de massa corporal. Em seguida, foram eutanasiados por decapitação tiveram os processos alveolares da maxila removidos e prontamente imersos em solução fixadora de acordo com cada modalidade de análise morfológica. O béquer contendo os espécimes imersos na solução fixadora foi posicionado no centro de uma forma de vidro contendo gelo picado, e o conjunto foi posicionado no interior de um forno de microondas Pelco 3440 (Ted Pella, Redding, CA. USA). Um termômetro foi imerso na solução fixadora durante a operação do forno a fim de monitorar a temperatura da mesma, a qual não ultrapassou $37^{\circ} \mathrm{C}$. Os espécimes foram expostos a 3 ciclos de 5 minutos a 100\% de potência. Após a 
irradiação de microondas, foram imersos em nova solução fixadora overnight a $4^{\circ} \mathrm{C}$ (Massa e Arana-Chavez, 2000).

Em seguida, os espécimes analisados em microscopia de luz e microscopia eletrônica de transmissão foram lavados durante uma hora em solução tampão cacodilato de sódio a 0,1M, pH 7,2 e descalcificados em EDTA a 4,13\% (Warshawsky e Moore, 1967) durante aproximadamente quinze dias.

\subsection{Método histoquímico TRAP}

Foram analisados através do método histoquímico TRAP (Tartrate resistant acid phosphatase) espécimes controles e tratados com alendronato com 4, 8, 14, 21 e 28 dias de idade, e etidronato com 4, 8, 14 e 28 dias de idade. Os espécimes obtidos foram fixados em solução Karnowsky modificada, contendo $2 \%$ de glutaraldeído e 2,5\% de formaldeído (preparado a partir de paraformaldeído) em tampão cacodilato de sódio a 0,1M, pH 7,2 e descalcificados como descrito no item anterior. Posteriormente, foram lavados em tampão cacodilato de sódio a $0,1 \mathrm{M}, \mathrm{pH}$ 7,2 durante uma hora, desidratados em concentrações crescentes de etanol, banhados em acetona, infiltrados e incluídos em historesina JB-4 (Polysciences, Philadelphia, PA, USA) em cápsulas Beem. Cortes de aproximadamente $3 \mu \mathrm{m}$ foram obtidos em um micrótomo Microm HM360 (Microm, Waldorf, Germany) com a utilização de facas de vidro preparadas no knife-maker Leica EM KMR3 (Leica, Wetzlar, Germany). As lâminas onde foram coletados os cortes permaneceram em estufa a $40^{\circ} \mathrm{C}$ durante pelo menos 24 horas. Para a incubação, foi preparada a solução completa de Burstone, dissolvendo-se $4 \mathrm{mg}$ de "naphotol AS-BI phosphate substrate" em 0,25 ml de N,N-dimetil-formamida, seguido da adição de $25 \mathrm{~mL}$ de tampão acetato 0,2M pH5,0, $35 \mathrm{mg}$ de Fast Red Violet LB e $60 \mu \mathrm{L}$ de $\mathrm{MgCl}$ a 10\%. A solução foi filtrada e aquecida a $37^{\circ} \mathrm{C}$ durante 5 minutos e, em seguida, adicionouse ácido tartárico $\mathrm{D}(-)$ a uma concentração final de $50 \mathrm{mM}$. Os cortes semi-seriados foram incubados a $37^{\circ} \mathrm{C}$ durante 3 horas, lavados durante 10 minutos em água corrente e contracorados com Hematoxilina de Harris. As lâminas foram montadas utilizando-se como meio o Entellan (Merck, Whitehouse Station, NJ, USA), examinadas e fotografadas em microscópio Olympus BX60. Os osteoclastos TRAPpositivos presentes nas trabeculas da região oclusal da cripta óssea mais próximas 
ao germe dentário foram contados, Estas células foram classificadas em mononucleadas, multinucleadas (até 4 núcleos), ou gigantes (a partir de 5 núcleos). Também foram classificadas quanto à sua atividade (ativo ou inativo/latente); os osteoclastos foram considerados ativos quando aderidos à superfície óssea na qual houvera a presença de lacuna de reabsorção, e considerados inativos/latentes quando arredondados e distantes das superfícies ósseas. A análise estatística dos dados foi realizada através do Student's $T$ test.

\subsection{Microscopia eletrônica de varredura}

Foram analisados através em microscopia eletrônica de varredura os primeiros molares superiores e hemimandíbulas de animais controles, tratados com alendronato e etidronato com 14 e 28 dias de idade. Os espécimes foram fixados em solução Karnowsky modificada, sendo submetidos a 5 minutos de irradiação de microondas. Em seguida, foram lavados em água destilada, tratados com hipoclorito de sódio a $2 \%$ durante 3 períodos de 10 minutos sob agitação ultrasônica no aparelho Branson 1210 para remoção do material orgânico. Foram subsequentemente lavados em água destilada, desidratadas em concentrações crescentes de etanol, tratadas em hexametildisilazano (HMDS) durante 10 minutos e deixados para secar no interior de uma capela com sistema exaustor. Os espécimes foram então montados em suportes de alumínio e cobertos com uma camada de aproximadamente $25 \mathrm{~nm}$ de ouro em um aparelho Balzers SDC 050 (Oerlikon Balzers, Balzers, Liechtenstein). Em seguida, foram examinados e fotografados em microscópio eletrônico de varredura LEO (LEO, Germany).

\subsection{Microscopia eletrônica de transmissão - morfologia}

Foram analisados através em microscopia eletrônica de transmissão os espécimes controles e tratados com alendronato com 4, 8, 14, 21 e 28 dias de idade, e com etidronato aos 4, 8, 14 e 28 dias de idade. Os espécimes obtidos foram fixados e descalcificados como descrito no item 4.3. Posteriormente, foram lavados em tampão cacodilato de sódio a $0,1 \mathrm{M}$ pH 7,2 durante uma hora, pós-fixados em tetróxido de ósmio a $1 \%$ na mesma solução tampão durante duas horas, desidratados em concentrações crescentes de etanol, banhados em acetona, 
infiltrados e incluídos em resina epóxica Spurr (Electron Microscopy Sciences, Hatfield, PA, USA) em formas de silicone, cuja polimerização ocorreu a $60{ }^{\circ} \mathrm{C}$ durante 72 horas em ambiente livre de umidade. Cortes de $1 \mu \mathrm{m}$ de espessura foram obtidos no micrótomo citado no item anterior com facas de vidro e corados com solução alcoólica de azul de toluidina. Foram selecionadas as regiões basal e oclusal da cripta óssea do primeiro molar superior para subsequentes cortes ultrafinos de $70 \mathrm{~nm}$ em um ultramicrótomo Leica Ultracut R (Leica, Wetzlar, Germany) utilizando-se faca de diamante (Diatome, Biel, Switzerland). Os cortes foram coletados em telas de cobre de 200 meshes, contrastadas com acetato de uranila e citrato de chumbo, examinados e fotografados em um microscópio eletrônico de transmissão JEOL 1010 (JEOL, Tokyo, Japan).

\subsection{Imunocitoquímica pós inclusão com ouro coloidal}

Foram submetidas à reação imunocitoquímica os espécimes controles e tratados com alendronato com 4, 8, 14, 21 e 28 dias de idade. Os espécimes obtidos foram fixados em solução fixadora contendo $0,1 \%$ de glutaraldeído e $4 \%$ de formaldeído (preparado a partir de paraformaldeído) em tampão cacodilato de sódio a $0,1 \mathrm{M}, \mathrm{pH} 7,2$ e descalcificados como descrito no item 4.3. Posteriormente, foram lavados em tampão cacodilato de sódio a $0,1 \mathrm{M}, \mathrm{pH} 7,2$ durante uma hora, desidratados em concentrações crescentes de etanol, infiltrados e incluídos em resina acrílica L.R. White (London Resin Company Ltd, England) em cápsulas de gelatina, cuja polimerização ocorreu a $60^{\circ} \mathrm{C}$ durante 72 horas. Cortes de $1 \mu \mathrm{m}$ de espessura foram corados com solução alcoólica de azul de toluidina. Foram selecionadas as regiões basal e oclusal da cripta óssea do primeiro molar superior para subsequentes cortes ultrafinos de $70 \mathrm{~nm}$ coletados em telas de níquel de 200 meshes com película de parlodion.

Os cortes ultrafinos em telas de níquel foram submetidos ao processo de incubação, para a marcação do anticorpo OPNy (chicken anti-rat osteopontin; AranaChavez e Nanci, 2001) ou BSP (rabbit anti-human bone sialoprotein - LF84). Os cortes foram primeiramente submetidos a bloqueio em ovalbumina a $1 \%$ em PBS $0,01 \mathrm{M}, \mathrm{pH} 7,2$, durante 20 minutos. Os espécimes foram incubados com o anticorpo primário anti-osteopontina, diluída 1:150 em PBS, durante 12 horas ou anti- 
sialoproteína óssea, diluída 1:20, durante 12 horas. As telas previamente incubadas em OPNy foram novamente bloqueadas com ovalbumina por 20 minutos $e$ incubadas com o anticorpo secundário (rabbit lgG fraction anti-chicken lgG), diluído 1:2000 em PBS durante 1 hora. Findo este tempo, foi realizada a lavagem com PBS durante 15 minutos, bloqueio durante 20 minutos e incubação com proteína A-ouro com partículas de $15 \mathrm{~nm}$ (Aurion, Netherlands) diluída 1:20 em PBS durante 30 minutos. Finalmente, as telas foram lavadas com PBS e, em seguida, com água destilada por 15 minutos. Todos os procedimentos foram executados em temperatura ambiente. O controle da especificidade da reação consistiu na incubação dos cortes diretamente com proteína A-ouro. Os cortes foram contrastados com acetato de uranila e citrato de chumbo, examinados e fotografados no microscópio eletrônico de transmissão JEOL 1010 (Arana-Chavez e Nanci, 2001).

\subsection{Imunofluorescência}

Cortes congelados de $100 \mu \mathrm{m}$ de espessura coletados sobre lâminas gelatinizadas foram inicialmente lavados com PBS 0,01M pH7,4 (três trocas de dez minutos). Após a lavagem, foram bloqueados com BSA (albumina de soro bovino) $1 \%$ em tampão PBS por 30 minutos. Os espécimes foram então incubados a $4^{\circ} \mathrm{C}$ durante uma hora nas soluções de anticorpo primário: coelho anti-osteoprotegerina (Santa Cruz Biotechnology - SC 11383), cabra anti-RANKL (Santa Cruz Biotechnology - SC 7627), e coelho anti-RANK (Santa Cruz Biotechnology - SC 9072). Após 3 lavagens com PBS, os espécimes foram bloqueados novamente com BSA $1 \%$ durante 30 minutos e em seguida incubados por 1 hora em Cy3- conjugado com o anticorpo secundário contra IgG de coelho ou de cabra (SIGMA) na diluição 1:150. Após 6 lavagens de 5 minutos com PBS e de 3 lavagens de 10 minutos com tampão citrato de sódio a 0,03M com NaCl a 0,3M (CCS), os cortes foram incubados com anticorpo anti-ácidos nucléicos Sytox ${ }^{\circledR}$ Green (Invitrogen - Molecular Probes) por 15 minutos e foram novamente lavados com CCS. Em seguida as lâminas foram montadas com lamínula utilizando Vecta Shield (Vector) como meio de montagem, acondicionadas em caixas plásticas e conservadas a $-20^{\circ}$ C. Os cortes foram previamente observados para seu reconhecimento no microscópio de fluorescência 
Zeiss Axiophot 2 (Carl Zeiss, Oberköchen, Germany). Posteriormente, foram examinados em microscópio confocal de varredura a laser modelo Zeiss Axiovert 100M LSM 510 (com fonte de mercúrio - 100W de alta pressão).

\subsection{Western Blotting}

Foi removido o teto da cripta óssea do primeiro molar de ratos tratados com alendronato aos 4, 8, 14, 21 e 28 dias de idade e de ratos controles aos 4 e 8 dias de idade. Os demais períodos de estudos foram excluídos do grupo controle devido ao fato do osso já ter sido reabsorvido na região de interesse nestes períodos, uma vez que nos nestes animais o processo eruptivo ocorre normalmente. $O$ tecido ósseo foi removido com o auxílio de um bisturi e imediatamente congelado por imersão em nitrogênio líquido. Foram removidas amostras de oito animais por grupo. As amostras foram armazenadas em nitrogênio líquido até o momento da extração de proteínas.

Previamente à extração de proteínas das amostras, os fragmentos ósseos foram triturados até se reduzirem a pó sob refrigeração. Em seguida, foram transferidos para um gral de porcelana ao qual foram adicionados $10 \mu \mathrm{L}$ de inibidor de protease e $1 \mathrm{~mL}$ de tampão de lise contendo $\mathrm{KCl}$ a $100 \mathrm{mM}$ + Hepes a $10 \mathrm{mM}$ + $\mathrm{MgCl}$ a $3 \mathrm{mM}$ + EDTA a $5 \mathrm{mM}$ + DTT a $1 \mathrm{mM}$ + SDS a $10 \%$ e Glicerol a $10 \%$, e macerados vigorosamente até a obtenção de um líquido homogêneo. O lisado foi em seguida centrifugado a $10000 \mathrm{rpm}$ a $4{ }^{\circ} \mathrm{C}$ durante 10 minutos, e o sobrenadante obtido foi aliquotado e estocado a $-80^{\circ} \mathrm{C}$.

As proteínas foram quantificadas com 0 kit Quant-it ${ }^{\circledR}$ protein assay da Invitrogen de acordo com a metedologia recomendada pelo fabricante. Os preparados foram anallisados na plataforma de quantificação Qubit ${ }^{\circledR}$ da Invitrogen (Life Technologies, Carlsbad, CA, USA).

As alíquotas do sobrenadante foram misturadas com tampão de amostra para concentração final de $1 \mathrm{X}$, contendo $20 \mu \mathrm{g}$ de proteína total. Em seguida, foram 
aquecidas a $100^{\circ} \mathrm{C}$ durante 5 minutos e então submetidas a SDS-PAGE, sendo feita eletroforese a $100 \mathrm{~V}$ por 180 minutos, em gel de acrilamida a 10\%. O padrão de peso molecular utilizado foi o Full range Rainbow ${ }^{\circledR}$ (Amersham Pharmacia Biotech, Aylesbury, UK).

A transferência das proteínas para a membrana de nitrocelulose foi feita por eletrotransferência semi-seca num dispositivo Amersham mini VE ${ }^{\circledR}$ (Amersham Pharmacia Biotech, Aylesbury, UK). utilizando para tal tampão de transferência (250 mM Tris-Base; 1,92 mM Glicina, 20\% Metanol; pH 8,3). A transferência foi realizada com $30 \mathrm{~V}$ por 180 minutos. Após a transferência, a membrana foi submetida à fase de bloqueio ou lavada e seca para posterior reação.

Para a imunoreação, foi feito bloqueio dos sítios inespecíficos com $5 \%$ de leite desnatado em TTBS (tampão TRIS com adição de Tween a 0,01\%), por 1 hora em temperatura ambiente, sob agitação. Em seguida, a solução de bloqueio foi removida lavando-se a membrana com TTBS. A membrana foi incubada durante 2 horas à temperatura ambiente e sob agitação, com os anticorpos rabbit anti-RANK (Santa Cruz Biotechnology, Santa Cruz, California, USA), rabbit anti-RANKL (Santa Cruz) e rabbit anti-OPG (Santa Cruz) na concentração de 1:200 e anti-actina (Sigma, St Louis, MO, USA) na concentração 1:1000. Seguiram duas lavagens com TTBS para remoção do anticorpo não-absorvido e duas lavagens com TBS sob agitação e à temperatura ambiente, seguido de incubação por 2 horas com anticorpo secundário (horseradish peroxidase-linked anti-rabbit IgG 1:1000, Amersham Pharmacia Biotech, Aylesbury, UK) diluído em solução de bloqueio. A imunoreatividade foi detectada através do kit ECL ${ }^{\text {TM }}$ (GE Healthcare, UK), seguindo recomendações do fabricante.

\subsection{Cultura de células RAW-264.7}

Células da linhagem RAW 264.7 (ATCC, Manassas, VA, USA) foram cultivadas em placas de 24 wells em meio Dulbecco's modified essential medium DMEM (Fischer) suplementado com 10\% de soro fetal bovino, 0,25\% de penicilina, $1 \%$ de L-glutamina e RANKL recombinante (Hurst et al, 2004) acrescido de alendronato sódico a $1 \mu \mathrm{M}$ e $10 \mu \mathrm{M}$ diluídos em PBS $0,01 \mathrm{M}$ pH 7,2 ou somente PBS, 
e foram feitas trocas de meio a cada 2 dias. Os controles tiveram o meio trocado nos mesmos períodos, sem adição de alendronato. Ao quinto dia, foi feito o ensaio histoquímico para identificação da TRAP utilizando-se o Acid Phosphatase Leucocyte (TRAP) kit (Sigma, St Louis, MO, USA), seguindo recomendações do fabricante, a fim de confirmar o surgimento dos osteoclastos. O número de células TRAP positivas mononucleadas, multinucleadas (apresentando 2 a 4 núcleos) e gigantes (apresentando 5 ou mais núcleos) foi contado. O teste estatístico utilizado para comparar os grupos entre si foi o student's $T$ test.

\subsection{Cultura de células da medula óssea de camundongos}

Para obtenção das células para a cultura primária foram utilizados 10 camundongos Swiss-Webster com 4 semanas de idade. Eles foram sacrificados por deslocamento cervical, as tíbias e os fêmures foram dissecados e as extremidades epifisárias removidas. As células foram obtidas a partir da medula óssea, a qual foi expelida do canal medular injetando-se meio essencial mínimo a-modificado ( $\alpha$ MEM) adicionado de $10 \%$ de soro fetal bovino com uma agulha de 25 gauges. As células foram lavadas duas vezes e plaqueadas em densidade de $1 \times 10^{6}$ sobre discos de osso cortical bovino com $1 \mathrm{~cm}^{2}$ e $100 \mu \mathrm{m}$ de espessura, em placas de 24 wells, em meio $\alpha$-MEM D10 suplementado com 1,25-dihidroxivitamina $D_{3}$ a $10^{-8} \mathrm{M}$. O meio foi acrescido de alendronato sódico nas doses de $10 \mu \mathrm{M}, 1 \mu \mathrm{M}, 100 \mathrm{nM}, 10 \mathrm{nM}$, 1nM diluídos em PBS a 0,01M pH 7,2 ou somente PBS, e foram feitas trocas de meio a cada 2 dias (Holliday et al., 1995).

Ao quinto dia, os discos de osso foram transferidos para uma nova placa de 24 wells, tratadas com SDS a $2 \%$, enxaguadas em água deionizada, desidratadas em concentrações crescentes de etanol, recobertas com ouro e examinadas em microscópio eletrônico de varredura JEOL JSM 6200 (JEOL, Tokyo, Japan). Nas células remanescentes na placa foi feito o ensaio histoquímico como mencionado no item anterior, para identificação da TRAP a fim de confirmar o surgimento dos osteoclastos. O número de células TRAP positivas mononucleadas, multinucleadas (2 a 4 núcleos) e gigantes (5 ou mais núcleos) foi contado. O teste estatístico utilizado para comparar os grupos entre si foi o student's T test. 
5 RESULTADOS 


\subsection{Aspectos morfológicos}

\subsubsection{Grupo controle}

Aos quatro dias de vida, os primeiros molares superiores dos animais encontravam-se na fase de campânula tardia da odontogênese. O germe dentário apresentou-se rodeado pelo folículo dentário, separando-o do osso alveolar da cripta. Alguns osteoclastos estavam aderidos às trabéculas ósseas que rodeavam o germe dentário. Estruturas do germe dentário como o órgão do esmalte, a papila dentária e a região da alça cervical apresentaram-se intactos, com morfologia típica deste estágio do desenvolvimento dental (Figura 1). Analisando cortes incubados pelo método histoquímico para detecção da enzima TRAP, observamos que os osteoclastos TRAP-positivos se encontravam distribuídos por toda a cripta, inclusive nas regiões do teto e da base (Figura 2).

Aos oito dias de idade, os animais controle apresentaram osteoclastos multinucleados e TRAP-positivos distribuídos em diversas áreas da cripta óssea, aderidos às trabéculas ósseas. Neste período, pode-se observar que uma parte da porção oclusal da cripta já fora reabsorvida, implicando que a formação da via eruptiva estava ocorrendo (Figura 3 ).

Em uma fase mais avançada, no décimo quarto dia, a maturação do esmalte da coroa encontrava-se em estágio avançado, observando-se ainda a matriz orgânica deste tecido na porção cervical da coroa; nesse estágio, a deposição de dentina coronária ainda estava acontecendo, enquanto que a dentina radicular estava sendo formada (Figura 4). Observaram-se numerosos osteoclastos TRAPpositivos no osso da porção oclusal da cripta, que pareciam reabsorver a matriz mineralizada de modo a formar a via eruptiva. Em maior aumento, observou-se que não há aparente presença de matriz óssea nessa região, a qual supostamente fora removida pelas células TRAP-positivas presentes no local (Figura 5). 
Aos vinte e um dias, o primeiro molar superior dos controles encontrava-se na fase de penetração da mucosa da erupção dentária. $O$ ápice da raiz estava quase completamente formado (Figura 6), e havia grande quantidade de osteoclastos na base a cripta e região do septo alveolar.

Aos trinta dias, a coroa do primeiro molar já alcançara o plano oclusal funcional. A raiz e o periodonto de inserção estavam bem desenvolvidos, porém ainda não fora observado o fechamento do ápice radicular (Figura 7). Alguns osteoclastos TRAP-positivos foram observados nas áreas de osso alveolar em remodelação em torno do ápice radicular que completava sua formação (Figura 8). 
Figura 1 - Grupo controle, 4 dias.
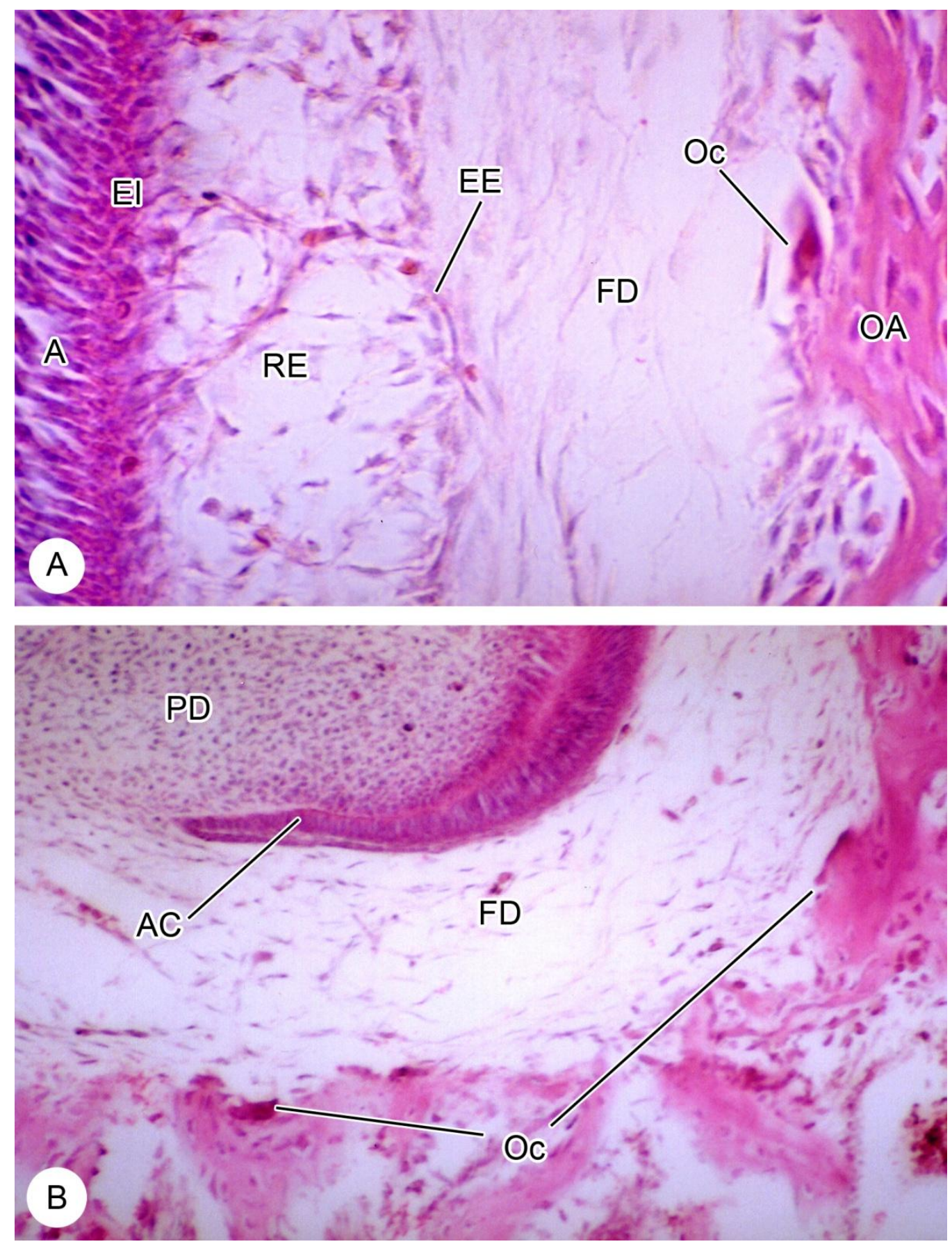

Em A, micrografia ilustrando a relação entre o germe dentário e o osso alveolar da cripta. O órgão do esmalte do germe dentário, constituído por ameloblastos (A), estrato intermediário (EI), retículo estrelado (RE) e epitélio externo (EE) é circundado pelo folículo dentário (FD). Observa-se no osso alveolar da cripta $(\mathrm{AO})$ um osteoclasto. Em B, é ilustrada a região da alça cervical do germe dentário (AC). Notar que o folículo dentário ao redor proporciona certa distância entre o germe dentário e o osso alveolar da base da cripta. Aumento: A, 400X; B, 100X. Coloração HE. 
Figura 2 - Grupo controle, 4 dias. TRAP.
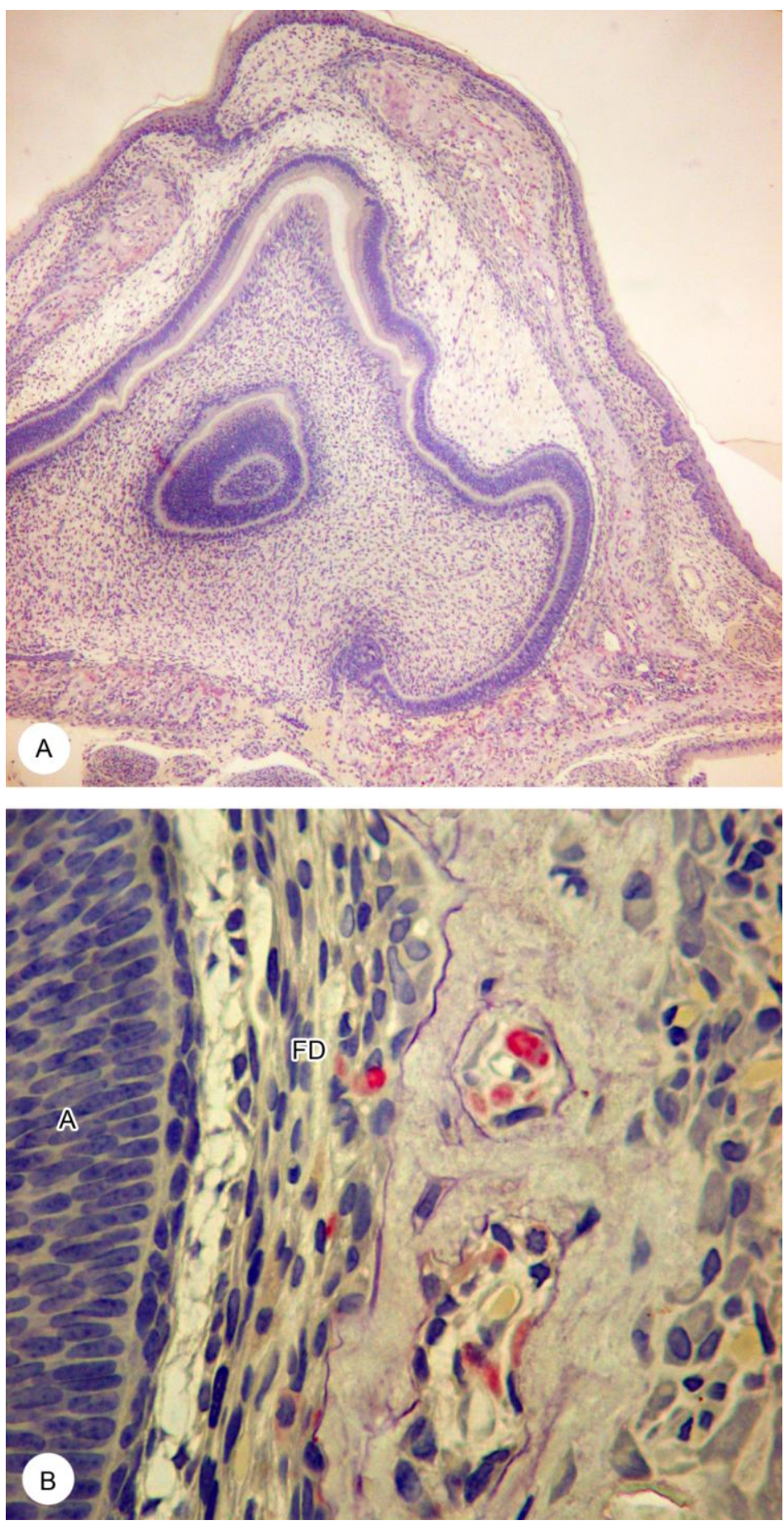

Em A, observa-se o germe do primeiro molar em corte incubado pelo método histoquímico TRAP. Os osteoclastos TRAP positivos (em vermelho) são observados nas paredes da cripta, havendo maior concentração na base e no teto. Em B, Observa-se em maior detalhe células TRAP positivas mononucleadas próximas às trabéculas ósseas. A, ameloblastos. FD, folículo dentário. Histoquímica TRAP. Contra coloração: hematoxilina. Aumento: A, 25X; B, 400X. 
Figura 3 - Grupo controle, 8 dias. TRAP.
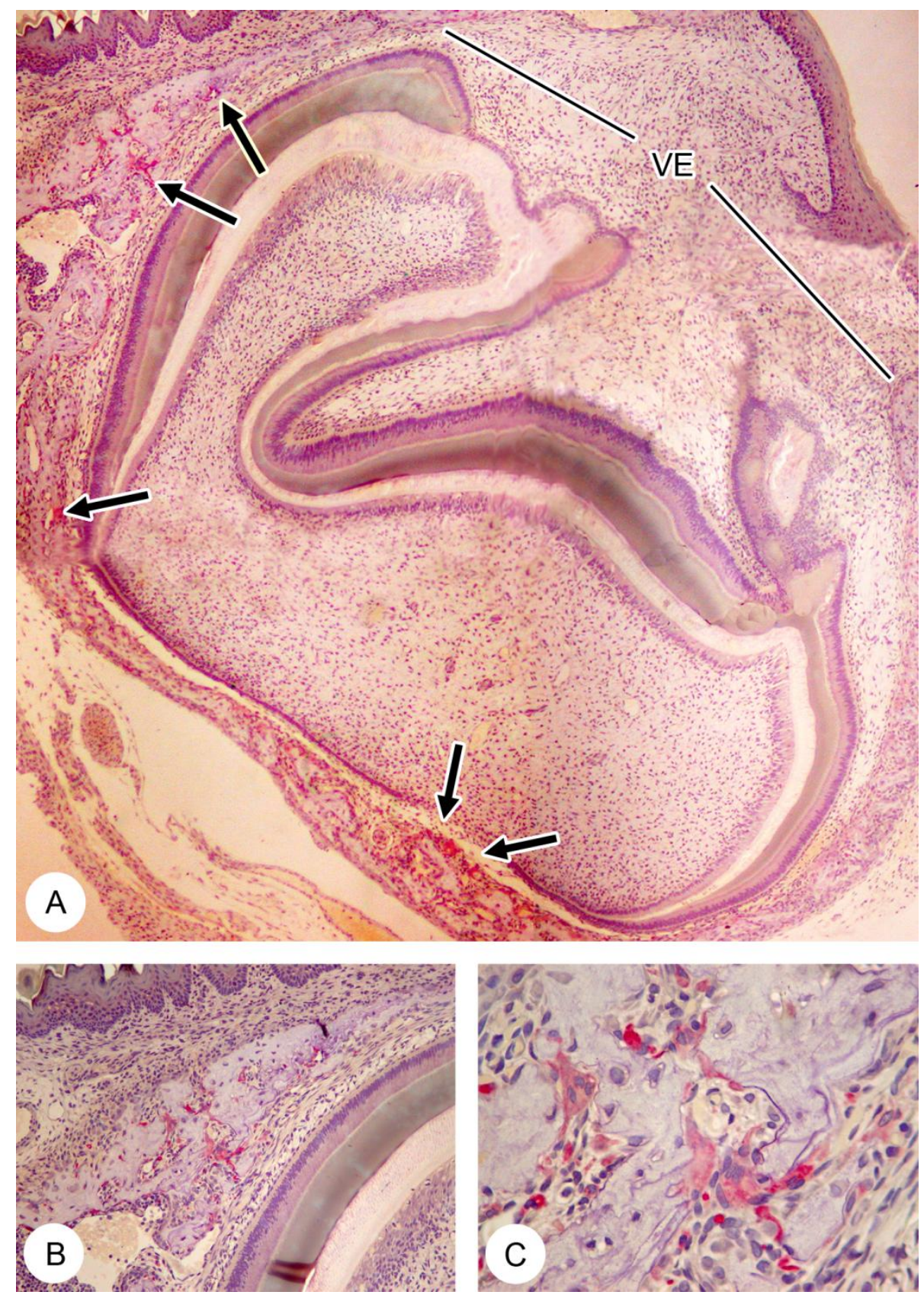

Em A, observa-se o germe do primeiro molar em uma etapa mais avançada de seu desenvolvimento. A cripta óssea apresenta osteoclastos TRAP-positivos (em vermelho) aderidos às trabéculas (setas). Na porção oclusal, observar a ausência de tecido em uma considerável extensão, durante a formação da via eruptiva. Em B e C, observam-se em maior detalhe os osteoclastos reabsorvendo a porção oclusal da cripta. A, 20X; B, 25X; C, 100X. 
Figura 4 - Grupo controle, 14 dias.
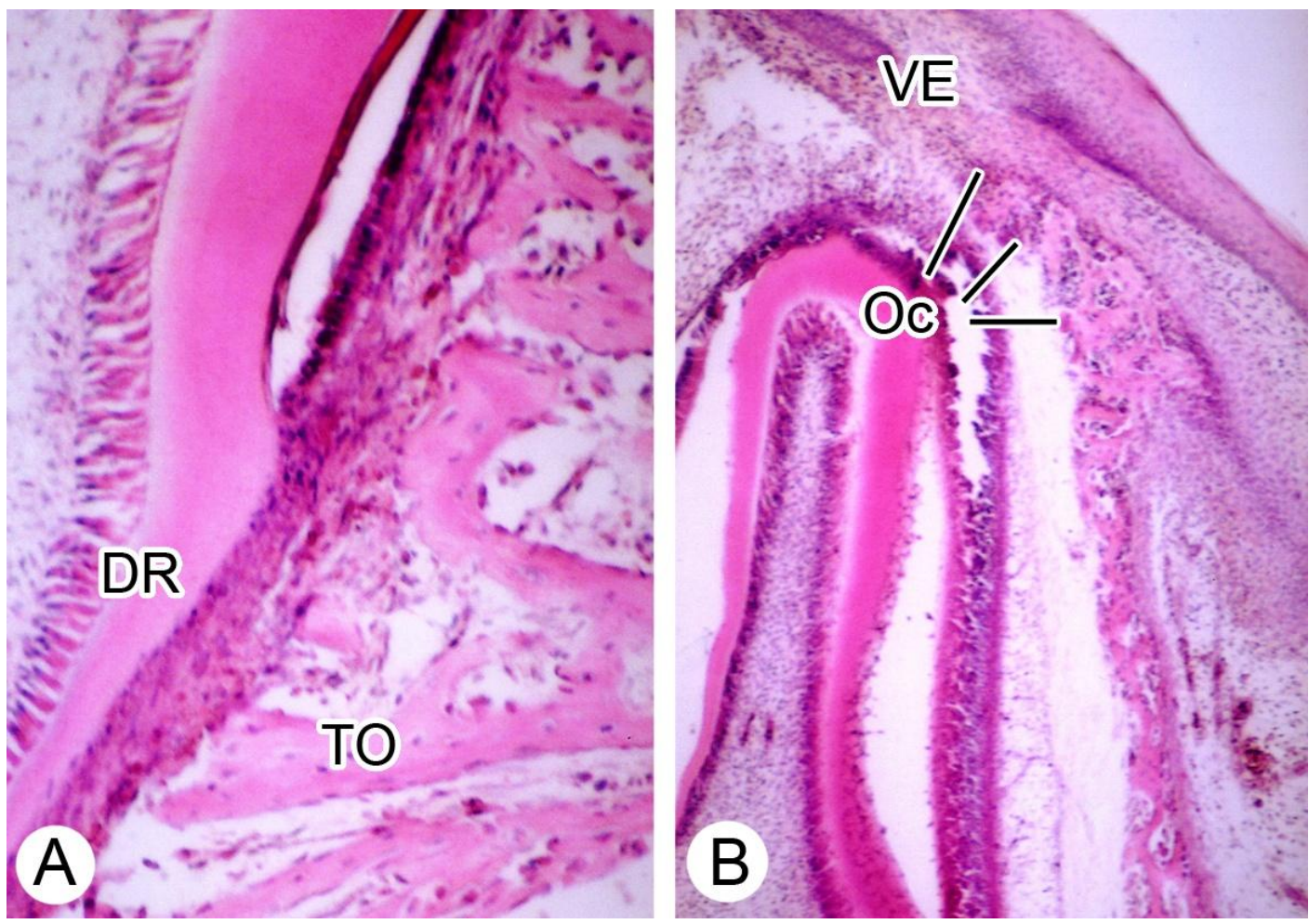

Em A, é ilustrada a porção cervical do primeiro molar, onde se observa uma porção da dentina radicular e o periodonto de inserção em formação. TO, trabéculas ósseas. DR, dentina radicular. Em B, a porção oclusal da cripta é ilustrada. Observa-se a via eruptiva (VE) estabelecida, e osteoclastos (Oc) reabsorvendo o tecido ósseo do teto da cripta. A, 100X; $\mathrm{B}$, 40X. 
Figura 5 - Grupo controle, 14 dias. TRAP.

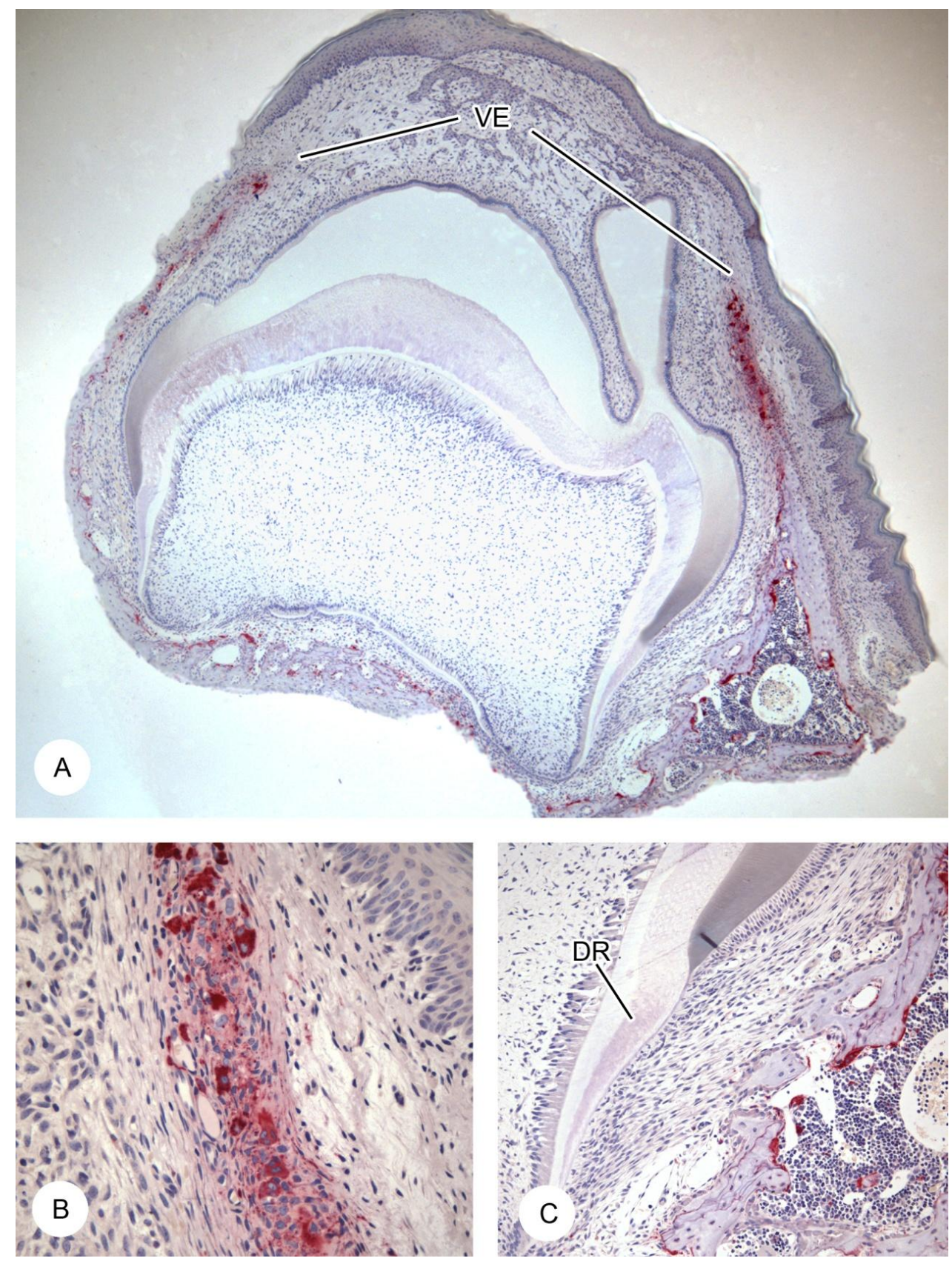

Em A, observam-se numerosas células TRAP-positivas (em vermelho) na região ocluso-lateral da cripta óssea, onde a via eruptiva (VE) está quase totalmente estabelecida. Em B, observam-se em maior detalhe os osteoclastos em meio a um material extracelular que provavelmente é constituído por remanescentes da matriz óssea recém-reabsorvida. Em C, observam-se algumas células TRAP-positivas no osso alveolar do periodonto em desenvolvimento ao redor das raízes em formação do primeiro molar. A, 20X; B e C, 100X. 
Figura 6 - Grupo controle, 21 dias. TRAP.
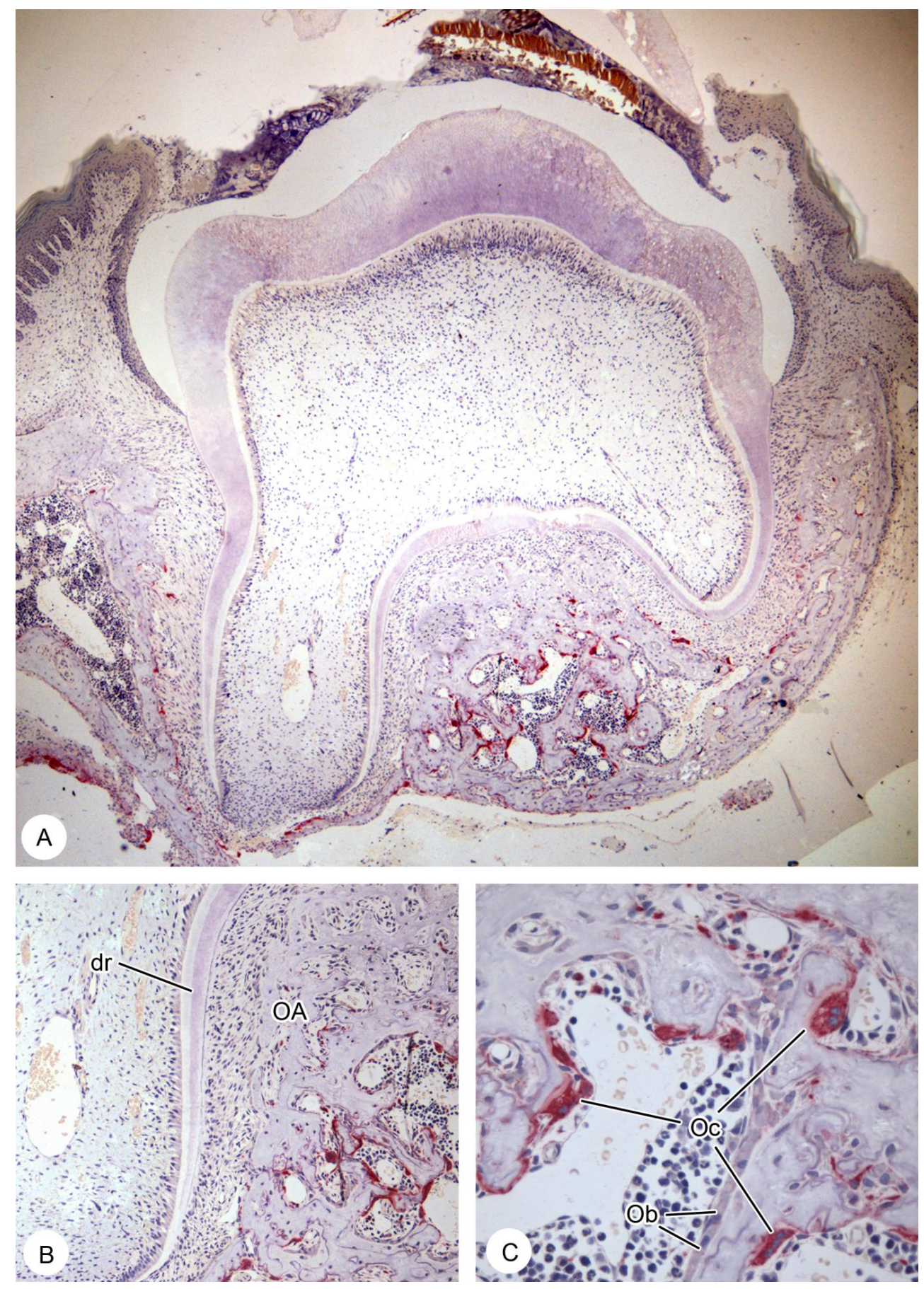

Em A, é ilustrado o primeiro molar apresentando a coroa parcialmente erupcionada. Observam-se osteoclastos TRAP-positivos (em vermelho) nas superfícies do osso alveolar voltadas para a raiz do dente, e nas trabéculas ósseas da região do septo alveolar. Em B, observa-se a dentina radicular (dr) em formação e o osso alveolar (OA) do periodonto. Em C, observam-se na região do septo alveolar diversos osteoclastos ativados (Oc) e osteoblastos (Ob). A, 20X; B, 100X; C, 200X. 
Figura 7 - Grupo controle, 30 dias.
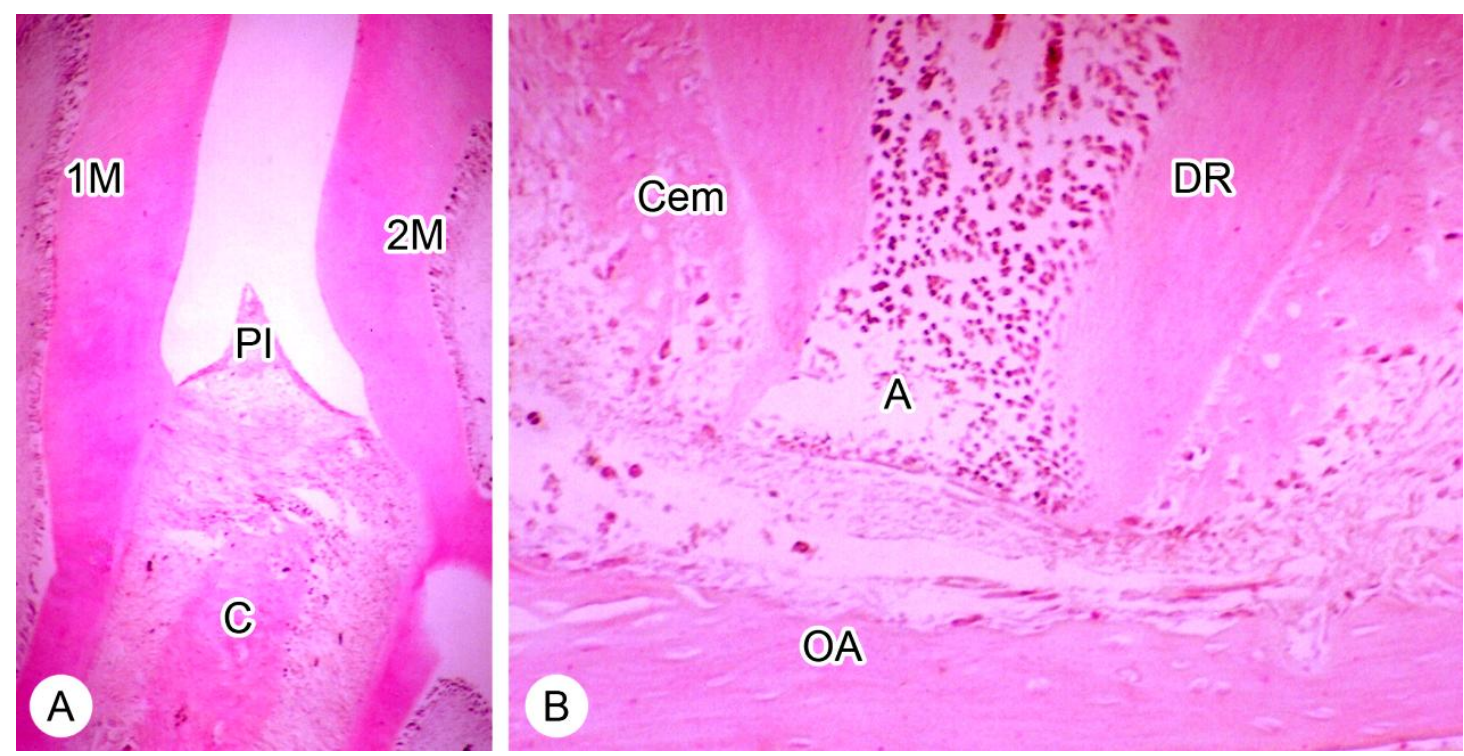

Em A, são ilustrados o primeiro (1M) e o segundo (2M) molares superiores cujas coroas estão erupcionadas. PI, papila interdental. C, crista alveolar. Em B, observa'se o ápice radicular (A) quase totalmente formado, a dentina radicular (DR) e o cemento celular (Cem) do periodonto de inserção revestindo a dentina. OA, osso alveolar. A, 40X; B, 100X. 
Figura 8 - Grupo controle, 28 dias. TRAP.
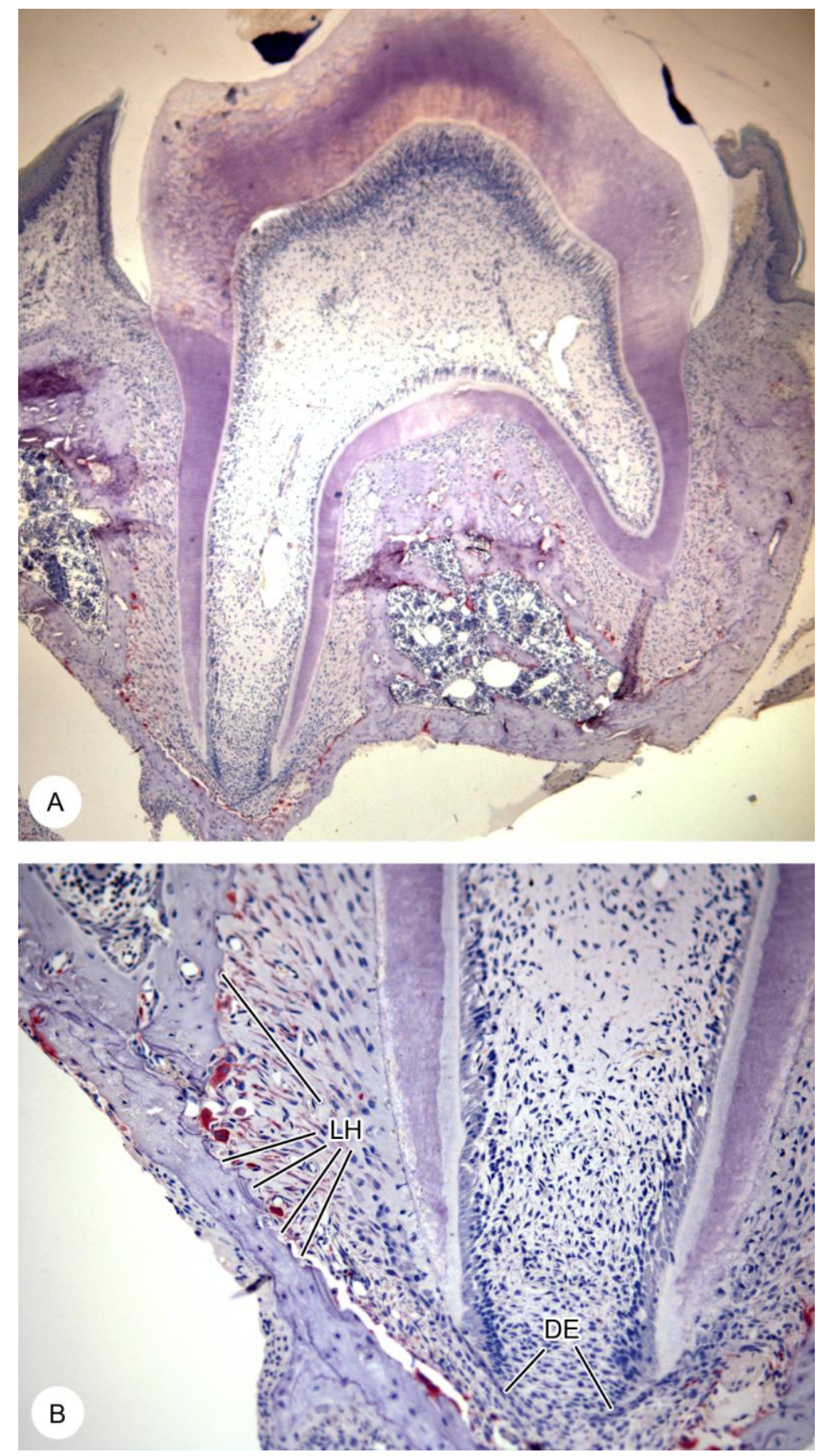

Em A, observa-se a distribuição dos osteoclastos TRAP-positivos no osso alveolar do periodonto, no qual estão ancoradas as raízes do primeiro molar. Os osteoclastos aparecem aderidos às superfícies do alvéolo voltadas para o ligamento periodontal, na região apical e no septo alveolar. Em B, observam-se diversas lacunas de Howship (LH) no osso alveolar da região apical, onde se observa o diafragma epitelial (DE) ainda em proliferação. A, 20X; B, 100X. 
5.1.2 Grupo tratado com alendronato sódico

Aos quatro dias de vida, o folículo dentário ao redor do germe do primeiro molar apresentou descontinuidade devido a algumas finas trabéculas ósseas crescerem a partir das paredes da cripta em direção ao germe dentário, e estabelecerem contato com o órgão do esmalte em diversos pontos, principalmente na região da alça cervical (Figura 9). Apesar do aspecto desorganizado do crescimento das trabéculas ósseas, foram observadas algumas células multinucleadas e TRAP-positivas (Figura 10).

Os animais tratados com alendronato aos oito dias de idade também apresentaram osteoclastos TRAP-positivos arredondados, aparentemente não polarizados, distribuídos pelo osso da cripta, porém afastados das superfícies trabeculares (Figura 11).

Aos catorze dias, as trabéculas ósseas ao redor do germe dentário dos animais tratados com alendronato aumentaram e estabeleceram contato com diversas estruturas do folículo e do germe dentário. O diafragma epitelial e a bainha epitelial de Hertwig encontraram-se desorganizados. As trabéculas ósseas estavam muito próximas do germe dentário em diversas regiões, em contato com a superfície do esmalte em algumas áreas, ocasionando defeitos. Foram observadas diversas áreas de anquilose (Figura 12). Nesta fase, não foram observados osteoclastos aderidos ao osso em toda a extensão da cripta, indicando ausência de formação da via eruptiva, bem como de remodelação das paredes da cripta óssea. Os osteoclastos TRAP-positivos presentes no osso alveolar continuaram a apresentar o mesmo aspecto descrito anteriormente, em estado latente (Figura 13).

Aos vinte e um dias, os animais tratados, apresentaram numerosos osteoclastos latentes distribuídos ao longo de todo o osso alveolar ao redor do primeiro molar incluso, e foram observadas trabéculas ósseas na região oclusal da cripta. Na região cervical, observou-se uma curta deposição de dentina radicular; 
entretanto, algumas trabéculas ósseas foram depositadas na região muito próxima a esta dentina. Os numerosos osteoclastos apresentaram as mesmas características dos animais tratados descritas anteriormente (Figura 14).

Aos trinta dias, foi observada continuidade do epitélio da mucosa oral com o epitélio reduzido do esmalte; entretanto, a coroa permanecera impactada no interior da cripta óssea, e não foi observada formação radicular. O molar continuou incluso no processo alveolar da maxila, apresentando numerosas trabéculas ósseas sobre sua face oclusal (Figura 15). Ainda puderam ser observadas diversas áreas de anquilose e numerosos osteoclastos latentes TRAP-positivos (Figura 16). 
Figura 9 - Grupo tratado com alendronato, 4 dias.
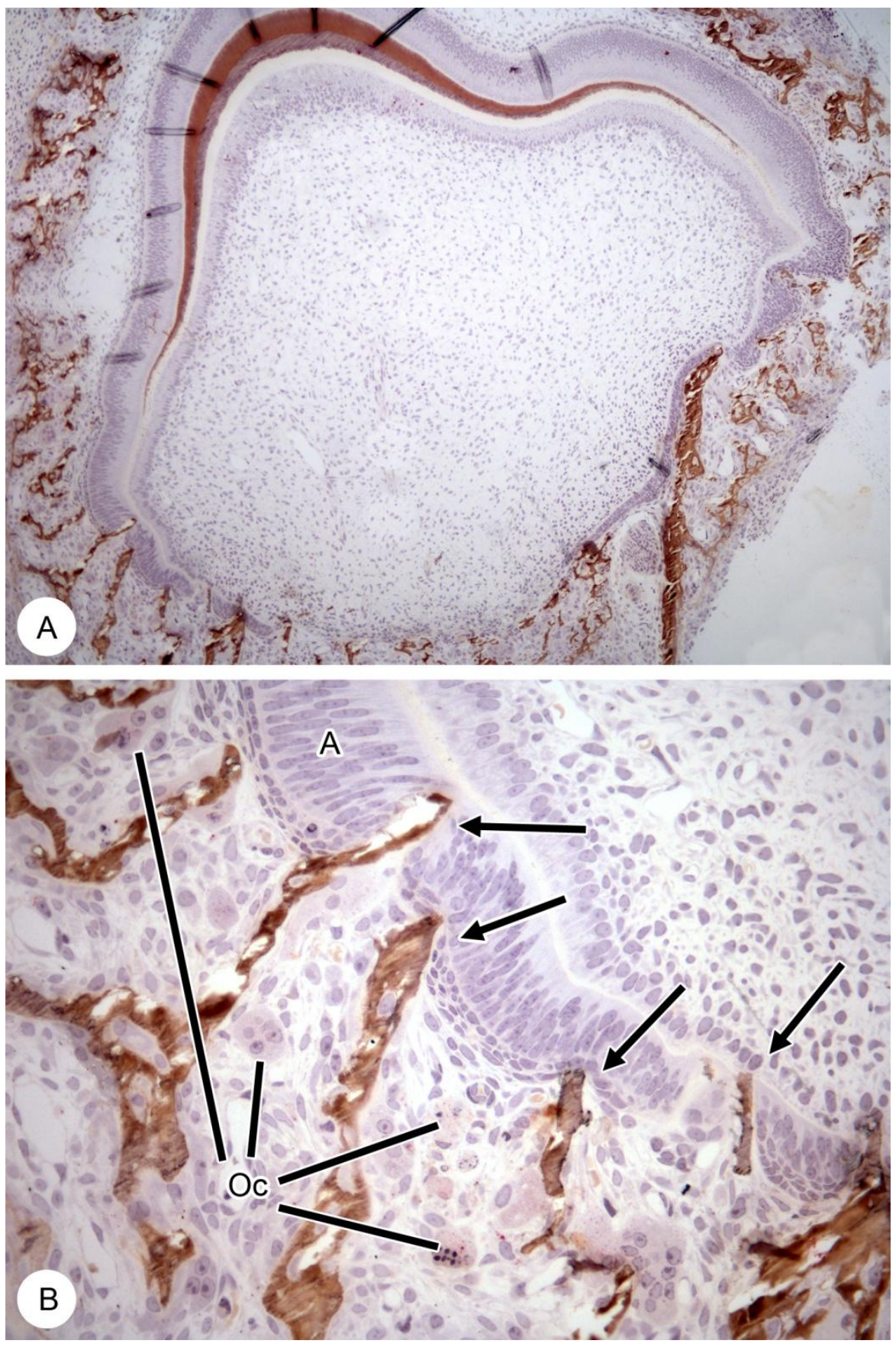

Em A, é ilustrado o germe do primeiro molar no interior da cripta óssea. Neste grupo, foi o notado o contato entre o órgão do esmalte do germe dentário e diversas trabéculas ósseas em desenvolvimento. Em B, observam-se em maior detalhe estes contatos (setas). Alguns osteoclastos (Oc) são observados entre as trabéculas ósseas. Material não descalcificado, corado com hematoxilina. A, ameloblastos. A, 25X; B, $100 \mathrm{X}$ 
Figura 10 - Grupo tratado com alendronato, 4 dias. TRAP
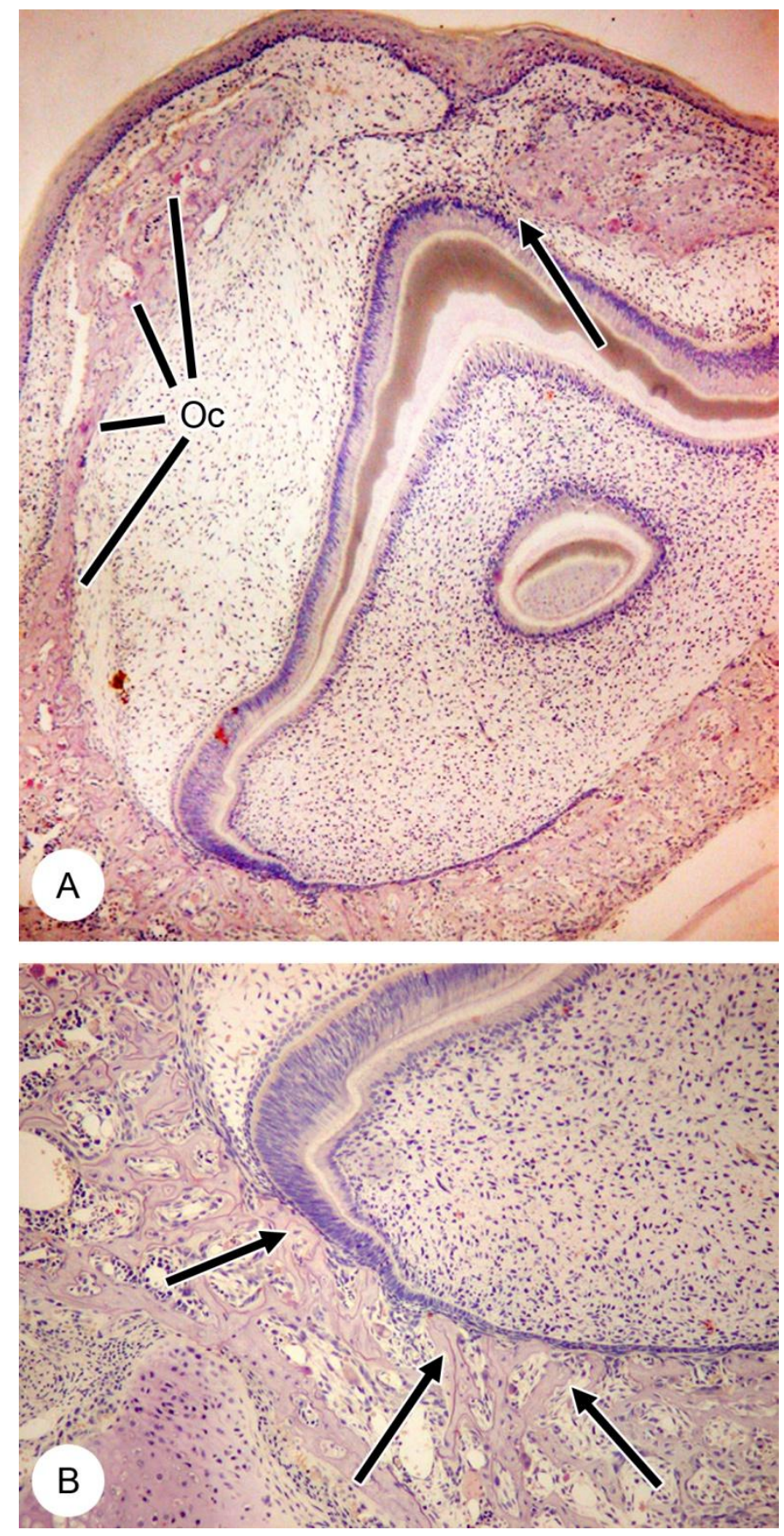

Em A, osteoclastos TRAP positivos (Oc) são observados no osso alveolar ao redor do germe dentário. Na região ocusal se observa uma trabécula óssea no espaço do folículo dentário (seta), muito próxima aos ameloblastos. Em $B$, contato entre muitas trabéculas ósseas e a região lateral e alça cervical do germe dentário (setas). A, 25X, B, 40X. 
Figura 11 - Grupo tratado com alendronato, 8 dias. TRAP.
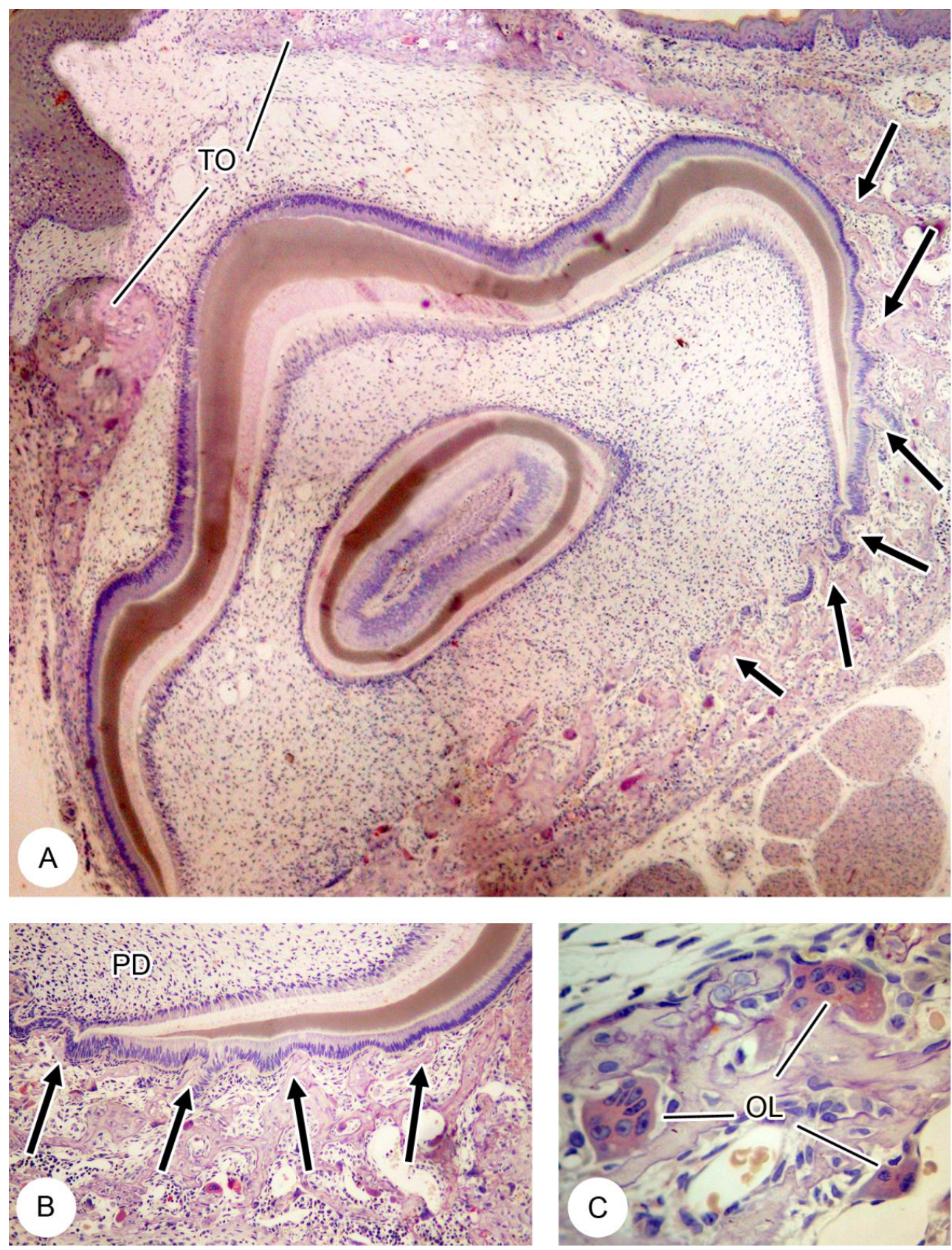

Em A, fotomicrografia mostrando o primeiro molar, e trabéculas ósseas (TO) na região oclusal da cripta. Observa-se um espaço entre os bordos ósseos, mostrando que nesta etapa do processo de erupção dentária há cominucação entre o órgão do esmalte e o epitélio oral. Na porção lateral do germe dentário, assim como na alça cervical, são observados contatos de trabéculas ósseas com o folículo dentário e as células epiteliais em diversos pontos (setas). $\mathrm{Em} \mathrm{B}$, isto é observado em maior detalhe. Em C, osteoclastos latentes (OL) TRAP-positivos são observados entre as trabéculas ósseas. A, 20X; B, 40X, C, 400X. 
Figura 12 - Grupo tratado com alendronato, 14 dias.

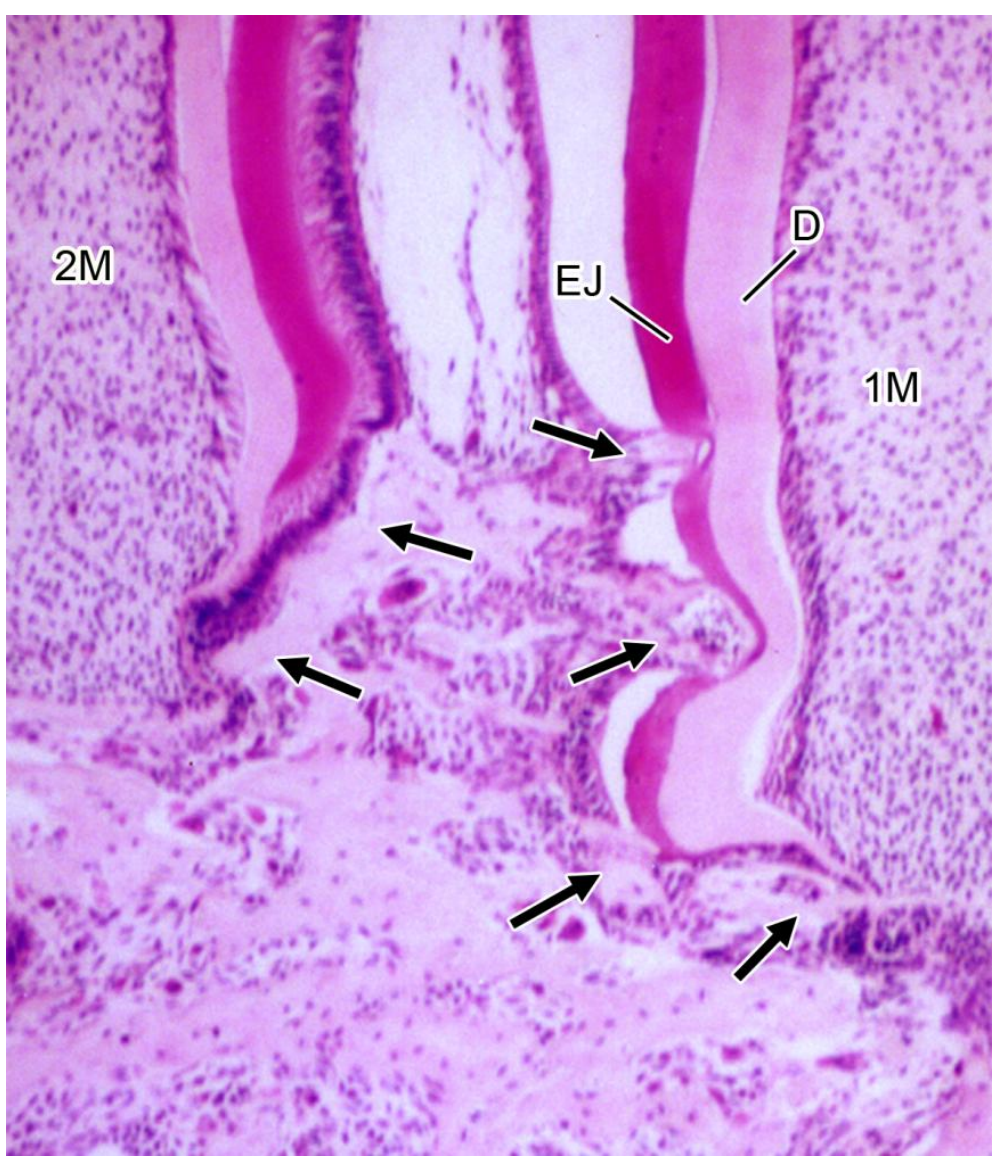

Fotomicrografia mostrando o primeiro (1M) e o segundo molares (2M) cortados sagitalmente. Observar as trabéculas ósseas em contato com o esmalte jovem (EJ) do primeiro molar e as células epiteliais na região cervical do germe do primeiro e segundo molares (setas). D, dentina. $100 X$. 
Figura 13 - Grupo tratado com alendronato, 14 dias. TRAP.
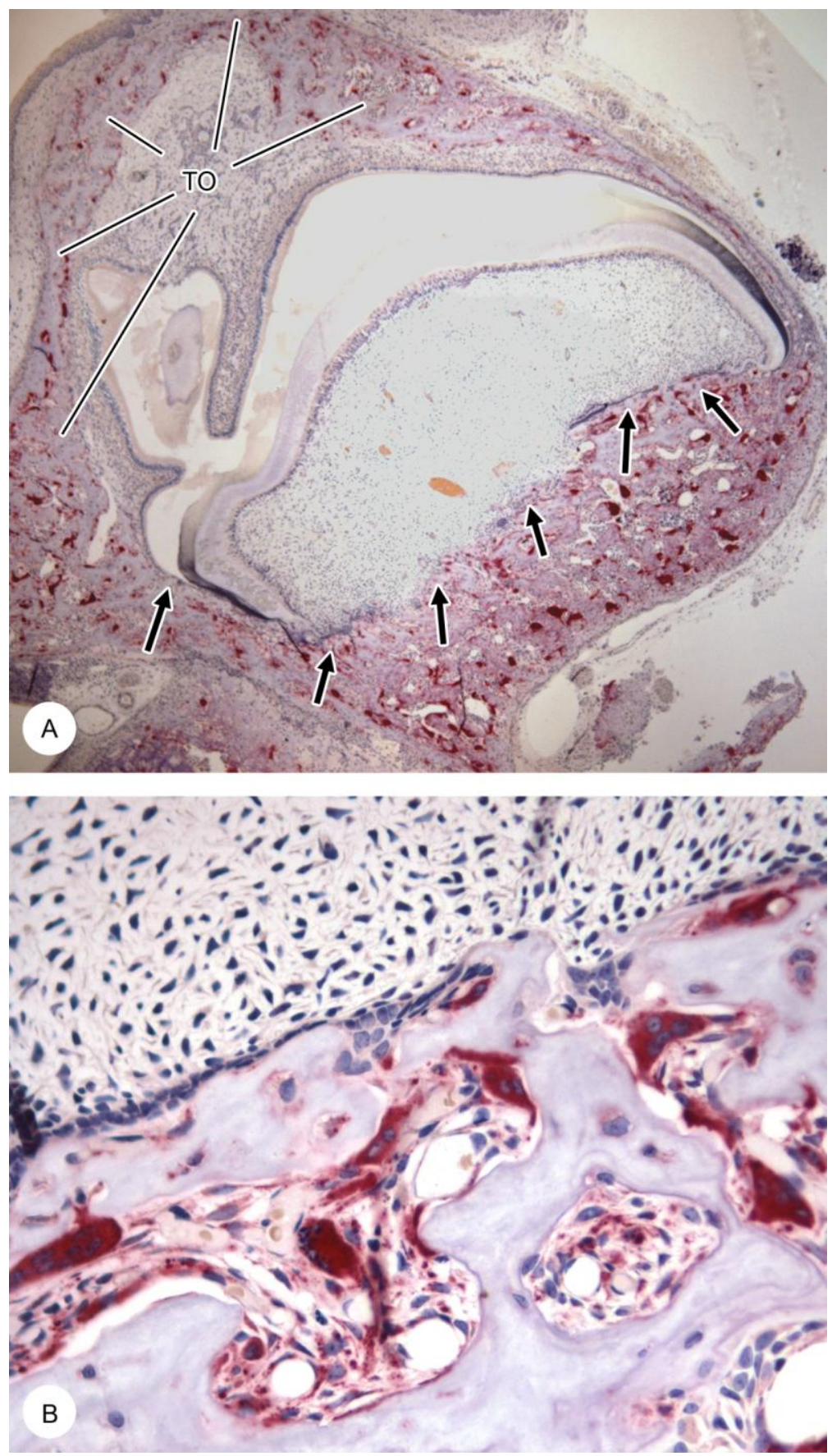

Em $A$, é ilustrado o germe do primeiro molar rodeado por trabéculas ósseas da cripta óssea. Observar a presença de numerosos osteoclastos TRAP-positivos em todas as regiões da cripta, e trabéculas ósseas (TO) recobrindo a porção oclusal do germe dentário. Nas porções lateral e basal, trabéculas ósseas tocam o germe dentário em diversos pontos (setas). Em B, nota-se que diversos osteoclastos na base da cripta apresentam-se latentes, afastados das trabéculas, e alguns parecem estar aderidos a elas. A, 20X, B, 400X. 
Figura 14 - Grupo tratado com alendronato, 21 dias. TRAP.
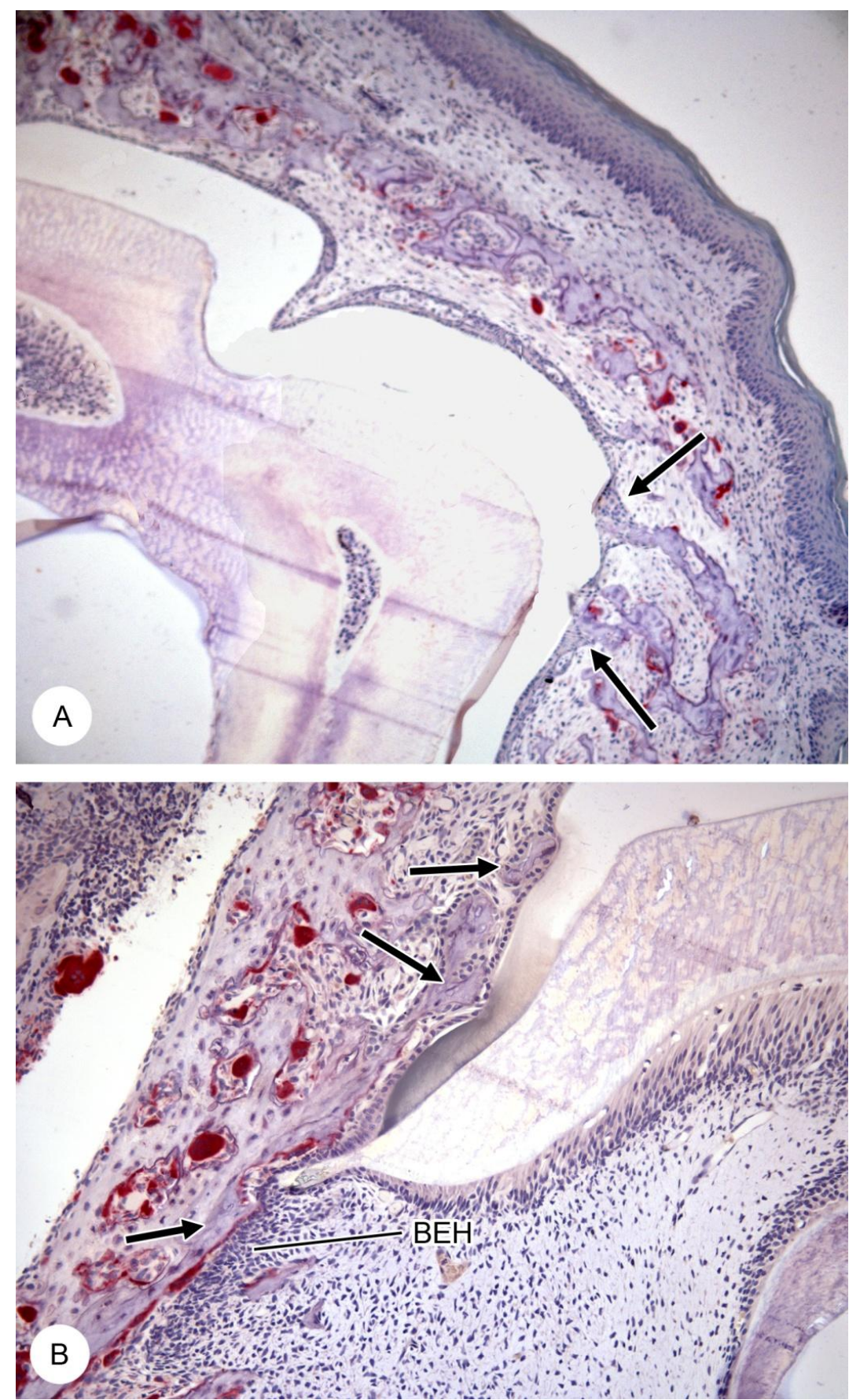

A ilustra a porção oclusal do germe do primeiro molar recoberta por trabéculas ósseas. Notar a presença de alguns osteoclastos TRAPpositivos entre as trabéculas. Algumas trabéculas parecem estar em contato com o espaço do esmalte (setas). Em B, trabéculas ósseas em contato com o esmalte na porção cervical da coroa, e com a bainha epitelial de Hertwig (BEH) (setas). A e B, 40X 
Figura 15 - Grupo tratado com alendronato, 30 dias.
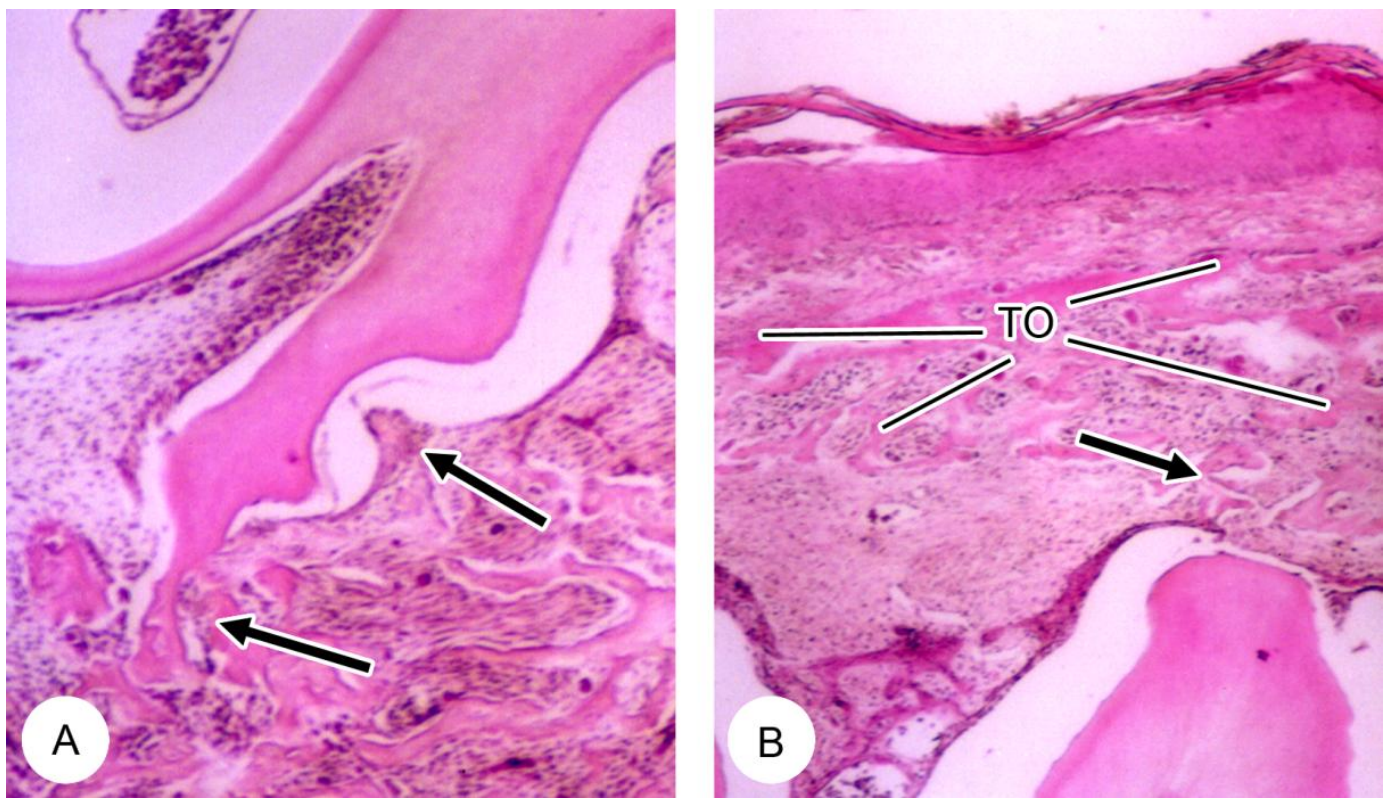

Em A, é mostrada parte do germe do primeiro molar que permaneceu impactado no interior da cripta óssea. Observar regiões de anquilose da coroa, onde trabéculas ósseas parecem invadir a região correspondente ao esmalte (setas). Notar a ausência de formação radicular. Em B, trabéculas ósseas recobrem a porção oclusal do primeiro molar, sendo observados contatos com a área livre de esmalte de uma cúspide (seta). A e $B, 40 X$. 
Figura 16 - Grupo tratado com alendronato, 28 dias. TRAP
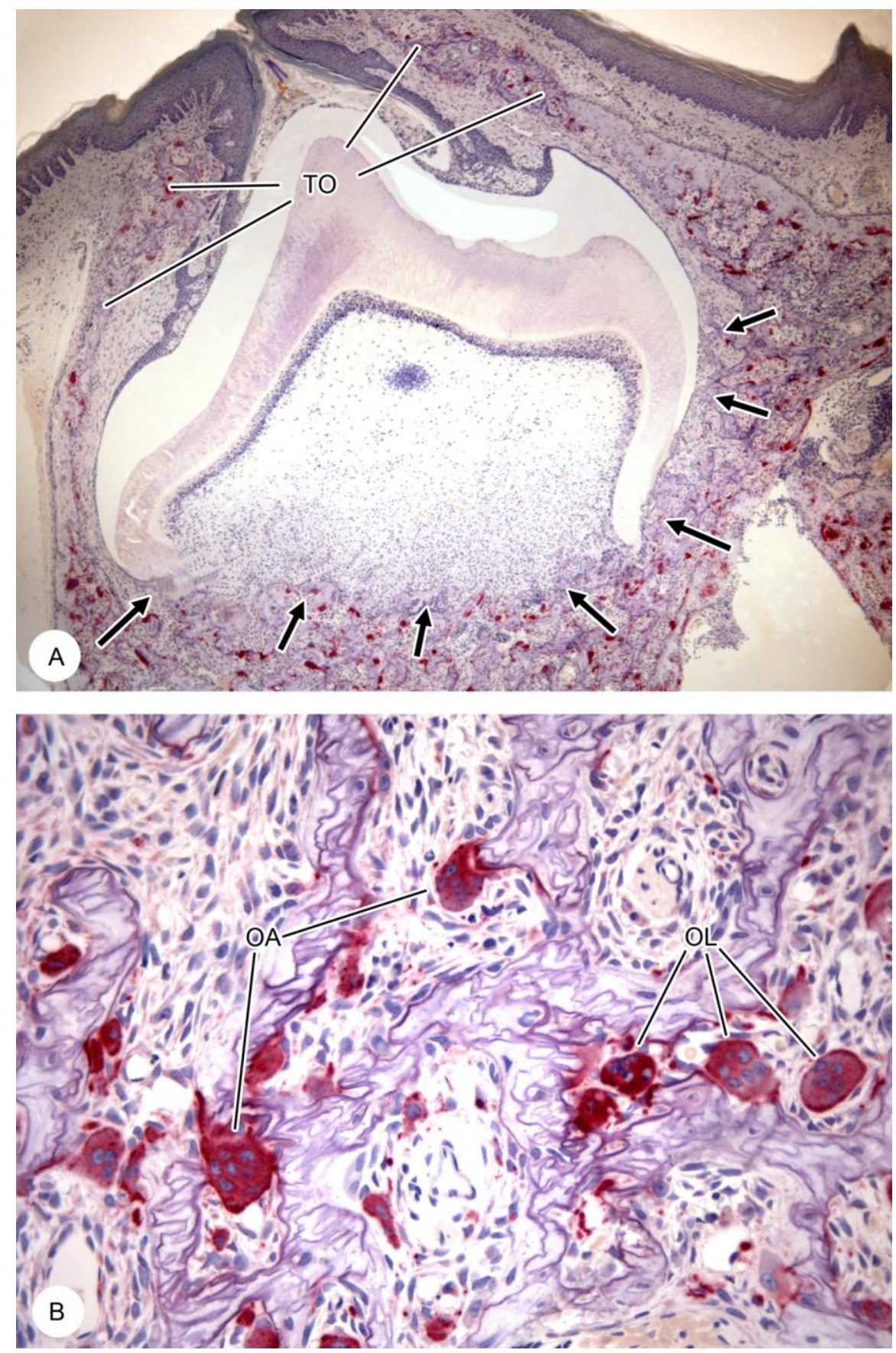

Em A, é ilustrado o germe do primeiro molar impactado no interior da cripta óssea. Observando o corte frontal, observa-se que há comunicação entre o epitélio reduzido do esmalte e o epitélio da mucosa oral. Entretanto, trabéculas ósseas permanecem recobrindo boa parte da porção oclusal do germe. Na porção cervical, observar diversos pontos de contato entre o germe dentário e trabéculas ósseas (setas). Osteoclastos TRAP positivos são observados em todas as regiões do osso alveolar. Em $B$, nota-se que há presença de osteoclastos latentes não aderidos $(\mathrm{OL})$ e alguns osteoclastos aderidos $(\mathrm{OA})$ às trabéculas. $A$, 20X, B, 200X 


\subsubsection{Grupo tratado com etidronato}

Aos quatro e oito dias de idade o folículo dentário e o osso alveolar ao redor dos primeiros molares dos animais tratados com etidronato apresentaram características normais. No espécime com oito dias, observaram-se áreas com aspecto atípico na superfície do esmalte. Os germes dentários estavam rodeados por osso alveolar da cripta, incluindo a região oclusal (Figura 17 A e B; Figura 18; Figura 19).

Aos catorze dias, foi observado que a formação de dentina radicular ocorria normalmente no primeiro molar (Figura 17 C; Figura 20). Foi observado que grande parte da porção oclusal da cripta óssea fora reabsorvida, dando origem à via eruptiva (Figura 17 D).

Aos vinte e oito dias, observou-se que parte da raiz fora formada, apresentando recobrimento de cemento celular, e que o molar erupcionara parcialmente (Figura 21). Foram observadas áreas de anquilose entre o osso alveolar e cemento (Figura 17 E e F). Foram observadas algumas células clásticas sobre a superfície da raiz em formação, e a presença de algumas pequenas lacunas de reabsorção (Fig. 21c). 
Figura 17 - Grupo tratado com etidronato. Tricrômico de Mallory.

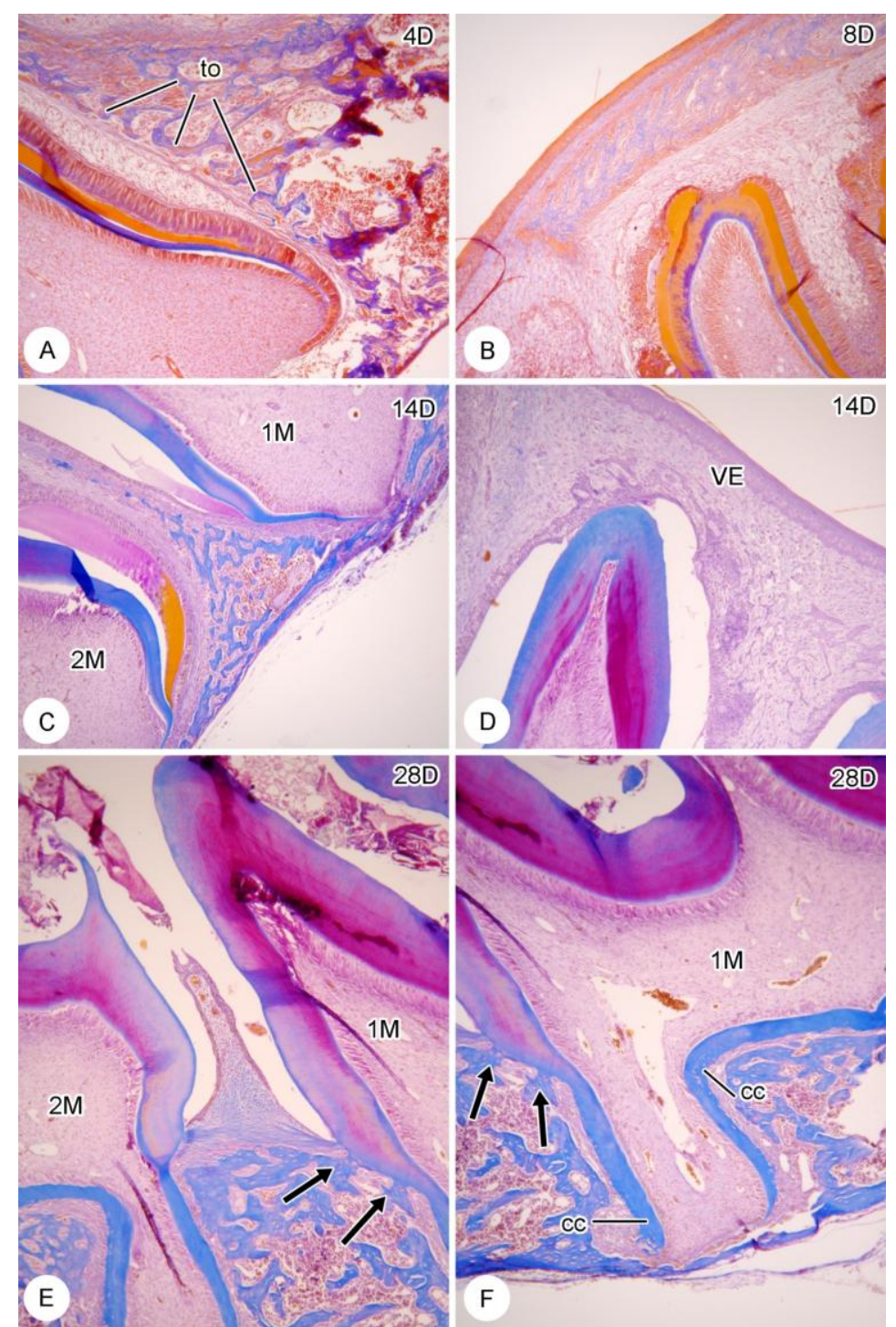

Em A, observa-se o primeiro molar superior (1M) de um espécime de 4 dias no interior da cripta, cercado por trabéculas ósseas (to). Notar a presença de algumas trabéculas ósseas que parecem atingir a região do folículo dentário. Em B, observam-se trabéculas ósseas na região oclusal da cripta, recobrindo o primeiro molar aos 8 dias de idade. Em C, aos 14 dias, observam-se as regiões basal e lateral da cripta, podendose notar o septo entre o primeiro (1M) e segundo molar (2M); nessa fase, uma parte da dentina radicular já foi formada. Em D, observa-se que na região oclusal a via eruptiva já foi formada, e o primeiro molar está sob a mucosa oral. A figura $E$ ilustra o primeiro e o segundo molar aos 28 dias. Algumas trabéculas ósseas do osso alveolar em formação estão em contato com o cemento radicular, caracterizando anquilose (setas). Nota-se que tanto o primeiro quanto o segundo molar se encontram parcialmente erupcionados. Em F, ainda se observam as mesmas áreas de anquilose na raiz distal do primeiro molar. Observa-se a presença de cemento celular (cc) recobrindo a raiz, incluindo a região da furca. A a $F, 40 X$. 
Figura 18 - Grupo tratado com etidronato, 4 dias. TRAP

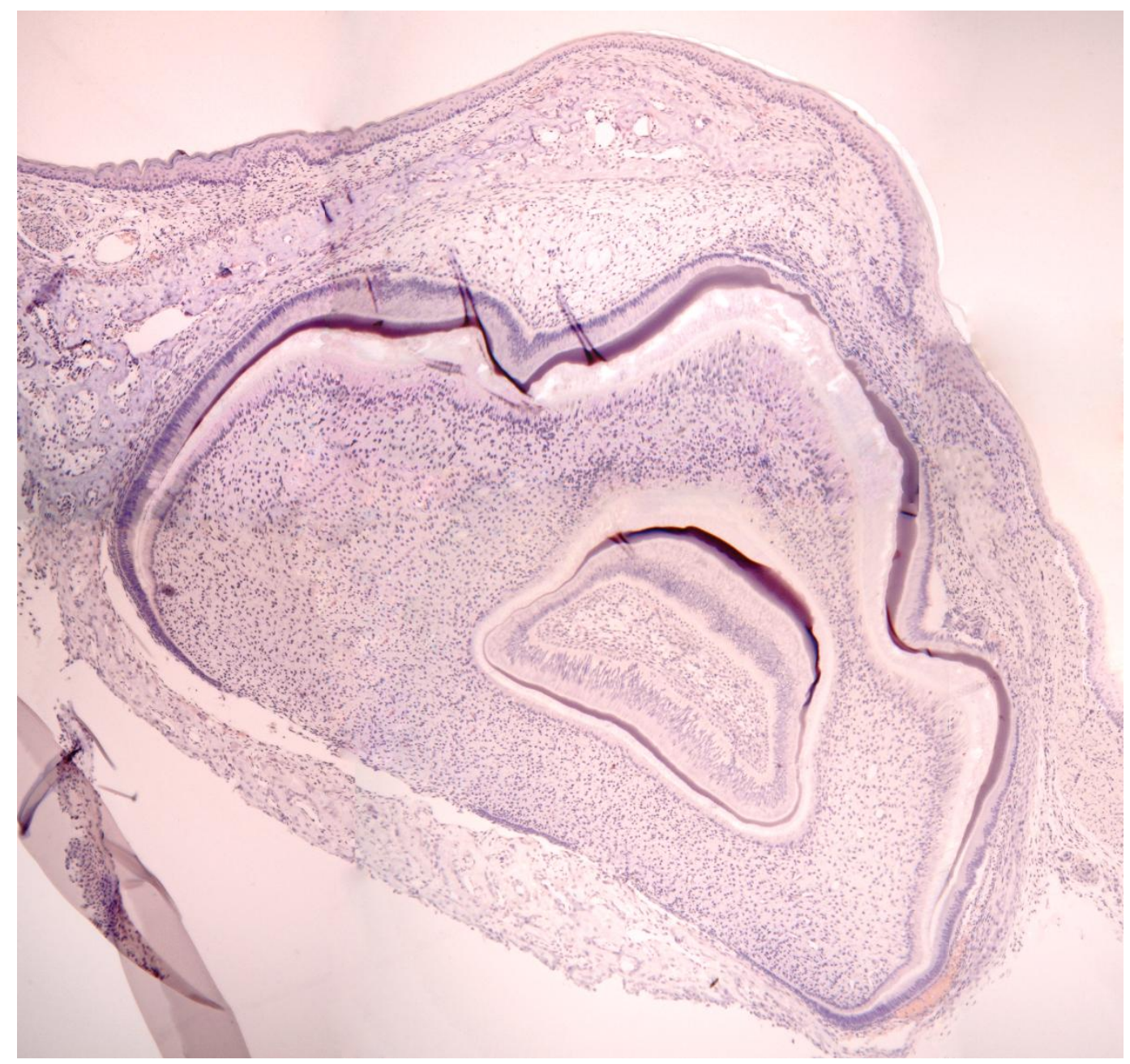

Germe dentário de espécime tratado com etidronato aos 4 dias de idade. Observa-se o germe, que neste momento encontra-se em fase de coroa, e a cripa óssea se formando ao seu redor. Nesta fase são raras as células TRAP-positivas observadas na cripta óssea. 20x. 
Figura 19 - Grupo tratado com etidronato, 8 dias. TRAP
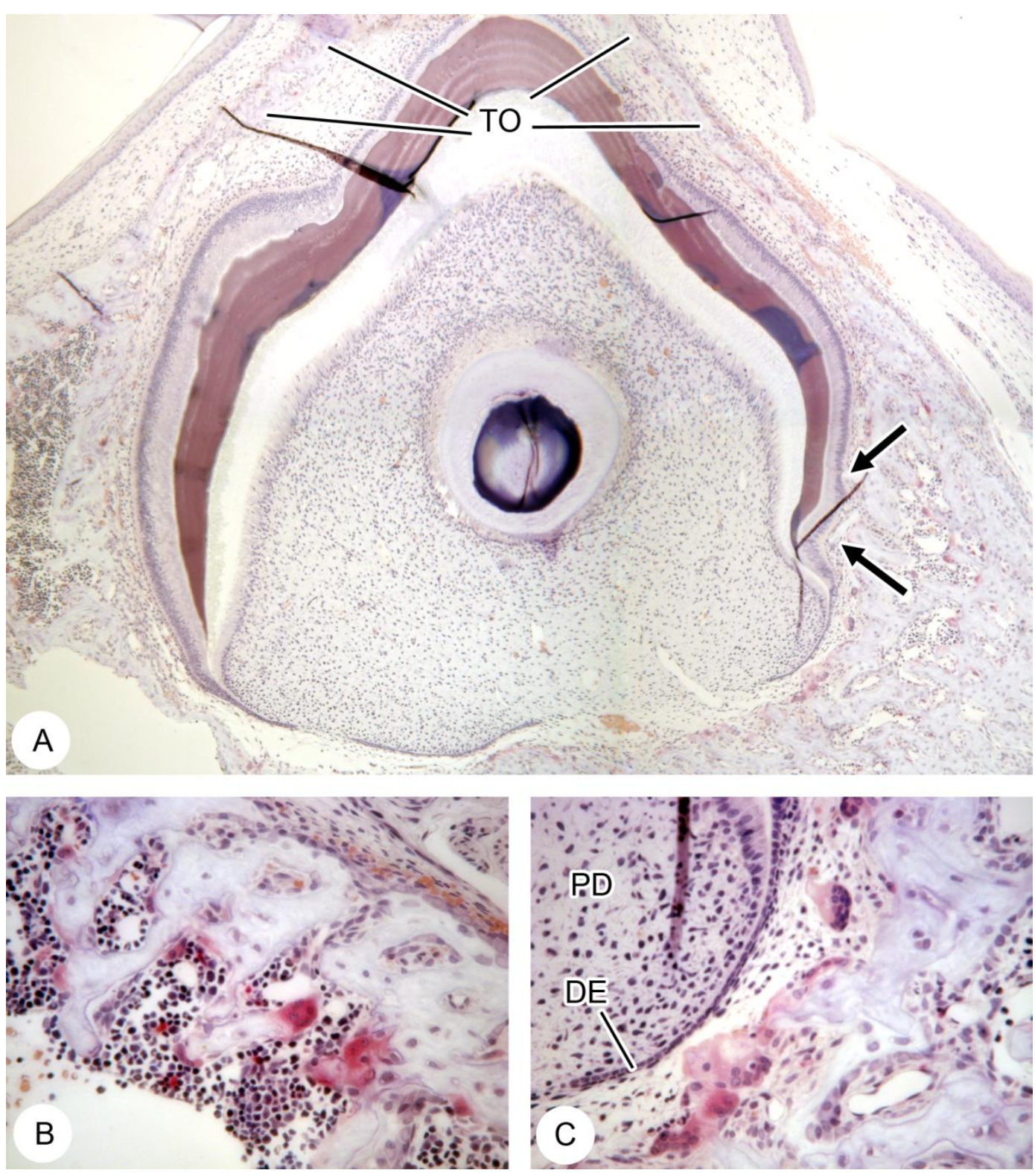

Em A, fotomicrografia ilustrando o germe do primeiro molar de um animal tratado com etidronato aos 8 dias de idade. Podem-se observar osteoclastos TRAP-positivos pelo osso da cripta (em vermelho). A superfície do esmalte apresenta irregularidades. Há trabéculas ósseas em contato com o germe dentário em alguns pontos (setas). Em B e C, osteoclastos TRAP positivos são observados nas regiões lateral e basal da cripta óssea, respectivamente. $\mathrm{PD}$, papila dentária; $\mathrm{DE}$, diafragma epitelial. A, 20X, B e C, 100X. 
Figura 20 - Grupo tratado com etidronato, 14 dias. TRAP.
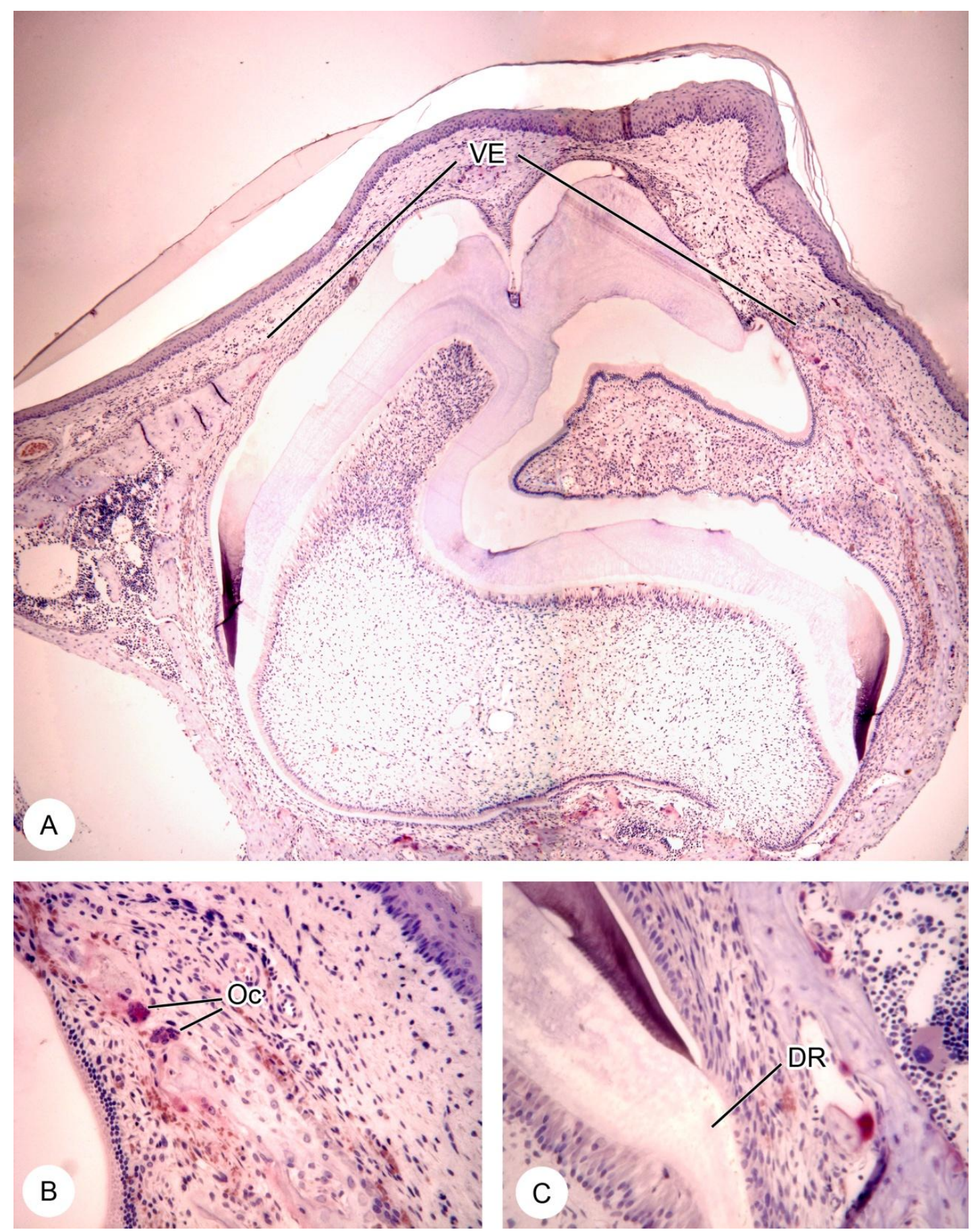

Em A, fotomicrografia ilustrando o germe do primeiro molar e o osso alveolar, onde se observa a via eruptiva (VE) sendo formada. Podem-se observar alguns osteoclastos TRAP positivos nas paredes e na base do alvéolo. Em B, são observados osteoclastos (Oc) TRAP-positivos na região da via eruptiva. Em $C$, é observada uma parte da dentina radicular (DR) sendo formada. A, 20X, B e C, 40X. 
Figura 21 - Grupo tratado com etidronato, 28 dias. TRAP.
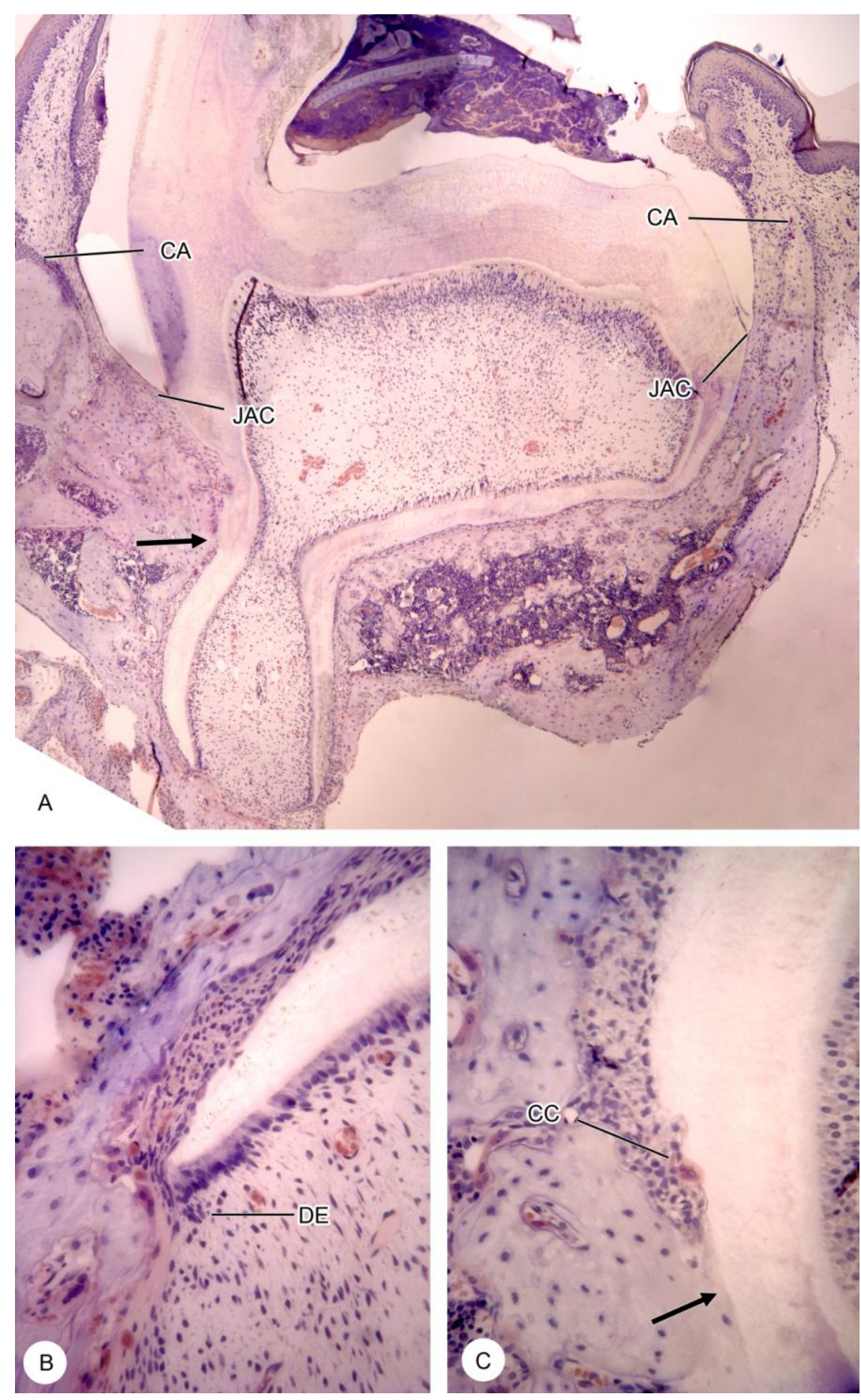

Em A, fotomicrografia ilustrando o primeiro molar parcialmente erupcionado. Notar queo nível da crista alveolar (CA) se encontra mais oclusal em relação ao nível da junção amelocementária (JAC). Observase um ponto de anquilose entre o osso alveolar e o cemento (seta). Em $\mathrm{B}$, é ilustrado o diafragma epitelial (DE) na porção apical da raiz em formação. Em C, uma célula clástica (CC) é vista próxima a uma lacuna de reabsorção na superfície radicular. Nota-se a presença de uma área de anquilose entre osso alveolar e cemento. (seta). A, 20X; B e C, 40X. 
Figura 22 - Histoquímica TRAP

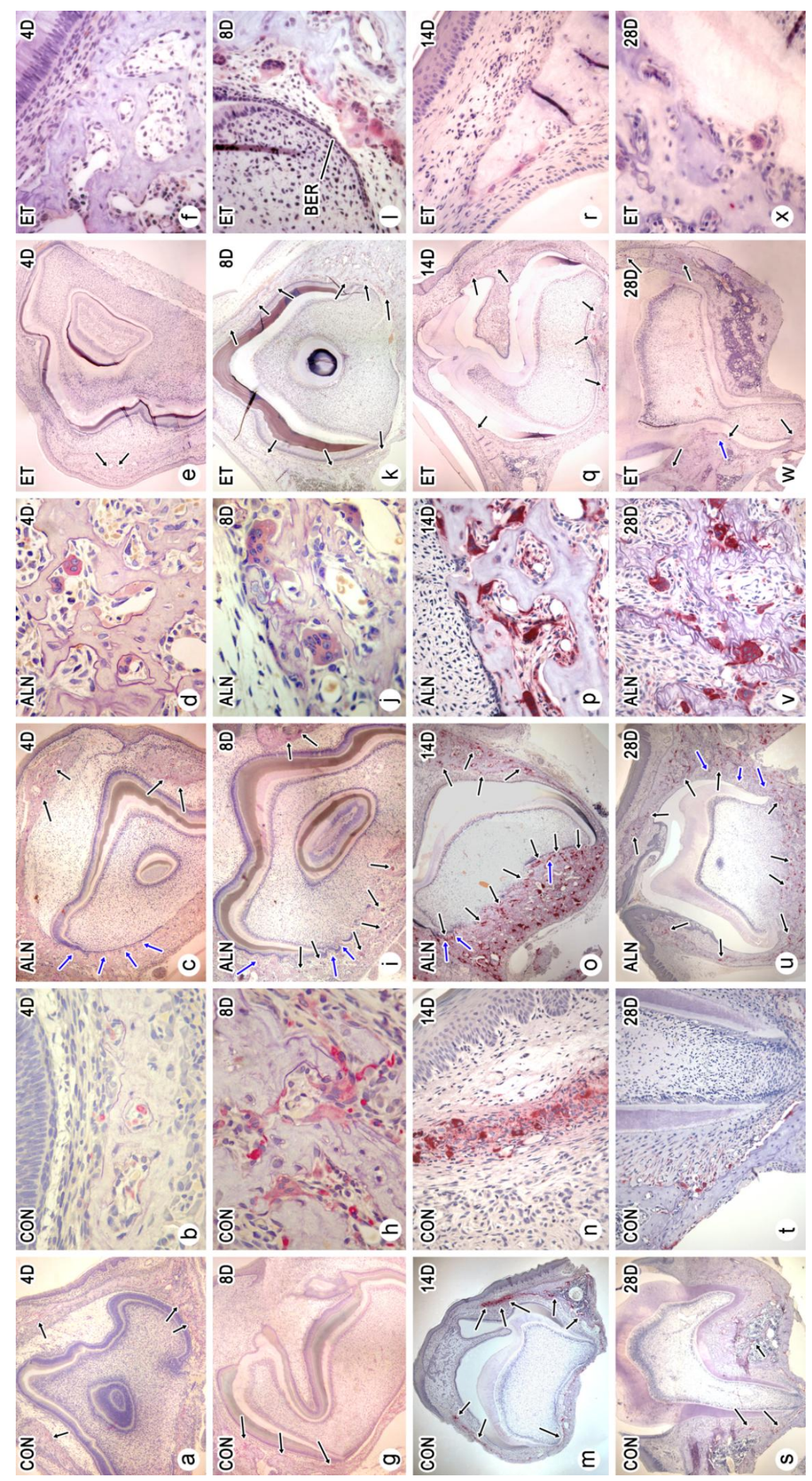


Na primeira linha, a e b ilustram espécimes controles, $\mathbf{c}$ e $\mathbf{d}$, espécimes tratados com alendronato, e e f, tratados com etidronato aos 4 dias de idade. Ao compararmos os grupos entre si, notamos que os três apresentam poucas células TRAP-positivas (setas) presentes no osso da cripta. As células presentes foram detectadas principalmente nas regiões oclusal e basal da cripta. Neste período, o espécime tratado com alendronato apresenta contato de trabéculas ósseas em alguns pontos do germe dentário (setas azuis). Na segunda linha, $\mathbf{g}$ e $\mathbf{h}$ ilustram espécimes controles, i e j ilustram espécimes tratados com alendronato e $\mathbf{k}$ e $\mathbf{~}$, tratados com etidronato aos 8 dias de idade. Os controles apresentaram numerosos osteoclastos nas regiões lateral e basal da cripta, e na região oclusal pode ser observada a via eruptiva sendo estabelecida. Ao observarmos em maior aumento, os osteoclastos parecem ativados e aderidos às trabéculas ósseas. Nos animais tratados com alendronato são observados numerosos osteoclastos TRAP positivos em todas as regiões da cripta. Observa-se a presença de trabeculado ósseo recobrindo o germe do primeiro molar. Em maior aumento, os osteoclastos parecem inativados apesar de multinucleados e próximos às trabéculas ósseas. Nos espécimes tratados com etidronato, em k, observa-se a formação da via eruptiva como no controle. Observam-se numerosos osteoclastos na base da cripa, na região próxima à bainha epitelial radicular (BER) em proliferação apical. Os osteoclastos apresentam-se distantes das trabébulas ósseas, havendo alguns aderidos às mesmas. Na terceira linha, $\mathbf{m}$ e $\mathbf{n}$ ilustram espécimes controles aos 14 dias de idade, o e p ilustram espécimes tratados com alendronato e $\mathbf{q}$ e $\mathbf{r}$, espécimes tratados com etidronato. Nesta fase, os controles apresentam muitos osteoclastos na região ocluso-lateral, na qual há poucas trabéculas ósseas. Neste período, portanto, a via eruptiva está quase totalmente estabelecida. A base da cripta também apresenta alguns osteoclastos, que participam da remodelação óssea que ocorre na região durante a formação do periodonto. Os espécimes tratados com alendronato apresentam muitos osteoclastos em toda a cripta óssea; não há formação de via eruptiva. Os osteoclastos, analisados em maior aumento em $\mathbf{p}$, apararentam estar inativos. Os espécimes tratados com etidronato, por sua vez, apresentam grande parte da porção oclusal da cripta reabsorvida; entretanto, menos células TRAP positivas são visualizadas em comparação com os controles e tratados com alendronato. $\mathrm{Na}$ quarta linha, $\mathbf{s}$ e $\mathbf{t}$ ilustram espécimes controles, $\mathbf{u}$ e $\mathbf{v}$ ilustram espécimes tratados com alendronato e $\mathbf{w}$ e $\mathbf{x}$ aos 28 dias. Os controles apresentam parte da coroa erupcionada. Observa-se que o limite amelocementário do primeiro molar se encontra em nível mais oclusal, à altura da crista alveolar. Nesta fase, osteoclastos são encontrados no osso alveolar próximo ao ápice radicular e na região do septo alveolar. Nos animais tratados com alendonato, observa-se ausência de formação radicular e de erupção da coroa. Há muitos osteoclastos aparentemente inativados no osso da cripta ao redor do germe não erupcionado. Nos espécimes tratados com etidronato, observa-se que parte da coroa erupcionou. Entretanto, pode-se notar que o limite amelocementário do primeiro molar neste grupo permanece aquém da crista alveolar, caracterizando que o processo eruptivo neste grupo está atrasado comparado ao controle. São observadas áreas de anquilose em alguns pontos da raiz em formação, e também algumas lacunas de reabsorção na superfície radicular. Em x, observa-se uma célula clástica TRAP-positiva próxima a uma lacuna de reabsurção na raiz. Aumentos originais: a, c, e, g, i, k, m, o, q, s, u, w: 10x. b, d, f, h, j, I, x: 100X; n, p, r, t, v: 40X. 
5.1.4 Análise das células TRAP positivas

Analisando as células TRAP positivas na região oclusal da cripta óssea, observou-se que o grupo tratado com alendronato sódico apresentou maior número de células em todos os períodos estudados em relação aos tratados com etidronato e controles (Gráfico 1). A maioria das células contadas em todos os grupos apresentou de 1 a 4 núcleos, sendo mais numerosas as células contendo 2 a 4 núcleos (Gráfico 2).

Quanto à ativação das células TRAP positivas, o grupo tratado com alendronato apresentou menor proporção de células ativadas em todos os períodos analisados. Os grupos tratados com etidronato e controle apresentaram maior quantidade de células ativas aos 4 dias de idade; entretanto, esta diferença diminuiu aos 14 dias, quando o número de células ativadas e latentes foi semelhante. Nos controles, o número de células ativadas foi superior aos 4 e 14 dias. Aos 28 dias, apenas o grupo tratado com alendronato apresentou células TRAP positivas na região analisada devido à ausência de formação de via eruptiva. Nos demais grupos, esta porção da cripta óssea fora reabsorvida (Gráfico 3). 
Gráfico 1: Análise do número de células TRAP positivas na superfície óssea oclusal da cripta nos grupos controle e tratados com alendronato e etidronato.

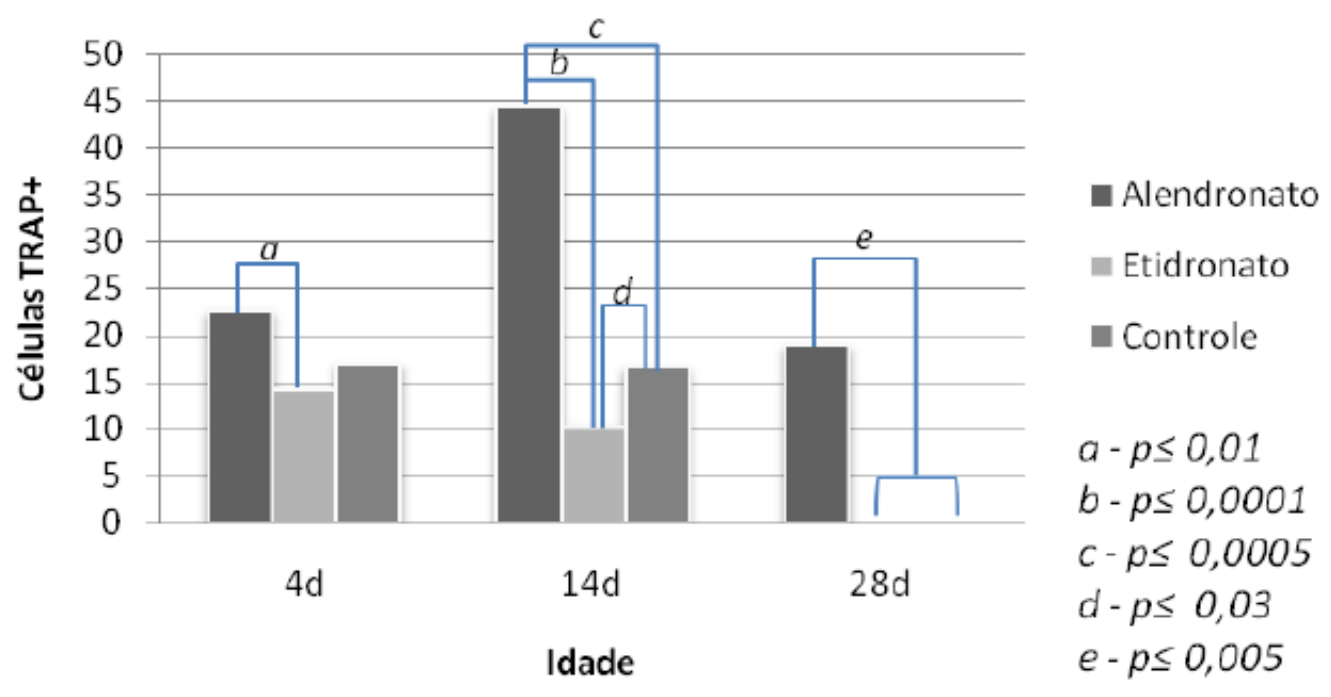

Foram contadas as células TRAP positivas presentes na região oclusal da cripta óssea. Aos 4 dias, o grupo tratado com alendronato apresentou maior número de células TRAP positivas que os demais grupos, sendo esta diferença significativa entre os grupos alendronato e etidronato. Aos 14 dias, o número de células TRAP positivas no grupo tratado com alendronato foi significantemente maior que nos demais grupos. $O$ grupo tratado com etidronato apresnetou menos células que o grupo controle.

Aos 28 dias, somente o grupo tratado com alendronato apresentou células TRAP positivas, pois nos demais grupos a região oclusal da cripta óssea fora reabsorvida. 
Gráfico 2 - Classificação das células TRAP positivas de acordo com o número de núcleos.

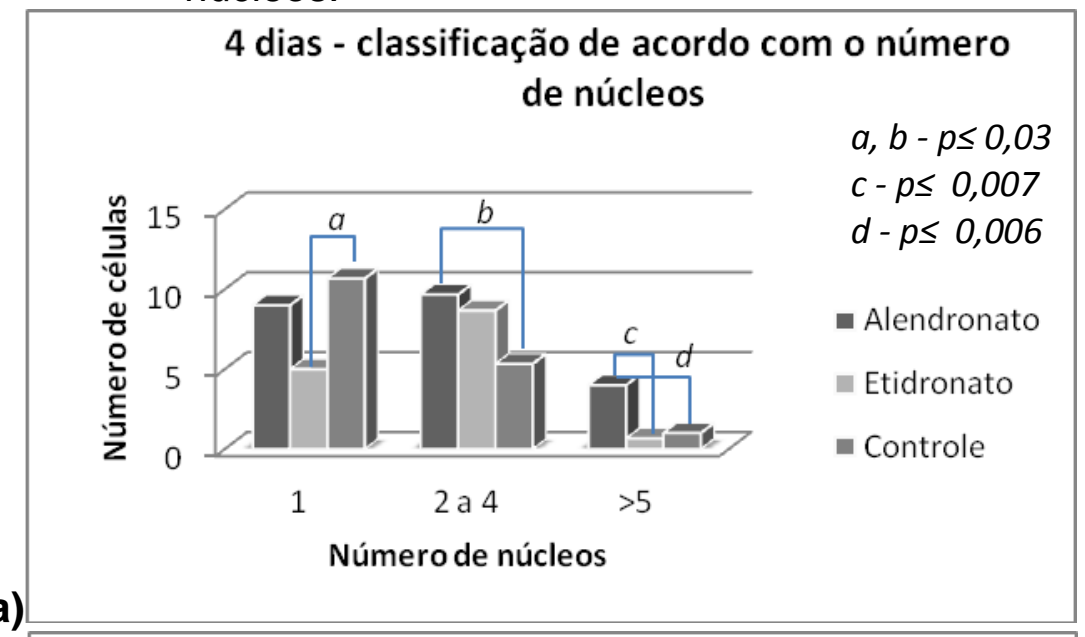

a)

b)

14 dias - classificação de acordo com o número de núcleos

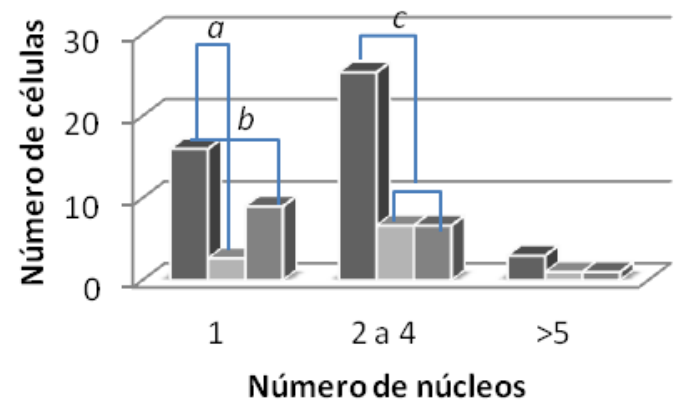

$a-p \leq 0,0001$

$b-p \leq 0,05$

$c-p \leq 0,007$

- Alendronato

= Etidronato

- Controle

28 dias - classificação de acordo com o número de núcleos

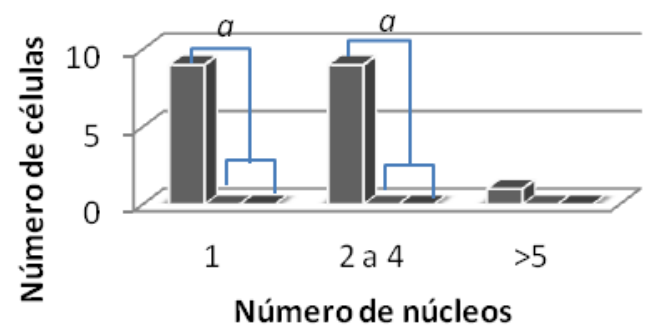

$a-p \leq 0,0001$

- Alendronato

- Etidronato

- Controle

c)

Em a, aos 4 dias, número de células mononucleares no grupo controle foi significativamente maior que o do grupo etidronato. $\mathrm{O}$ grupo alendronato apresentou maior número de células com 2 a 4 núcleos (miltinucleadas) e com mais de 5 núcleos (gigantes). Em b, aos 14 dias, o grupo alendronato apresentou maior número de células TRAP positivas mono e multinucleadas em relação aos demais grupos. Em c, aos 28 dias, somente o grupo alendronato apresnettou células TRAP-positivas na porção oclusal da cripta, pois nos demais grupos houve formação de via eruptiva 
Gráfico 3 - Análise do número de células TRAP positivas ativadas.

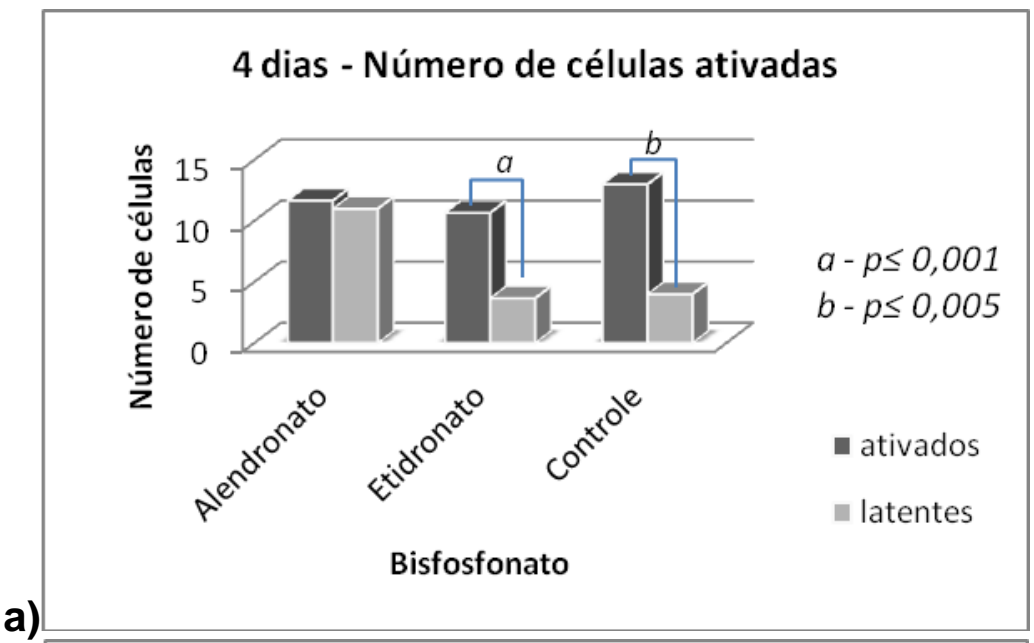

a)

b)

14 dias - Número de células ativadas
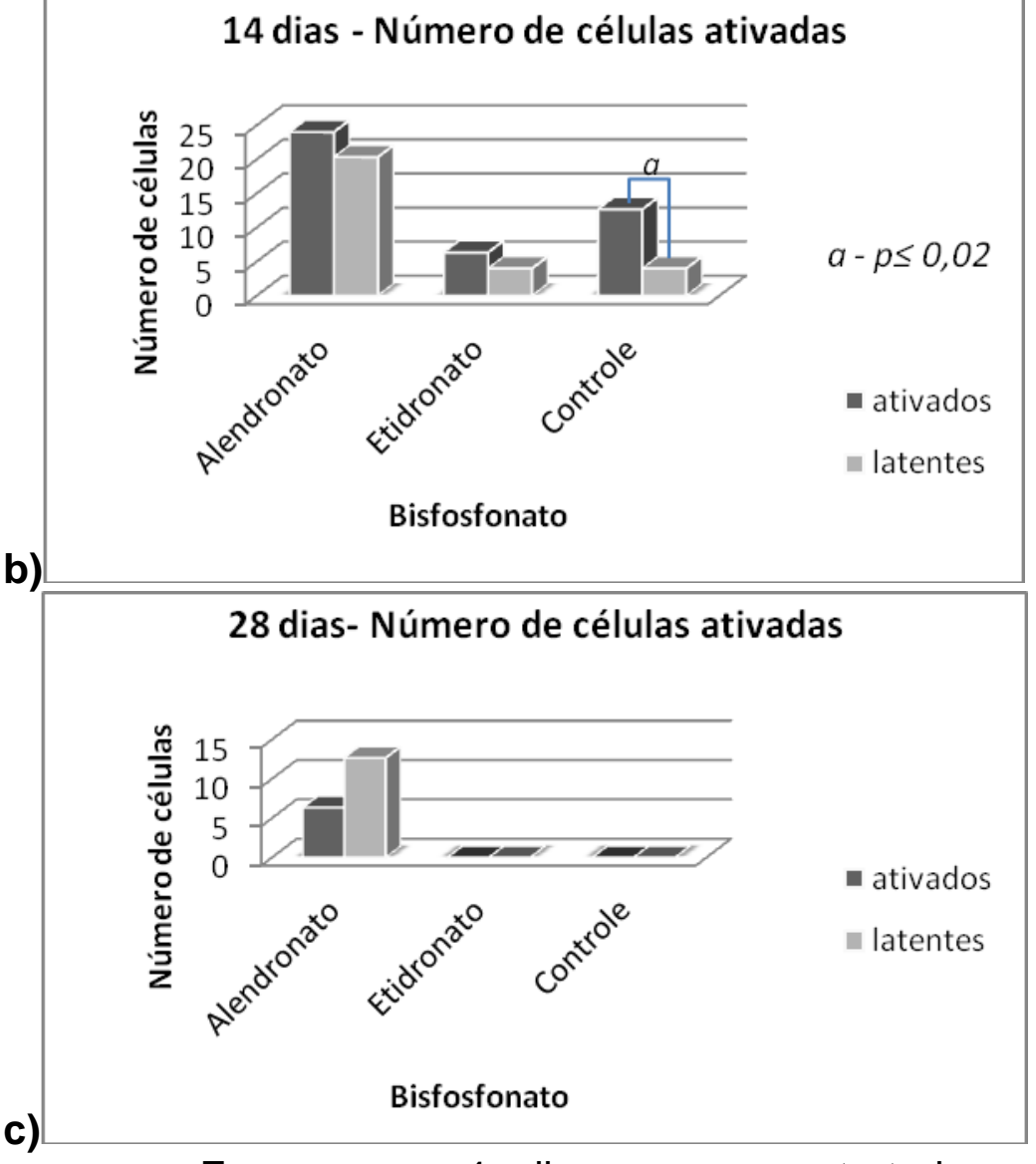

Em a, aos 4 dias, o grupo tratado com alendronato apresentou aproximadamente a mesma quantidade de células TRAP positivas ativadas e latentes. Nos grupos tratados com etidronato e controle, o número de células ativadas foi maior que o de células latentes. $\mathrm{Em} \mathrm{b}$, aos 14 dias, o grupo tratado com alendronato não apresentou diferença entre a quantidade de células ativadas e latentes; o mesmo ocorreu para o grupo tratado com etidronato. No grupo controle, o número de células ativadas foi superior ao de células latentes. Em c, somente o grupo tratado com alendronato apresentou células TRAP positivas, e não houve diferença significativa entre o número de células ativadas e latentes. 


\subsection{Aspectos ultra-estruturais}

As mandíbulas dos animais tratados com alendronato, etidronato e controles foram desproteinizadas e processadas para análise em microscopia eletrônica de varredura com a finalidade de melhor ilustrar o processo de erupção dentária.

Os espécimes tratados com alendronato apresentaram, aos catorze dias, a superfície do esmalte da coroa deformada em alguns pontos, enquanto os controles apresentaram o esmalte com aspecto liso e homogêneo. Na região cervical, parte da matriz do esmalte jovem fora removida por conter alta concentração de conteúdo orgânico. Aos trinta dias, foi constatada a erupção do primeiro molar e do incisivo nos espécimes controles, o que não ocorreu nos tratados com alendronato. $O$ primeiro molar permaneceu recoberto por trabéculas ósseas, sendo observada uma fenda longitudinalmente sobre a face oclusal do germe dentário. Apenas uma pequena parte do incisivo erupcionou. Analisando-se os molares removidos da base óssea, observou-se uma grande parte da raiz formada no primeiro molar do grupo controle, enquanto o grupo tratado não apresentou dentina radicular. $O$ esmalte da coroa apresentou-se rugoso aparentemente em toda sua superfície (Figura 23).

Os espécimes tratados com etidronato apresentaram, aos 14 dias, algumas regiões da superfície do esmalte com aspecto hipoplásico, e algumas rugosidades. Aos 28 dias, a superfície radicular apresentou aspecto irregular, ao contrário da raiz do primeiro molar do controle, que por sua vez apresentou superfície com aspecto mais liso. A coroa do primeiro molar dos espécimes tratados com etidronato estava parcialmente erupcionada, estando o terço cervical aparentemente recoberto por tecido ósseo (Figuira 24). 
Figura 23 - Grupo tratado com alendronato e controle. MEV.
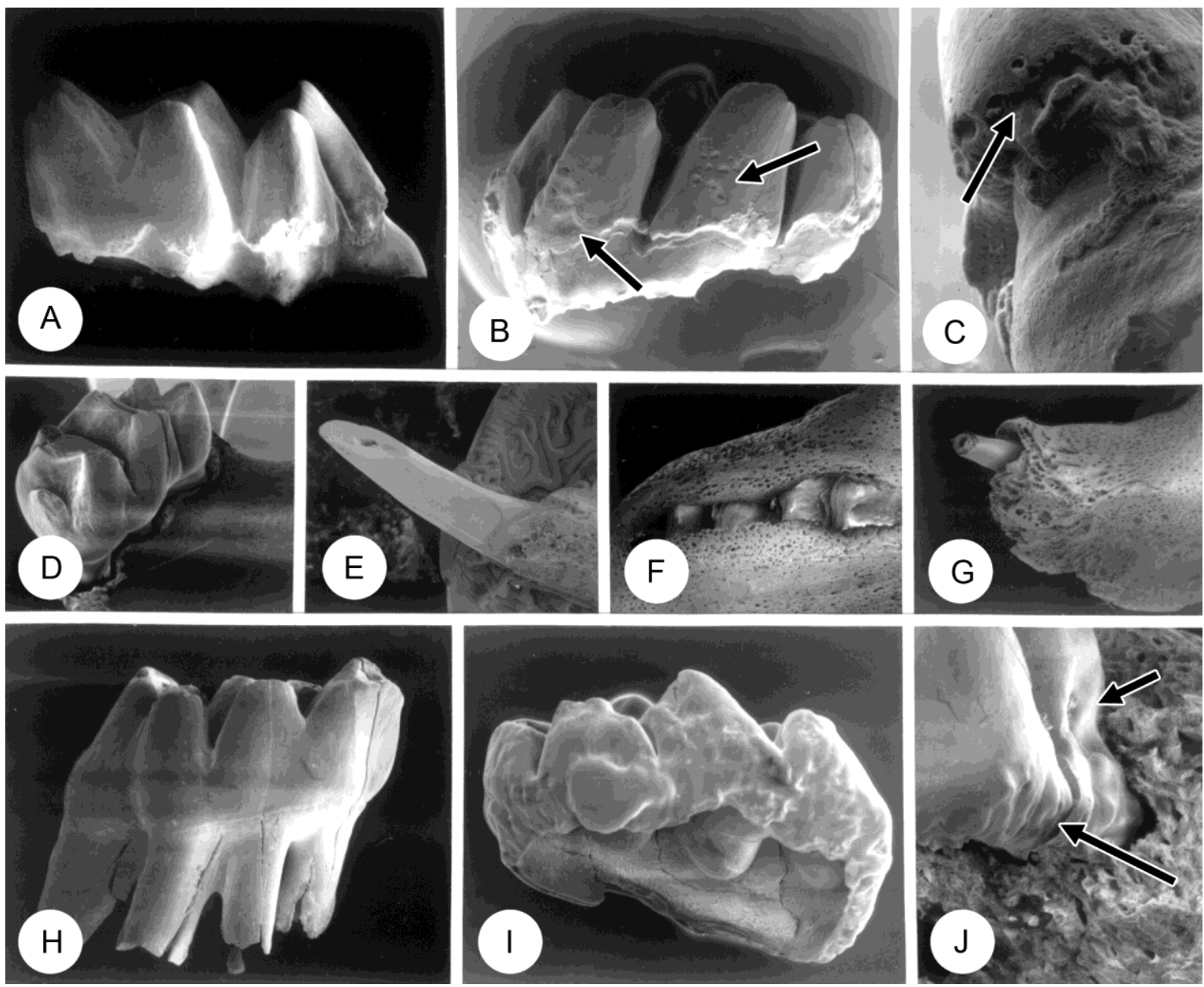

Aos 14 dias, em A, é ilustrada a coroa do primeiro molar inferior do grupo controle. Observar o aspectoi liso da superfície do esmalte em comparação com a coroa do animal tratado com alendronato, que apresentou deformidades (setas). Em C, uma depressão no esmalte da região cervical é apontada (seta). Aos 30 dias, observam-se a coroa do primeiro molar (em D) e o incisivo (em E) erupcionados. Nos animais tratados, a erupção do molar não ocorreu (em F) e apenas uma curta porção do incisivo erupcionou (em G). Em $\mathrm{H}$, observa-se o primeiro molar do controle com grande parte da raiz formada. Em I, a coroa do primeiro molar do espécime tratado não apresentou formação radicular. Em J, observa-se o primeiro molar impactado no osso alveolar, com deformidades na superfície (setas). A, 90X; B e I, 100X; C, 550X; D, E e G, 60X; F, 45X; H, 80X; J, 200X. 
Figura 24 - Grupo tratado com etidronato e controle. MEV.
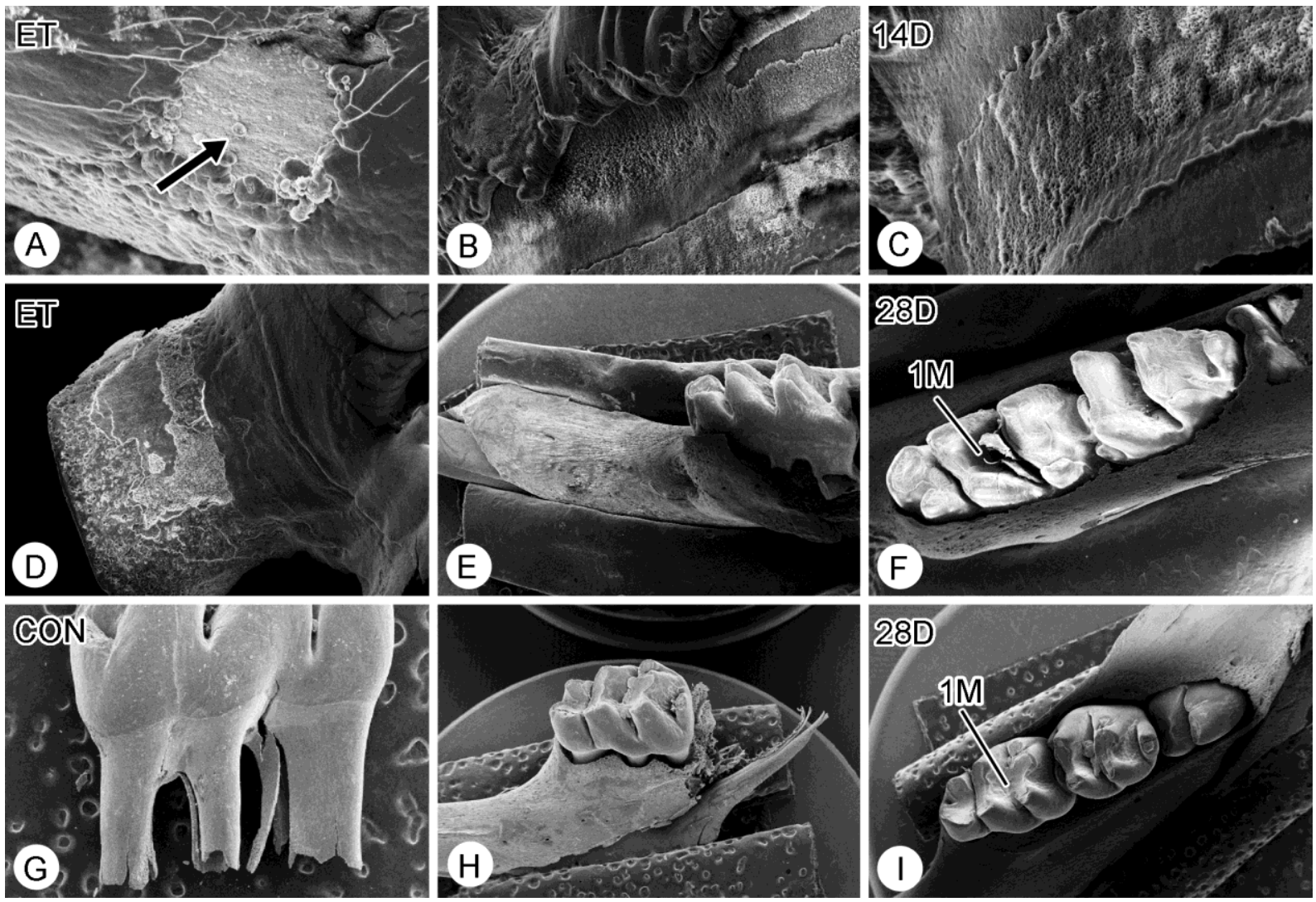

Em A, é mostrada uma área aparentemente hipoplásica no esmalte da coroa do primeiro molar (seta) aos 14 dias. Em B e C, observa-se a região cervical do germe dentário. $\mathrm{Em} \mathrm{D}$, aos 28 dias, observa-se parte do primeiro molar, cuja raiz apresenta recobrimento com cemento com aspecto irregular. Em E e F, nota-se que a coroa do primeiro molar (1M) apresenta-se parcialmente erupcionada. Em G, é mostrado o primeiro molar do controle, cuja raiz apresenta superfície lisa e regular. $\mathrm{Em} \mathrm{H} \mathrm{e} \mathrm{I,}$ nota-se que a coroa do primeiro molar fora completamente erupcionada. A a C 500X; D, 100X; E, He I, 45X; F, 60X, G, 80X. 
Ao serem analisados em microscopia eletrônica de transmissão, foram revelados detalhes ultra-estruturais do germe dentário, do tecido ósseo e dos osteoclastos dos diferentes grupos.

Nos animais tratados com alendronato, aos quatro dias de idade, foram observadas trabéculas ósseas entre pré-ameloblastos na região cervical do germe dentário. Foi também observada fragmentação de pequenas áreas da lâmina basal, e algumas fibrilas colágenas, provavelmente oriundas da matriz de dentina do manto, entre os pré-ameloblastos (Figura 25). Aos catorze dias, foi observado nos espécimes tratados com alendronato o contato de trabéculas ósseas com o folículo dentário e células do órgão do esmalte. No osso alveolar da cripta, foram observados osteoclastos multinucleados, arredondados e parcialmente aderidos à matriz óssea por estreitos podossomos (Figura 26). Aos 28 dias, observou-se na região cervical da coroa do primeiro molar o contato de trabéculas ósseas com o esmalte em maturação. Osteoclastos latentes, não aderidos à matriz óssea foram encontrados nos espaços entre as trabéculas ósseas (Figura 27).

Os espécimes tratados com etidronato, aos quatro dias, apresentaram osteoblastos contendo acúmulos de material granular elétron-opaco no citoplasma (Figura 28). Aos catorze e vinte e oito dias, foi observada sobre as trabéculas ósseas uma espessa camada de osteóide, o qual continha alguns osteócitososteoides. Foram observados também osteoclastos multinucleados próximos a trabéculas ósseas, porém sem o aparato de adesão e reabsorção, isto é, zona de adesão e borda em escova (Figuras 29 e 30 ).

Analisando comparativamente os osteoclastos dos três grupos, alendronato, etidronato e controle, foi observado que, nos espécimes controles, os osteoclastos se encontraram ativados e aderidos à superfície de trabéculas ósseas. Estes apresentaram típico aparato de adesão à matriz mineralizada, constituído por zona clara e borda em escova, e numerosos vacúolos no citoplasma. Nos espécimes tratados com alendronato notou-se que, diferentemente dos controles, os osteoclastos estavam aderidos às superfícies ósseas através de curtos podosomos. Observou-se, em alguns osteoclastos, algumas áreas de contato mais extensas com a matriz óssea, porém não foi notada presença de zona clara. Nestes osteoclastos, 
não se pode afirmar que foi formada zona de selamento típica. Nos espécimes tratados com etidronato, os osteoclastos se apresentaram ativados, aderidos à matriz óssea, com zona clara e borda em escova. Alguns osteoclastos estavam aderidos à matriz óssea, porém através de podossomos estreitos, e também apresentando aspecto apoptótico ou autofágico (Figura 31). 
Figura 25 - Grupo tratado com alendronato, 4 dias. MET.
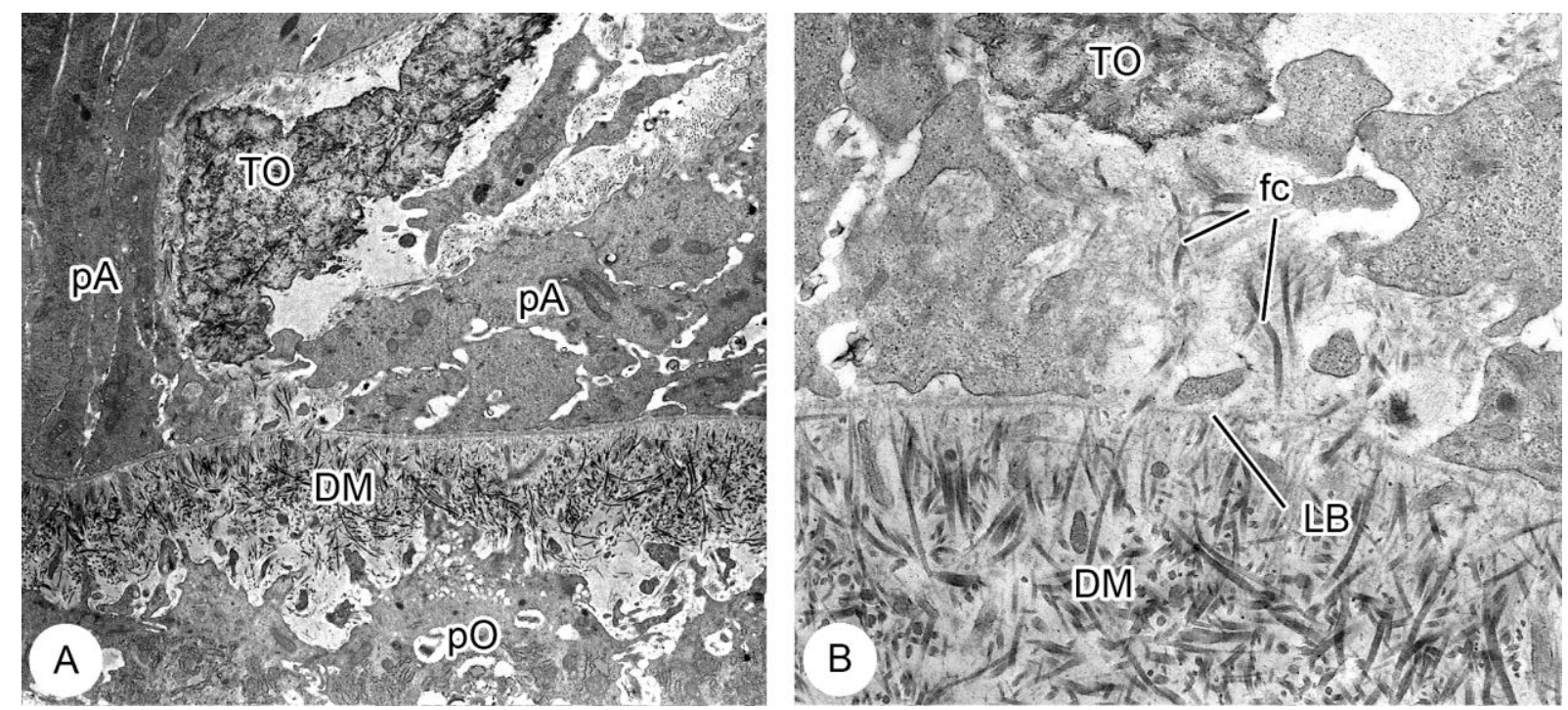

Micrografia eletrônica de transmissão ilustrando a região cervical do germe dentário. Foi observada presença de espículas ósseas (to) entre pré-ameloblastos $(\mathrm{pA})$ durante as fases iniciais da dentinogênese, ocasionando inclusive fragmentação da lâmina basal (LB). DM, dentina do manto; pO, pré-odontoblasto, fc, fibrilas colágenas. A, 3700X; B, 9300X. 
Figura 26 - Grupo tratado com alendronato, 14 dias. MET.
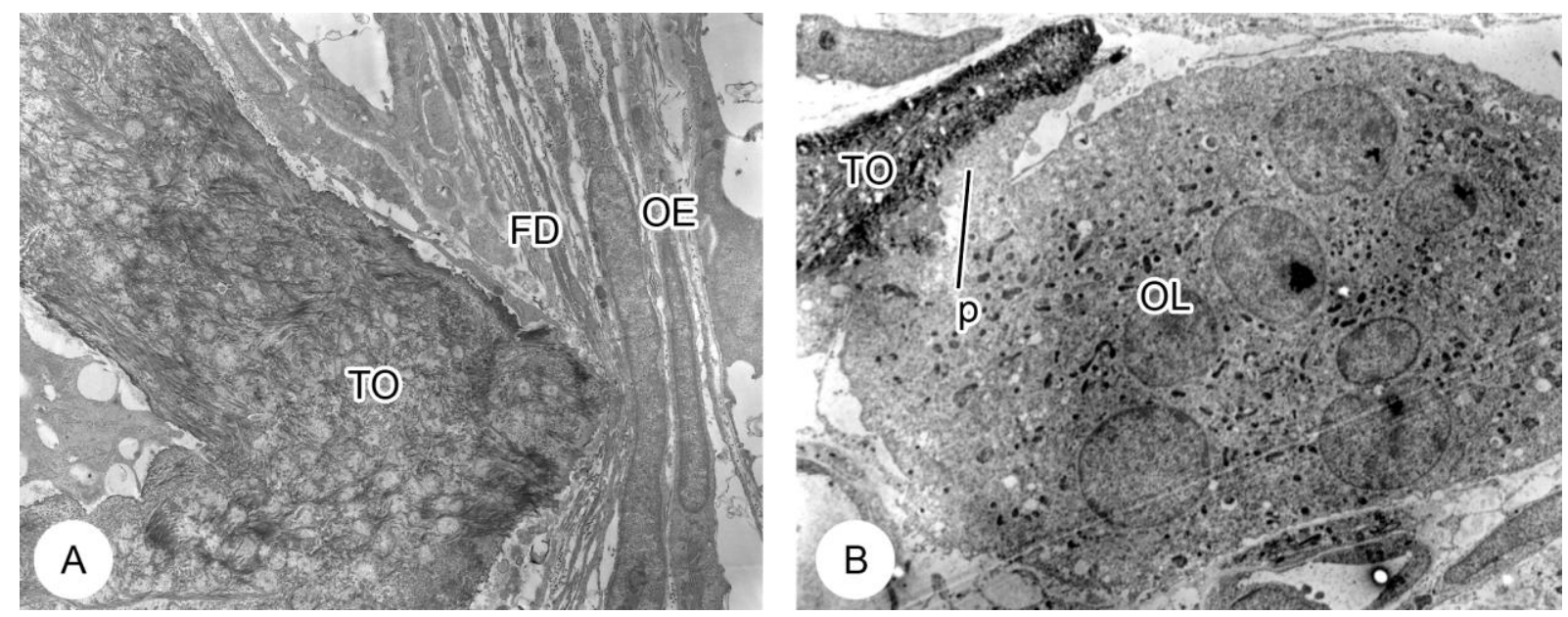

Em A, é ilustrado o de uma trabécula óssea (TO) com o folículo dentário (FD) e o órgão do esmalte. Em B, um osteoclasto latente (OL) sem sinais de atividade reabsortiva é observado aderido a uma trabécula óssea por um estreito podossomo (p). A, 4000X; B, 3000X. 
Figura 27 - Grupo tratado com alendronato, 28 dias. MET.
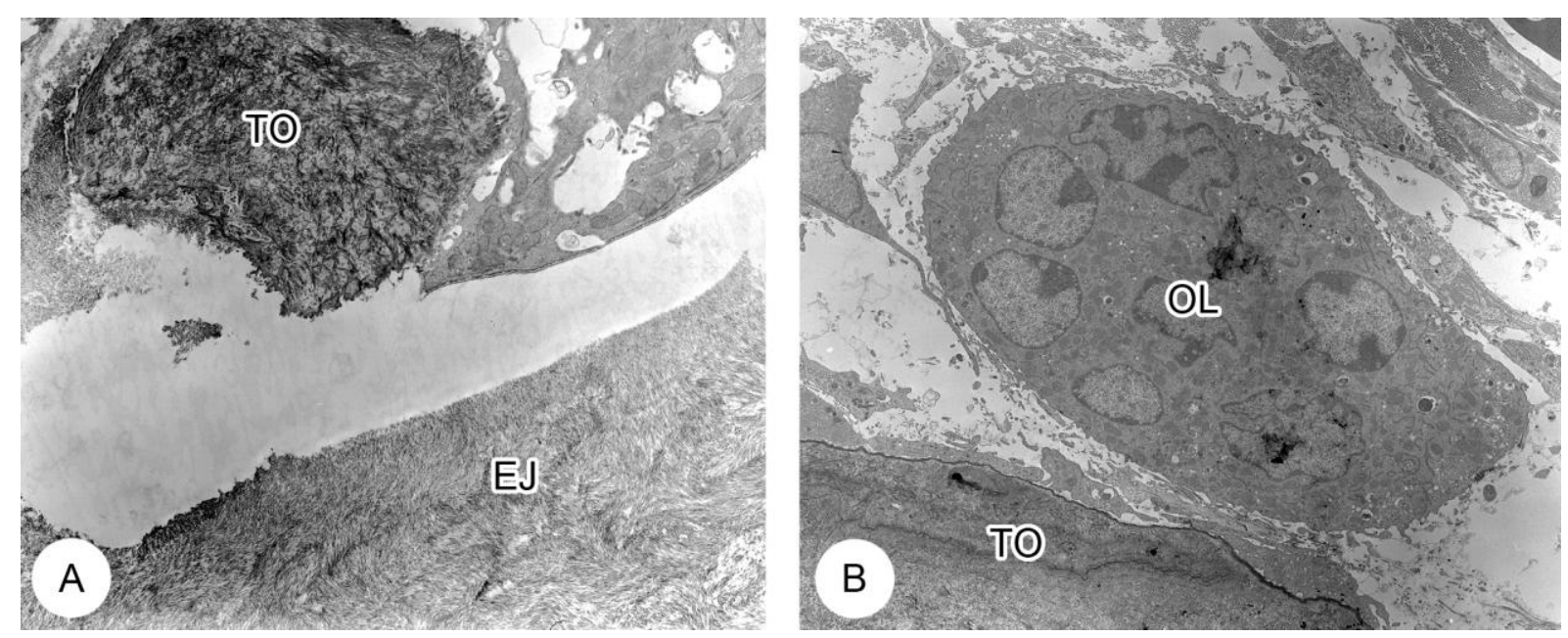

Em A, é mostrada uma trabécula óssea (TO) próxima ao esmalte jovem (EJ) na região cervical da coroa. O espaço entre as duas estruturas é aparentemente um artefato. Em B, um osteoclasto latente $(\mathrm{OL})$ é observado próximo a uma trabécula óssea. A, 3400X; B, 2300X. 
Figura 28 - Grupo tratado com etidronato, 4 dias. MET.
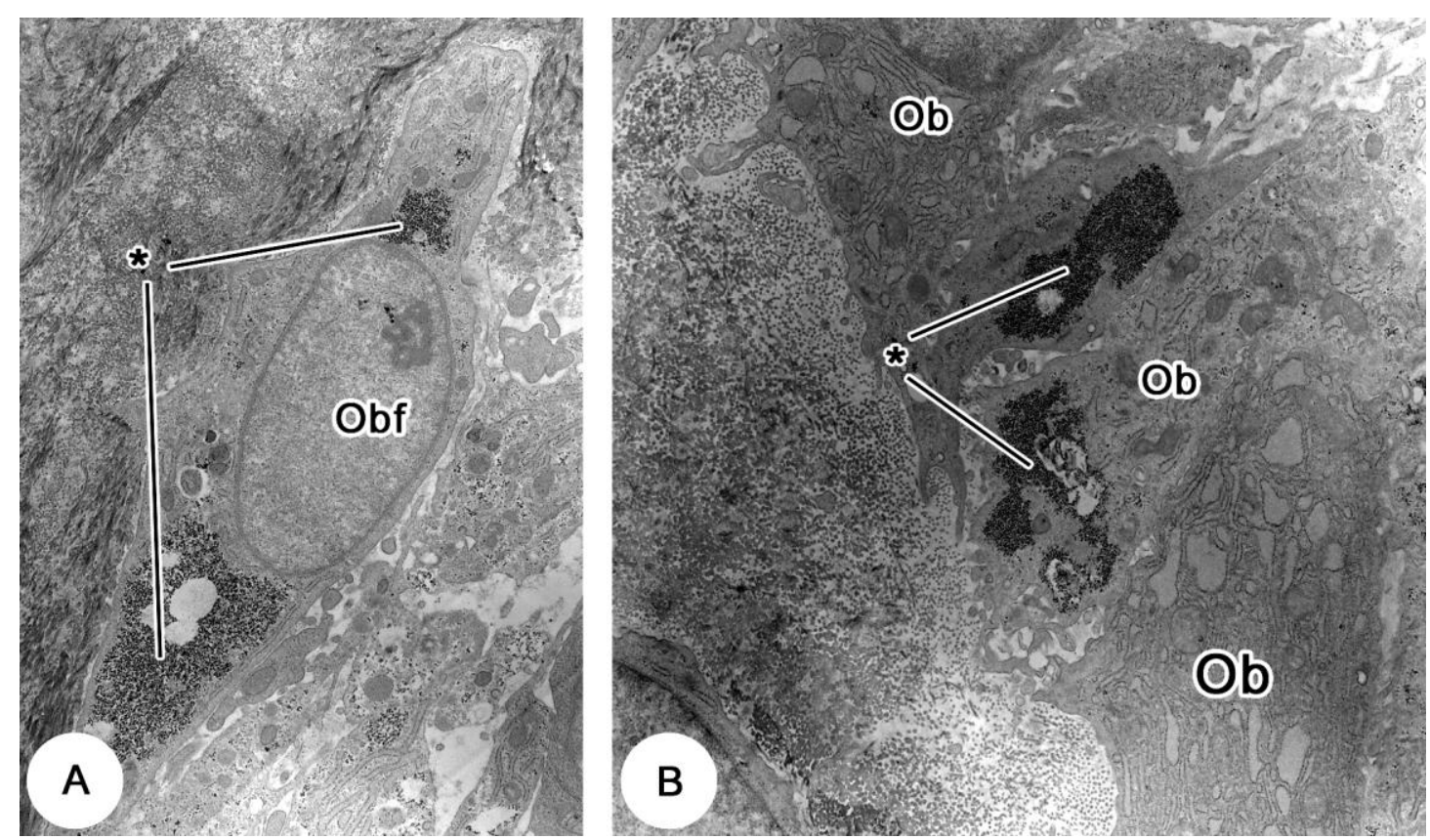

Micrografias eletrônicas de transmissão ilustrando, em $A$, uma célula de revestimento ósseo fusiforme (Obf) e, em $\mathrm{B}$, osteoblastos (Ob) apresentando material granular eletron-opaco (asterisco) acumulado no citoplasma. A e B, 5000X. 
Figura 29 - Grupo tratado com etidronato, 14 dias. MET.
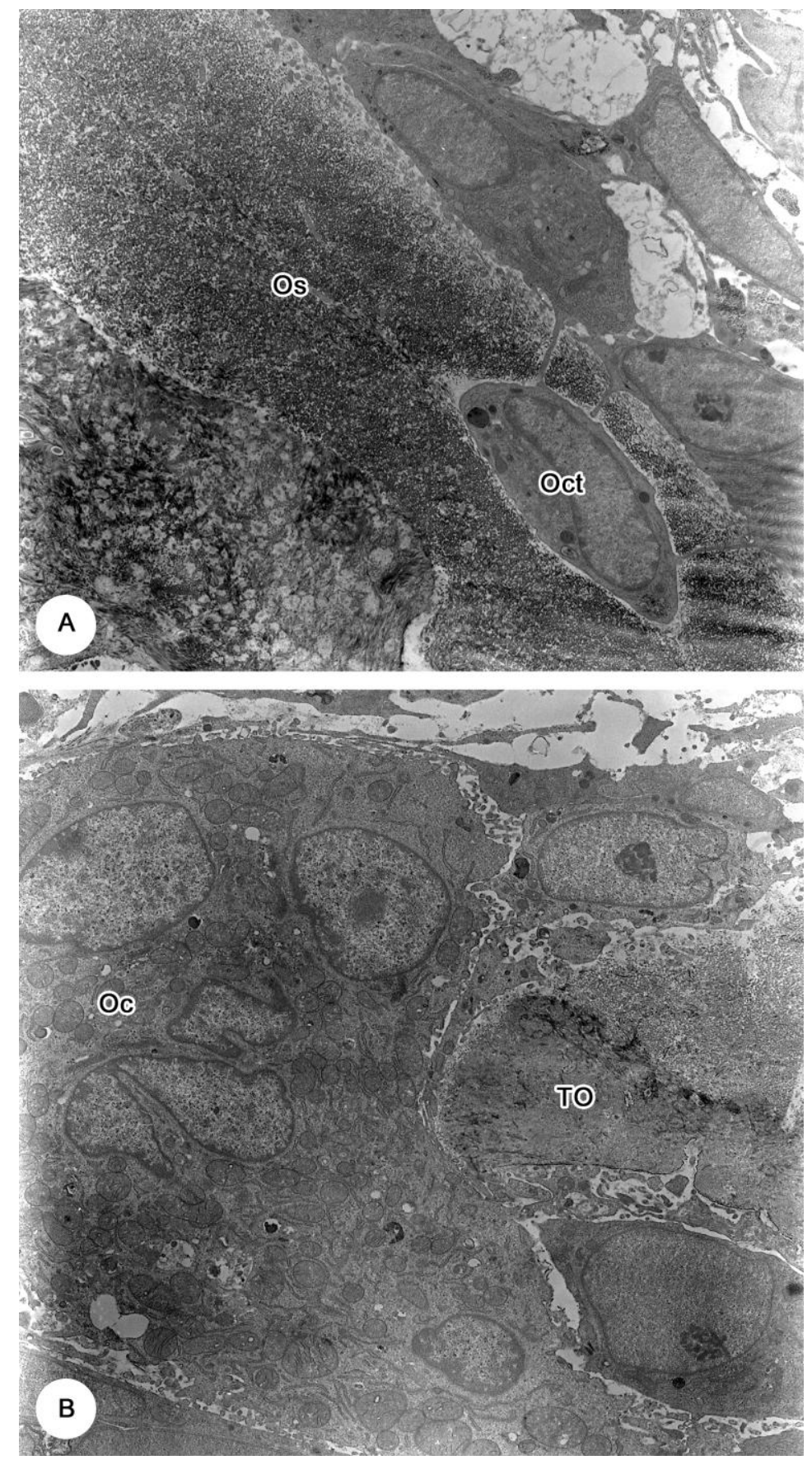

Em A, uma trabécula óssea apresenta espessa camada de osteóide (Os) sobre a mesma, Notar a presença de um osteócito (Oct) envolto pela matriz osteóide, apresentando um prolongamento que se encontra com o prolongamento de um osteoblasto da superfície óssea. Um osteoclasto (Oc) de citoplasma volumoso é observado próximo a uma fina trabécula óssea (TO) que parece ter sido reabsorvida. Entretanto, a célula não apresenta o aparato típico de adesão e reabsorção da matriz. A, 5500X; B, 5000X. 
Figura 30 - Grupo tratado com etidronato, 28 dias. MET.
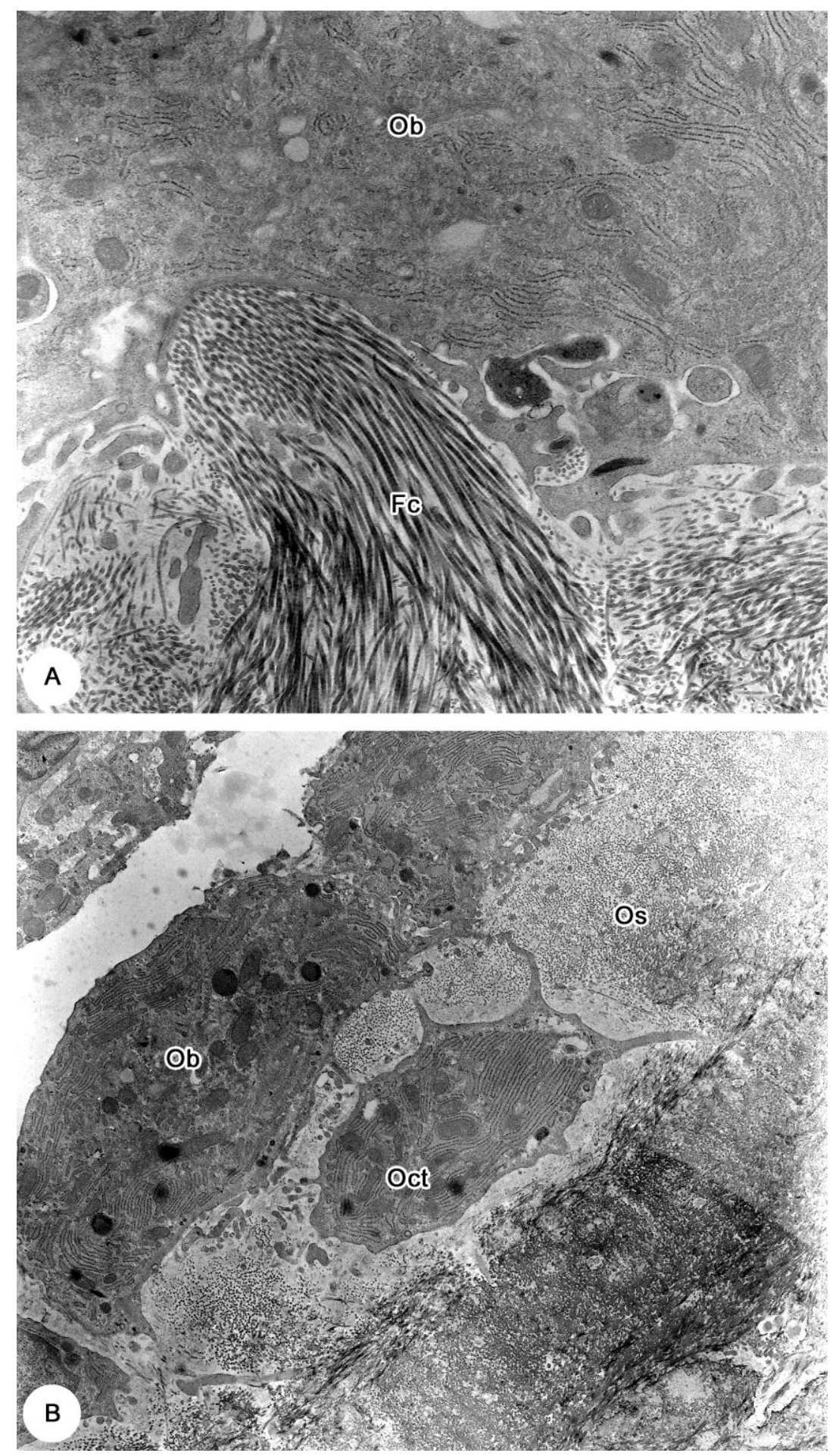

Em A, um osteoblasto $(\mathrm{Ob})$ é observado próximo a um feixe de fibrilas colágenas (fc) da matriz óssea. Foi ainda observada a presença de espessa camada de osteóide sobre as trabéculas ósseas. É apontado um osteócito osteóide (Oct) envolto pela matriz osteóide (Os), cujos prolongamentos se direcionam aos osteoblastos (Ob) na superfície da matriz. A, 16000X;B, 7500X. 
Figura 31 - Grupos tratados com alendronato, etidronato e controle. MET.

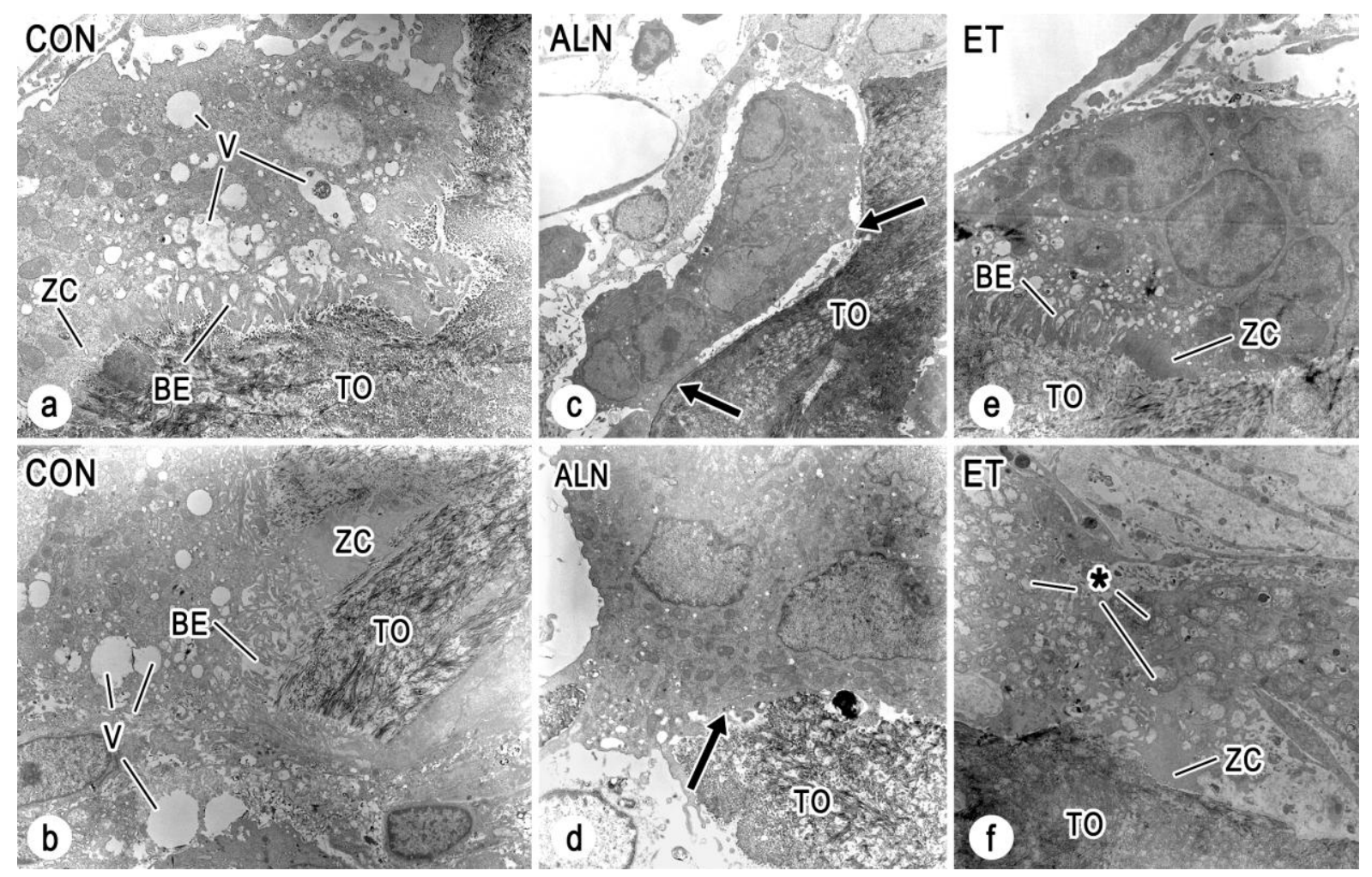

Micrografias eletrônicas de transmissão ilustrando osteoclastos de espécimes controles em $\mathbf{a} \mathbf{e} \mathbf{b}$, tratados com alendronato em $\mathbf{c}$ e $\mathbf{d}$ e tratados com etidronato em e e f. Em a e b, típicos osteoclasto em atividade é observado, apresentando zona clara (ZC), borda em escova (BE) e vacúolos (V) no citoplasma, aderidos a trabéculas ósseas (TO). Em c, um osteoclasto latente se adere a uma trabécula óssea através de curtos podossomos (seta). Em d, é apontado um osteoclasto apresentando uma extensa porção de sua membrana apoiada sobre uma trabécula óssea, porém não apresenta borda em escova. Em e, um osteoclasto aderido a uma trabécula óssea apresenta aparato de reabsorção. Em f, um osteoclasto aderido através de um estreito podossomo, onde se observa uma pequena zona clara. As organelas apresentam-se em degradação (asterisco). Aumentos: a, 4300X; b, e, 2500X; c, 1700X; d, 5100X; f, 2100X 


\subsubsection{Imunodetecção de Osteopontina}

A imunolocalização ultraestrutural da osteopontina (OPN) foi realizada nos espécimes tratados com alendronato e controles.

Nos espécimes tratados, aos quatro dias, a OPN foi localizada na matriz óssea em mineralização do osso alveolar da maxila não descalcificada. Nos espécimes de 4 e 30 dias, partículas de ouro coloidal foram detectadas sobre os glóbulos de mineralização. Muitas superfícies ósseas foram imunomarcadas com ouro coloidal, sendo estas correspondentes a laminae limitans. Também houve marcação positiva para OPN em espaços interfibrilares da matriz e linhas cimentantes. Nos espécimes controles, foi detectada a presença de osteopontina de maneira dispersa pela matriz entre as fibrilas colágenas, e em superfícies ósseas onde osteoclastos estavam aderidos (Figura 32). 
Figura 32 - Imunocitoquímica para OPN. MET.
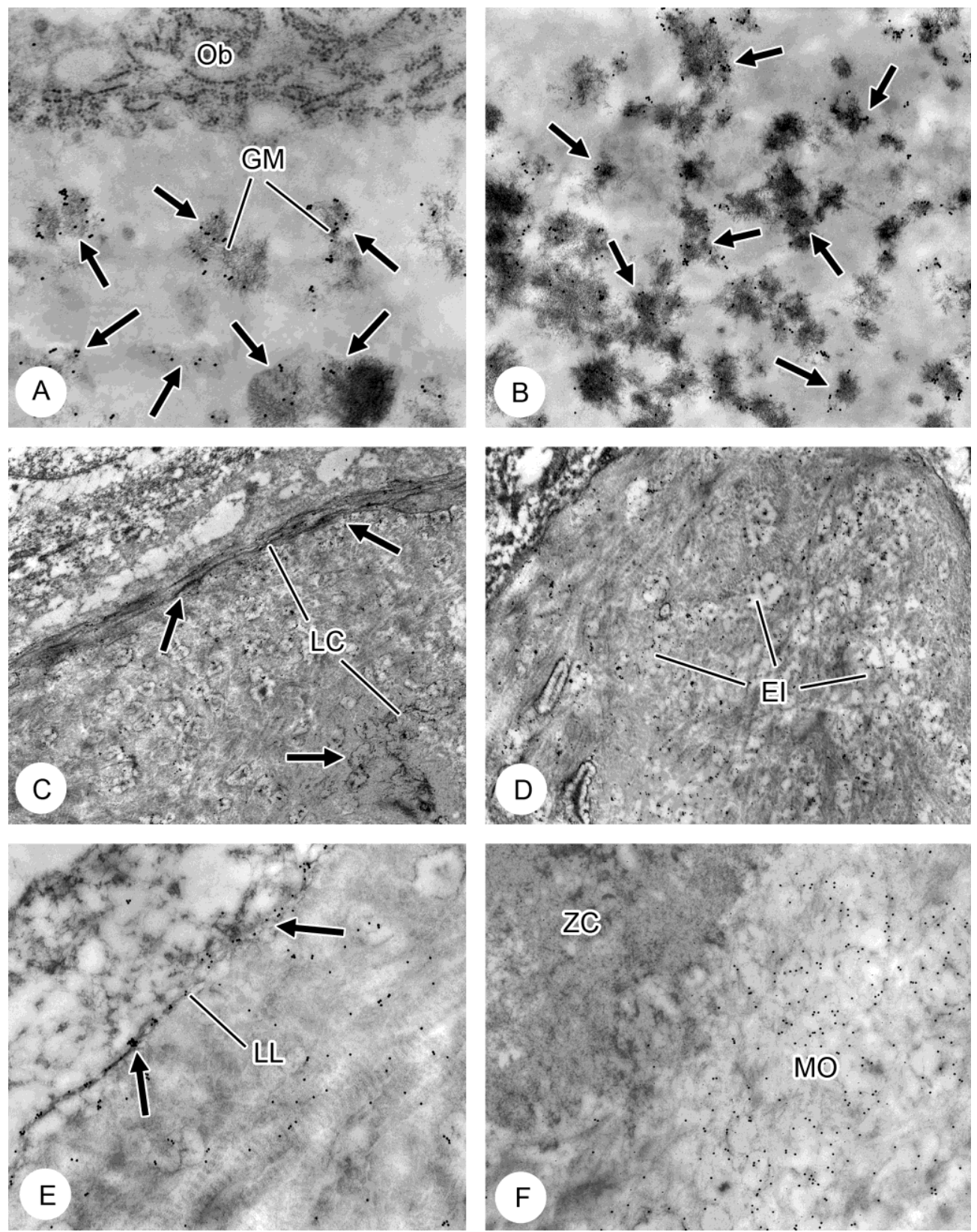

A e B ilustram tecido ósseo não descalcificado incubado com anticorpo anti-OPN, aos 4 dias. Foram visualizados glóbulos de mineralização (GM) apresentando marcação específica com partículas de ouro coloidal (setas). Ob, osteoblasto. Em C e D são mostrados espécimes aos 14 dias. Em C, é observada imunomarcação em linas cimentantes (LC) na matriz. Em D, o osso alveolar apresenta fibrilas colágenas arranjadas de maneira desordenada, com numerosos espaços interfibrilares (EI) imunopositivos para osteopontina. Em E, espécime de 30 dias. Partículas de ouro coloidal são observadas entre as fibrilas colágenas da matriz e na lamina limitans na superfície (setas). Em F é ilustrado um espécime controle aos 30 dias, no qual se observa a zona clara (ZC) de um osteoclasto aderido à matriz óssea (MO) imunopositiva para osteopontina. A, 30000X; B, 24000X; C e D, 13000X; E, 22000X; F, 14000X 


\subsubsection{Imunodetecção de Sialoproteína Óssea}

A imunolocalização ultraestrutural da sialoproteína óssea (BSP) foi realizada nos espécimes tratados com alendronato e controles.

Em espécimes tratados com alendronato de quatro dias, foi observada imunomarcação para BSP com partículas de ouro coloidal dispersas entre as fibrilas colágenas, estando algumas delas em glóbulos de mineralização. Nos demais períodos, a imunomarcação foi discreta em espaços interfibrilares da matriz e linhas cimentantes de aposição. Em espécimes controles, a imunomarcação para BSP foi encontrada distribuída de maneira esparsa pela matriz, entre as fibrilas colágenas, e em trabéculas ósseas às quais osteoclastos estavam aderidos (Figura 33). 
Figura 33 - Imunocitoquímica para BSP. MET.
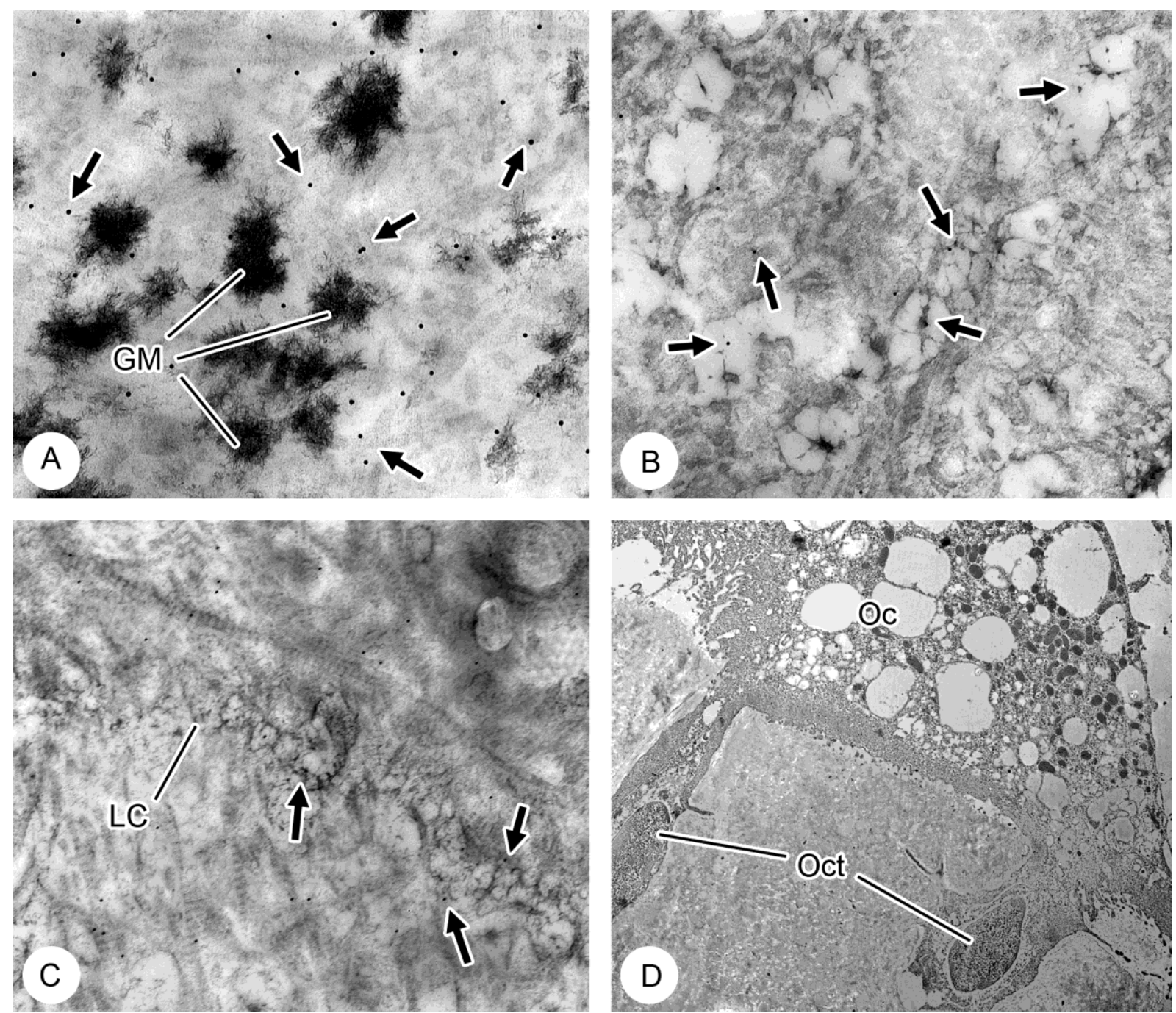

Em A, espécime tratado com alendronato não descalcificado aos 4 dias apresentou diversos glóbulos de mineralização (GM) na matriz. As partículas de ouro coloidal indicando a localização da BSP (setas) estiveram localizadas em meio às fibrilas colágenas, de maneira esparsa pela matriz. Em B, aos 14 dias, imunomarcação foi observada nos espaços interfibrilares da matriz (setas). Em C, espécime de 30 dias apresenta partículas de ouro indicando presença de BSP em uma linha cimentante (LC). Em D, espécime controle aos 14 dias apresenta um osteoclasto (Oc) ativo reabsorvendo matriz óssea marcada de forma esparsa para BSP. Oct, osteócitos. A, 25000X; B, 17000X; C, 15000X; D, 2500X. 


\subsection{Imunodetecção de OPG, RANK e RANKL}

As imunofluorescências foram utilizadas para analisar a presença das proteínas OPG, RANK e RANKL no osso alveolar da porção oclusal da cripta óssea. As análises foram feitas em animais tratados com alendronato cujos cortes foram incubados com os anticorpos anti-RANK, anti-RANKL e anti-OPG para imunodetecção em microscópio confocal de varredura a laser. Os anticorpos primários foram incubados posteriormente incubados com anticorpo secundário conjugado com Сy3, que apresenta fluorescência vermelha. Os núcleos foram marcados com anticorpo de fluorescência verde.

Aos quatro dias, foi observada marcação aparentemente mais intensa para OPG no osso alveolar do teto da cripta óssea de espécimes controles do que nos tratados com alendronato. Aos oito dias, a marcação observada nas células de revestimento ósseo de ambos os grupos apresentou intensidade semelhante (Figura 34). A partir do décimo quarto dia, foram analisados apenas espécimes tratados com alendronato, pois nos controles a via eruptiva havia se formado. Aos catorze dias, foi verificada a presença de marcação para OPG com intensidade semelhante à dos períodos anteriormente analisados, sendo observada diminuição na intensidade da marcação aos vinte e um e vinte e oito dias (Figura 35). 
Figura 34 - Imunofluorescência para OPG. Microscopia confocal.
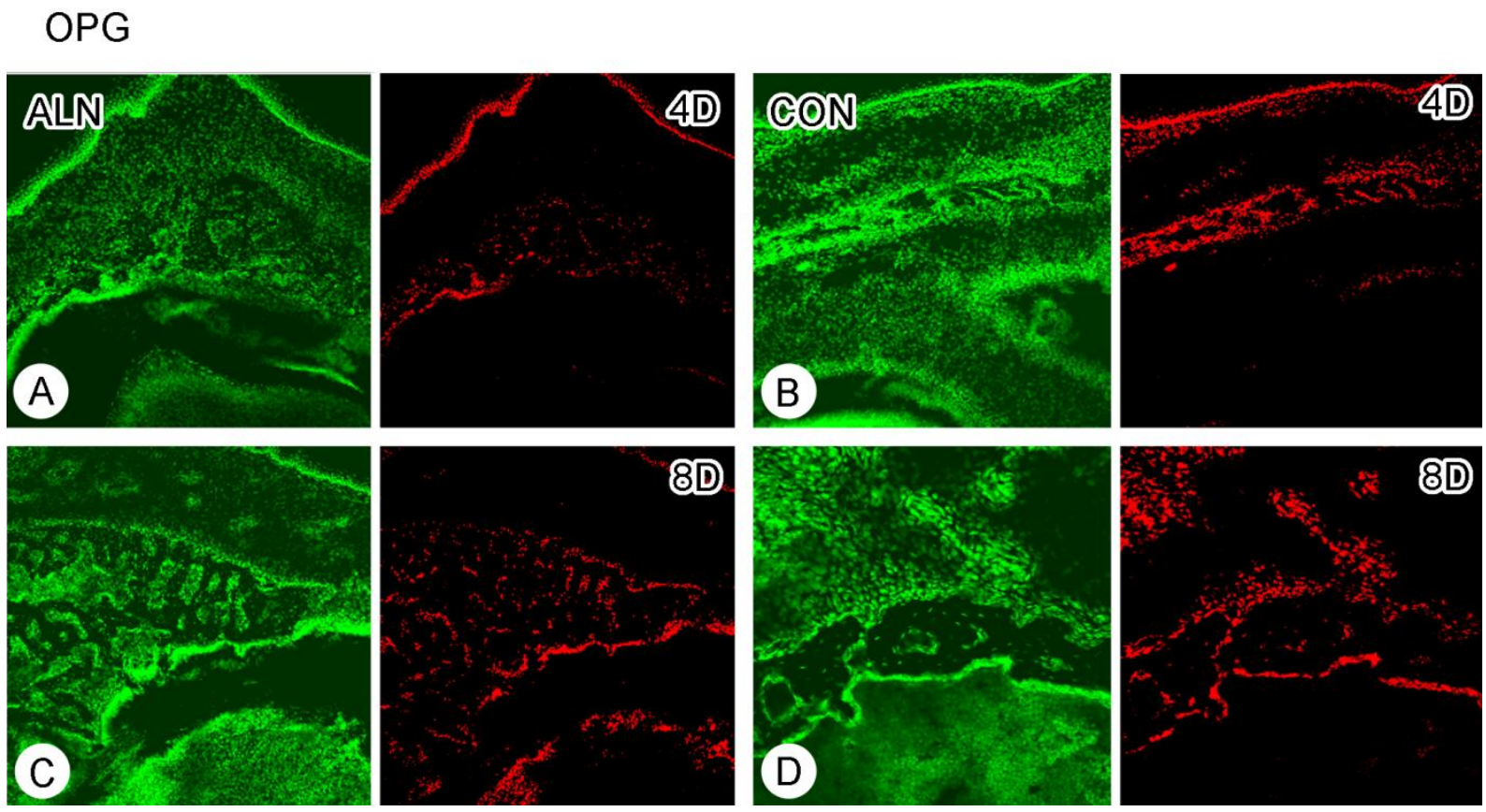

Em A, espécime tratado com alendronato com 4 dias apresentando imunomarcação para OPG (fluorescência vermelha) no osso alveolar do teto da cripta óssea menos intensa que os espécimes controles, observados em B. Em C, A imunomarcação para OPG aos 8 dias de idade apresenta intensidade semelhante à observada no grupo controle, em D. A e B, 10X; C e D, 20X. 
Figura 35 - Imunofluorescência para OPG. Microscopia confocal.

OPG
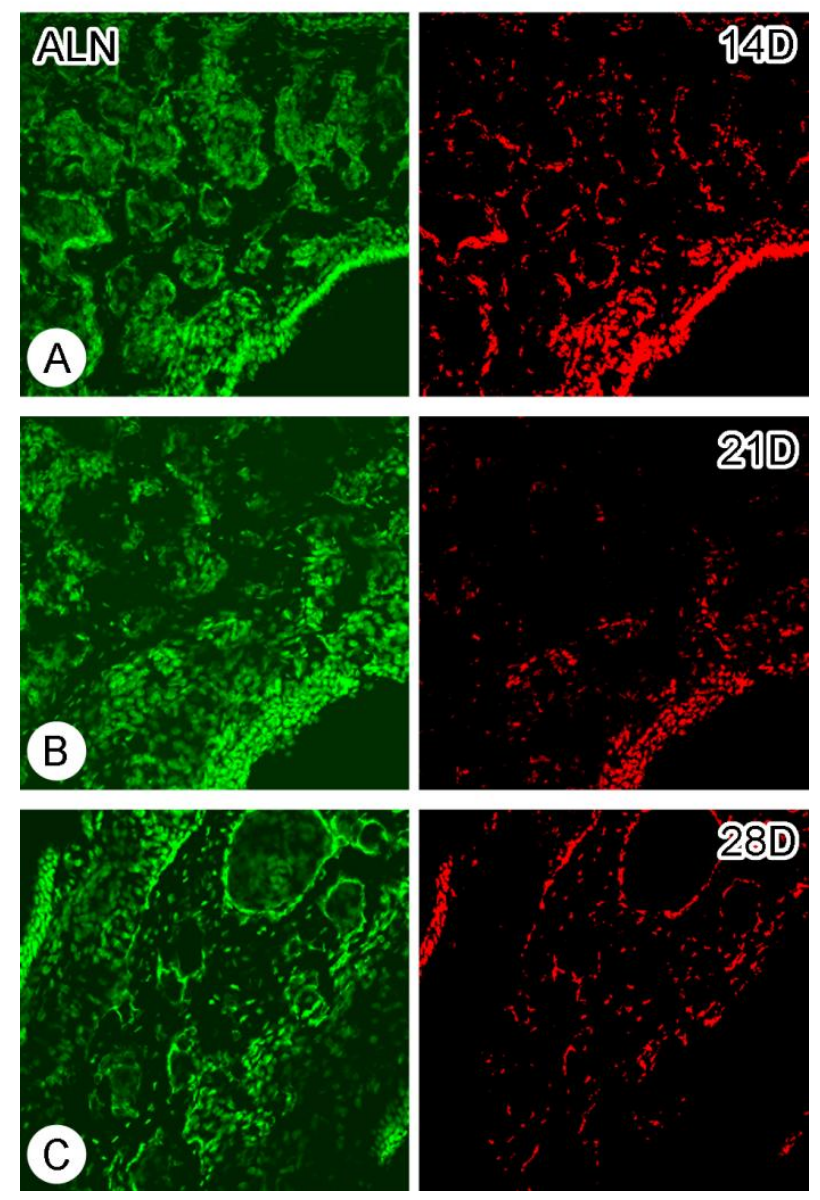

Em A, espécime tratado com alendronato com 14 dias apresentando imunomarcação para OPG no osso alveolar do teto da cripta óssea (fluorescência vermelha) mais intensa do que nos espécimes aos 21 dias, em B, e 28 dias, em C. Aumentos, 20X. 
Figura 36 - Imunofluorescência para RANK. Microscopia confocal.
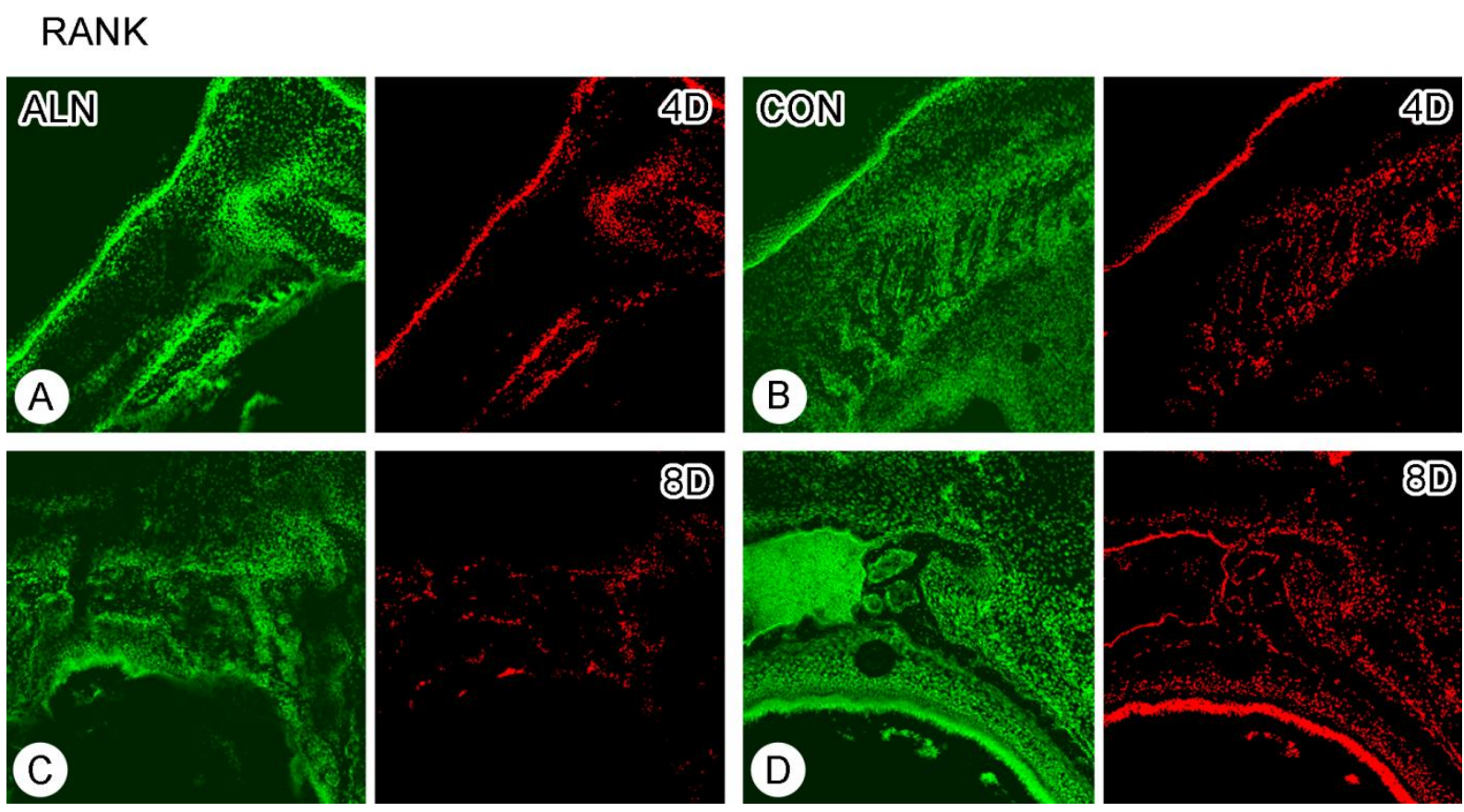

A imunomarcação para RANK pode ser observada como pontos de fluorescência mais intensa ao redor das trabéculas ósseas na região oclusal da cripta e nos espaços entre as trabéculas. Em A, aos 4 dias, observam-se algumas regiões com marcação intensa no espécime tratado; no controle, em $B$, também são observados pontos com marcação intensa ao redor das trabéculas. $\mathrm{Em} \mathrm{C}$, aos 8 dias, observa-se marcação menos intensa que no controle, ilustrado em D. A, B e D, 10X; C, 20X. 
Figura 37 - Imunofluorescência para RANK. Microscopia confocal.

RANK
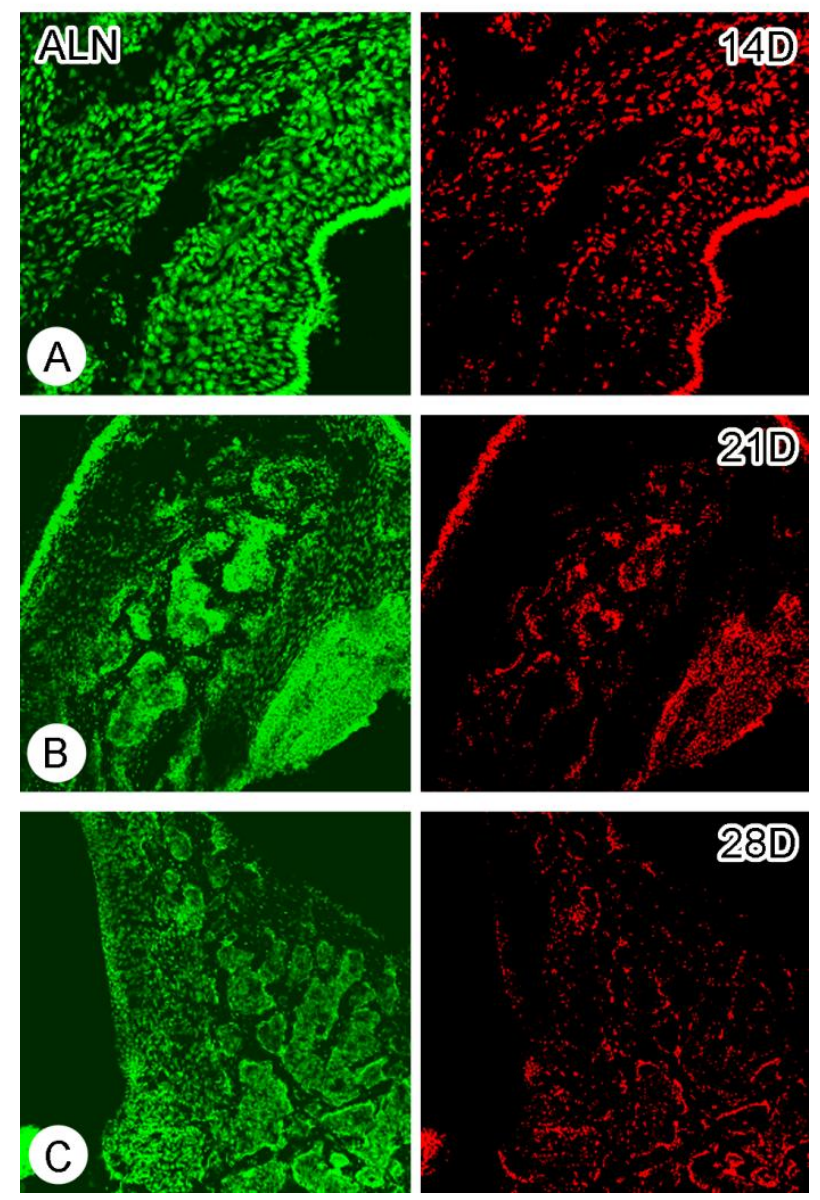

Em A, espécime tratado com alendronato aos 14 dias apresentando marcação difusa. Em B, aos 21 dias, foram observados alguns pontos com marcação de maior intensidade ao redor das trabéculas ósseas, sendo o mesmo padrão observado em $\mathrm{C}$, aos 28 dias. A, 20X; B e C, $10 \mathrm{X}$. 
Figura 38 - Imunofluorescência para RANKL. Microscopia confocal.

\section{RANKL}
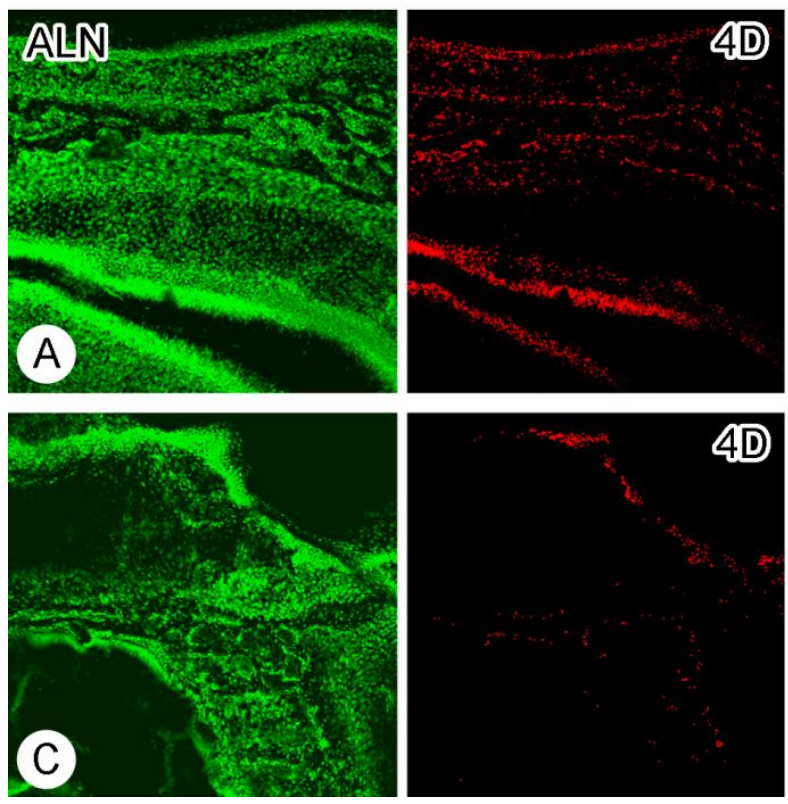
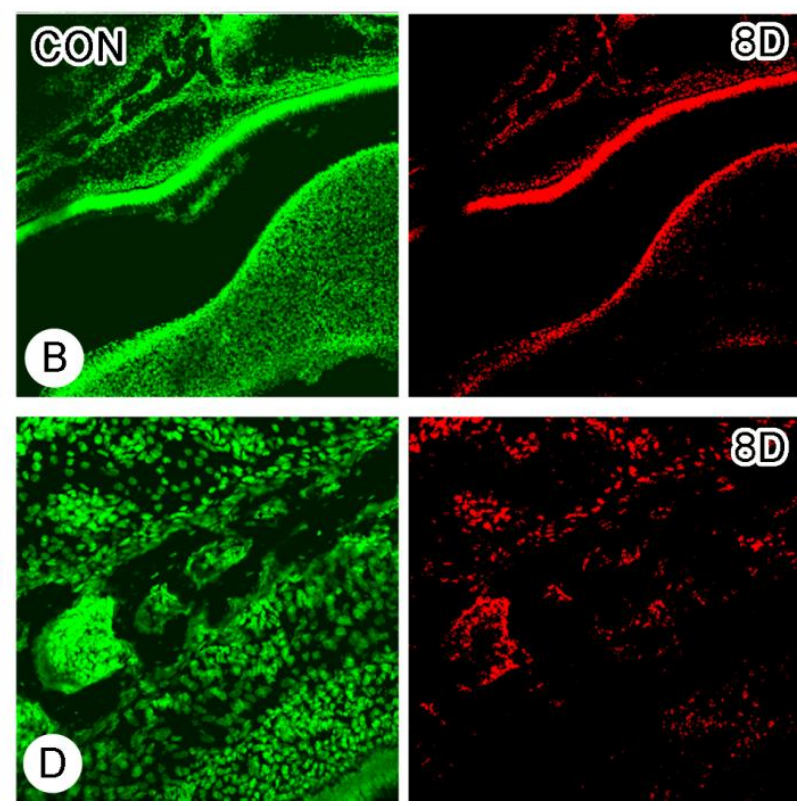

Aos 4 dias, os espécimes controles apresentando marcação mais intensa ao redor das trabéculas ósseas e na região do folículo dentário do que o tratado com alendronato. Aos 8 dias, a marcação para RANKL também é mais intensa no espécime controle do que no tratado com alendronato. A e D, 20X; B e C, 10X. 
Figura 39 - Imunofluorescência para RANKL. Microscopia confocal.

\section{RANKL}
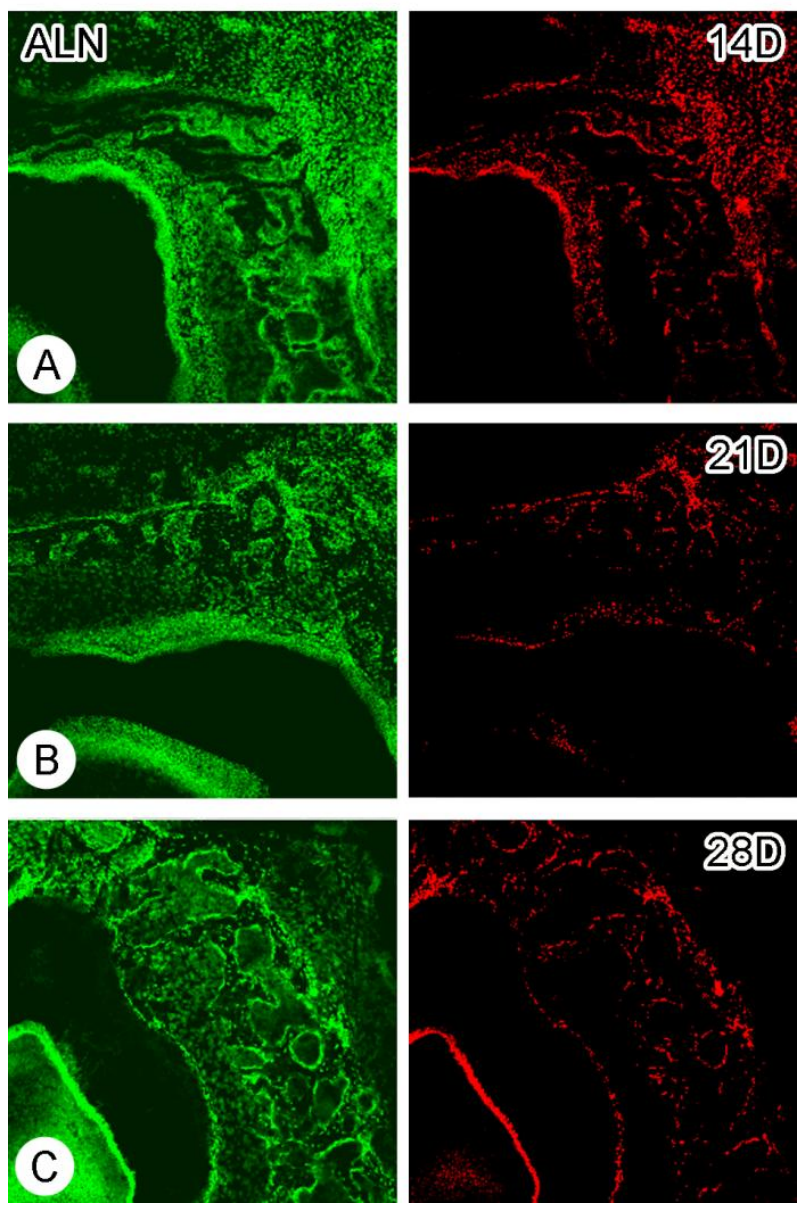

Os espécimes tratados com alendronato aos 14, 21 e 28 dias apresentam marcação intensa para RANKL no tecido ósseo do teto da cripta alveolar. Aumentos, 10X. 


\subsection{Western Blotting}

A expressão das proteínas RANK, RANKL e OPG foi detectada na porção oclusal da cripta óssea aos quatro e oito dias em espécimes tratados com alendronato e controles; aos catorze, vinte e um e vinte e oito dias, a expressão destas proteínas foi analisada somente nos grupos tratados com alendronato.

A intensidade das bandas para OPG foi semelhante em todos os grupos. O mesmo padrão foi observado na análise das bandas correspondentes a RANK. A proteína RANK foi fracamente detectada, porém com intensidades semelhantes em ambos os grupos ALN e CON, e em todos os períodos estudados. Não houve detecção de bandas correspondentes a RANKL nos espécimes tratados com alendronato em nenhum dos períodos analisados. Nos controles, bandas para RANKL foram detectadas (Figura 40). 
Figura 40 - Western Blotting
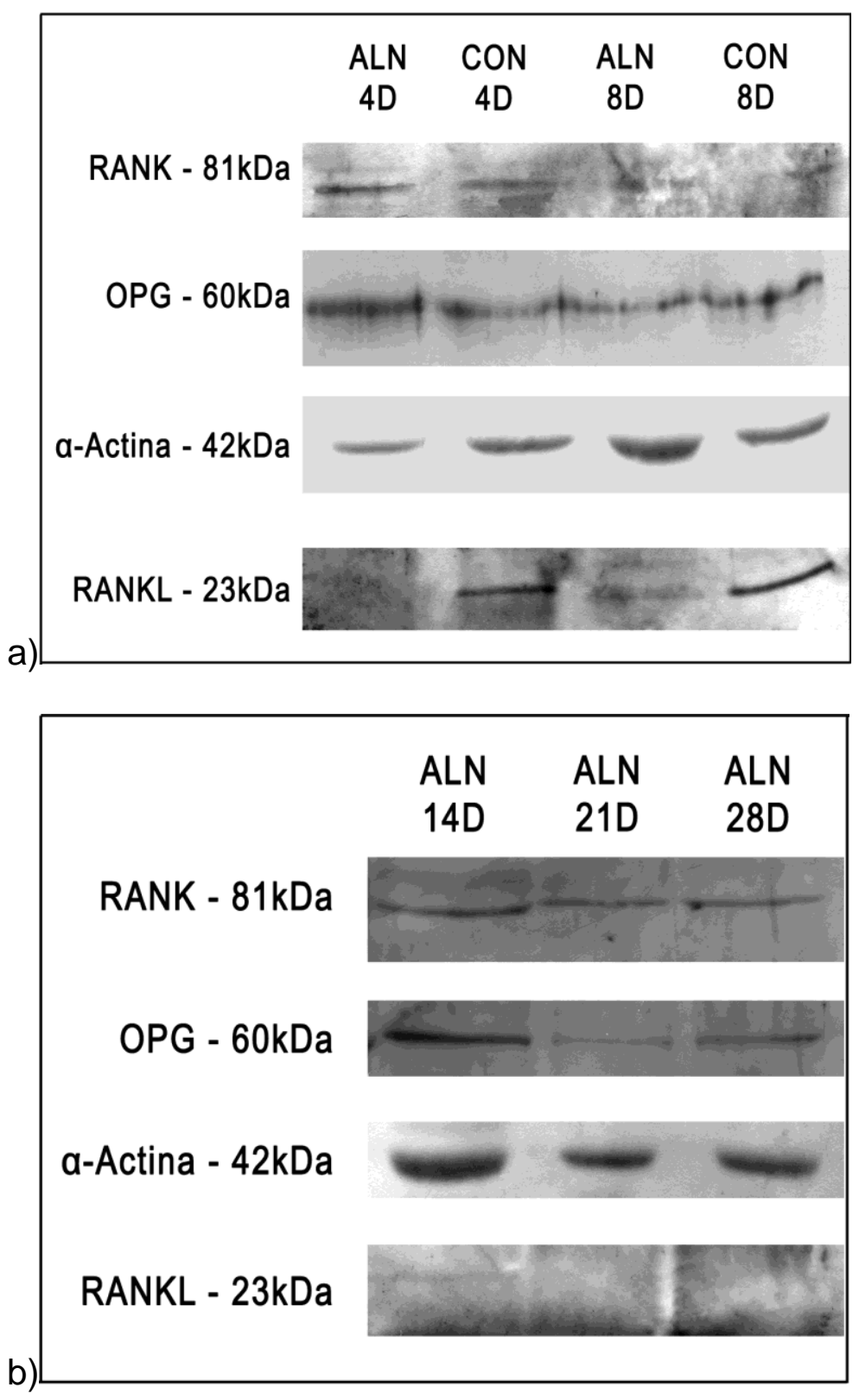

São ilustradas as bandas correspondentes aos pesos moleculares de RANK, OPG e RANKL, sendo a actina utilizada como controle. Em a, analizando-se espécimes tratados e controles aos 4 e 8 dias, observaram-se bandas semelhantes para RANK. Para OPG, as bandas apresentaram intensidades semelhantes entre si. Para RANKL, foi observada reação positiva apenas nas bandas dos espécimes controles em ambos os períodos. Em b, espécimes de 14, 21 e 28 dias apresentaram bandas com intensidade semelhante prara RANK e OPG. Não houve detecção de bandas para RANKL nos grupos ALN em todos os períodos analisados. 


\subsection{Células RAW 264.7}

As células da linhagem RAW-264.7 suplementadas com RANKL originaram células gigantes multinucleadas e TRAP positivas em todas as condições de cultivo (controle, 1 ou $10 \mu \mathrm{M}$ de alendronato sódico) (Figura 41).

Ao analisar os dados da contagem de células TRAP positivas, não foi observada diferença significante entre as diferentes doses de alendronato e 0 controle no número de células TRAP positivas mononucleadas e multinucleadas (com 2 a 4 núcleos); entretanto, o grupo tratado com $1 \mu \mathrm{M}$ apresentou diminuição significativa no número de células gigantes (com 5 núcleos ou mais) em realção ao controle e ao tratado com $10 \mu \mathrm{M}$ (Gráfico 4). 
Figura 41 - Células RAW 264.7 tratadas com alendronato. TRAP.
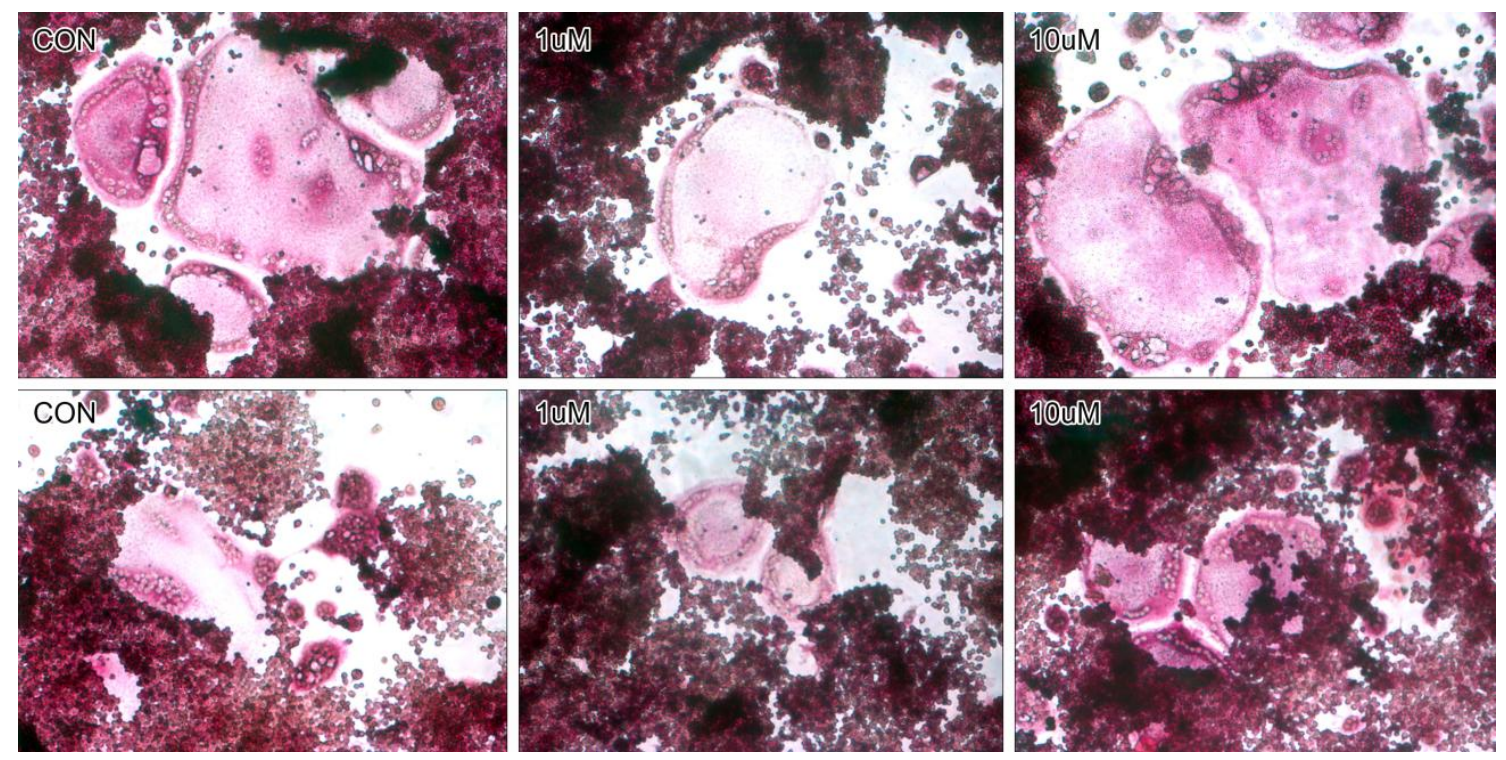

Células gigantes TRAP positivas observadas nos grupos controle e tratados com alendronato nas concentrações de 1 e $10 \mu \mathrm{M}$. Aumentos:200X

Gráfico 4 - Número de células TRAP positivas e classificação quanto ao número de núcleos.

MONONUCLEARES

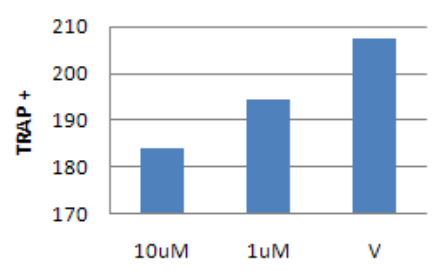

MULTINUCLEARES

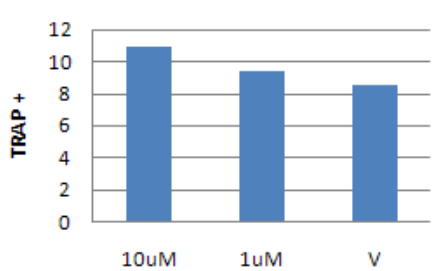

GIGANTES

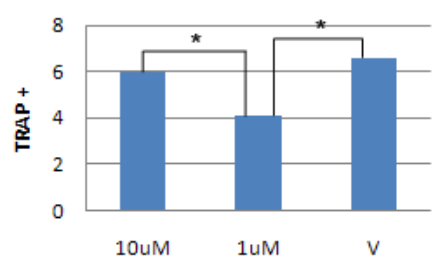

O tratamento com alendronato sódico não ocasionou diferença estatisticamente significante no número de células mononucleares e multinucleares entre os controles e os tratados em diferentes doses. Culturas tratadas com $1 \mu \mathrm{M}$ de alendronato apresentaram número reduzido de células gigantes. ${ }^{*} p \leq 0,05$. 


\subsection{Células da medula óssea de camundongos}

As células obtidas a partir da medula de camundongos suplementadas com vitamina $D_{3}$, quando tratadas com diferentes doses de alendronato, apresentaram diminuição significante do número de células gigantes (com 5 núcleos ou mais) em relação ao controle. Houve também diminuição do número de células multinucleadas, porém a diferença apresentou significância apenas entre os grupos tratados com 100nM e o controle (Figura 42).

Ao contarmos as células remanescentes na placa, observamos que o grupo tratado com $100 \mu \mathrm{M}$ apresentou significante redução no número de células mononucleadas TRAP-positivas. Este mesmo grupo não apresentou células multinucleadas ou gigantes. Ao compararmos o número de células gigantes dos grupos tratados com o controle, observamos que todos apresentaram redução significativa (Gráfico 5). 
Figura 42 - Células da medula óssea de camundongos tratadas com alendronato. TRAP.
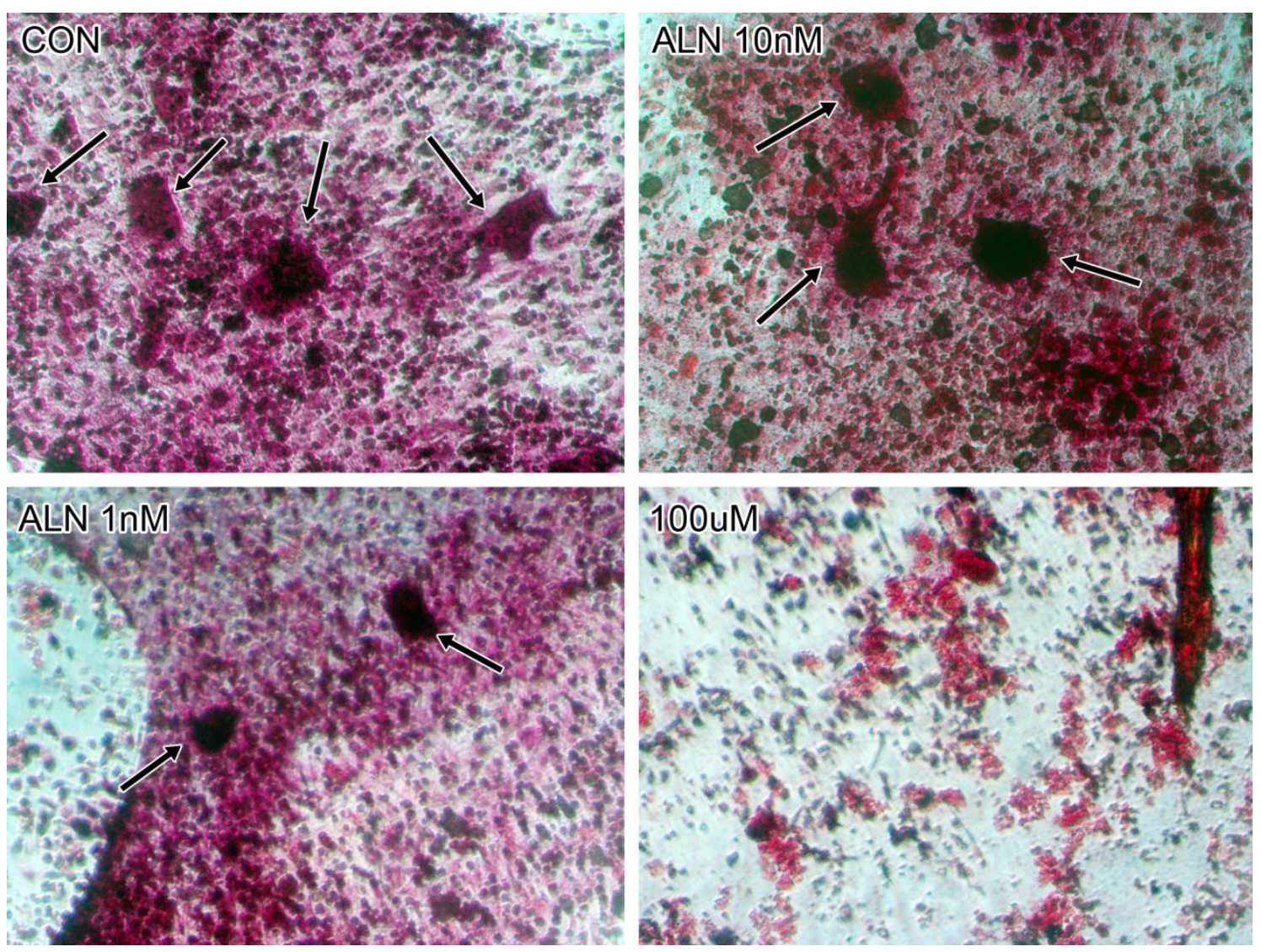

Células multinucleadas TRAP positivas (setas) foram observadas em cuturas de medula de camundongo sem tratamento e nas tratadas com $1 \mathrm{nM}$ e $10 \mathrm{nM}$ de alendronato. As délulas de medula tratadas com $100 \mu \mathrm{M}$ de alendronato apresentaram somente células mononucleares TRAP positivas. Aumentos: 200X.

Gráfico 5 - Número de células TRAP positivas e classificação quanto ao número de núcleos
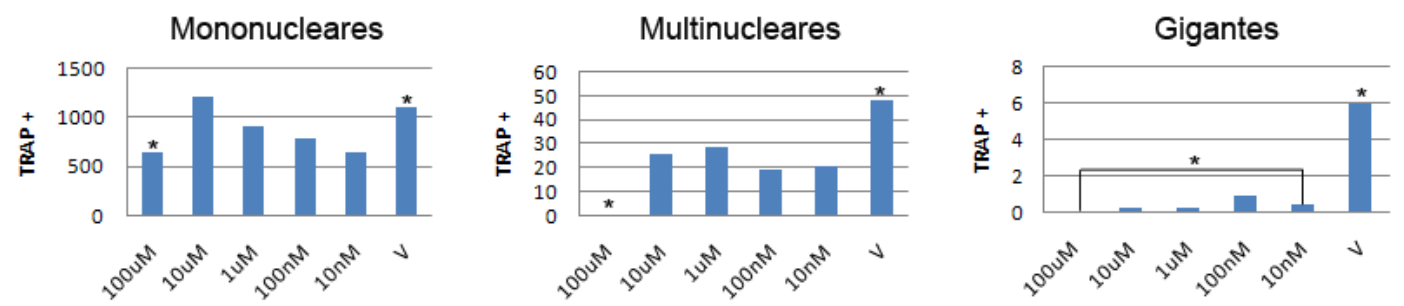

As células de medula óssea tratadas com $100 \mu \mathrm{M}$ de alendronato originaram menos células TRAP positivas mononucleares e multinucleares. O tratamento com alendronato diminuiu a formação de células gigantes TRAP positivas em culturas sob todas as doses utilizadas. * $p \leq 0,05$. 
5.6.1 Análise dos discos de osso em MEV

As células obtidas da medula de camundongos e cultivadas sobre discos de osso cortical bovino sem alendronato apresentaram numerosas lacunas de reabsorção após 5 dias de cultivo. Os discos sobre os quais as células da medula óssea foram cultivadas e tratadas com $10 \mathrm{nM}$ de alendronato, a menor dose utilizada, apresentaram poucas e rasas lacunas de reabsorção. Os discos cujas células cultivadas foram tratadas com $100 \mu \mathrm{M}$ de alendronato, a maior dose utilizada, por sua vez, não apresentaram nenhuma lacuna de reabsorção (Figura 43). 
Figura 43 - Análise das lacunas de reabsorção formadas pelas células cultivadas.
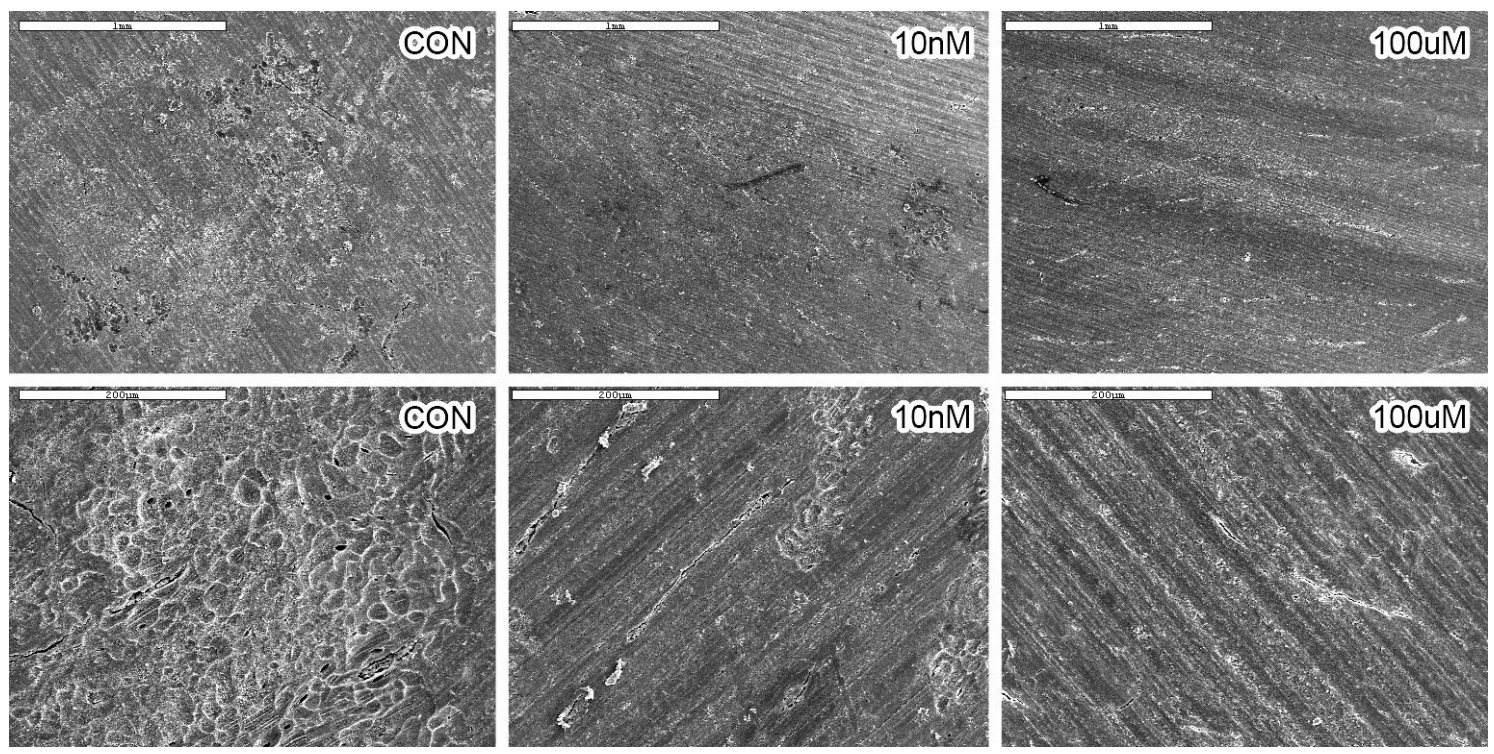

Os discos de osso sobre os quais foram cultivadas células da medula óssea na ausência de tratamento apresentaram numerosas lacunas de reabsorção. Nos discos de osso cujas células cultivadas foram tratadas com $10 \mathrm{nM}$ de alendronato foram observadas algumas lacunas de reabsorção rasas e pouco numerosas. Nos discos cujas células cultivadas receberam tratamento com $100 \mu \mathrm{M}$ de alendronato não foram detectadas lacunas de reabsorção. 
O presente estudo teve como finalidade induzir a inibição da atividade reabsortiva de osteoclastos através da administração de dois bisfosfonatos (alendronato e etidronato) a ratos jovens, buscando primeiramente compreender como o fenômeno da erupcão do primeiro molar é alterado e, consequentemente, buscar elucidar quais eventos são fundamentais à movimentação eruptiva.

Nos espécimes tratados com alendronato, apesar do aumento do número de células clásticas, foi notado que a maioria destes apresentou aparência latente. Com isso, o processo de remodelação óssea apresentou sinais de alteração, e as trabéculas ósseas se desenvolveram de forma desorganizada ao redor do germe dentário do primeiro molar. Com isso, puderam ser observadas alterações no folículo dentário e na bainha epitelial radicular devido ao crescimento de trabéculas ósseas em direção ao germe dentário. $O$ alendronato impediu que os osteoclastos da cripta fossem ativados, apesar de não impedir seu recrutamento e fusão. A diminuição da reabsorção óssea impediu a formação da via eruptiva e da remodelação da base da cripta durante a formação radicular, o que provocou a ausência tanto de erupção quanto de formação radicular.

O etidronato apresentou efeitos diferentes sobre o tecido ósseo, o processo de osteoclastogênese e o desenvolvimento do primeiro molar daqueles observados com o alendronato. $\mathrm{O}$ etidronato ocasionou a diminuição do número de osteoclastos durante a erupção intra-óssea, bem como alterou a proporção entre as células ativadas e latentes. O processo de reabsorção durante a remodelação óssea da cripta parece ter ocorrido de forma mais lenta, e pontos de anquilose foram observados na raiz em desenvolvimento. Tais eventos resultaram no atraso da erupção dentária e da formação radicular.

Tal diferença entre o efeito dos diferentes bisfosfonatos utilizados no presente estudo na osteoclastogênese e remodelação óssea que ocorre durante o processo eruptivo pode ser justificada pela diferença entre a natureza e estrutura química de ambos. O etidronato, bisfosfonato não nitrogenado e de primeira geração, apresenta potência anti-reabsortiva quinhentas vezes menor que a do alendronato (Vasikaran, 2001). Além disso, seus mecanismos de ação sobre o tecido ósseo são diferentes. 
Enquanto o alendronato inibe modificações pós traducionais essenciais para a atividade de GTPases Ras, Rho e Rac e Rab (Russell, 2006), essenciais aos mecanismos de formação do aparato de reabsorção de osteoclastos (Jurdic et al., 2006; Ory et al., 2008; Taylor et al., 2011; Itzstein et al., 2011), o etidronato é metabolizado no osteoclasto originando análogos tóxicos do ATP, inibindo sua função e induzindo a morte celular (Russell, 2006).

Baseando-se na quantidade, distribuição e atividade dos osteoclastos encontradas nos diferentes grupos nas diferentes fases da erupção, foi observada maior atividade reabsortiva nos espécimes tratados com etidronato do que nos tratados com alendronato, o qual não impediu a formação da via eruptiva no osso alveolar; entretanto, o menor número de osteoclastos na porção oclusal da cripta óssea durante a erupção intra-óssea pode ter ocasionado o atraso da erupção em relação ao grupo controle. Pode-se considerar, dessa forma, que o etidronato não impediu a ativação de osteoclastos com a mesma eficácia que isto ocorreu no grupo tratado com alendronato, porém a presença de menos células em determinadas fases do processo eruptivo pode indicar alguma interferência no mecanismo de osteoclastogênese, além da provável indução da morte celular destas células devido a seu efeito citotóxico.

Com relação ao efeito do alendronato sobre os osteoclastos, a presença de numerosos osteoclastos TRAP positivos em estado latente observados nas etapas da erupção dentária analisadas neste estudo e o impedimento eficaz da reabsorção óssea e da erupção dentária, nos levou a testar, in vitro, o efeito de diferentes doses desta droga em células precursoras de osteoclastos. Observou-se que o alendronato não impediu a fusão dos precursores da linhagem RAW 264.7, originando células osteoclasto-like TRAP positivas multinucleadas e gigantes. Uma vez constatado que o mecanismo de fusão e diferenciação não fora impedido, foi feito o cultivo de células da medula do fêmur e da tíbia de camundongos sobre discos de osso cortical bovino, em meio contendo alendronato. Previamente às culturas, foram feitos testes preliminares para detecção do alendronato no meio no momento da adição de alendronato marcado por O-phtalaldehyde (OPA), que permite a detecção do alendronato em espectofotômetro (metodologia adaptada ao protocolo sugerido por Al Deeb et al., 2004). Foi comprovado no teste que a droga, nas doses utilizadas, foi 
totalmente incorporada à matriz óssea mineralizada (resultados não mostrados). Em seguida, foi também feito teste, após o prévio tratamento com alendronato, para avaliação da liberação da substância a novo meio. Observamos não haver liberação do fármaco ao meio, ou seja, a substância permaneceu ligada ao osso durante o experimento. Quando cultivadas células nas condições anteriormente mencionadas, foi observada diminuição da reabsorção dos discos nos grupos tratados. Podemos inferir que a menor reabsorção ocorreu devido à incorporação do alendronato pelas células clásticas originadas, as quais a partir do momento que degradaram uma porção da matriz, ainda que muito superficial, incorporaram a droga e foram inativadas. A droga liberada desta forma provavelmente foi disponibilizada às demais células clásticas aderidas ao plástico ao redor, as quais apresentaram diminuição no número de células gigantes. No entanto, o efeito da droga e da vitamina D3 adicionada ao meio sobre as células mesenquimais presentes na cultura podem ter influenciado nos resultados.

Ao analisarmos os osteoclastos ultraestruturalmente, foi observado que o alendronato impediu que estas células fossem ativadas tanto nos animais tratados quanto nos experimentos in vitro. Apesar das doses utilizadas nas diferentes abordagens de estudo não serem comparáveis, ambas mostraram que o alendronato não impediu a fusão e diferenciação de osteoclastos, porém inativou o aparato de reabsorção das células.

O efeito inibidor do alendronato sobre os osteoclastos ocasionou alterações na remodelação óssea. O mecanismo de remodelação óssea requer a coordenação e o equilíbrio entre as funções de osteoclastos e osteoblastos de forma sequencial, sendo conhecido como acoplamento ou coupling. Durante o crescimento ósseo, incluindo o dos ossos maxilares, este processo se dissocia havendo predomínio de formação óssea. Entretanto, a formação óssea por osteoblastos de maneira coordenada é dependente de prévia reabsorção por osteoclastos, em um mecanismo que envolveria a liberação de citocinas como membros da superfamília do TGF $\beta$ e IGFs (Karsdal et al., 2007). Os osteoclastos também expressam e secretam a osteopontina sobre a matriz óssea após a reabsorção, sendo esta considerada um fator parácrino durante a remodelação óssea (Chellaiah et al., 2003). O osso alveolar de ratos tratados com alendronato apresentou trabéculas 
formadas de maneira desorganizada, cuja matriz apresentou características ultraestruturais de osso primário. Em todos os períodos estudados, a matriz óssea de animais tratados com alendronato apresentou arranjo desorganizado de fibrilas colágenas e muitos osteócitos englobados aleatoriamente na matriz, como é característico ocorrer durante o processo de ossificação. A distribuição de osteopontina e sialoproteína óssea analisada pelo método da imunocitoquímica ultra-estrutural mostraram a presença destas proteínas em espaços interfibrilares da matriz e em linhas cimentantes. Estes aspectos demonstram que, mesmo sendo observados alguns sinais de atividade reabsortiva por osteoclastos, o processo não ocorreu de forma coordenada de modo a promover a remodelação óssea necessária.

A formação desorganizada de trabéculas ósseas ao redor do germe dentário dos animais tratados com alendronato sódico ocasionou o contato entre o osso e o folículo dentário e, em alguns pontos, com células do órgão do esmalte e até mesmo a matriz do esmalte. Nos primeiros estudos utilizando-se o tratamento de ratos com bisfosfonatos como modelo de estudo da erupção dentária foi utilizado o pamidronato, bisfosfonato nitrogenado com potência superior à do etidronato e inferior à do alendronato, que ocasionou o atraso da erupcão dentária. Apesar do atraso do processo eruptivo, não foram observadas deformidades no dente erupcionado, e os osteoclastos analisados apresentaram aparato de reabsorção com características normais (Grier e Wise, 1998). No presente estudo, o emprego do alendronato sódico em altas doses diárias foi capaz de interromper efetivamente o processo eruptivo até o trigésimo dia de vida, ocasionando a anquilose da coroa do molar e ausência de formação radicular. Outro bisfosfonato nitrogenado, o ácido zoledrônico, demonstrou efeito inibidor da erupção e formação radicular de molares de ratos, além de ocasionar o surgimento de estruturas semelhantes a odontomas (Hiraga et al., 2010).

Estudos anteriores relatam alterações no processo eruptivo (Beertsen et al., 1985), inibição da formação de cemento acelular (Alatli e Hammarström, 1996), redução do comprimento das raízes de molares e a formação de anquilose dentoalveolar na região da furca de camundongos e ratos tratados com alendronato sódico (Alatli et al., 1997). Tais características também foram observadas nos 
espécimes tratados com etidronato no presente estudo. Os estudos descritos sobre o efeito do etidronato sobre a formação dentária utilizaram em sua maioria o incisivo do rato como modelo experimental, e muitos destes abordaram alterações no mecanismo de mineralização da matriz de esmalte e dentina induzida por este fármaco (Brandsten et al., 1995; Sakai et al., 1999; Fuangtharnthip et al., 2000, entre outros). Foi observado no presente estudo, além do atraso do processo eruptivo e da alteração do número de osteclastos TRAP positivos, a presença de espessa camada de osteóide sobre a matriz mineralizada no tecido ósseo. Estudos afirmam que o etidronato impede a progressão da mineralização aposicional da matriz óssea neoformada em ratos ( $\mathrm{Li}$ et al., 2008). Os osteócitos aprisionados nesta matriz não mineralizada em mandíbula de ratos não sofrem maturação, sendo considerada a mineralização da matriz um evento fundamental para que a maturação de osteócitos ocorra (Irie et al., 2008).

Nos animais tratados com alendronato foram observados diversos pontos ao redor do germe dentário em que o folículo dentário foi comprimido por trabéculas ósseas. Tal fato pode ter contribuído com a alteração do número de osteoclastos e a inativação de grande parte destes, pois diversos estudos demonstram o papel do folículo dentário e fatores por ele secretados como reguladores da osteoclastogênese durante a erupção dentária. Experimentos em que a porção oclusal do folículo dentário fora removida demonstraram ausência de formação de via eruptiva e impedimento da erupcão dentária (Marks e Cahill, 1987). A porção oclusal do folículo dentário é considerada responsável pela osteoclastogênese nesta região da cripta e pela formação da via eruptiva. Estudos demonstraram a expressão de fatores como o RANKL, o CSF-1 MCP-1, EMAP-Il (endothelial monocyte activating polypeptide II). Estes fatores atuam no recrutamento de células precursoras de osteoclastos durante a movimentação eruptiva (Wise, 2009). Para que ocorra a fusão e ativação destas células em osteoclastos, é necessário o aumento da expressão de CSF-1 e RANKL, e a diminuição da expressão de OPG (Wise et al., 2000). No presente estudo, observamos a ausência de expressão da proteína RANKL no osso alveolar da porção oclusal da cripta nos animais tratados com alendronato, o que justifica o reduzido número de osteoclastos ativados e corrobora com os resultados descritos na literatura. Esta diminuição pode estar relacionada a danos ocorridos no folículo dentário subjacente devido ao contato das 
trabéculas ósseas. Entretanto, o recrutamento e fusão destas células ocorreram apesar da diminuição da expressão de RANKL, provavelmente devido à expressão dos demais fatores quimiotáticos como o CSF-1 não ter sido reduzida pelo alendronato. A expressão de OPG e RANK foi semelhante entre os grupos controle e tratado com alendronato.

Diversos estudos que atribuem o efeito de bisfosfonatos a alterações no mecanismo controlador da formação e ativação de osteoclastos por RANK/RANKL/OPG. O alendronato aumenta a expressão de RANKL em osteoblastos humanos estimulados com vitamina D (Enjuanes et al., 2009). A expressão de OPG e RANKL é elevada na doença de Paget, patologia caracterizada pelo aumento da reabsoção óssea por osteoclastos. O tratamento de pacientes com pamidronato diminui os níveis séricos de RANKL em indivíduos portadores desta doença (Martini et al., 2007). A análise de osteoclastos obtidos da medula óssea de seres humanos que utilizam alendronato in vitro demonstra diminuição da osteoclastogênese e da expressão de RANKL pelas células estromais (Eslami et al., 2011), o que reforça a hipótese levantada pelos resultados obtidos no presente estudo. Além da expressão dos fatores provenientes do folículo dentário ter sido provavelmente diminuída devido aos danos provocados pelo contato das trabéculas, o alendronato pode ter atuado diretamente sobre as células do folículo dentário, células mesenquimais e osteoblastos presentes na porção oclusal da cripta.

Além da reabsorção da porção oclusal da cripta óssea, alguns autores consideram a formação óssea na base do alvéolo, no septo alveolar e na crista alveolar e o rearranjo de fibras periodontais eventos indispensáveis no processo de erupção ativa, sendo estes mecanismos regulados por citocinas tais como membros da superfamília do TGF $\beta$ (Oikawa et al., 2011). Em ratos cujo gene correspondente à BMP-6 fora silenciado, os molares não erupcionam devido à redução do tecido ósseo formado no alvéolo, mesmo havendo a formação de via eruptiva (Wise et al., 2011). A formação óssea na cripta alveolar pode ser o mecanismo que promove a erupção de réplicas de coroas dentais implantadas no osso alveolar de cães em estudo realizado nos anos 80 (Marks e Cahill, 1984), e também da erupção de dentes sem raiz em macacos descritos nos anos 60 (Gowgiel, 1961). 
A alteração da remodelação óssea pelos bisfosfonatos, além de ter interferido na erupção dentária, ocasionou defeitos na superfície do esmalte dos molares. Nos espécimes tratados com etidronato, tais alterações foram decorrentes da indução de falhas na mineralização do esmalte em alguns pontos, efeito previamente descrito em estudos no esmalte de incisivos de ratos tratados (Weile et al., 1990). Nos animais tratados com alendronato, a análise dos molares de animais com 30 dias de idade revelou a presença de numerosas depressões na superfície do esmalte, criando um aspecto rugoso. Tal efeito foi ocasionado pelo crescimento da coroa no interior da cripta cuja reabsorção e remodelação das paredes não ocorreram adequadamente. Apesar da presença de deformidades no esmalte, o alendronato não causou hipoplasia deste tecido, o que foi demonstrado em estudo anterior (Massa et al., 2006).

Durante o processo eruptivo ocorre simultaneamente a formação radicular. Foi observada nos espécimes controles a presença de osteoclastos TRAP-positivos e remodelação óssea no osso alveolar da base da cripta. As imunomarcações com OPN e BSP nas linhas cimentantes de aposição e de reversão evidenciaram a intensa remodelação que ocorre no osso alveolar do periodonto em formação. Nos animais tratados com alendronato, como não houve reabsorção óssea acoplada à neoformação, a porção basal da cripta não se ajustou à anatomia do dente em formação e, consequentemente, ocorreu compressão do folículo dentário e anquilose. Com a compressão do folículo dentário e da bainha epitelial radicular, a formação radicular não ocorreu nos espécimes tratados com alendronato. Há estudos que demonstram que o folículo dentário apresenta alta expressão de BMP-2 na região basal da cripta (Wise e yao, 2006), e de TGF $\beta$-1 no osso alveolar e fibroblastos durante a formação radicular em ratos jovens (Oikawa et al., 2011). Foi também demonstrado que as células da bainha epitelial radicular respondem à sinalização por BMP, ativando a via BMP/TGF- $\beta$ (Aberg et al, 1997; Huang et al, 2010), a qual sinaliza, através da proteína Smad-4, a diferenciação de células mesenquimais da papila dentária em pré odontoblastos (Huang et al, 2010). Considerando-se as informações da literatura e observando a rotura ocasionada no folículo dentário e bainha epitelial radicular com o tratamento com alendronato, pode-se considerar que o folículo dentário possa desempenhar um papel chave nesse processo. O folículo seria responsável pela sinalização da proliferação apical 
de células epiteliais durante a rizogênese, e também indiretamente na indução da diferenciação de odontoblastos radiculares.

A partir dos resultados e das observações apontadas no presente estudo, pode-se considerar que a ativação e reabsorção óssea por osteoclastos são fundamentais para que ocorra o processo eruptivo, assim como afirmado por diversos autores (Wise e King, 2008; Wise, 2009). A interrupção da reabsorção óssea na parte oclusal da cripta provocada pelo alendronato, assim como a reabsorção mais lenta da mesma área provocada pelo etidronato demonstram a importância da reabsorção e formação da via eruptiva durante a erupção intraóssea.

Em relação aos efeitos do etidronato, pode-se afirmar que o desacoplamento entre formação e reabsorção óssea que ocorreu durante o processo eruptivo e de formação radicular acarretou no atraso dos mesmos. As anquiloses que ocorreram no grupo etidronato foram observadas apenas em fases mais avançadas em que a formação radicular já se iniciara. Pode-se inferir que este evento tenha "freado" o desenvolvimento radicular e, consequentemente, diminuído a "força" eruptiva.

O uso clínico de bisfosfonatos em pacientes jovens é empregado em diversas situações, como em casos de osteoporose primária e secundária, e osteogênese imperfeita (Maasalu et al., 2003; Castillo e Samson-Fang, 2009; Bachrach e Ward, 2009; Shaw et al., 2008). Entretanto, os efeitos secundários destes fármacos em outros órgãos ainda não são totalmente conhecidos, e o efeito inibitório sobre a formação e erupção dentária deve ser considerado. Clinicamente, tem sido relatado que crianças com osteogênese imperfeita tratadas com bisfosfonatos apresentaram atraso significativo do processo eruptivo (Kamoun-Goldrat et al., 2008).

A observação das alterações provocadas em nosso estudo contribui com a compreensão dos fenômenos que são necessários ao processo eruptivo, os quais são muito discutidos na literatura. Afirma-se que a formação dentária não depende exclusivamente da formação de via eruptiva, diante dos experimentos apresentados até o presente (Wise e King, 2008). Entretanto, observamos em nossos resultados que a formação dentária não ocorre adequadamente, principalmente a formação 
radicular, sem a presença de via eruptiva e remodelação da base da cripta. Além disso, os resultados obtidos com o tratamento com alendronato e etidronato demonstram que a formação radicular também representa um evento fundamental para a erupção dentária. 
7 CONCLUSÕES 
Os resultados do presente estudo permitem concluir que:

- O etidronato e o alendronato não inibiram a osteoclastogênese in vivo.

- O alendronato promoveu o aumento do número de osteoclastos no osso alveolar da maxila, e diminuiu o número de células ativadas devido à inibição da expressão da proteína RANKL no osso alveolar oclusal da cripta.

- O alendronato impediu a formação da via eruptiva, a erupção dentária e a formação radicular.

- O etidronato diminuiu o número de osteoclastos durante a fase intraóssea da erupção dentária, atrasou o processo de erupção e alterou o desenvolvimento da raiz e do periodonto. 


\section{REFERÊNCIAS*}

Al Deeb SK, Hamdan II, AI Najjar SM. Spectroscopic and HPLC methods for the determination of alendronate in tablets and urine. Talanta 2004;64:695-702.

Alatli I, Hammarström L. Root surface defects in rat molar induced by 1hydroxyethylidene-1,1-bisphosphonate. Acta Odontol Scad. 1996;54:59-65.

Alatli I, Li J, Hammarström L. Ultimate tensile strength of PDL of molars in rats after 1-hydroxyethylidene-1,1-bisphosphonate injections. J Dent. 1997;25:313-9.

Arai $N$, Ohya K, Kasugai S, Shimokawa H, Ohida S, Ogura H, Amagasa T. Expression of bone sialoprotein mRNA during bone formation and resorption induced by colchicine in rat tibial bone marrow cavity. J Bone Miner Res. 1995;10:1209-17.

Arana-Chavez VE, Andia-Merlin RY. Scanning electron microscopy examination of resorbing enamel surfaces in unexfoliated primary molar teeth. J Dent Child. 1998;65:182-5.

Arana-Chavez VE, Bradaschia-Correa V. Clastic cells: mineralized tissue resorption in health and disease. Int J Biochem Cell Biol. 2009;41:446-50.

Arana-Chavez VE, Nanci A. High-resolution immunocytochemistry of noncollagenous matrix proteins in rat mandibles processed with microwave irradiation. J Histeochem Cytochem. 2001;49:1099-109.

*De acordo com:

INTERNATIONAL COMMITTEE OF MEDICAL JOURNAL EDITORS. Uniform requirements for manuscripts submitted to biomedical journals. Available from: http://www.nlm.nih.gov/bsd/uniform_requirements.html [2007 May 22]. 
Beertsen W, Niehof A, Everts V. Effects of 1-hydroxyethylidene-1, 1-bisphosphonate (HEBP) on the formation of dentin and the periodontal attachment apparatus in the mouse. Am J Anat. 1985;174:83-103.

Bianco P, Fisher LW, Young MF, Termine JD, Robey PG. Expression of bone sialoprotein (BSP) in developing human tissues. Calcif Tissue Int. 1991;49:421-6.

Bonewald LF. The amazing osteocyte. J Bone Miner Res. 2011;26:229-38.

Brandsten C, Alatli I, Wurtz T, Hammarstrom L. Coronal dentinal nodules induced by single or multiple injections of HEBP in young rats. Connect Tissue Res. 1995;32:275-9.

Bachrach L, Ward L. Bisphosphonate use in childhood osteoporosis. J Clin Endocrinol Metab. 2009;94:400-9.Cahill DR, Marks SC. Tooth eruption: evidence for the central role of the dental follicle. J Oral Pathol Med. 1980;9:189-200.

Camilleri S, McDonald F. Runx2 and dental development. Eur J Oral Sci. 2006;114:361-73.

Castillo H, Samson-Fang L. Effects of bisphosphonates in children with osteogenesis imperfecta: an AACPDM systematic review. Dev Med Child Neurol. 2009;51:17-29.

Chellaiah MA, Kizer N, Biswas R, Alvarez U, Strauss-Schoenberger J, Rifas L, et al. Osteopontin deficiency produces osteoclast dysfunction due to reduced CD44 surface expression. Mol Biol Cell. 2003;14:173-89.

Chen S, Gluhak-Heinrich J, Wang YH, Wu YM, Chuang HH, Chen L et al. Runx2, Osx and Dspp in tooth development. J Dent Res. 2009;88:904-9.

Coxon FP, Thompson K, Rogers MJ. Recent advances in understanding the mechanism of action of bisphosphonates. Curr Opin Pharmacol. 2006;6:307-12. 
Enjuanes A, Ruiz-Gaspà S, Peris $P$, Ozalla D, Álvarez L, Combalia A, et al. The effect of the alendronate on OPG/RANKL system in differentiated primary human osteoblasts. Endocr. 2010;37:180-6.

Eslami B, Zhou S, Eekeren IV, LeBoff MS, Glowacki J. Reduced osteoclastogenesis and RANKL expression in marrow from women taking alendronate. Calcif Tissue Res. 2011;88:272-80.

Fejerskov $\mathrm{O}$, Josephsen $\mathrm{K}$, Weile $\mathrm{V}$. The effect of a single dose of 1hydroxyethylidene-1,1-bisphosphonate (HEBP) on secretory ameloblasts and enamel formation in rat incisors. J Biol Buccale. 1990;18:339-54.

Fisher LW, Mcbride OW, Termine JD, Young MF. Human bone sialoprotein. Deduced protein sequence and chromosomal localization. J Biol Chem. 1990;265:2347-51.

Franz-Odendaal TA, Hall BK, Witten PE. Buried alive: how osteoblasts become osteocytes. Develop Dynam. 2006;235:176-90.

Frazen A., Heinegard D. Isolation and characterization of two sialoproteins present only in bone calcified matrix. Biochem J. 1985;232:715-24.

Fungtharnthip P, Yamada Y, Takagi Y, Ohya K. Autoradiographic investigation of 1hydroxyethylidene-1,1-bisphosphonate on matrix protein synthesis and secretion by secretory ameloblasts in rat incisors. Arch Oral Biol. 2000; 45:495-506.

Gowgiel JM. Eruption of irradiation-produced rootless teeth in monkeys. J Dent Res. 1961;40:538-47.

Grier RL, Wise GE. Inhibition of tooth eruption in the rat by a bisphosphonate. J Dent Res. 1998;77:8-15.

Halasy-Nagy JM, Rodan GA, Reszka AA. Inhibition of bone resorption by alendronate and risedronate does not require osteoclast apoptosis. Bone 2001;29:553-9. 
Hirashita A. The aspect of ultrastructural changes of the osteoblasts and surface areas of alveolar bone appearing in experimental tooth movement. Bull Tokyo Med Univ. 1976; 23:245-60.

Holliday LS, Lu M, Lee BS, Nelson RD, Solivan S, Zhang L, et al. The amino-terminal domain of the $B$ subunit of vacuolar H+-ATPase contains a filamentous actin binding site. J Biol Chem. 2000;275:32331-7.

Huang X, Xu X, Bringas Jr P, Hung YP, Chai Y. Smad-4-Shh-Nfic signaling cascademediated epithelial-mesenchymal interaction is crucial in regulating tooth root development. J Bone Min Res. 2010;25:1167-78.

Hurst IR, Zuo J, Jiang J, Holliday LS. Actin-related protein 2/3 complex is required for actin ring formation. J Bone Miner Res. 2004;19:499-506.

Itzstein C, Coxon FP, Rogers MJ. The regulation of osteoclast function and bone resorption by small GTPases. Small GTPases 2011;2:117-30.

Janones DS, Massa LF, Arana-Chavez VE. Immunocytochemical examination of the presence of amelogenin during the root development of rat molars. Arch Oral Biol. 2005;50:527-32.

Josephsen K, Fejerskov O, Baelum V, Weile V. The effect of a single dose of 1 hydroxyethylidene-1,1-bisphosphonate (HEBP) on presecretory ameloblast differentiation in rat incisors. J Biol Buccale. 1990;18:321-37.

Jurdic P, Saltel F, Chabadel A, Destaing O. Podosome and sealing zone: specificity of the osteoclast model. Eur J Cell Biol. 2006;85:195-202.

Kamoun-Goldrat A, Ginisty D, Le Merrer M. Effects of bisphosphonates on tooth eruption in children with osteogenesis imperfecta. Eur J Oral Sci. 2008; 116:195-98.

Karsdal MA, Martin TJ, Bollerslev J, Christiansen C, Henriksen K. Are nonresorbing osteoclasts sources of bone anabolic activity? J Bone Miner Res. 2007;22:487-94. 
Katchburian E, Arana-Chavez VE. Histologia e embriologia oral: texto-atlascorrelações clínicas. 2. ed. Buenos Aires: Médica Panamericana; 2004. 372 p.

Kawakami M, Kuroda S, Yamashita K, Yoshida Ca, Nakagawa K, Takada K. Expression of CSF-1 receptor on TRAP-positive multinuclear cells around the erupting molars in rats. J Craniofac Gen Dev Biol 1999;19:213-20.

Li Y, Nakayama H, Notani T, Ahmad M, Tabata MJ, Takano Y. Phosphatase actioons at the site of appositional mineralization in bisphosphonate-affected bones of the rat. J Med Dent Sci. 2008;55:255-65.

Lerner UH. Osteoclast formation and resorption. Matrix Biol. 2000;19:107-20.

Liu D, Yao S, Pan F, Wise GE. Chronology and regulation of gene expression of RANKL in the rat dental follicle. Eur J Oral Sci. 2005;113:404-9.

Maasalu K, Haviko T, Martson A. Treatment of children with osteogenesis imperfecta in Estonia. Acta Paediatr 2003;92:452-55.

Marks SC, Cahill DR. Experimental study in the dog of the non-active role of the tooth in the eruptive process. Arch Oral Biol. 1984;29:311-22.

Marks SC Jr, Cahill DR. Regional control by the dental follicle of alterations in alveolar bone metabolism during tooth eruption. J Oral Pathol. 1987;16:164-9.

Marks SC Jr, Schroeder HE. Tooth eruption: theories and facts. Anat Rec. 1996;245:374-93.

Martini G, Gennari L, Merlotti D, Salvadori S, Franci MB, Campagna S, et al. Serum OPG and RANKL levels before and after intravenous bisphosphonate treatment in Paget's disease of bone. Bone 2007;40:457-63. 
Massa LF, Arana-Chavez VE. Ultrastructural preservation of rat embryonic dental tissues after rapid fization and dehydration under microwave irradiation. Eur $\mathrm{J}$ Oral Sci. 2000;108:74-7.

Massa LF, Bradaschia-Correa V, Arana-Chavez VE. Immunocytochemical study of amelogenin deposition during the early odontogenesis of molars in alendronatetreated newborn rats. J Histochem Cytochem. 2006;54:713-25.

McKee MD, Nanci A. Post-embedding colloidal-gold immunocytochemstry of noncollagenous extracellular matrix proteins in mineralized tissues. Microsc Res Tech. 1995;31:44-62.

McKee MD, Nanci A. Osteopontin at mineralized tissue interfaces in bone, teeth and osseointegrated implants: ultrastructural distribution and implications for mineralized tissue formation, turnover and repair. Microsc Res Tech. 1996;33:141-64.

McMichael BK, Kotadiya P, Singh T, Holliday LS, Lee BS. Tropomyosin isoforms localize to distinct microfilament populations in osteoclasts. Bone. 2006;39:694-705.

Nanci A. Content and distribution of noncollagenous matrix proteins in bone and cementum: relationship to speed of formation and collagen packing density. J Struct Biol. 1999;126:256-69.

Oikawa T, Nomura Y, Arai C, Noda K, Hanada N, Nakamura Y. Mechanism of active eruption of molars in adolescent rats. Eur J Orthod. 2011;33:221-7.

Ory S, Brazier H, Pawlak G, Blangy A. Rho GTPases in osteoclasts: orchestrators of podosome arrangement. Eur J Cell Biol. 2008;87:469-77.

Prince CW, Oosawa T, Butler WT, Tomana M, Bhown AS, Bhown M, et al. Isolation, characterization and biosynthesis of a phosphorylated glycoprotein from rat bone. J.Biol Chem. 1987;262:2900-6. 
Reinholt FP, Hultemby K, Oldberg A, Heinegard D. Osteopontin - a possible anchor of osteoclasts to bone. Proc Natl Acad Sci USA. 1990;87:4473-5.

Rogers MJ, Gordon S, Benford HL, Coxon FP, Luckman SP, Monkkonen J, et al. Cellular and molecular mechanisms of action of bisphosphonates. Cancer 2000;88:2961-78.

Ruch JV, Lesot H, Begue-Kirn C. Odontoblast differentiation. Int J Dev Biol. 1995;39:51-68.

Ruggiero SL, Dodson TB, Assael LA, Landesberg R, Marx RE, Mehrotra B. Task force on bisphosphonate-related osteonecrosis of the jaws. American Association of Oral and Maxillofacial Surgeons. American Association of Oral and Maxillofacial Surgeons position paper on bisphosphonate-related osteonecrosis of the jaw - 2009 update. Aust Endod J. 2009;35:119-30.

Russell RGG. Bisphosphonates from bench to bedside. Ann N Y Acad Sci. 2006;1068:367-401.

Russell RGG, Croucher PI, Rogers MJ. Bisphosphonates: pharmacology, mechanisms of action and clinical uses. Osteoporos Int. 1999;2:S66-S80.

Russell RG, Watts NB, Ebetino FH, Rogers MJ. Mechanisms of action of bisphosphonates: similarities and differences and their potential influence on clinical efficacy. Osteoporos Int. 2008;19:733-59.

Sakai H, Takano Y, Ohya K, Kurosaki N. Intermitent inhibition of dentin mineralization of rat incisors under continual infusion of 1-hydroxyethylidene-1,1-bisphosphonate (HEBP) using a subcutaneous mini osmotic pump. Arch Histol Cytol. 1999;62:171-9.

Sato M, Grasser W, Endo N, Akins R, Simmons H, Thompson DD, et al. Bisphosphonate action - alendronate localization in rat bone and effects on osteoclast ultrastructure. J Clin Invest. 1991;88:2095-105. 
Shaw NJ. Management of osteoporosis in children. Eur J Endocrinol. 2009;159:S33S9.

Slavkin HC, BringasJr Epithelial-mesenchyme interactions during odontogenesis. Develop Biol. 1976;50:428-42.

Sodek J, Ganss B, McKee MD. Osteopontin. Crit Rev Oral Biol Med. 2000;11:279303.

Soltanoff CS, Chen W, Yang S, Li YP. Signaling networks that control the lineage commitment and differentiation of bone cells. Crit Rev Eukar Gene Exp. 2009;19:146.

Takano Y, Sakai H, Baba O, Sakamoto Y, Terashima T, Ohya K, et al. Demonstration of putative Ca-binding domains in dentin matrix of rat incisors after daily injections of 1-hydroxyethylidene-1,1-bisphosphonate (HEBP). Eur J Oral Sci. 1998;106:274-81.

Taylor A, Mules EH, Seabra MC, Helfrich MH, Rogers MJ. Coxon FP. Impaired prenylation of Rab GTPases in the gunmental mouse causes defects in bone cell function. Small GTPases. 2011;2:131-42.

Thesleff I. Epithelial-mesenchymal signaling regulating tooth morphogenesis. J Cell Sci. 2003;116:1647-8.

Tomazela-Herndl SA, Arana-Chavez VE. Ultrastructure of early mineral deposition during hyaline layer formation in rat molars. Arch Oral Biol. 2001;46:305-11.

Tomazela-Herndl SA, Arana-Chavez VE. Localisation of sulphated glycoconjugates during hyaline layer formation in rat molars by ultrastructural cytochemistry. $\mathrm{J}$ Mol Histol. 2004;35:63-8.

Van Beek ER, Lowik CWGM, Papapoulos SE. Bisphosphonates suppress bone resorption by a direct effect on early osteoclast precursors without affecting the 
osteoclastogenic capacity of cells: the role og protein geranylgeranylation in the action of nitrogen-containing bisphosphonates on osteoclast precursors. Bone. 2002;30:64-70.

Vasikaran SD. Bisphosphonates: an overview with special reference to alendronate. Ann Clin Biochem. 2001;38:608-23.

Vitté C, Fleisch H, Guenther HL. Bisphosphonates induce osteoblasts to secrete an inhibitor of osteoclast-mediated resorption. Endocrinology 1996;137:2324-33.

Warshawsky H, Moore G. A technique for the fixation and decalcification of rat incisors for electron microscopy. J Histochem Cytochem. 1967;15:542-9.

Weile V, Josephsen K, Fejerskov O. Effects of single doses of 1-hydroxyethylidene1,1-bisphosphonate on the mineralizing front of rat incisor enamel: a microradiographic and scanning electron microscopy study. Arch Oral Biol. 1990;11:857-67.

Weile V, Josephsen K, Fejerskov O. Scanning electron microscopy of final enamel formation in rat mandibular incisors following single injections of 1-hydroxyethylidene1,1-bisphosphonate. Calcif Tissue Int. 1993;52:318-24.

Wise GE, Fan W. Changes in the tartrate-resistant acid phosphatase cell population in dental follicles and bony crypts of rat molars during tooth eruption. J Dent Res. 1988;68:150-6.

Wise GE, Frazier-Bowers S, D'Souza RN. Cellular, molecular and genetic determinants of tooth eruption. Crit Rev Oral Biol Med. 2002;13:323-34.

Wise GE, He H, Gutierrez DL, Ring S, Yao S. Requirement of alveolar bone formation for eruption of rat molars. Eur J Oral Sci. 2011;119:333-8.

Wise, GE, King GJ. Mechanisms of tooth eruption and orthodontic tooth movement. J Dent Res. 2008;87:414-34. 
Wise GE, Lin F. The molecular biology of initiation of tooth eruption. J Dent Res. 1995;74:303-6.

Wise GE, Lin F, Zhao L. Immunolocalization of interleukin-1a in rat mandibular molar and its enhancement after in vivo injection of epidermal growth factor. Cell Tissue Res. 1995;280:21-6.

Wise, GE, Lumpkin SJ, Huang H, Zhang Q. Osteoprotegerin and osteoclast differentiation factor in tooth eruption. J Dent Res. 2000;79:1937-42.

Wise GE, Ren Y, Yao S. Regulation of osteoprotegerin gene expression in dental follicle cells. J Dent Res. 2003;82:298-302.

Wise GE, Yao S. Regional differences of expression of bone morphogenetic protein2 and RANKL in the rat dental follicle. Eur J Oral Sci. 2006;114: 512-6.

Wise GE, Yao S, Odgren PR, Pan F. CSF-1 regulation of osteoclastogenesis for tooth eruption. J Dent Res. 2005;84:837-41.

Xu X, Han J, Ito Y, Bringas $\mathrm{P}$, Jr, Urata MM, Chai Y. Cell autonomous requirement for Tgfbr2 in the disappearance of medial edge epithelium during palatal fusion. Dev Biol. 2006;297:238-48.

Yao S, Ring S, Henk WG, Wise GE. In vivo expression of RANKL in the rat dental follicle as determined by laser capture microdissection. Arch Oral Biol. 2004;49:4516.

Yao S, Wise GE. Protein kinase A expression and its possible roles in regulating tooth eruption genes in the dental follicle. Med Sci Monit. 2003;9:200-7.

Young MF, Kerr JM, Ibaraki K, Heegard AM, Robey PG. Structure, expression and regulation of the major noncollagenous matrix proteins of bone. Clin Orthop Relat Res. 1991;281:275-94. 
Zeichner-David M. Regeneration of periodontal tissues: cementogenesis revisited. Periodontology 2000;41:196-217.

Zuo J, Jiang J, Chen SH, Vergara S, Gong Y, et al. Actin binding activity of subunit b of vacuolar $\mathrm{H}_{+}$-ATPase is involved in its targeting to ruffled membranes of osteoclasts. J Bone Miner Res. 2006;21:714-21. 


\section{ANEXO 1}




\title{
Effects of alendronate on tooth eruption and molar root formation in young growing rats
}

\author{
Vivian Bradaschia-Correa • Luciana F. Massa • \\ Victor E. Arana-Chavez
}

Received: 12 July 2007 / Accepted: 28 August 2007 / Published online: 28 September 2007

(C) Springer-Verlag 2007

\begin{abstract}
Tooth eruption consists of the movement of teeth from the bony crypt in which they initiate their development to the occlusal plane in the oral cavity. Interactions between the tooth germ and its surrounding alveolar bone occur in order to offer spatial conditions for its development and eruption. This involves bone remodeling during which resoption is a key event. Bisphosphonates are a group of drugs that interfere with the resorption of mineralized tissues. With the purpose of investigating the effects of sodium alendronate (a potent bisphosphonate inhibitor of osteoclast activity) on alveolar bone during tooth development and eruption, we gave newborn rats daily doses of this drug for 4, 14, and 30 days. Samples of the maxillary alveolar process containing the tooth germs were processed for light, transmission, and scanning electron microscopy and were also submitted to tartrateresistant acid phosphatase histochemistry and high-resolution colloidal-gold immunolabeling for osteopontin. Inhibition of osteoclast activity by sodium alendronate caused the absence of tooth eruption. The lack of alveolar bone remodeling resulted in primary bone with the presence of latent osteoclasts and abundant osteopontin at the interfibrillar regions. The developing bone trabeculae invaded the dental follicle and reached the molar tooth germs, provoking deformities in enamel surfaces. No root formation was observed. These findings suggested that alendronate effec-
\end{abstract}

This work was supported by grants from Fapesp (04/05831-9 and 06/60094-5) and CNPq (Brazil).

V. Bradaschia-Correa L. F. Massa • V. E. Arana-Chavez $(\triangle)$ Laboratory of Mineralized Tissue Biology, Department of Cell and Developmental Biology, Institute of Biomedical Sciences, University of São Paulo,

05508-900 São Paulo, S.P., Brazil

e-mail: vearana@usp.br tively inhibited tooth eruption by interfering with the activation of osteoclasts, which remained in a latent stage.

Keywords Alveolar bone - Tooth eruption .

Bisphosphonates - Alendronate - Odontogenesis .

Rat (Wistar, albino)

\section{Introduction}

Tooth eruption is a developmental process by which teeth move from their bony crypt in which they begin their formation to their final position in the oral cavity. Tooth eruption is divided into five stages: pre-eruptive movements, intra-osseous eruption, mucosal penetration, preocclusal eruption, and post-occlusal eruption (Marks and Schroeder 1996). Bone resorption is necessary for the intraosseous stage of tooth eruption and for providing the space for the growing teeth in each bony crypt and in the alveolar process as a whole. During the intra-osseous stage, after the crown is completely formed, the inner and outer epithelia of the enamel organ proliferate in an apical direction in order to establish the epithelial diaphragm and Hertwig's epithelial root sheath. At this stage, discreet areas of resorption and formation are present at the basal portion of the bony crypt, while osteoclasts rise under the gubernacular canal to resorb the bone trabeculae at the occlusal portion of the bony crypt in order to establish the eruption pathway. Although numerous theories have been proposed to explain the exact mechanisms govern tooth eruption, none of them is able to explain the way in which it begins or is maintained. Indeed, despite numerous studies (for a review, see Wise et al. 2002), some aspects remain unclear. Independently of the mechanism(s) governing the eruption process, bone remodeling, especially bone resorption, 
is a necessary condition for teeth moving through the alveolar bone.

Alveolar bone is initially formed as a primary bone that is gradually substituted by secondary bone as remodeling occurs. In addition to collagen fibrils, alveolar bone matrix contains a variety of noncollagenous proteins, which are more abundant in the wide interfibrilar regions of primary bone than in the secondary bone in which collagen fibrils are more densely packed (Nanci 1999). One of the proteins prominently found in the noncollagenous matrix in bone is osteopontin (OPN), a multifunctional phosphorylated glycoprotein that presents certain molecular domains that allow binding to both cells and matrix. In mineralized bone matrix, OPN is found in cement lines, laminae limitantes, and at some small spaces among mineralized collagen fibrils. It is thought to participate in the adhesion of the osteoclast clear zone to bone matrix as a sealing agent (McKee and Nanci 1996).

Bisphosphonates are a class of drug analogs of pyrophosphate with high affinity to hydroxyapatite. They have the ability to inhibit osteoclast-mediated bone resorption and are widely used in prevention and treatment of osteoporosis and other bone disorders. The nitrogencontaining bisphosphonates cause toxic effects on osteoclasts, resulting in disorders in their cytoskeleton and intracellular signaling, the inhibition of adhesion mechanisms, structural changes in the ruffle border, and a decrease of their acid production. As a result, osteoclasts may become latent or inactive and undergo apoptosis (Rogers et al. 2000; Vasikaran 2001) or only lose their resorptive ability (Halasy-Nagy et al. 2001).

As tooth eruption comprises both bone formation and resorption during all stages, it is a biological event that offers an excellent model for studying the possible effects of drugs that interfere with bone metabolism. In the only study of the effects of bisphosphonates on tooth eruption, an average of 8 days delay in the eruption of molar teeth has been observed in pamidronate-treated rats (Grier and Wise 1998). Sodium alendronate is currently one of the bisphosphonate of choice in the treatment of bone diseases such as osteoporosis, as it has been shown to possess a higher anti-resorptive potency than that of pamidronate or risedronate (van Beek et al. 2003). It is also used for treatment of bone disorders in children (Srivastava and Alon 2003), despite its possible interference in both bone and tooth development. Indeed, little is known about these putative side-effects of bisphosphonates during skeletal development and growth.

We used an experimental model in which a single dose $(2.5 \mathrm{mg} / \mathrm{kg} / \mathrm{day})$ of sodium alendronate was administered daily to newborn rats (Massa et al. 2006) from the day of birth until ages of up to 30 days. The aim was to observe the effects of this bisphosphonate on the development of molar teeth from the stages of root formation and eruption until the period in which the teeth should have reached the functional occlusal plane and their relationship with their surrounding bony crypt. In addition, the presence of osteoclasts in the alveolar bone and their ultrastructural characteristics were examined. A high-resolution immunocytochemical approach was also carried out for examining the presence and distribution of OPN in alveolar bone, in order to establish whether it exhibited a primary (immature) or secondary (lamellar) appearance, and to verify whether this protein was present on the bone surfaces, since it might play a role in the adhesion of osteoclasts to mineralized matrix.

\section{Materials and methods}

Principles of laboratory animal care (NIH publication 85-23, 1985) and national laws on animal use were observed for the present study, which was authorized by the Ethical Committee for Animal Research of the University of São Paulo, Brazil.

\section{Sodium alendronate treatment}

Newborn Wistar albino rats $(n=72)$ were used, of which 48 were subjected to daily subcutaneous injections of $2.5 \mathrm{mg} / \mathrm{kg} /$ day sodium alendronate (Massa et al. 2006) from the day of birth to 4,14 , and 30 days of age. An additional 24 rats were injected daily with sterile saline solution during the same period. None of the alendronate-treated rats was weaned during the entire study in order that their nutrition was provided maternally. On the days cited, 16 alendronatetreated and eight control rats were anesthetized with $2 \%$ chlordrate 2-(6,6-xilidine)-5,6-dihydro-4-H-1,3-tiazine (Rompun) diluted 1:1 in ketamine (Francotar; $1 \mathrm{ml} / \mathrm{kg}$ body $\mathrm{wt}$ ) and decapitated. The maxillary alveolar processes and mandibles were dissected out and quickly fixed as follows.

\section{Macroscopical examination}

The oral cavity of all animals was examined during anaesthesia in order to check the eruption of teeth. Two additional animals of each group had their maxillary alveolar processes and the anterior region of their hemimandibles dissected out from the skull in order to examine the presence or absence of erupted teeth; these specimens were later discarded.

Hematoxylin-eosin staining

Alendronate-treated $(n=4)$ and control $(n=2)$ rats from each group had their maxillary alveolar processes fixed in 
Bouin's solution for $18 \mathrm{~h}$ at $4^{\circ} \mathrm{C}$. The processes were then rinsed in water, decalcified in $4.13 \%$ ethylenediaminetetraacetic acid (EDTA) for 20 days, dehydrated in graded concentrations of ethanol, and embedded in Paraplast by using the Microm HMP110 and AP280 apparatus. Thick sections $(5 \mu \mathrm{m})$ were obtained by using a Micron HM360 microtome and stained with hematoxylin and eosin. Coverslips were mounted with Entellan (Merck, Germany), and the slides examined in a Nikon Optiphot-2 light microscope.

\section{Tartrate-resistant acid phosphatase histochemistry}

The maxillary alveolar processes from four alendronatetreated and two control rats from each group were fixed in $0.1 \%$ glutaraldehyde and $4 \%$ formaldehyde buffered in $0.1 \mathrm{M}$ sodium cacodylate, $\mathrm{pH}$ 7.4. Specimens were immersed in a beaker containing $40 \mathrm{ml}$ fixative solution at room temperature, placed in a $20 \times 20 \mathrm{~cm}$ glass recipient filled with ice, and transferred to a Pelco 3440 laboratory microwave oven (Ted Pella, Redding, Calif., USA). The temperature probe of the oven was submerged into the fixative, and the specimens were then exposed to microwave irradiation at $100 \%$ setting for three cycles of $5 \mathrm{~min}$, with the temperature being programmed to a maximum of $37^{\circ} \mathrm{C}$. After microwave irradiation, specimens were transferred into fresh fixative solution in which they were left overnight at $4{ }^{\circ} \mathrm{C}$ (Massa and Arana-Chavez 2000). Decalcification was carried out as described above. The specimens were then dehydrated in graded ethanol concentrations and embedded in JB-4 historesin (Polysciences, Warrington, Pa., USA). Sections ( $3 \mu \mathrm{m}$ thick) were collected onto glass slides and submitted to tartrate-resistant acid phosphatase (TRAP) histochemistry. Briefly, Burstone complete medium was prepared by dissolving $4 \mathrm{mg}$ naphthol As-Bi phosphate substrate (Sigma, St. Louis, Mo., USA) in $0.25 \mathrm{ml}$ of N-N-
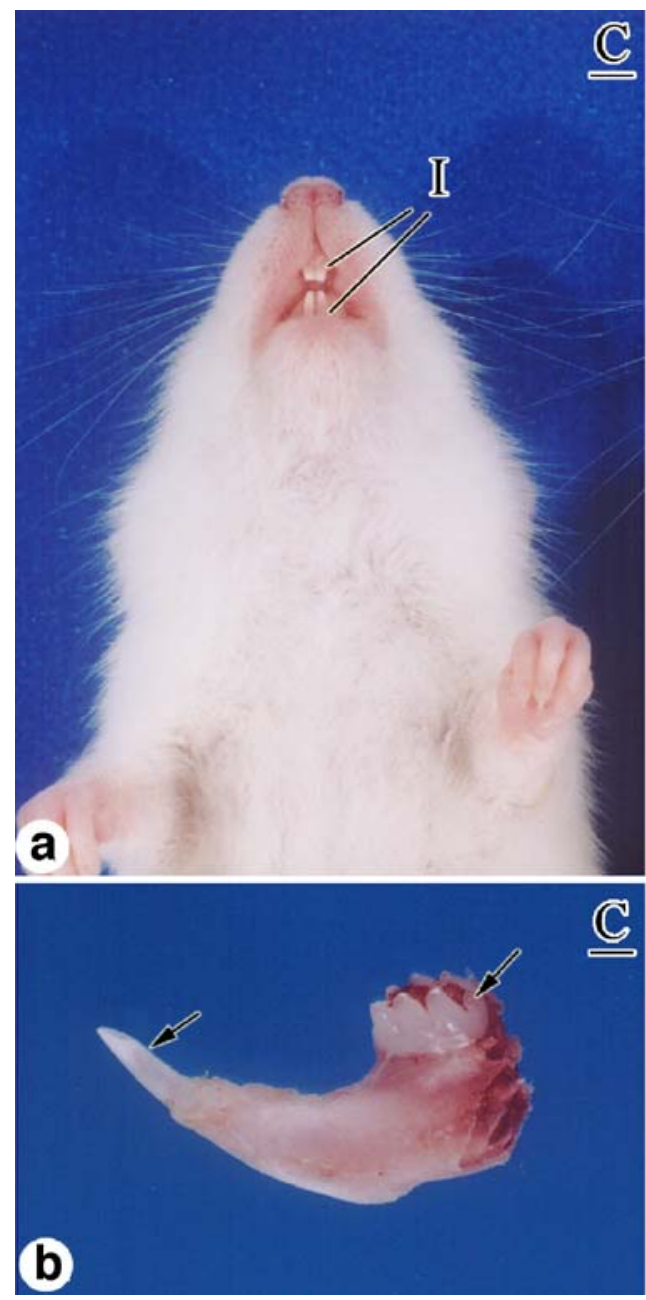

Fig. 1 Macroscopic appearance of incisors and first molar teeth in 30day-old rats. a Control rat $(C)$ with incisors $(I)$ fully erupted. b Anterior region of a dissected hemimandible from a control rat showing fully erupted incisor and first molar (arrows). c In contrast, the incisors were not erupted $(X)$ in the alendronate-treated rat $(A T)$. d

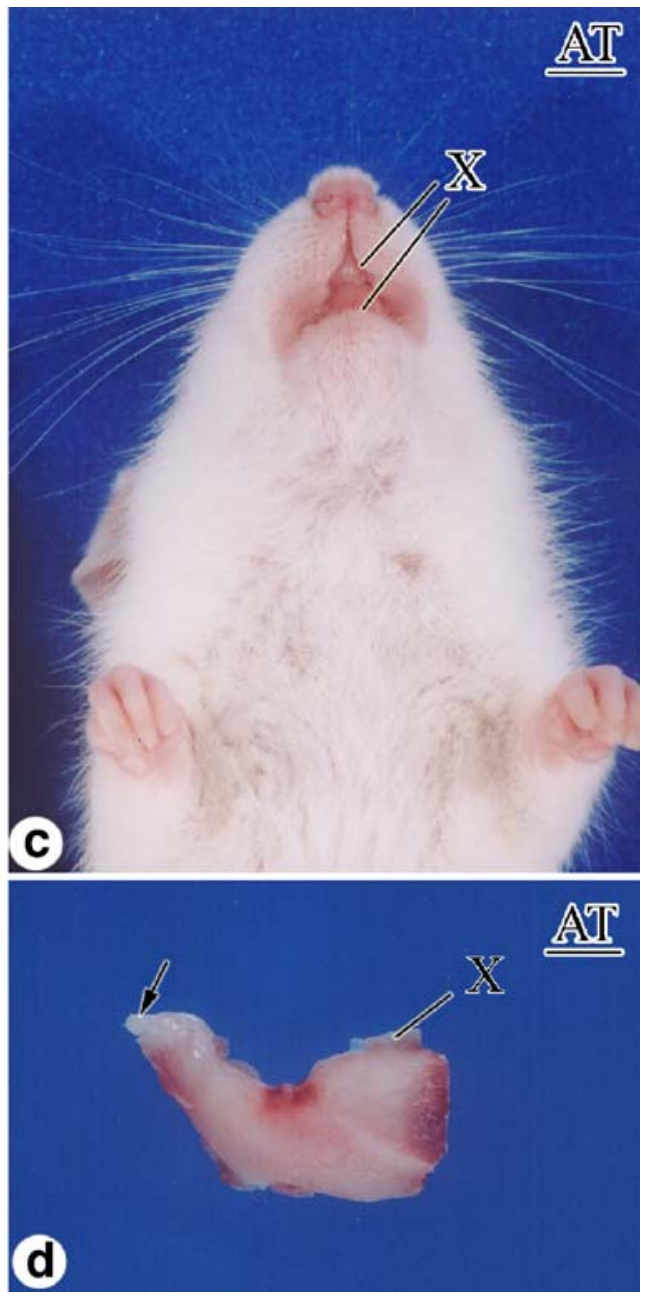

In the dissected hemimandible of the alendronate-treated rat, the cusp tip of the incisor could be observed (arrows) after the gum had been removed; there was no evidence of the intraosseous eruption of the first molar $(X)$ 

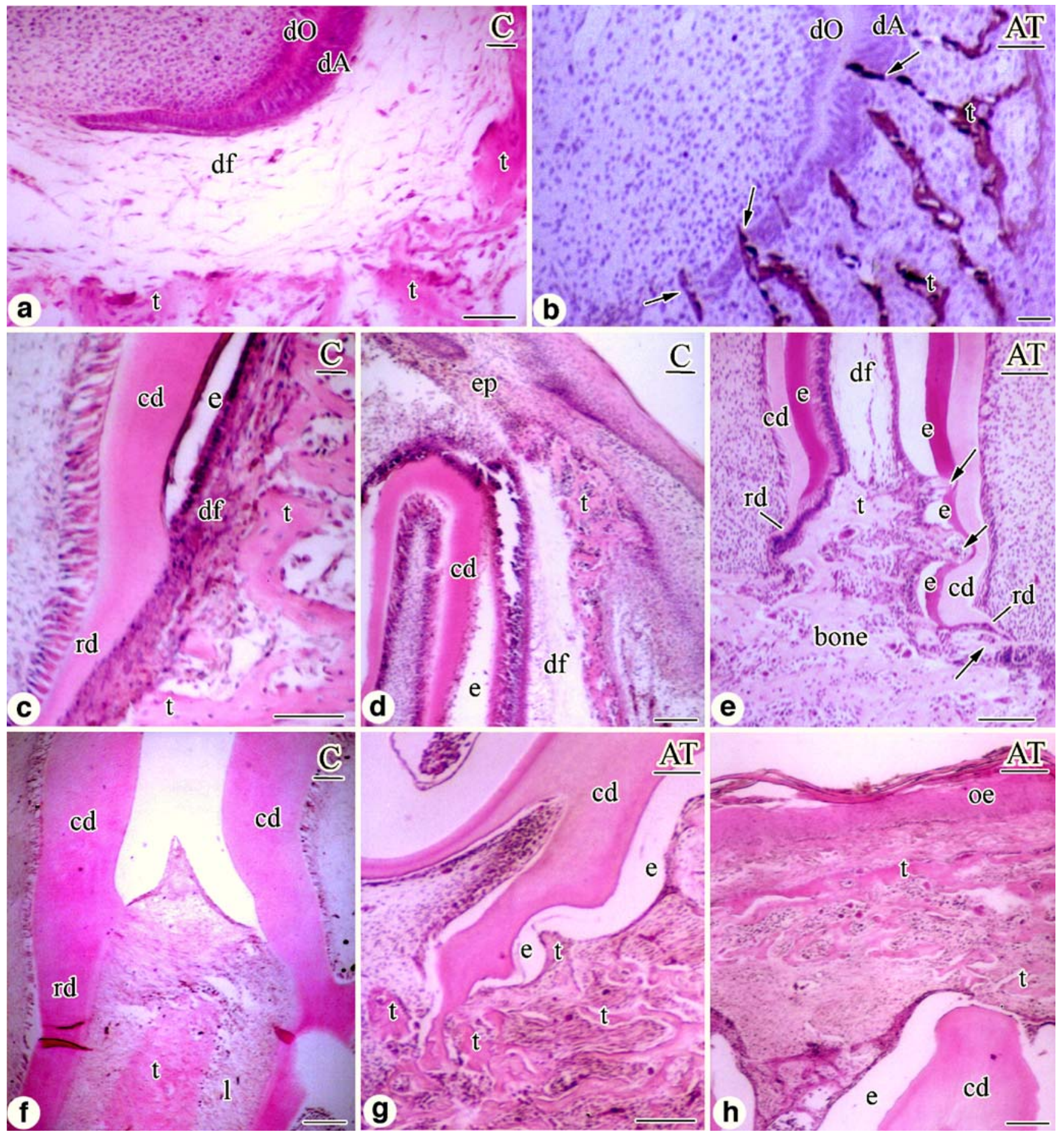

dimethylformamide, followed by the addition of $25 \mathrm{ml} 0.2 \mathrm{M}$ acetate buffer (pH 5.0), $35 \mathrm{mg}$ Fast Red Violet LB (coupling agent), and $60 \mu \mathrm{l} 10 \% \mathrm{MgCl}$. This medium was filtered, transferred $(25 \mathrm{ml})$ into a Coplin jar, and warmed to $37^{\circ} \mathrm{C}$, followed by the addition of $50 \mathrm{mM}$ D(-) tartaric acid. The slides containing the sections were incubated in this solution for $2 \mathrm{~h}$. Subsequently, the slides were washed in running water, dried at $25^{\circ} \mathrm{C}$, and then counterstained with Harris' hematoxylin for $10 \mathrm{~min}$. Coverslips were mounted with Entellan (Merck, Germany), and the slides examined with a Nikon Optiphot-2 light microscope (Bonafe-Oliveira et al. 2003).

Transmission electron microscopy

Upper alveolar processes from four alendronate-treated and two control rats from each group were fixed as described 
4 Fig. 2 Light micrographs of 4-, 14-, and 30-day-old rats, during tooth development. a Cervical loop region of a tooth germ at the bell stage, constituted by differentiating odontoblasts $(d O)$ and differentiating ameloblasts $(d A)$, from a 4-day-old control specimen. Note that the dental follicle $(d f)$ is interposed between the tooth germ and the bone trabeculae $(t)$ from the basis of the bony crypt. Bar $100 \mu \mathrm{m}$. b Same region of a tooth germ from a 4-day-old alendronate-treated specimen. The dental follicle appears discontinuous because it has been invaded by bone trabeculae $(t)$ that reach the enamel organ at some points (arrows). Bar $40 \mu \mathrm{m}$. c Molar germ from a 14-day-old control specimen in which the root dentine $(r d)$ is forming, with coronal dentine $(c d)$ at an advanced stage of development, whereas the enamel $(e)$ is at the maturation stage. Note that the dental follicle $(d f)$ is interposed between the tooth germ and the trabeculae $(t)$ of the bony crypt. Bar $50 \mu \mathrm{m}$. d Occlusal region of a developing molar tooth from a 14-day-old control specimen. Note that the eruption pathway (ep) has been formed by previous resorption of bone trabeculae $(t)$. Bar $100 \mu \mathrm{m}$. e Cervical region of the first (right) and second (left) developing molars from a 14-day-old alendronate-treated specimen. The coronal dentine $(c d)$ appears covered by the space that corresponds to the mature enamel $(e)$ in the first molar and by the maturing enamel $(e)$ in the second molar. Note that the dental follicle $(d f)$ surrounds the tooth germ at the coronal portion, whereas bone trabeculae have invaded it at the cervical region. The bone trabeculae have established contact (arrows) with the enamel and dentine from the first molar. Bar $100 \mu \mathrm{m}$. f Cervical region of the first (right) and second (left) fully erupted molars from a 30-day-old control specimen in which the coronal dentine $(c d)$ appears surrounded by a space that corresponds to decalcified enamel. A portion of the root of each molar is shown ( $t$ alveolar bone, $l$ periodontal ligament, $r d$ root dentine). Bar $100 \mu \mathrm{m}$. g Cervical region of a molar from a 30-day-old alendronatetreated specimen showing a similar aspect to that of the respective 14day-old specimens: bone trabeculae $(t)$ in contact with enamel $(e)$ and with the incipient root portion. Bar $100 \mu \mathrm{m}$. h Occlusal region of a molar from a 30-day-old alendronate-treated specimen. Note that the molar has not erupted because the trabeculae $(t)$ of the occlusal portion of bony crypt have not been resorbed (oe oral epithelium). Bar $100 \mu \mathrm{m}$

for histochemistry. They were then post-fixed in $0.1 \mathrm{M}$ cacodylate-buffered $1 \%$ osmium tetroxide for $2 \mathrm{~h}$ at room temperature, dehydrated in graded concentrations of alcohol, and embedded in LR White resin (London Resin, UK). Toluidine-blue-stained $1-\mu \mathrm{m}$-thick sections were examined in a light microscope, and cervical and occlusal regions of the tooth germ/alveolar bony crypt were selected for ultrathin sectioning. Ultrathin sections ( $80 \mathrm{~nm}$ thick) were obtained with a diamond knife on a Leica Ultracut $\mathrm{R}$ ultramicrotome (Leica, Buffalo, N.Y., USA), collected onto 200-mesh copper grids, stained with uranyl acetate and lead citrate, and examined in a Jeol 1010 transmission electron microscope operated at $80 \mathrm{kV}$.

Postembedding colloidal gold immunocytochemistry

Ultrathin sections were mounted onto nickel grids, incubated for $20 \mathrm{~min}$ on a drop of $0.01 \mathrm{M}$ phosphate-buffered saline (PBS) containing ovalbumin and then on a drop of chicken anti-rat OPN (Nanci et al. 1996) for $5 \mathrm{~h}$ at room temperature, followed by incubation in secondary antibody (rabbit anti-chicken $\operatorname{IgG}$ ) for $1 \mathrm{~h}$, a rinse with PBS, and incubation on PBS-ovalbumin for $20 \mathrm{~min}$. They were subsequently incubated for $30 \mathrm{~min}$ at room temperature with a protein A-gold complex. Negative controls for the specificity of labeling consisted of incubating the sections with the secondary antibody followed by protein A-gold or with protein A-gold alone. The tissue sections were rinsed thoroughly with PBS followed by distilled water and then air-dried (Arana-Chavez and Nanci 2001). Staining was carried out with uranyl acetate and lead citrate, and the sections were viewed in a JEOL 1010 transmission electron microscope operated at $80 \mathrm{kV}$.

\section{Scanning electron microscopy}

The first upper molars of four alendronate-treated and two control rats per age (14 and 30 days) were carefully dissected out and fixed in $0.1 \%$ glutaraldehyde and $4 \%$ formaldehyde in $0.1 \mathrm{M}$ sodium cacodylate buffer $(\mathrm{pH}$ 7.4) under microwave irradiation for $5 \mathrm{~min}$. The specimens were left in the fixative solution overnight at $4^{\circ} \mathrm{C}$. They were then treated with $2 \% \mathrm{NaOCl}$ solution for $3 \mathrm{~h}$ followed by 3 min under ultra-sound in order to leave only the mineralized tissues, washed in distilled water, dehydrated in graded concentrations of ethanol, treated with hexamethyldisilazane for $10 \mathrm{~min}$, and air-dried for $24 \mathrm{~h}$ at room temperature. Finally, the molars were mounted onto aluminum stubs and gold-coated in a Bal-Tec SCD 050 apparatus. The specimens were examined in a JEOL 6100 scanning electron microscope operated at $15 \mathrm{kV}$.

\section{Results}

\section{Macroscopic examination}

Although intraoral macroscopic examination was carried out at all the studied periods, photographic documentation was only recorded during the last period (30 days). Control rats at the age of 30 days showed the eruption of all their teeth (Fig. 1a), which were clearly seen when the hemimandibles were dissected out and the soft tissues removed (Fig. 1b). In contrast, alendronate-treated rats at the same age did not have erupted incisors (Fig. 1c). Examination of the dissected hemimandibles revealed the arrested eruption of the incisor whose cusp tip was just visible, whereas the cusps of the first molars could not be observed (Fig. 1d). 


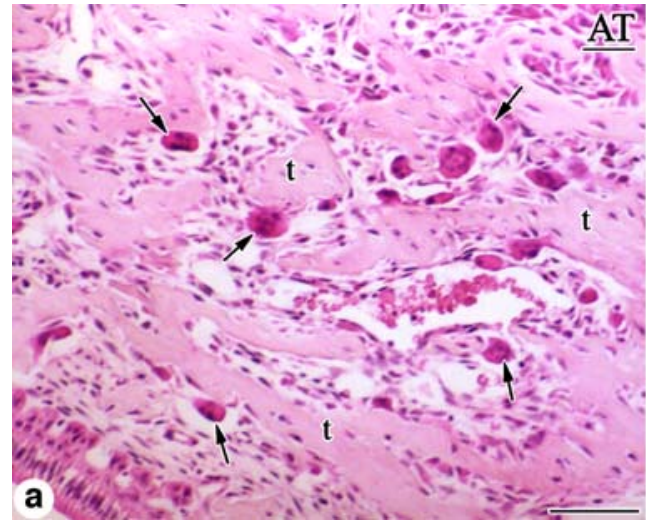

Fig. 3 Light micrographs showing two areas of the occlusal region of the bony crypt of 14-day-old alendronate-treated specimens in which several interconnected trabeculae $(t)$ are present. a Numerous round multinucleated osteoclasts (arrows) are found at the intertrabecular regions, most of them lying at a distance from trabeculae. Hematoxylin-

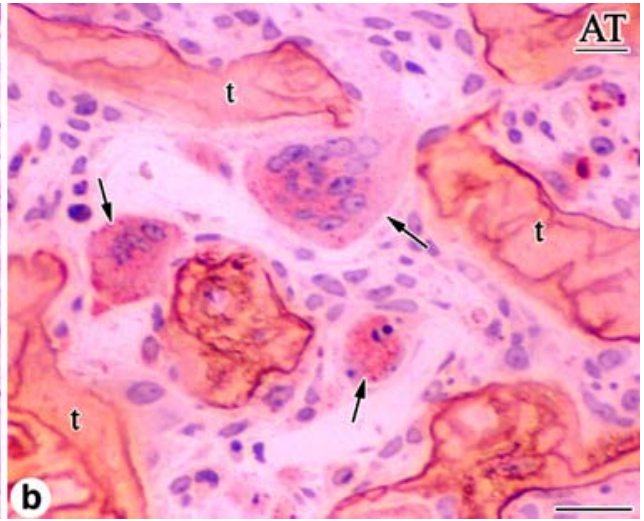

eosin staining. Bar $50 \mu \mathrm{m}$. b A similar area processed for tartrateresistant acid phosphatase (TRAP) histochemistry showing three TRAPpositive multinucleated round osteoclasts (arrows) between the bone trabeculae $(t)$. Hematoxylin counterstaining. Bar $20 \mu \mathrm{m}$
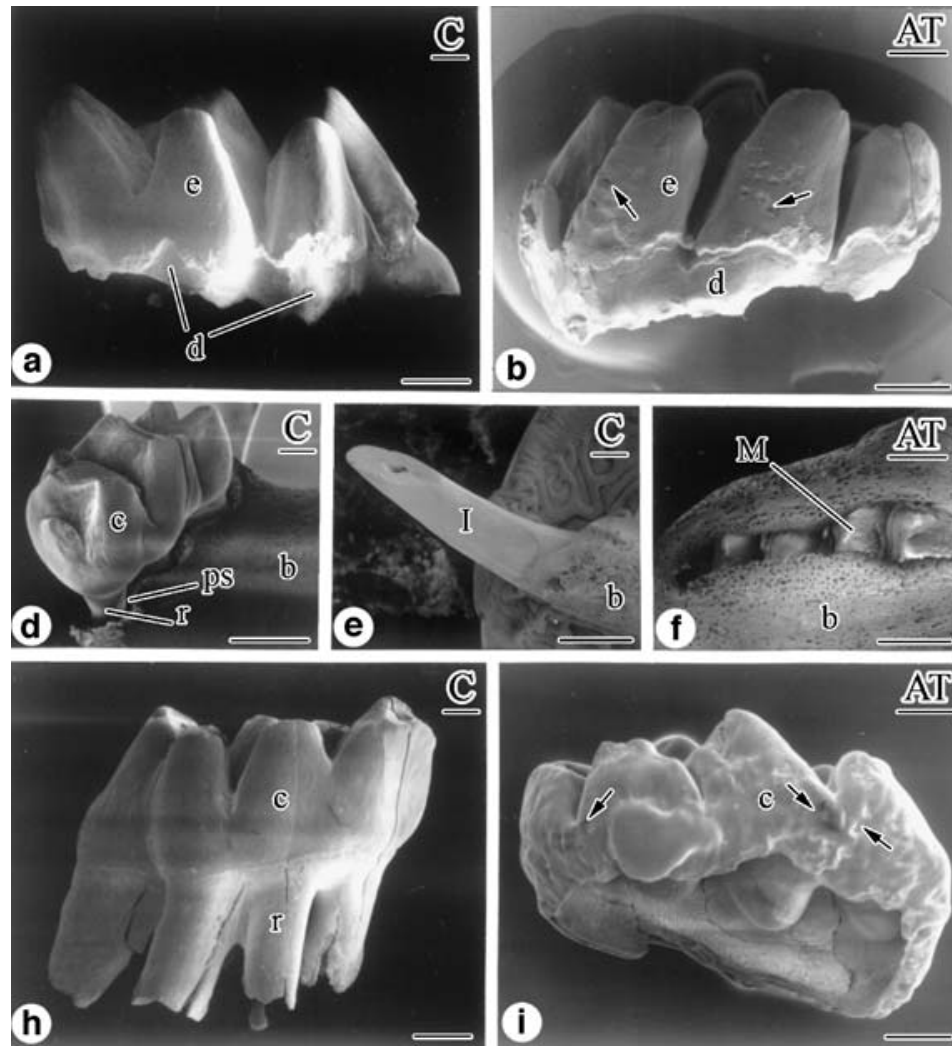

Fig. 4 Scanning electron micrographs showing molars and incisors from 14-day-old and 30-day-old rats. a Developing upper first molar from a 14-day-old specimen; note the middle and occlusal portions of smooth enamel surface $(e)$. The subjacent dentine $(d)$ is revealed at the cervical region after removal of the immature enamel matrix by processing. Bar $0.5 \mathrm{~mm}$. b Molar from an alendronate-treated 14-dayold rat; note the depressions (arrows) at the cusp slopes of the enamel surface (e). Bar $0.5 \mathrm{~mm}$. c Cervical alterations at higher magnification (arrows). Bar $100 \mu \mathrm{m}$. d Portion of the mandible from a control 30day-old rat in which the first molar appeared fully erupted $(c)$. Note the roots $(r)$ associated with the bone $(b)$ with the periodontal space (ps) between them. Bar $1 \mathrm{~mm}$. e Tip of a completely erupted lower incisor $(I)$ from another control 30-day-old rat ( $b$ bone). Bar $1 \mathrm{~mm}$. f An occlusal view of the mandible from an alendronate-treated 30-dayold rat. The occlusal portion of the bony crypt is incompletely
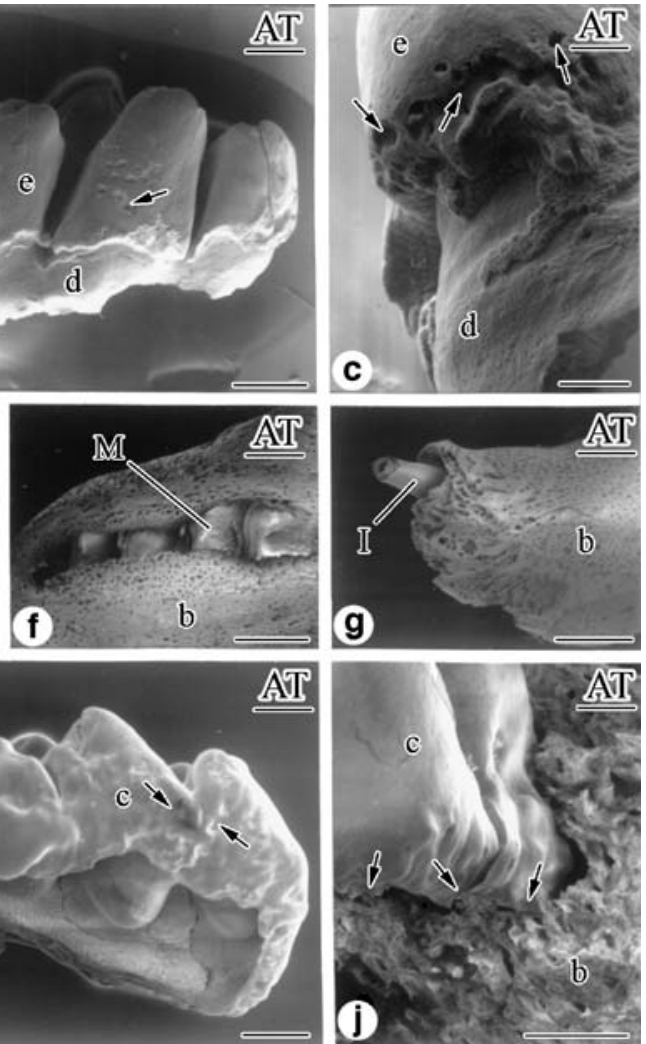

resorbed, and only the cusp tips of the first molar $(M)$ can be seen between the bone trabeculae $(b)$ of the alveolar process. Bar $1 \mathrm{~mm} . \mathbf{g}$ Anterior portion of the mandible from an alendronate-treated 30-dayold rat. Only the tip of the incisor $(I)$ can be seen surrounded by the mandibular bone $(b)$. Bar $1 \mathrm{~mm}$. h Dissected lower first molar exhibiting its crown $(c)$ with smooth enamel surface and its roots $(r)$ in an advanced stage of development, from a control 30-day-old rat. Bar $0.5 \mathrm{~mm}$. i Dissected lower first molar from an alendronate-treated 30day-old specimen in which only the crown $(c)$ has been formed. The enamel surface exhibits numerous depressions (arrows) at the cervical region. Bar $0.5 \mathrm{~mm}$. j Another first molar ( $c$ crown) from an alendronate-treated 30-day-old specimen has been partially dissected to show areas in which the bone trabeculae $(b)$ are in close association with the cervical portion of the molar, establishing areas of ankylosis (arrows). Bar $0.5 \mathrm{~mm}$ 


\section{Light microscopy}

In control rats at day 4, the first upper molar tooth germs were at the late bell stage of odontogenesis. The dental follicle surrounded the entire tooth germ separating it from the alveolar process of the bony crypt (Fig. 2a). In the alendronate-treated specimens, however, the dental follicle was not continuous. Some fine trabeculae arising from the lateral sides and from the basis of the bony crypt established contact with the enamel organ at several points, especially at the cervical loop (Fig. 2b).

In a later stage, at day 14, mineralization of crown tissues of the control specimens was almost complete, despite the cervical portion of the enamel still undergoing maturation, and root dentin formation was taking place (Fig. 2c). The bone in the occlusal portion of the crypt was being resorbed in order to establish the eruption pathway (Fig. 2d). Bone trabeculae surrounding the alendronatetreated tooth germ grew thickly and contacted structures of the dental follicle and tooth germ. The cervical loop/ Hertwig's epithelial root sheath was disorganized. The bone trabeculae lay near to the tooth germ in diverse regions, contacting the enamel surface in some areas, occasioning
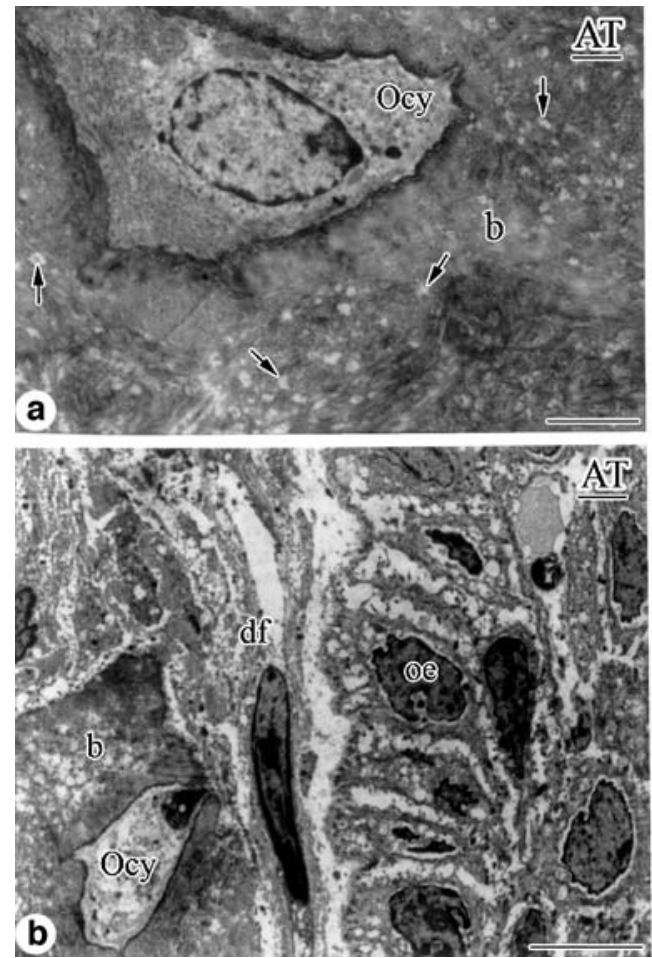

Fig. 5 Transmission electron micrographs showing areas of the bony crypt surrounding the tooth germs from alendronate-treated 14-dayold specimens. a An osteocyte $(O c y)$ is surrounded by the bone matrix (b) containing many interfibrillar spaces (arrows). Bar $2 \mu \mathrm{m}$. b Cervical portion of the developing tooth molar germ. A bone trabecula (b) containing an osteocyte $(O c y)$ appears to be in contact with the dental follicle cells $(d f)$, which are sandwiched between the invading bone and the outer epithelium of the enamel organ (oe). Bar $5 \mu \mathrm{m}$. c defects in the enamel. Several areas of ankylosis were observed (Fig. 2e). At this stage, no signals of bone resorption could be observed on the bony crypt, thereby offering no space for tooth germ volume growth and Hertwig's epithelial root sheath proliferation.

At day 30, the crown, root, and periodontal apparatus were completely formed (Fig. 2f), and molars had reached the occlusal plan in control specimens. The molars of alendronate-treated animals did not erupt. They remained surrounded by bone trabeculae almost in its entire extension, and several areas of ankylosis were observed. No deposition of root dentine or cementum occurred (Fig. 2g). The absence of bony crypt surface remodeling and the failure of the formation of the eruption pathway were associated with the defects in enamel that persisted in areas in which bone trabeculae contacted enamel (Fig. 2g,h).

\section{TRAP histochemistry}

All the trabeculae of bony crypt surrounding the developing molars were disorganized in alendronate-treated rats (Fig. 3). The presence of osteoclasts in the intertrabecular

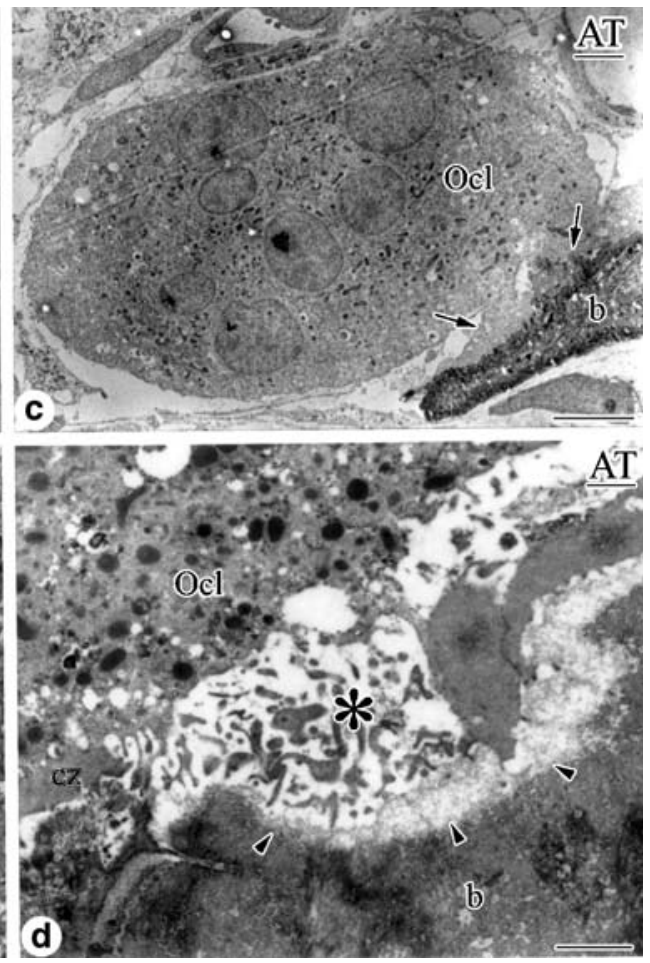

Portion of an intertrabecular region exhibiting a rounded osteoclast $(\mathrm{Ocl})$ apposed to the bone surface $(b)$ via a narrow foot-like projection consisting of a clear zone (arrows) with a small area corresponding to the ruffled border. Bar $10 \mu \mathrm{m}$. d One of the few cases in which these osteoclast projections $(\mathrm{Ocl})$ establish a more typical ruffled border (star) and clear zone $(c z)$ adjacent to a shallow resorbing concavity (arrowheads) on the bone surface (b). Bar $2 \mu \mathrm{m}$ 


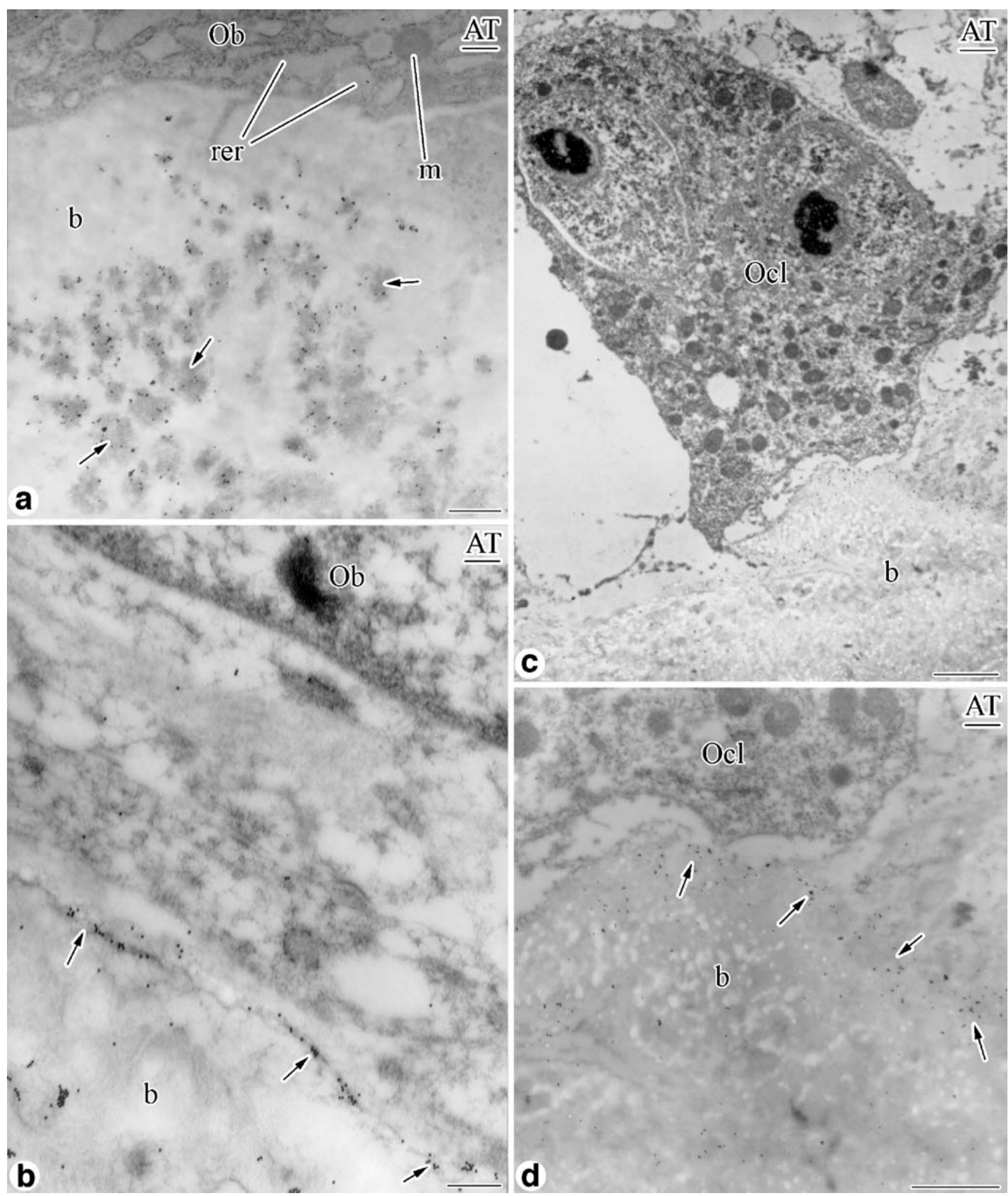

areas increased during the stages studied. These cells were round and contained several nuclei but did not adhere to bone surfaces (Fig. 3a). These osteoclasts were positive for TRAP (Fig. 3b).
Scanning electron microscopy

The upper first molar of 14-day animals exhibited a smooth enamel surface with a short length of dentine that probably 
4 Fig. 6 Electron micrographs showing immunocytochemical preparations for osteopontin (OPN) from alendronate-treated specimens. a Area of the developing bone surrounding a tooth germ from an alendronate-treated 4-day-old tooth not subjected to decalcification. A portion of an osteoblast $(\mathrm{Ob})$ with a mitochondrion $(\mathrm{m})$ and extensive rough endoplasmic reticulum (rer) lies adjacent to the early mineralizing bone matrix, which contains mineralizing globules immunoreactive for OPN (arrows). Bar $0.5 \mu \mathrm{m}$. b Region of bone trabecula (b) from an alendronate-treated 14-day-old specimen. The bone surface adjacent to an osteoblast $(\mathrm{Ob})$ contains gold particles (arrows). Bar $0.25 \mu \mathrm{m}$. c Region of the bone trabecula $(b)$ from an alendronatetreated 30-day-old specimen. A large multinucleated osteoclast $(\mathrm{Ocl})$ without a clear zone and ruffled border (revealing its latent stage) is seen adjacent to the bone matrix (b). Bar $3 \mu \mathrm{m}$. d Area of the bone surface intensely immunoreactive (arrows) for OPN and an adjacent osteoclast $(\mathrm{Ocl})$ at a higher magnification ( $b$ bone). Bar $1 \mu \mathrm{m}$

was covered by enamel matrix under mineralization (Fig. 4a). Alendronate-treated molars showed some morphological alterations in their enamel surface. Various depressions were detected along the entire enamel surface (Fig. 4b), and at the cervical portion, these alterations were more severe (Fig. 4c). The enamel depressions were localized at corresponding areas to those seen at the lightmicroscope level.

Control rats at 30 days of age presented the complete eruption of incisors and molars (Fig. 4d,e). A short length of the incisal portion of the incisor of alendronate-treated rats erupted (Fig. 4g), but the first molar appeared to be "locked inside" the crypt, and a communication with oral mucosa extending longitudinally in the occlusal area was present (Fig. 4f). Isolated molars of controls showed a smooth enamel surface, and their roots were almost completely formed (Fig. 4h). The enamel surface of alendronatetreated specimens was extensively altered, with many depression sites being present (Fig. 4i). The bone of fractured specimens exhibited several areas of ankylosis, and the bone trabeculae contacted the tooth germ at the sites corresponding to the depressions in the enamel, especially at the cervical portion (Fig. 4j). No root formation was found at any time point analyzed in alendronate-treated rats.

\section{Transmission electron microscopy}

Ultrastructural analysis confirmed the primary bone aspect of the trabeculae at the lateral walls of the bony crypt at all the stages studied after alendronate treatment. The primary bone aspect was recognized by the presence of many interfibrillar spaces in the mineralized matrix and by the irregular arrangement of the numerous osteocytes (Fig. 5a). The trabeculae invading the dental follicle established close contact with the outer epithelium of the enamel organ, in some cases compressing the dental follicle cells, which appeared sandwiched between the bone and the tooth germ (Fig. 5b). The latent osteoclasts present at the marrow spaces were round and located at some distance from the bone surface. However, occasional osteoclasts possessed a narrow foot-like projection that contacted the bone surface (Fig. $5 \mathrm{c}$ ). When examined at higher magnifications, these projections were seen to have established a resorbing region, constituted by a narrow ruffled border between two proportionally large areas of the peripheral clear zone. The bone surface of the portion subjacent to the narrow resorbing projections exhibited a shallow concavity (Fig. 5d).

\section{Immunolocalization of OPN}

Immunocytochemistry for OPN in alendronate-treated rats revealed intense labeling at the interfibrillar spaces of the alveolar bone at all the stages examined. Osteoblasts presented intracellular gold particles, which were located at the Golgi region (Fig. 6a). Most bone surfaces exhibited a lamina limitans labeled with gold particles (Fig. 6b). These were also present on the bone surfaces at which latent osteoclasts were apposed, even in situations in which they did not possess an active projection (Fig. 6c). All the cement lines were smooth revealing that they were from the appositional type, instead from the reversal type; these interfacial structures were intensely immunoreactive for this noncollagenous protein (Fig. 6d).

\section{Discussion}

The present study showed that sodium alendronate administered to rats from birth to 30 days of age impeded tooth eruption and root formation. The occlusal portion of the alveolar bony crypt did not resorb, and areas of ankylosis occurred between the alveolar bone and the developing hard dental tissues in all the alendronate-treated specimens. In addition, the alveolar bone of alendronate-treated specimens continued to have the structure of primary bone because of the lack of remodeling.

As expected, sodium alendronate impaired the resorption of alveolar bone because of its well-known anti-resorptive effect, and therefore, the eruption pathway was not established. This is the first report in which a bisphosphonate has been shown to impede tooth eruption, confirming that alendronate is a more potent resorption inhibitor than other bisphosphonates (van Beek et al. 2003), such as pamidronate, which only retards resorption. Indeed, Grier and Wise (1998) have detected delayed eruption of molars attributable to a low resorptive activity of osteoclasts, despite the finding that they exhibit a ruffled border and clear zone and are apposed to the bone surface. In this context, the administration of a more effective inhibitor of bone resorption improves the analysis of osteoclast activity in proportioning spatial conditions for tooth eruption. 
In general, the alveolar bone of alendronate-treated rats resembled osteopetrotic bone (Marks 1973). Indeed, the bony crypt trabeculae showed rare signals of resorption, despite the presence of numerous osteoclasts at the intertrabecular areas. These osteoclasts were large, round, multinucleated, and TRAP-positive cells, but most of them were located at a distance from the bone surface indicating they were osteoclasts that remained latent (Lerner 2000). Careful ultrastructural examination revealed, however, that some of them occasionally adhered to the bone matrix over a small area by means of a thin and short foot-like process (podosome) that culminated in a narrow ruffled border surrounded by a typical clear zone.

The presence of these cells suggests that all the molecules and factors of the signaling eruptive cascade (Wise et al. 2002) have been triggered and act in order to stimulate osteoclast formation, despite alendronate treatment. Activation of the newly fused osteoclasts, however, is severely retarded, since only a few cells are apposed to the bone surface. Although many factors have been proposed as possible initiators of tooth eruption, bone resorption at the occlusal surface of the bony crypt ultimately must take place before the opening of the eruption pathway. Moreover, the presence of OPN at the surface of bone trabeculae suggests that osteoclasts can attach to bone, since this protein is considered a ligand for the plasma membrane of the osteoclast clear zone (McKee and Nanci 1996). Boneapposed osteoclasts have been detected in adult alendronate-treated rats when parathyroid hormone-related protein (PTHrP) was administered to enhance resorptive activity (Sato et al. 1991).

Concomitant with the lack of bony crypt resorption, no root formation has been observed during the entire period of the present study of alendronate-treated rats. The contact of bone trabeculae with the Hertwig's epithelial root sheath and the epithelial diaphragm might have arrested root development, since these epithelial cells are believed to induce the differentiation of root odontoblasts by secreting specific molecules or factors (Zeichner-David et al. 2003; Janones et al. 2005). The presence of many ankylosis sites suggests that the resorption of bone at this region is a decisive event in triggering root formation, which occurs simultaneously with the displacement of tooth germ toward the oral cavity (Marks and Schroeder 1996). The contact of bone trabeculae with the developing tooth germ severely deforms the cervical enamel of the teeth of alendronatetreated rats during the entire period studied, from the early formation of coronal hard tissues until the age at which the teeth are supposed to be completely erupted. In general, contact between bone and epithelium is a rare phenomenon, even in developmental processes in which many events are rapid and sometimes transitional. To our knowledge, the only similar observation has been reported by Kitahara et al. $(2002,2004)$ in an experimental model consisting of PTHrP-knockout mice at embryonic stages. Interestingly, the invasion of bone trabeculae into epithelial cells affects the formation of root dentine and cementum but not that of coronal dentine and enamel, as shown previously (Massa et al. 2006). In the crown, the bone invasion at the cervical area of the tooth germ occurs after epithelial-ectomesenchymal inductive events, whereas Hertwig's epithelial root sheath cells are disrupted by the ankylosis of bone trabeculae. Thus, unlike the events that occur in the crown portion, root development requires not only the induction of dental papilla cells, but also the continuous proliferation of Hertwig's epithelial root sheath.

The results of the present study also allow the discussion of some aspects regarding the role of the dental follicle in tooth eruption. Previous experiments have shown the absence of tooth eruption in dogs after removal of their dental follicle (Cahill and Marks 1980), indicating that it plays a key role in initiating tooth eruption (Wise et al. 2002). The invasion of bone trabeculae toward the tooth germ certainly disrupts dental follicle homeostasis and might interfere with the releasing of factors responsible for triggering bone resorption at the occlusal portion of the crypt wall.

Of note, alendronate treatment not only impedes the opening of the eruption pathway, but also prevents bone remodeling of the primary bone into secondary or lamellar bone. Although osteogenesis in rat maxilla and mandible begins on the 17th intrauterine day, the first osteoclasts only appear at the day of birth (Strong 1925), i.e., when we start alendronate treatment. The lack of bone remodeling yields 30-day-old animals in which alveolar processes are formed by trabeculae that still exhibit features of primary bone, with its characteristic immunolabeling for OPN.

Bisphosphonates, including sodium alendronate, are the mainstay of treatment of adult bone diseases such as postmenopausal osteoporosis (McClung 2003; Greenblatt 2005), cancer chemotherapy, the prevention of malignant tumor bone metastasis (Santini et al. 2003; Muller at al. 2005), and bone pain caused by radiotherapy (Lussier et al. 2004). Since this drug is also indicated in the therapy of several pediatric bone disorders (Maasalu et al. 2003; Ward et al. 2005), it is possible that alendronate administration to children or adolescents in which odontogenesis and/or tooth eruption are taking place might induce the structural alteration of teeth or even the failure of tooth eruption. Furthermore, the lack of bone remodeling might promote a number of abnormalities during skeletal growth.

In summary, the lack of tooth eruption and of root formation, the occurrence of ankylosis, and the injuries to the epithelium and dental follicle observed in alendronatetreated rats could be the result of the arrest of bone remodeling that thereby disrupts the necessary dynamic 
relationship between the dental and periodontal tissues involved in tooth eruption.

Acknowledgements The authors thank Dr. Antonio Nanci (University of Montreal, Canada) for supplying the anti-rat OPN antibody, and Dr. Lucienne Bonafe-Oliveira for her help during the histochemical procedures. Technical assistance by Mrs. Fernanda Barrence and Mr. Gerson B. Silva (in memoriam), ultrathin sectioning by $\mathrm{Mr}$. Gaspar F. de Lima, and production of electron micrographs by Mr. Edson Oliveira are also gratefully acknowledged.

\section{References}

Arana-Chavez VE, Nanci A (2001) High-resolution immunocytochemistry of noncollagenous matrix proteins in rat mandibles processed with microwave irradiation. J Histochem Cytochem 49:1099-1110

Bonafe-Oliveira L, Faltin RM, Arana-Chavez VE (2003) Ultrastructural and histochemical examination of alveolar bone at the pressure areas of rat molars submitted to continuous orthodontic force. Eur J Oral Sci 111:410-416

Cahill DR, Marks SC Jr (1980) Tooth eruption: evidence for the central role of the dental follicle. J Oral Pathol 9:189-200

Greenblatt D (2005) Treatment of postmenopausal osteoporosis. Pharmacotherapy 25:574-584

Grier RL, Wise GE (1998) Inhibition of tooth eruption in the rat by a bisphosphonate. J Dent Res 77:8-15

Halasy-Nagy JM, Rodan GA, Reszka AA (2001) Inhibition of bone resorption by alendronate and risedronate does not require osteoclast apoptosis. Bone 29:553-559

Janones DS, Massa LF, Arana-Chavez VE (2005) Immunocytochemical examination of the presence of amelogenin during the root development of rat molars. Arch Oral Biol 50:527-532

Kitahara Y, Suda N, Kuroda T, Beck F, Hammond VE, Takano Y (2002) Disturbed tooth development in parathyroid hormonerelated protein (PTHrP)-gene knockout mice. Bone 30:48-56

Kitahara Y, Suda N, Terashima T, Baba O, Mekaapiruk K, Hammond VE, Takano Y, Ohyama K (2004) Accelerated bone formation and increased osteoblast number contribute to the abnormal tooth germ development in parathyroid hormone-related protein knockout mice. Bone 35:1100-1106

Lerner UH (2000) Osteoclast formation and resorption. Matrix Biol 19: $107-120$

Lussier D, Huskey AG, Portenoy RK (2004) Adjuvant analgesics in cancer pain management. Oncologist 9:571-591

Maasalu K, Haviko T, Martson A (2003) Treatment of children with osteogenesis imperfecta in Estonia. Acta Paediatr 92:452-455

Marks SC Jr (1973) Pathogenesis of osteopetrosis in the IA rat: reduced bone resorption due to reduced osteoclast function. Am J Anat 138:165-189
Marks SC Jr, Schroeder HE (1996) Tooth eruption: theories and facts. Anat Rec 245:374-393

Massa LF, Arana-Chavez VE (2000) Ultrastructural preservation of rat embryonic dental tissues after rapid fixation and dehydratation under microwave irradiation. Eur J Oral Sci 108:74-77

Massa LF, Bradaschia-Correa V, Arana-Chavez VE (2006) Immunocytochemical study of amelogenin deposition during the early odontogenesis of molars in alendronate-treated newborn rats. J Histochem Cytochem 54:713-725

McClung M (2003) Use of highly potent bisphosphonates in the treatment of osteoporosis. Curr Osteoporos Rep 1:116-122

McKee MD, Nanci A (1996) Osteopontin: an interfacial extracellular matrix protein in mineralized tissues. Connect Tissue Res 35:197-205

Muller S, Migianu E, Lecouvey M, Kraemer M, Oudar O (2005) Alendronate inhibits proliferation and invasion of human epidermoid carcinoma cells in vitro. Anticancer Res 25:26552660

Nanci A (1999) Content and distribution of noncollagenous matrix proteins in bone and cementum: relationship to speed of formation and collagen packing density. J Struct Biol 126:256-269

Nanci A, Zalzal S, Gotoh Y, McKee MD (1996) Ultrastructural characterization and immunolocalization of osteopontin in rat calvarial osteoblast primary cultures. Microsc Res Tech 33:214-231

Rogers MJ, Gordon S, Benford HL, Coxon FP, Luckman SP, Monkkonen J, Frith JC (2000) Cellular and molecular mechanisms of action of bisphosphonates. Cancer 88:2961-2978

Santini D, Gentilucci UV, Vicenzi B, Picardi A, Vasaturo F, La Cesa A, Onori N, Scarpa S, Tonini G (2003) The antineoplastic role of bisphosphonates: from basic research to clinical evidence. Ann Oncol 14:1468-1476

Sato M, Grasser W, Endo N, Akins R, Simmons H, Thompson DD, Golub E, Rodan GA (1991) Bisphosphonate action-alendronate localization in rat bone and effects on osteoclast ultrastructure. J Clin Invest 88:2095-2105

Srivastava T, Alon US (2003) The role of bisphosphonates in diseases of childhood. Eur J Pediatr 162:735-751

Strong RM (1925) The order, time, and rate of ossification of the albino rat (Mus novergicus albinos) skeleton. Am J Anat 36: 313-355

van Beek ER, Cohen LH, Leroy IM, Ebetino FH, Löwik CWGM, Papapoulos SE (2003) Differentiating the mechanisms of resorptive action of nitrogen containing bisphosphonates. Bone $33: 805-811$

Vasikaran SD (2001) Bisphosphonates: an overview with special reference to alendronate. Ann Clin Biochem 38:608-623

Ward K, Cowell CT, Little DG (2005) Quantification of metaphyseal modeling in children treated with bisphosphonates. Bone 36:999-1002

Wise GE, Frazier-Bowers S, D'Souza RN (2002) Cellular, molecular and genetic determinants of tooth eruption. Crit Rev Oral Biol Med 13:323-334

Zeichner-David M, Oishi K, Su Z, Chen IS, Arzate H, Bringas P (2003) Role of Hertwig's epithelial root sheath cells in tooth root development. Dev Dyn 228:651-663 
ANEXO 2 


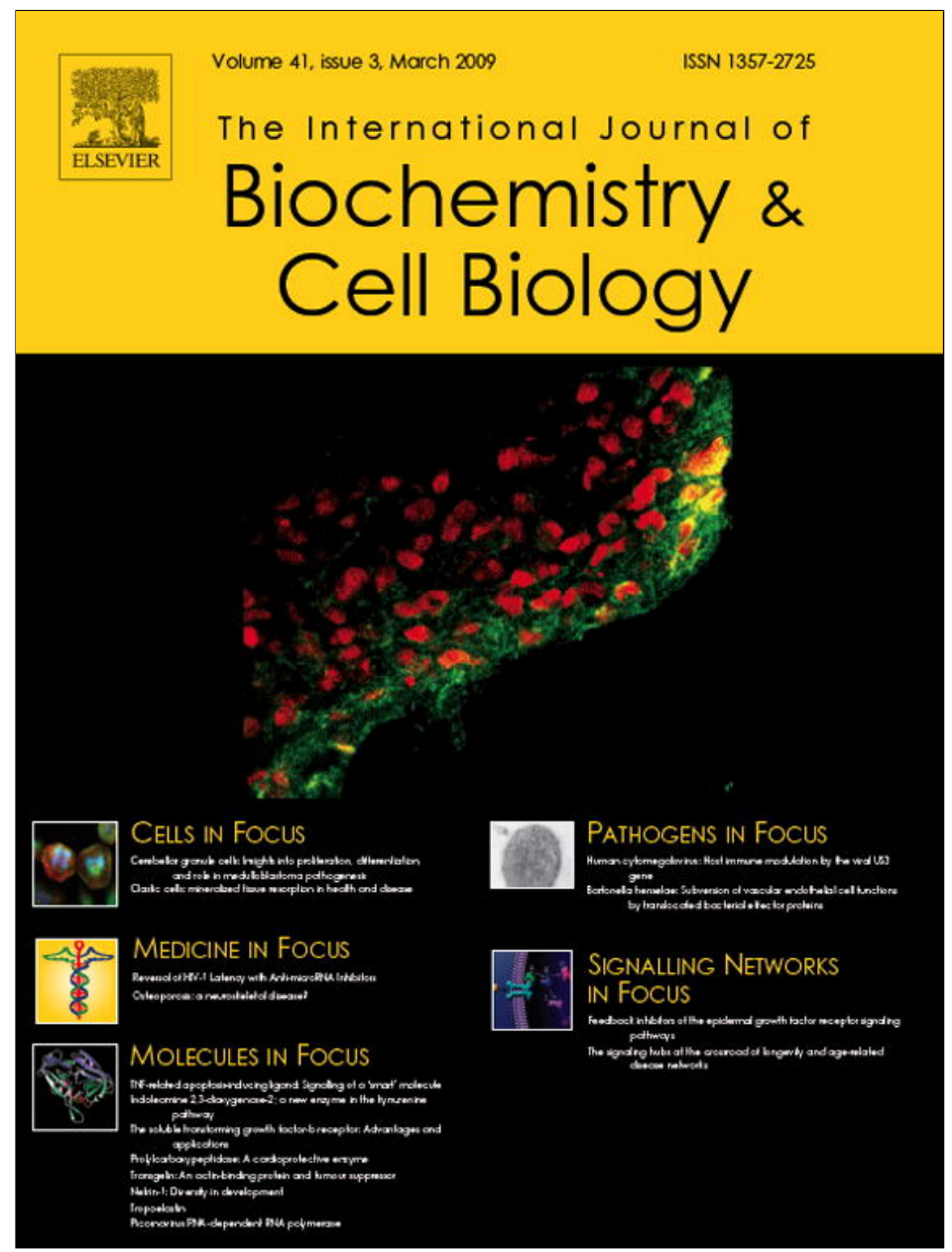

This article appeared in a journal published by Elsevier. The attached copy is furnished to the author for internal non-commercial research and education use, including for instruction at the authors institution and sharing with colleagues.

Other uses, including reproduction and distribution, or selling or licensing copies, or posting to personal, institutional or third party websites are prohibited.

In most cases authors are permitted to post their version of the article (e.g. in Word or Tex form) to their personal website or institutional repository. Authors requiring further information regarding Elsevier's archiving and manuscript policies are encouraged to visit: 
Cells in focus

\title{
Clastic cells: Mineralized tissue resorption in health and disease
}

\author{
Victor E. Arana-Chavez*, Vivian Bradaschia-Correa \\ Laboratory of Mineralized Tissue Biology, Department of Cell and Developmental Biology, Institute of Biomedical Sciences, \\ University of São Paulo, 05508-900 São Paulo, SP, Brazil
}

\section{A R T I C L E I N F O}

\section{Article history:}

Received 18 June 2008

Received in revised form 28 August 2008

Accepted 8 September 2008

Available online 19 September 2008

\section{Keywords:}

Clastic cells

Osteoclast

Odontoclast

Resorption

\begin{abstract}
A B S T R A C T
Clastic cells are responsible for mineralized tissue resorption. Bone resorbing cells are called osteoclasts; however, they are able to resorb mineralized dental tissues or calcified cartilage and then they are called odontoclasts and chondroclasts, respectively. They derive from mononuclear precursors of the monocyte-macrophage lineage from hemopoietic tissue, reach target mineralized tissues and degrade them under many different physiologic or pathologic stimuli. Clastic cells play a key role in calcium homeostasis, and participate in skeletal growth, tooth movement, and other physiological and pathological events. They interact tightly with forming cells in bone and dental hard tissues; their unbalance may result in disturbed resorptive activity thus, causing local or systemic diseases.
\end{abstract}

(C) 2008 Elsevier Ltd. All rights reserved.

\section{Cell facts}

- Clastic cells may resorb all mineralized tissues in the body.

- Clastic cells derive from the monocyte-macrophage lineage.

- Clastic cells present different stages of activity depending on stimulus.

\section{Introduction}

Clastic cells are responsible for the resorption of mineralized matrix of hard tissues. Although firstly described as osteoclasts, they are able to resorb mineralized dental tissues and calcified cartilage, where they are called odontoclasts and chondroclasts, respectively. In that sense, although osteoclasts are the best studied mineralized tissue resorbing cells, odontoclasts and chondroclasts belong to the same cell type and therefore in this article they are called clastic cells.

Clastic cells form when mononuclear precursors derived from a monocyte-macrophage cell lineage are attracted to certain mineralized surfaces and subsequently fuse and adhere onto them for exerting their resorbing activity. These cells present different functional stages, remaining latent or active (Lerner, 2000). The activity

\footnotetext{
* Corresponding author. Tel.: +55 113091 7308; fax: +55 1130917402 .

E-mail address: vearana@usp.br (V.E. Arana-Chavez).
}

of these cells can be observed in both physiological and pathological phenomena throughout life.

Functional clastic cells are responsible for degradation of calcified extracellular matrix composed of organic molecules and hydroxyapatite. This process is mainly required in bone turnover and growth, spontaneous and induced (orthodontic) tooth movement, tooth eruption, and bone fracture healing, as well as in pathological conditions such as osteoporosis, osteoarthritis, and bone metastasis. In addition, they are responsible for daily control of calcium homeostasis. Clastic cells also resorb the primary teeth for shedding before the permanent teeth erupt into the oral cavity.

\section{Cell origin and activation}

Pluripotent hemopoietic stem cells rise into myeloid stem cells, which are capable of proliferating and differentiating into the leukocyte family of blood cells, i.e., megakaryocytes, granulocytes, monocyte-macrophages and also into clastic cells (Lerner, 2000). The earliest precursor of clastic cells identifiable from hemopoietic tissue is the granulocyte-macrophage colony-forming cell (CFUGM) (Roodman, 2006). The recruitment of clastic cell precursors involves complex interactions between osteoblasts, stromal bone marrow cells and hemopoietic cells. Although cellular and molecular phenomena that occur in clastic cell formation are currently well known, some gaps in the exact sequence of events involved in the whole process remain unsolved.

The precursors of clastic cells are responsive to growth factors secreted by several types of mesenchymal cells, depending on the biological process, condition and localization. For exam- 
ple, interleukin-3 (IL-3) and macrophage-colony stimulating factor (M-CSF) are secreted by stromal cells of bone marrow and bind to receptors in membrane of the postmitotic precursors cells, which proliferate and differentiate into committed pre-osteoclasts (Roodman, 2006). Clastic cells become multinucleated by fusion of numerous committed mononuclear precursors. There are evidences that some proteins and glycoconjugates of the plasma membrane are involved in this process. Although molecules such as e-cadherin, macrophage fusion receptor, ADAM9, CD98, P2X7 receptor, CD9 and alpha (2,6)-linked-sialic acid had been described as components of cell-cell fusion process in osteoclast differentiation, their exact functions in the process are not completely understood (Takahata et al., 2007).

The activation of fused clastic cells is regulated by activation of the receptor activator of NF-kB (RANK), expressed in plasma membrane of precursors and fused clastic cells; its ligand (RANKL), a soluble protein secreted by osteoblasts and their precursors in bone, binds to RANK and stimulates differentiation and signaling pathways in clastic cell precursors. RANKL expression is induced by $1 \alpha, 25(\mathrm{OH})_{2} \mathrm{D} 3$, parathyroid hormone, prostaglandins and $\mathrm{M}-\mathrm{CSF}$ (Yasuda et al., 1998). The antagonist of RANKL is osteoprotegerin (OPG), a soluble protein that is also secreted by osteoblasts. Binding of OPG to RANKL inhibits the genesis of clastic cells, thus preventing the RANKL linkage to RANK (Tanaka et al., 2003). Fig. 1A illustrates the mechanisms of osteoclastogenesis.

After differentiation and activation, rearrangement of cytoskeleton of clastic cells and therefore their attachment to bone mineralized matrix is regulated by the intracellular c-Src protein; loss of c-Src results in latent clastic cells (Miyazaki-Sanjay et al., 2004). In addition, gap junctions established between clastic cell and osteoblasts/stromal cells appear to play an essential role in the genesis of clastic cells by the establishment of a pathway for cellular crosstalk and diffusion of messenger molecules that interact with signaling pathway downstream RANKL in clastic cell differentiation (Matemba et al., 2006). Peripheral inervation and intrinsic neurotransmitter-like signaling in the bone microenvironment are able to influence the differentiation and activity of osteoblasts and clastic cells and the regulation of the bone remodeling cycle. Neurotransmitters and neuromodulators have been also considered to regulate bone remodeling by mechanism attributed to the excitatory amino acid glutamate (Spencer et al., 2007).

The concept of osteoimmunology has recently emerged due to the intimate relationship between immune system and the skeleton. As RANKL is also expressed by activated T cells, it is likely that this molecule is important in both the skeletal and immune systems. The bone loss in autoimmune arthritis occurs due to a defective control of bone metabolism by the immune system, where T-cell mediated regulation of osteoclast formation takes place through a signaling crosstalk between RANKL and interferon $\gamma$ (IFN $\gamma$ ). These findings contribute to understanding the pathogenesis and developing new therapeutic strategies for diseases affecting both skeletal and immune systems (Takayanagi, 2005).

Clastic cells also resorb dental hard tissues; in these situations they are named odontoclasts. Recruitment of precursors as well as the structure and function of clastic cells follow the characteristics discussed above. A particularity is that clastic cells resorbing dentine from roots of primary (deciduous) teeth before shedding are frequently mononuclear (Domon et al., 2001). In orthodontic movement, alveolar bone and dental root resorption are mediated by inflammatory reaction. Periodontal ligament is compressed by the orthodontic force applied that yields a region of hyalinization in which aseptic necrosis takes place. After macrophages remove the hyalinized area, the adjacent alveolar bone is resorbed by recruited and activated clastic cells. Although only alveolar bone should be resorbed, the resorption of root surface is an undesirable side effect that frequently occurs during orthodontic treatment depending on type and/or magnitude of applied force (Casa et al., 2006).

\section{Cell structure and function}

Once clastic cell precursors are fused and activated, polarization events take place by rearrangement of the cytoskeleton and formation of the sealing zone. The activated clastic cell present four different specialized membrane domains: the sealing zone and ruffled border that face the bone matrix, the basolateral domain and the functional secretory domain, which are not in contact with the bone matrix but with the extracellular fluid and other cells (Mulari et al., 2003). Fig. 1B illustrates the osteoclast structure and function.

As they differentiate into multinucleated cells, the sealing zone that encircles the plasma membrane develops unique form of matrix adhesions known as podosomes. Ultrastructuraly, this portion of the cell does not present organelles, and its clear aspect originated the denomination "clear zone" (Fig. 2A and B). These structures consist of an actin "ring" enriched in $\alpha v \beta 3$ integrin and plaque proteins, classically found in focal adhesions, including vinculin, paxillin, talin, tensin and actin-associated proteins such as $\alpha$-actinin, fimbrin, gelsolin, cortactin and dynamin. The $\alpha v \beta 3$ integrin binds to the RGD sequence of noncollagenous bone matrix proteins such as vitronectin, osteopontin, and bone sialoprotein (Luxemburg et al., 2006).

The ruffled border formed by the fusion of intracellular acidic compartments to the bone-facing plasma membrane at the early phase of the resorption cycle is responsible for the resorptive activity of clastic cells. Endosomal vesicles fuse to the plasma membrane and then release substances that degrade inorganic and organic matrix components. The membrane fusion takes place at the peripheral ruffled border, while uptake of degraded matrix occurs at its central portion.

The dissolution of hydroxyapatite crystals occurs due to acidification in the resorption lacuna. The low $\mathrm{pH}$ is created by a vacuolar type proton pump ATPase (V-ATPase) and chloride channels in the ruffled border. The V-ATPase originates from cytosolic compartments to the ruffled plasma membrane of osteoclasts as they activate to resorb bone (Holliday et al., 2005). The protons released by the proton pump are generated by induction of carbonic anhydrase II. Regulation and balancing of intracellular $\mathrm{pH}$ during acid secretion is maintained by a $\mathrm{HCO}_{3}{ }^{-} / \mathrm{Cl}^{-}$exchanger located at the basolateral membrane. This structure transports the excess of intracellular $\mathrm{HCO}_{3}-$ ions outside the cells thus, preventing intracellular alkalinization, while importing chloride ions inside the cell for secretion to the resorption lacuna (Mulari et al., 2003).

Once the mineral is dissolved, the organic phase is exposed to proteolytic enzymes synthesized and secreted by the clastic cell into the resorbing lacuna. This process involves participation of different enzymes, e.g., cysteine proteinases, matrix metalloproteinases (MMPs), serine proteinases and tartrate-resistant acid phosphatase (TRAP) (Delaissé et al., 2003). The degradation products are uptaken by the clastic cell in the resorption site, and vesicles containing organic and inorganic material are transported to the functional secretory domain at the plasma membrane. This mechanism allows these cells to maintain resorptive activity throughout their active life-span without accumulation of degradation products in the Howship's lacuna (Mulari et al., 2003).

\section{Associated pathologies}

After the completion of skeletal growth, bone health is maintained by the coupled processes of bone resorption and bone formation, together called bone remodeling. At least one million of 
(A)

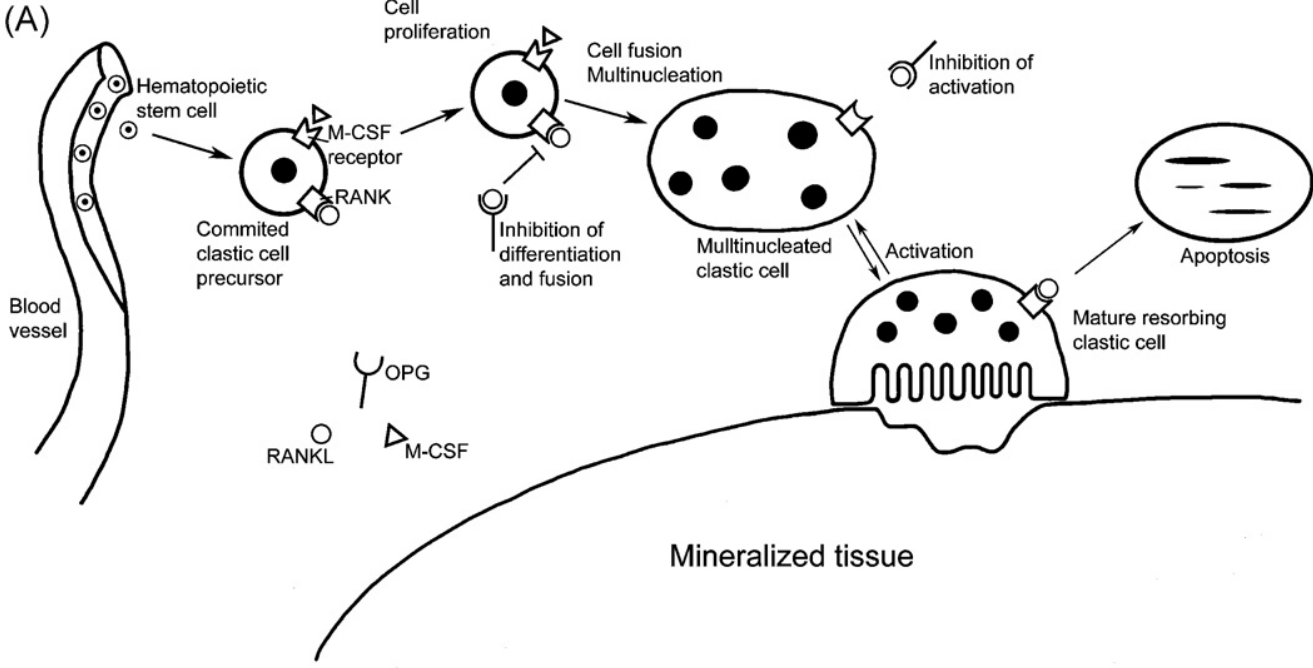

(B)

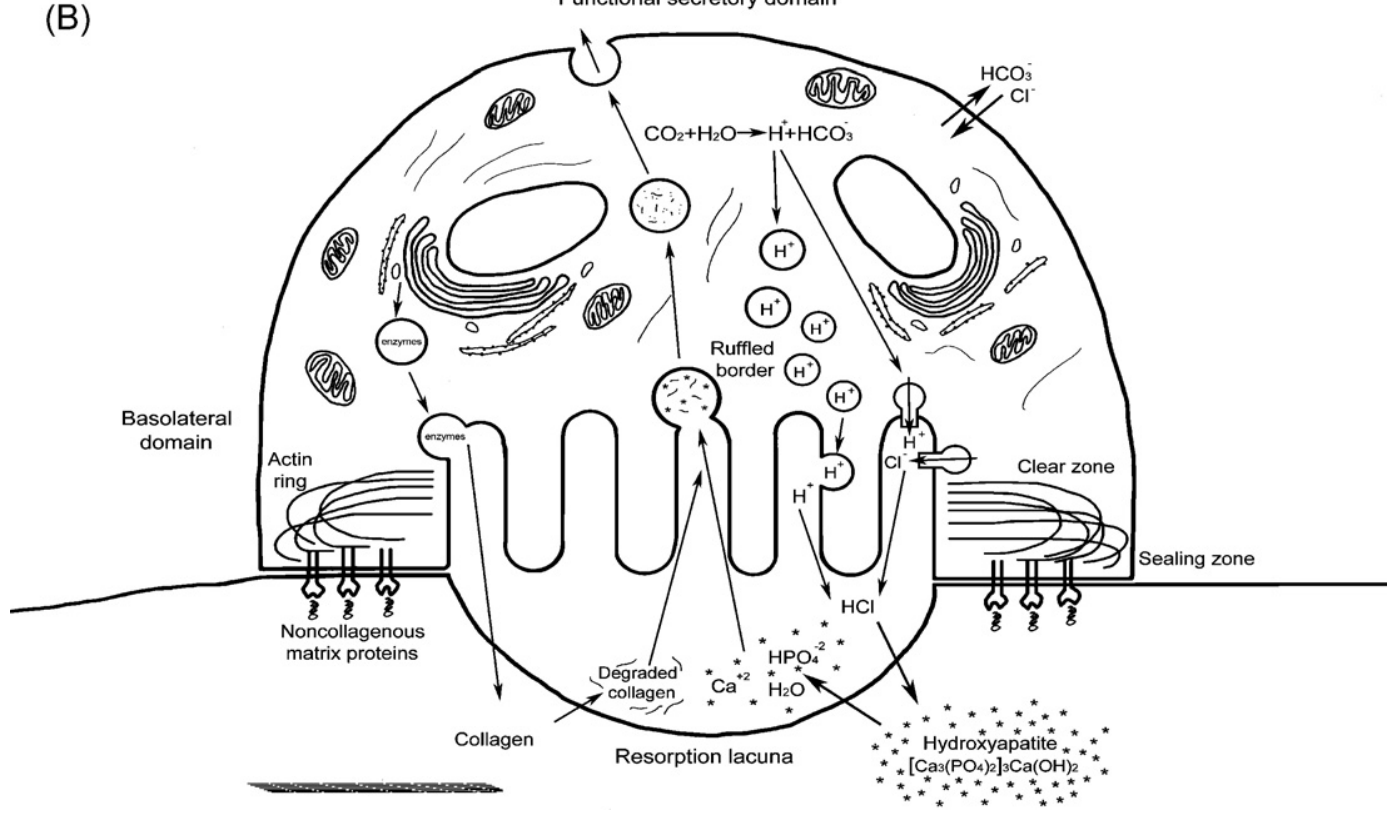

Fig. 1. (A) A schematic drawing showing the recruitment and activation mechanisms of clastic cells. Hematopoietic precursors are attracted from blood circulation into a resorbing area. RANKL and M-CSF bind to RANK and M-CSF receptor becoming committed clastic precursors, which proliferate and fuse into multinucleated cells. Activation of the multinucleated cell occurs in response to RANKL, reaching the state of a mature resorbing clastic cell. Differentiation, fusion and activation can be inhibited by OPG-RANKL binding. (B) A diagram of an active clastic cell apposed to a mineralized tissue. Protons are supplied by hydration of $\mathrm{CO}_{2}$, which are pumped to the resorption lacuna. The $\mathrm{HCO}_{3}-$ produced during $\mathrm{CO}_{2}$ hydration is exchanged for chloride ions at the basolateral cell domain, which are transferred to the resorption lacuna through a chloride channel. $\mathrm{HCl}$ decreases the $\mathrm{pH}$ thus, dissolving the hydroxyapatite, while enzymes exocytosed degrade the organic matrix components. Degradation products are then endocytosed at the ruffled border membrane and transported to the functional secretory domain.

microscopic remodeling foci are present at any one time in the adult skeleton (Boyce and Xing, 2007). Old or damaged bone is removed and replaced by healthy bone. In young adults these processes are balanced, and skeletal renewal occurs without significant change in bone mass. However, various diseases, drugs, and metabolic abnormalities adversely affect bone health, culminating in skeletal disorders mainly due to defects in osteoclast function or formation. The mainly known defects are lack of acid secretion, proteinase deficiency and disturbs in OPG and RANK signaling (Helfrich, 2003).

Osteopetrosis is characterized by a general increase in bone mass, associated with the presence of normal or increased number of osteoclasts. Other clinical features are bone sclerosis (resulting in pathological fractures), renal tubular acidosis, cerebral calcifications and cranial nerve compressions. Histologically, osteoclasts remain as unpolarized cells, which therefore have no ruffled border and do not secrete acids. The disturbances of these cells can occur due to genetic defect in vacuolar ATPase, deficiency in carbonic anhydrase II, and deletion of signaling molecules such as M-CSF and components of NFkB signaling pathway. As a result, osteopetrotic bone exhibits an unremodeled appearance (Helfrich, 2003).

The middle-age Paget's disease of bone (PDB) occasion enlargement and softening of bone due to a mutation in RANK that is responsible for the osteoclast hyperactivity (Helfrich, 2003). Another type, the juvenile PDB, is associated to deletion or mutation of the gene encoding OPG, and results in severe systemic high-turnover osteoporosis. Some components of ubiquitylation during RANK-signaling pathway in osteoclasts are mutated, resulting in increased sensitivity of these cells to the cytokines above mentioned (Layfield and Shaw, 2007). Clinically, long bones and extremities, pelvis and skull are affected most, becoming curved; 

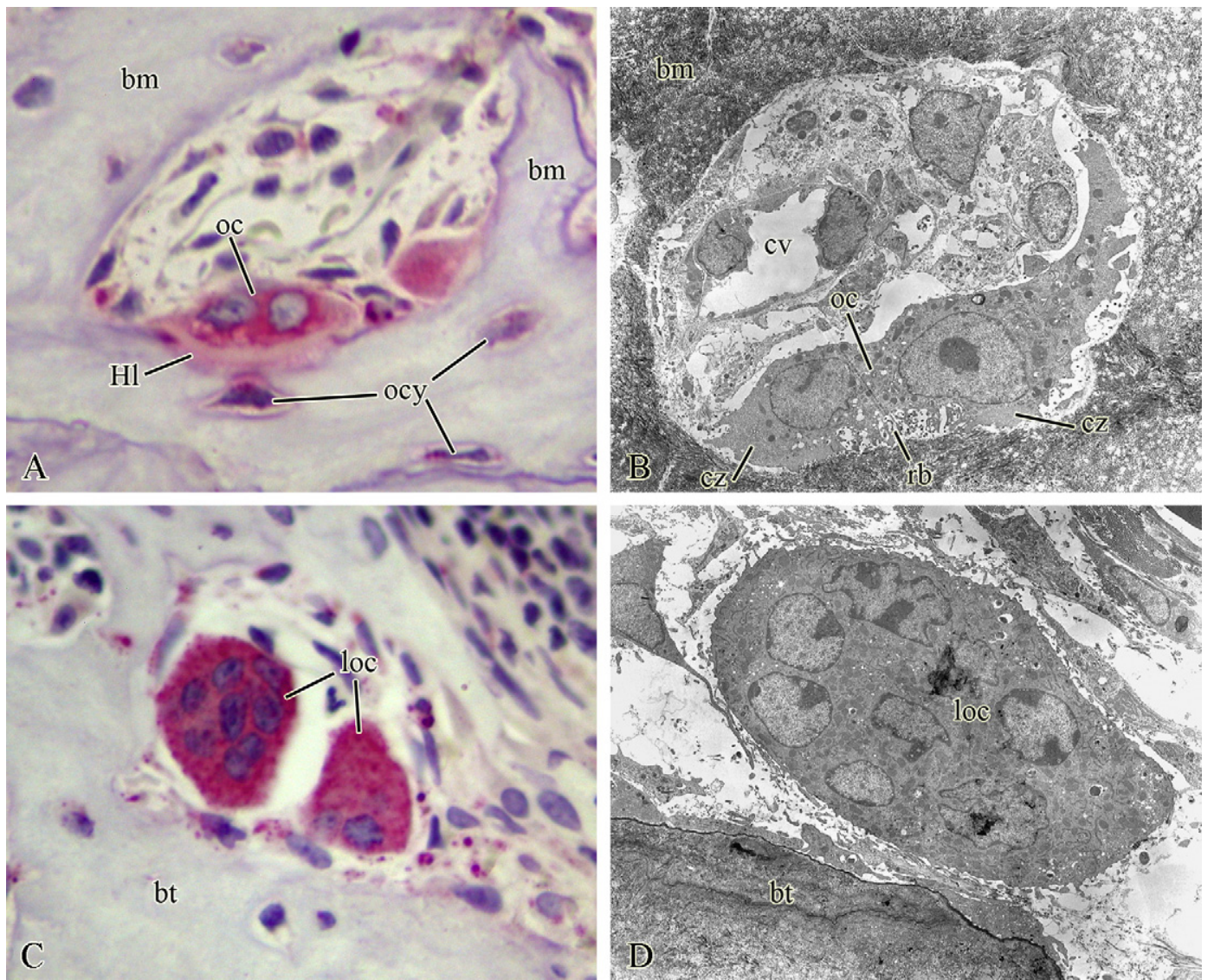

Fig. 2. A. Light micrograph showing an active TRAP-positive clastic cell apposed to the bone matrix (bm), thus being an osteoclast (oc). The resorbing bone surface that is called Howship's lacuna ( $\mathrm{Hl}$ ) is almost reaching an osteocyte (osteoblast buried in the bone mineralized matrix) (ocy). Hematoxylin counterstaining: $250 \times$. B: Transmission electron micrograph of an active osteoclast (oc) inside a Haversian canal displaying typical clear zone (cz) and ruffled border (rb). cv, capillary vessel: $2100 \times$. C. Light micrograph illustrating two round latent TRAP-positive osteoclasts (loc), next to a bone trabecula (bt). Hematoxylin counterstaining: $200 \times$. D. Transmission electron micrograph of a latent osteoclast $(\mathrm{loc})$ loose in the bone marrow space. Note several nuclei with condensed chromatin and the absence of clear zone and ruffled border: $2300 \times$.

bone pain, deafness and pathological fractures are important symptoms.

In osteoporosis, the main bone disorder nowadays, bone resorption is higher than formation yielding skeletal fragility that increases fracture risk. Clinically, it is characterized by a decrease in bone mineral density. Antiresorptive drugs as bisphosphonates effectively prevent bone loss in both postmenopausal women without osteoporosis and preserve or improve bone mass and substantially reduce fracture risk in postmenopausal women and men with osteoporosis. In fact, they may interfere at fusion of clastic cell precursors or later on activation and function of formed clastic cells. Alendronate, for example, inactivate the fused clastic cells (Bradaschia-Correa et al., 2007), which are unable to bind to mineralized surfaces thus, remaining latent (Fig. 2C and D).

Besides the bone pathologies above, abnormal osteoclast activity also plays a role in bone metastasis of tumors. Indeed, oncogenic cells producing osteolytic or mixed osteolytic/osteoblastic lesions in metastic bone diseases have been shown to secrete soluble RANKL (Michigami et al., 2001).

\section{Acknowledgements}

The authors thank technical assistance by Fernanda Barrence, Gerson Silva (in memoriam), and Gaspar Lima. Fapesp and CNPq (Brazil) are acknowledged by their financial support.

\section{References}

Boyce BF, Xing L. Biology of RANK, RANKL, and osteoprotegerin. Arthritis Res Ther 2007:9(Suppl. 1):S1.

Bradaschia-Correa V, Massa LF, Arana-Chavez VE. Effects of alendronate on tooth eruption and molar root formation in young growing rats. Cell Tissue Res 2007;330:475-85.

Casa MA, Faltin RM, Faltin K, Arana-Chavez VE. Root resorption on torqued human premolars shown by tartrate-resistant acid phosphatase histochemistry and transmission electron microscopy. Angle Orthod 2006;76:1015-21.

Delaissé J-M, Andersen TL, Engsig MT, Henriksen K, Troen T, Blavier L. Matrix metalloproteinases (MMP) and cathepsin K contribute differently to osteoclast activities. Microsc Res Tech 2003;61:504-13.

Domon T, Suzuki R, Takata K, Yamazaki Y, Takahashi S, Yamamoto T, et al. The nature and function of mononuclear cells on the resorbed surfaces of bone in the reversal phase during remodeling. Ann Anat 2001;183:103-10.

Helfrich MH. Osteoclast diseases. Microsc Res Tech 2003;61:514-32.

Holliday LS, Bubb MR, Jiang J, Hurst IR, Zuo J. Interactions between vacuolar $\mathrm{H}^{+}$-ATPases and microfilaments in osteoclasts. J Bioenerg Biomembr 2005;37:419-23.

Layfield R, Shaw B. Ubiquitin-mediated signalling and Paget's disease of bone. BMC Biochem 2007;8(Suppl. 1):S5.

Lerner UH. Osteoclast formation and resorption. Matrix Biol 2000;19:107-20.

Luxemburg C, Addadi L, Geiger B. The molecular dynamics of osteoclast adhesions. Eur J Cell Biol 2006;85:203-11.

Matemba SF, Lie A, Ransjö M. Regulation of osteoclastogenesis by gap junction communication. J Cell Biochem 2006;99:528-37.

Michigami T, Ihara-Watanabe M, Yamazaki M, Ozono K. Receptor activator of nuclear factor kappaB ligand (RANKL) is a key molecule of osteoclast formation for bone metastasis in a newly developed model of human neuroblastoma. Cancer Res 2001;61:1637-44.

Miyazaki-Sanjay A, Neff L, Tanaka S, Horne WC, Baron R. Src kinase activity is essential for osteoclast function. J Biol Chem 2004;279:17660-6.

Mulari M, Vääräniemi J, Väänänen HK. Intracellular membrane trafficking in bone resorbing osteoclasts. Microsc Res Tech 2003;61:496-503. 
Roodman GD. Regulation of osteoclast differentiation. Ann N Y Acad Sci 2006;1068:100-9.

Spencer GJ, McGrath CJ, Genever PG. Current perspectives on NMDA-type glutamate signaling in bone. Int J Biochem Cell Biol 2007;39:1089-104.

Takahata M, Iwasaki N, Nakagawa H, Abe Y, Watanabe T, Ito M, et al. Sialylation of cell surface glycoconjugates is essential for osteoclastogenesis. Bone 2007;41:77-86.

Takayanagi H. Mechanistic insight into osteoclast differentiation in osteoimmunology. J Mol Med 2005;83:170-9.
Tanaka S, Nakamura I, Inoue J-I, Oda $\mathrm{H}$, Nakamura K. Signal transduction pathways regulating osteoclast differentiation and function. J Bone Miner Metab 2003;21:123-33.

Yasuda H, Shima N, Nakagawa N, Yamaguchi K, Kinosaki M, Mochizuki S, et al. Osteoclast differentiation factor is a ligand for osteoprotegerin/osteoclastogenesisinhibitory factor and is identical to TRANCE/RANKL. Proc Natl Acad Sci USA 1998;95:3597-602. 